Prepared in cooperation with the Summit Water Quality Committee

\title{
Analysis of Water Quality in the Blue River Watershed, Colorado, 1984 through 2007
}

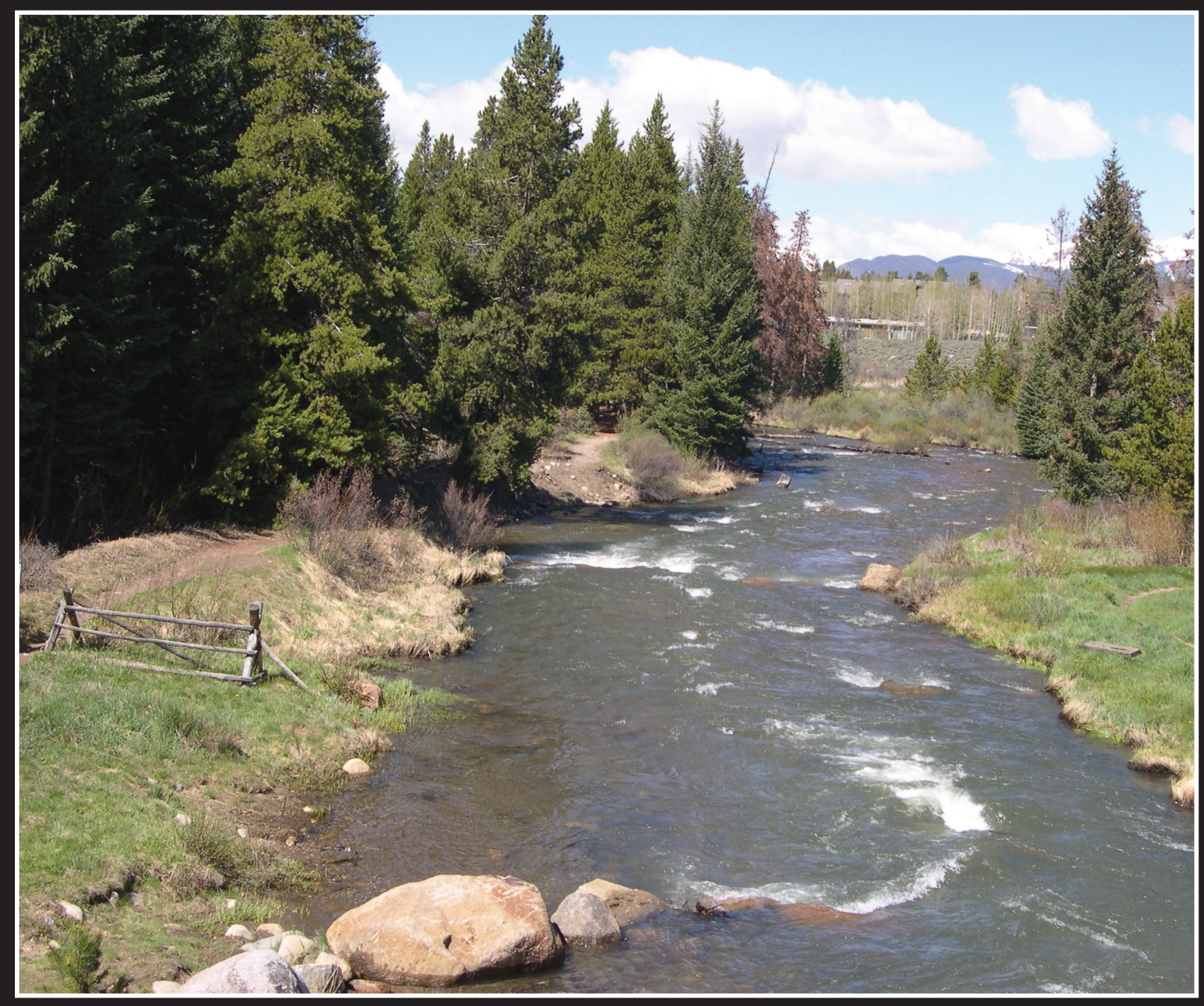

Scientific Investigations Report 2013-5129 
Front cover. Snake River at Keystone, Colorado, looking downstream, May 27, 2009. Photograph by Nancy J. Bauch, U.S. Geological Survey.

Back cover. Dillon Reservoir at Dillon, Colorado, May 27, 2009.

Photograph by Nancy J. Bauch, U.S. Geological Survey. 


\section{Analysis of Water Quality in the Blue River Watershed, Colorado, 1984 through 2007}

By Nancy J. Bauch, Lisa D. Miller, and Sharon Yacob

Prepared in cooperation with the Summit Water Quality Committee

Scientific Investigations Report 2013-5129 


\title{
U.S. Department of the Interior SALLY JEWELL, Secretary
}

\section{U.S. Geological Survey Suzette M. Kimball, Acting Director}

\author{
U.S. Geological Survey, Reston, Virginia: 2014
}

For more information on the USGS - the Federal source for science about the Earth, its natural and living resources, natural hazards, and the environment, visit http://www.usgs.gov or call 1-888-ASK-USGS.

For an overview of USGS information products, including maps, imagery, and publications, visit http://www.usgs.gov/pubprod

To order this and other USGS information products, visit http://store.usgs.gov

Any use of trade, firm, or product names is for descriptive purposes only and does not imply endorsement by the U.S. Government.

Although this information product, for the most part, is in the public domain, it also may contain copyrighted materials as noted in the text. Permission to reproduce copyrighted items must be secured from the copyright owner.

Suggested citation:

Bauch, N.J., Miller, L.D., and Yacob, Sharon, 2014, Analysis of water quality in the Blue River watershed, Colorado, 1984 through 2007: U.S. Geological Survey Scientific Investigations Report 2013-5129, 91 p., http://dx.doi.org/10.3133/ sir20135129.

ISSN 2328-0328 (online) 


\section{Contents}

Abstract

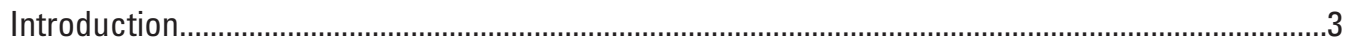

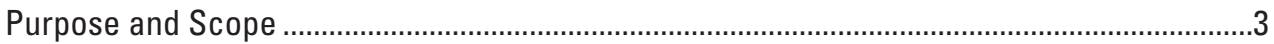

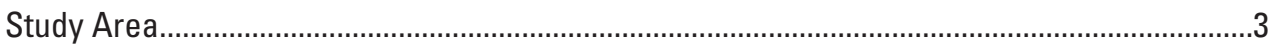

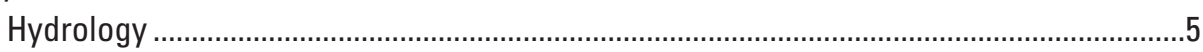

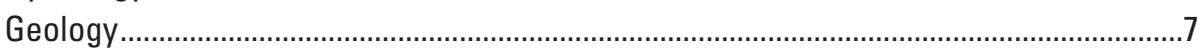

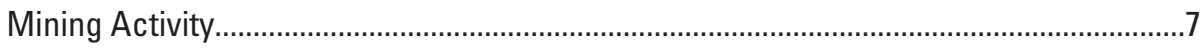

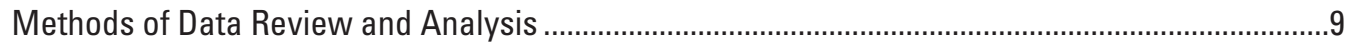

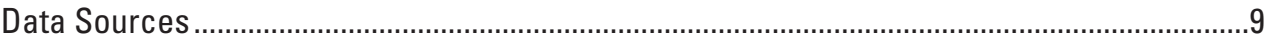

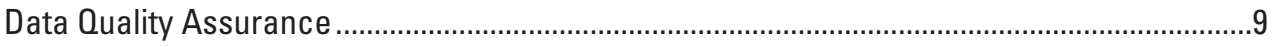

Data Compilation and Comparison ......................................................................................

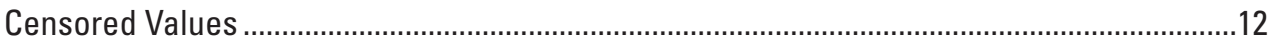

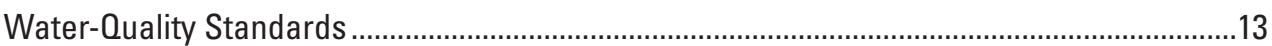

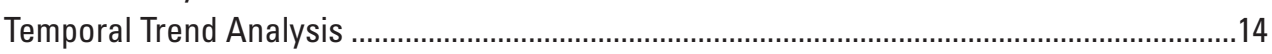

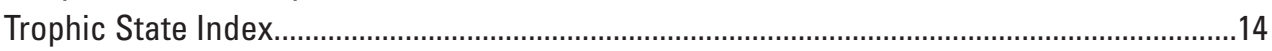

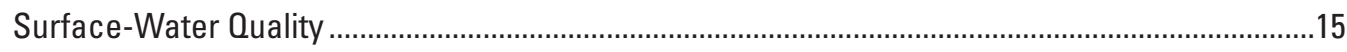

Overview of Physical Properties and Water-Quality Constituents..........................................15

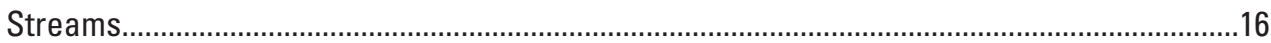

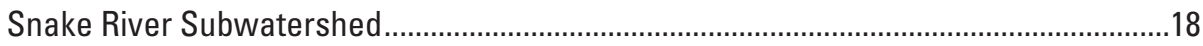

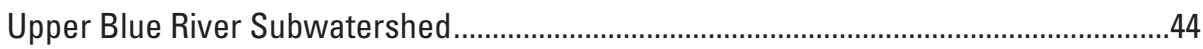

Tenmile Creek Subwatershed ....................................................................................

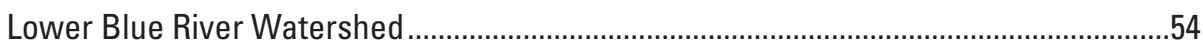

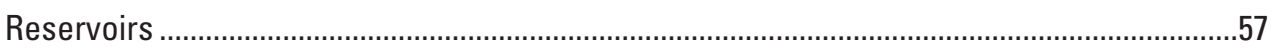

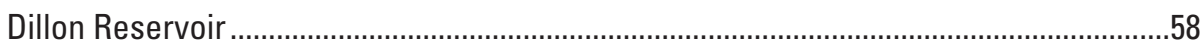

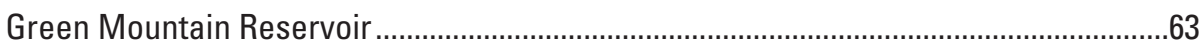

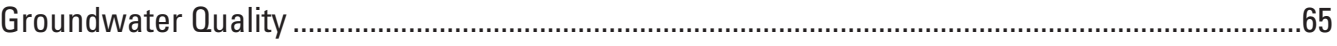

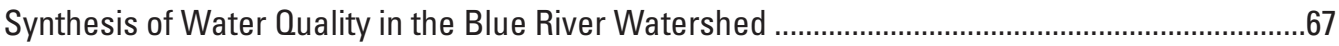

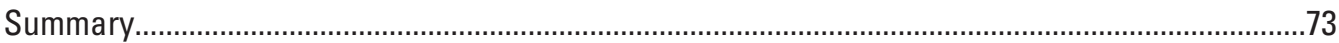

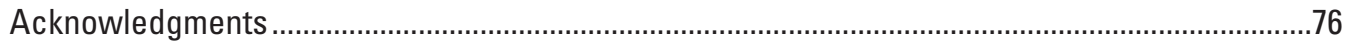

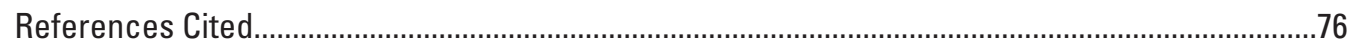

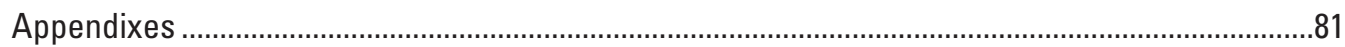

1. Stream sites in the Blue River watershed with six or more water-quality samples or exceedances of Colorado Department of Public Health and Environment trace element water-quality standards for protection of aquatic life or domestic water supply and selected reservoir sites.

2. Streamflow-gaging stations in the Blue River watershed not included in the Blue River watershed water-quality database, water year 1904 through 2010

3. Number of surface-water-quality samples for physical properties, major ions, nutrients, trace elements, suspended sediment, and coliform bacteria for the Snake River, upper Blue River, and Tenmile Creek subwatersheds and the lower Blue River watershed by source agency, Blue River watershed, Colorado, October 1995 through December 2006.

4. U.S. Environmental Protection Agency STORET edit-checking procedure of low and high values for selected water-quality parameters in the Blue River watershed water-quality database. 


\section{Figures}

1. Map showing location of the Blue River watershed, Colorado .....................................

2. Map showing land cover in the Blue River watershed, Colorado, 2001 ...........................6

3. Map showing location and mean streamflow for U.S. Geological Survey (USGS) streamflow-gaging stations and graph showing mean monthly streamflows for water year (WY) 2007 for selected USGS streamflow-gaging stations, Blue River watershed, Colorado...

4. Map showing geology of the Blue River watershed, Colorado 10

5. Map showing location of suface-water sites with six or more water-quality samples or exceedances of Colorado Department of Public Health and Environment trace-element water-quality standards for the protection of aquatic life or domestic water supply, Blue River watershed, Colorado

6. Map showing spatial distribution of median values of specific conductance for selected sites in the Blue River watershed with six or more samples, 1995 through 2006

7. Map showing spatial distribution of median values of $\mathrm{pH}$ for selected sites in the Blue River watershed with six or more samples, 1995 through 2006.

8. Graphs showing concentrations of major ions in water from stream sites in the $(A)$ Snake River and $(B)$ upper Blue River subwatersheds with water types affected and not affected by historical mining or mineralized bedrock.

9. Map showing spatial distribution of median concentrations of nitrate for selected sites in the Blue River watershed with six or more samples, 1995 through 2006.

10. Map showing spatial distribution of median concentrations of total phosphorus for selected sites in the Blue River watershed with six or more samples, 1995 through 2006

11. Map showing spatial distribution of median concentrations of dissolved cadmium for selected sites in the Blue River watershed with six or more samples, 1995 through 2006

12. Map showing spatial distribution of median concentrations of dissolved copper for selected sites in the Blue River watershed with six or more samples, 1995 through 2006

13. Map showing spatial distribution of median concentrations of dissolved manganese for selected sites in the Blue River watershed with six or more samples, 1995 through 2006

14. Map showing spatial distribution of median concentrations of dissolved zinc for selected sites in the Blue River watershed with six or more samples, 1995 through 2006

15. Map showing spatial distribution of sites with trace-element concentrations that exceed Colorado Department of Public Health and Environment (CDPHE) trace-element water-quality standards for protection of aquatic life and number of constituents that are exceeded at a site, 1995 through 2006.

16. Graph showing time series of sample collection for selected sites in Dillon and Green Mountain Reservoirs, Blue River watershed, 1966-2007

17. Graph showing mean annual growing season (July-October) total phosphorus concentration in the top 15 meters (49.21 feet) of Dillon Reservoir, Dillon Reservoir near dam (west) (site 135), 1984-2007 
18. Graphs showing $(A)$ Mean annual total phosphorus and $(B)$ chlorophyll- $a$ concentrations and $(C)$ mean Secchi disk transparency with trophic-state boundaries, Dillon Reservoir near dam (site 135), 1984-2007

19. Graphs showing $(A)$ Mean annual total phosphorus and $(B)$ chlorophyll- $a$

concentrations and $(C)$ mean Secchi disk transparency with trophic-state boundaries, Green Mountain Reservoir between Henney and dam (site 137), 1984-2007.

\section{Tables}

1. Land cover in the Blue River watershed, Colorado, 2001

2. Number of stream sites and samples with water-quality data by subwatershed or watershed and constitutent group, Blue River watershed, Colorado, October 1995 through December 2006.

3. Summary of procedures used to aggregate nutrient data into constituent groups, Blue River watershed, Colorado

4. Total number of water-quality samples collected per season by subwatershed or watershed, Blue River watershed, Colorado, October 1995 through December 2006.

5. Summary of the number of samples and sites, minimum, median, and maximum values, and Colorado Department of Public Heath and Environment in-stream water-quality standards for stream-water samples in the Snake River subwatershed, Blue River watershed, Colorado, 1995 through 2006

6. Exceedances of Colorado Department of Public Health and Environment in-stream water-quality standards for trace elements in the Snake River, upper Blue River, and Tenmile Creek subwatersheds and the lower Blue River watershed, Blue River watershed, Colorado, October 1995 through July 2006

7. Comparison of percentage of stream-water samples with trace-element concentrations exceeding Colorado Department of Public Health and Environment in-stream water-quality standards for protection of aquatic life for the Snake River, upper Blue River, and Tenmile Creek subwatersheds and the lower Blue River watershed, Blue River watershed, Colorado, October 1995 through July 2006

8. Summary of the number of samples and sites, minimum, median, and maximum values, and Colorado Department of Public Health and Environment in-stream water-quality standards for stream-water samples in the upper Blue River subwatershed, Blue River watershed, Colorado, 1995 through 2006.

9. Summary of the number of samples and sites, minimum, median, and maximum values, and Colorado Department of Public Health and Environment in-stream water-quality standards for stream-water samples in the Tenmile Creek subwatershed, Blue River watershed, Colorado, 1995 through 2006

10. Summary of the number of samples and sites, minimum, median, and maximum values, and Colorado Department of Public Health and Environment in-stream water-quality standards for stream-water samples in the lower Blue River watershed, Blue River watershed, Colorado, 1995 through 2006

11. Time period of sample collection, number of sample days, and number of individual samples for selected sites in Dillon and Green Mountain Reservoirs, Blue River watershed, Colorado 
12. Summary of the number of samples, minimum, median, and maximum values, and Colorado Department of Public Health and Environment water-quality standards for water-quality samples at Dillon Reservoir near dam (west) (site 135) and Green Mountain Reservoir between Heeney and dam (site 137), Blue River watershed, Colorado.

13. Results of seasonal Kendall trend analysis for selected water-quality properties and constituents for Dillon Reservoir near dam (west) (site 135), Blue River watershed, Colorado, 1984 through 2007.

14. Number of wells and groundwater samples with water-quality data by constitutent group, Blue River watershed, Colorado, 1996 through 2004

15. Summary of the number of groundwater samples and wells, minimum, median, and maximum values, and Colorado Department of Public Health and Environment water-quality standards for groundwater, Blue River watershed, Colorado, 1996 through 2004

\section{Conversion Factors, Abbreviations, Initialisms, Datum, and Acronyms}

\begin{tabular}{|c|c|c|}
\hline Multiply & By & To obtain \\
\hline \multicolumn{3}{|c|}{ Length } \\
\hline foot $(\mathrm{ft})$ & 0.3048 & meter \\
\hline inch (in.) & 2.54 & centimeter \\
\hline meter $(\mathrm{m})$ & 3.28 & foot \\
\hline micron $(\mu)$ & $3.9370 \times 10^{-5}$ & kilometer \\
\hline mile $(\mathrm{mi})$ & 1.609 & kilometer \\
\hline \multicolumn{3}{|c|}{ Area } \\
\hline acre & 4,047 & square meter \\
\hline square mile $\left(\mathrm{mi}^{2}\right)$ & 2.590 & square kilometer \\
\hline \multicolumn{3}{|c|}{ Volume } \\
\hline acre-foot (acre-ft) & 1,233 & cubic meter \\
\hline milliliter $(\mathrm{mL})$ & 0.0338 & ounce, fluid \\
\hline \multicolumn{3}{|c|}{ Flow rate } \\
\hline cubic foot per second $\left(\mathrm{ft}^{3} / \mathrm{s}\right)$ & 0.02832 & cubic meter per second \\
\hline \multicolumn{3}{|c|}{ Mass } \\
\hline kilogram per year $(\mathrm{kg} / \mathrm{y})$ & 2.205 & pound, avoirdupois, per year \\
\hline
\end{tabular}

Temperature in degrees Celsius $\left({ }^{\circ} \mathrm{C}\right)$ may be converted to degrees Fahrenheit $\left({ }^{\circ} \mathrm{F}\right)$ as follows:

$$
{ }^{\circ} \mathrm{F}=\left(1.8 \mathrm{x}^{\circ} \mathrm{C}\right)+32
$$

Temperature in degrees Fahrenheit $\left({ }^{\circ} \mathrm{F}\right)$ may be converted to degrees Celsius $\left({ }^{\circ} \mathrm{S}\right)$ as follows:

$$
{ }^{\circ} \mathrm{C}=\left({ }^{\circ} \mathrm{F}-32\right) / 1.8
$$

Horizontal coordinate information is referenced to the North American Datum of 1983 (NAD 83).

Specific conductance is given in microsiemens per centimeter at 25 degrees Celsius $(\mu \mathrm{S} / \mathrm{cm}$ at $\left.25^{\circ} \mathrm{C}\right)$.

Concentrations of chemical constituents in water are given either in milligrams per liter (mg/L) or micrograms per liter $(\mu \mathrm{g} / \mathrm{L})$. 


\title{
Abbreviations, Initialisms, and Acronyms
}

\author{
AMLE Adjusted maximum likelihood estimation \\ $\mathrm{CaCO}_{3} \quad$ calcium carbonate \\ CDPHE Colorado Department of Public Health and Environment \\ $\mathrm{col} / 100 \mathrm{~mL}$ colonies per 100 milliliters \\ DM Daily Maximum \\ E. coli Escherichia coli \\ ESTREND EStimate TREND \\ $\mathrm{HCO}_{3}^{-} \quad$ bicarbonate \\ HR Inc Hydrosphere Resource Consultants, Inc. \\ INSTAAR University of Colorado Institute of Arctic and Alpine Research \\ MCL maximum contaminant level \\ MWAT Maximum Weekly Average Temperature \\ $\mathrm{NH}_{3} \quad$ un-ionized ammonia \\ $\mathrm{NH}_{4^{+}} \quad$ ammonium \\ ROS Regression of ordered statistics \\ SCEHD Summit County Environmental Health Department \\ SKT Seasonal Kendall test \\ STORET STOrage and RETrieval \\ SWOC Summit Water Quality Committee \\ TMDL Total Daily Maximum Load \\ TVS table value standard \\ USEPA U.S. Environmental Protection Agency \\ USGS U.S. Geological Survey \\ WY water year (a 12-month period beginning 0ctober 1 and ending September 30 \\ of the following year. A water year is designated as the year in which it ends.)
}





\title{
Analysis of Water Quality in the Blue River Watershed, Colorado, 1984 through 2007
}

\author{
By Nancy J. Bauch, Lisa D. Miller and Sharon Yacob
}

\section{Abstract}

Water quality of streams, reservoirs, and groundwater in the Blue River watershed in the central Rocky Mountains of Colorado has been affected by local geologic conditions, historical hard-rock metal mining, and recent urban development. With these considerations, the U.S. Geological Survey, in cooperation with the Summit Water Quality Committee, conducted a study to compile historical water-quality data and assess water-quality conditions in the watershed. To assess water-quality conditions, stream data were primarily analyzed from October 1995 through December 2006, groundwater data from May 1996 through September 2004, and reservoir data from May 1984 through November 2007. Stream data for the Snake River, upper Blue River, and Tenmile Creek subwatersheds upstream from Dillon Reservoir and the lower Blue River watershed downstream from Dillon Reservoir were analyzed separately.

In the Snake River subwatershed, water-quality data for 148 stream sites were analyzed. Most water temperature values and dissolved-oxygen concentrations met Colorado Department of Public Health and Environment (CDPHE) water-quality standards for protection of cold-water aquatic life. About 31 percent of $\mathrm{pH}$ values measured were less than 6.5 because of acidic drainage from mineralized bedrock and historical hard-rock metal mining. Most of these low $\mathrm{pH}$ values were measured at sites in the headwaters of the Snake River and Peru Creek. Concentrations of chloride, sulfate, dissolved solids, total ammonia, and nitrite met water-quality standards. All but one site in the Snake River subwatershed, Soda Creek at inlet to weir, had median nitrate concentrations equal to or less than 0.50 milligrams per liter $(\mathrm{mg} / \mathrm{L})$. About 14 percent of the nitrate concentrations in samples collected from the Soda Creek site were greater than the $10 \mathrm{mg} / \mathrm{L}$ CDPHE domestic water-supply standard. Median total phosphorus concentrations at all 15 sites with 6 or more samples were less than or equal to $0.03 \mathrm{mg} / \mathrm{L}$. Concentrations of total phosphorus in some individual samples equaled or exceeded the U.S. Environmental Protection Agency (USEPA) recommended concentration limit $(0.05 \mathrm{mg} / \mathrm{L})$ for streams that flow directly into reservoirs.
Concentrations of dissolved and total recoverable arsenic and dissolved chromium and uranium were low in the Snake River subwatershed, as were most concentrations of total mercury and dissolved silver. Concentrations of dissolved aluminum, cadmium, copper, iron, lead, manganese, and zinc and total recoverable iron were high (concentrations often exceeded water-quality standards) in areas affected by naturally occurring acidic and metal-enriched drainage and in mined areas, particularly in the upper Snake River and Peru Creek. Dissolved cadmium, copper, manganese, and zinc and total recoverable iron remained elevated in the Snake River downstream to Dillon Reservoir. Concentrations of dissolved cadmium, copper, lead, manganese, selenium, silver, and zinc, dissolved and total recoverable iron, and total mercury at 66 sites did not meet CDPHE standards for aquatic-life protection, most often for zinc, cadmium, and copper. Low $\mathrm{pH}$, high trace-element concentrations, and precipitation of metal oxides have negatively affected the diversity and abundance of aquatic life in some reaches of the Snake River.

Water-quality data for 51 stream sites in the upper Blue River subwatershed were analyzed. Almost all water temperature values and dissolved-oxygen concentrations met CDPHE standards for aquatic-life protection. Only 6 percent of the $\mathrm{pH}$ values did not meet the CDPHE standard. Concentrations of chloride, sulfate, dissolved solids, total ammonia, nitrite, and nitrate met water-quality standards. The USEPArecommended concentration limit for total phosphorus to control eutrophication in downstream water bodies was exceeded in less than 4 percent of the samples collected at three Blue River sites just upstream from Dillon Reservoir.

Concentrations of dissolved arsenic, selenium, and uranium and total mercury generally were low throughout the upper Blue River subwatershed. Dissolved aluminum, copper, and lead concentrations were higher in mined areas but were still relatively low overall. Concentrations of dissolved cadmium, iron, manganese, and zinc and total recoverable iron were high in mined areas of French Gulch and downstream sites along French Gulch, Blue River, and Illinois Gulch. Dissolved iron, manganese, and zinc and total recoverable iron remained elevated at sites on the Blue River downstream to Dillon Reservoir. Concentrations of dissolved cadmium, 
chromium, copper, lead, manganese, nickel, silver, and zinc and total recoverable iron at 21 sites in the subwatershed exceeded CDPHE standards for aquatic-life protection. Exceedances were most frequent at mining sites and sites downstream from historical mining areas. Because of toxicity effects, elevated concentrations of trace elements have limited the survivability of aquatic biota in some stream reaches in the upper Blue River subwatershed.

In the Tenmile Creek subwatershed, water-quality data for 19 sites were analyzed. Most water temperature values and dissolved-oxygen concentrations met CDPHE standards. Median specific conductance values at sites along West Tenmile Creek were generally less than 200 microsiemens per centimeter $(\mu \mathrm{S} / \mathrm{cm})$; the highest median concentration for Tenmile Creek sites was $1,055 \mu \mathrm{S} / \mathrm{cm}$. All but two values of $\mathrm{pH}$ were within the CDPHE standard for protection of aquatic life. All chloride concentrations met the CDPHE domestic water-supply standard. The CDPHE domestic water-supply standard for sulfate of $250 \mathrm{mg} / \mathrm{L}$ was exceeded in 8 percent of samples collected from applicable stream reaches. The USEPA-recommended dissolved-solids concentration of $500 \mathrm{mg} / \mathrm{L}$ was exceeded in 28 percent of samples. All total ammonia, nitrite, and nitrate concentrations met CDPHE aquatic life or domestic water-supply standards. For streams that do not directly flow into reservoirs, the recommended total phosphorus limit of $0.1 \mathrm{mg} / \mathrm{L}$ was exceeded in five samples, four from West Tenmile Creek and one from Ten Mile Creek above Wheeler Junction.

Concentrations of dissolved and total recoverable arsenic, dissolved chromium, copper, nickel, selenium, and silver, and total mercury typically were low throughout the Tenmile Creek subwatershed. Dissolved aluminum, cadmium, manganese, and zinc concentrations and dissolved and total recoverable iron were elevated at a few sites. Concentrations of dissolved cadmium, dissolved lead, and total recoverable iron exceeded CDPHE standards in 4.9 percent of samples collected. The cadmium standard was exceeded at the most sites in the Tenmile Creek subwatershed, followed by lead, and total recoverable iron. Engineering projects and reclamation in mined areas of the Tenmile Creek headwaters have led to substantial improvements in water quality in Tenmile Creek.

In the lower Blue River watershed, water-quality data for 33 sites were analyzed. Almost all water-temperature measurements and dissolved-oxygen concentrations met the CDPHE standard for aquatic-life protection. Most specific conductance values were less than or equal to $300 \mu \mathrm{S} / \mathrm{cm}$. Almost all $\mathrm{pH}$ values were within the CDPHE standard. All chloride, sulfate, dissolved-solids, total ammonia, nitrite, and nitrate concentrations met CDPHE domestic water-supply and aquatic-life standards and a USEPA-recommended limit. The USEPArecommended total phosphorus concentration of $0.05 \mathrm{mg} / \mathrm{L}$ for streams that directly flow into reservoirs was exceeded in one Blue River sample. The recommended total phosphorus concentration of $0.1 \mathrm{mg} / \mathrm{L}$ for streams that do not directly flow into reservoirs was exceeded in 27 samples collected between 1997 and 2003 from 6 sites.
Most trace-element concentrations in the lower Blue River watershed were lower than those upstream from Dillon Reservoir. Concentrations of dissolved aluminum, arsenic, cadmium, chromium, copper, lead, nickel, selenium, and silver and total mercury generally were less than laboratory reporting levels, although elevated concentrations were measured in some samples. Concentrations of dissolved cadmium, copper, lead, manganese, and zinc and total recoverable iron exceeded water-quality standards in some samples. Exceedances occurred in 3.8 percent of samples collected, similar to proportion of exceedances in the Tenmile Creek subwatershed but much less than those for the Snake River and upper Blue River subwatersheds.

Water-quality data collected from 1984 to 2007 at one site in Dillon Reservoir were analyzed. Water-temperature measurements met the CDPHE standard for aquatic-life protection. The dissolved-oxygen standard was not met on some days during early fall between 2002 and 2007; chronic low dissolved oxygen conditions were not indicated. Transparency generally was lowest during May through July likely because of snowmelt runoff. Nitrate concentrations were well below the CDPHE domestic water-supply standard. The mean annual total phosphorus concentration in the top 15 meters (49.21 feet) during the growing season was less than the CDPHE water-quality standard for all years except 2002 and 2004. Elevated concentrations during 2002 and 2004 are likely the result of drought rather than increases from natural and anthropogenic sources. A statistically significant upward trend in nitrate concentrations in the top 15 meters of the water column during the growing season was indicated for 1984-2007. The rate of change was small, less than 0.001 milligram per liter per year.

Water-quality data collected from most years between 1984 and 1999 and during 2005 and 2007 at one site in Green Mountain Reservoir were analyzed. CDPHE standards for water temperature and dissolved oxygen were met except for a few days during 2005 and 2007. Transparency was at a minimum during 2007 during snowmelt runoff. The maximum transparency was less than that for Dillon Reservoir. Nitrate concentrations were well below the CDPHE waterquality standard. The median growing season total phosphorus concentration for the top 15 meters during 2007 was greater than that for Dillon Reservoir. Chlorophyll- $a$ typically was suppressed in Green Mountain Reservoir because the short residence time of water limited algal growth.

Water-quality data for groundwater were analyzed for 1,955 samples collected from 1,234 wells during 1996 through 2004. Almost all wells were sampled as part of a study on total nitrate in domestic drinking-water wells. Most total nitrate concentrations in samples from domestic wells were less than $0.5 \mathrm{mg} / \mathrm{L}$. In the area downstream from Silverthorne to Green Mountain Reservoir, total nitrate concentrations in well samples were similar to those for total and dissolved concentrations in streams. In other areas, concentrations were higher in groundwater. Elevated concentrations of major ions and trace elements were detected in many samples collected from the highly mineralized and mined area of French Gulch. 


\section{Introduction}

The Blue River watershed is west of the Continental Divide in central Colorado (fig. 1). In the headwaters area (hereinafter defined as the upper Blue River watershed), the Snake River, Blue River, and Tenmile Creek flow into Dillon Reservoir. In the lower Blue River watershed downstream from Dillon Reservoir, the Blue River flows northward into and out from Green Mountain Reservoir before reaching its confluence with the Colorado River near Kremmling, Colorado. The upper Blue River watershed is located in the Colorado Mineral Belt (Gilliland, 2006), a zone of economically significant metal deposits. Hard-rock mining was the major industry in the upper Blue River watershed from 1859 through the first half of the 1900s (Gilliland, 2006). Since the development of Arapahoe Basin Ski Area in 1945 and other ski areas in the early 1960s, the primary economic bases in the upper Blue River watershed have been recreation-based tourism and second-home development (Northwest Colorado Council of Governments, 2012).

Geologic conditions, including mineralized bedrock and sedimentary rocks, historical hard-rock mining, and urban development have affected water quality and aquatic biota in the Blue River watershed. Low values of $\mathrm{pH}$ and high concentrations of trace elements such as aluminum, cadmium, copper, iron, manganese, and zinc in water can occur naturally from the weathering of mineralized rocks and anthropogenically from hard-rock acidic mine drainage (Todd, 2005; Todd and others, 2005). The amount of dissolved constituents in water can be high in areas with sedimentary rocks (Bauch and Spahr, 1998). Runoff from developed lands and septic and wastewater systems can affect nutrient concentrations in water bodies, along with sediment loading (Dubrovsky and others, 2010; U.S. Geological Survey, 2014). With these considerations, the U.S. Geological Survey (USGS), in cooperation with the Summit Water Quality Committee, conducted a study to compile water-quality data and assess water-quality conditions in the Blue River watershed. The Summit Water Quality Committee includes the Breckenridge Sanitation District, Climax Molybdenum Co., Copper Mountain Consolidated Metropolitan District, Denver Water Board, Frisco Sanitation District, Silverthorne/Dillon Joint Sewer Authority, Snake River Wastewater Treatment Facility, Summit County, and the towns and municipalities of Breckenridge, Dillon, Frisco, Montezuma, and Silverthorne. Specific objectives of the study were to

- Characterize available water-quality data for the Blue River watershed,

- Analyze historical data and describe the spatial and seasonal distribution and temporal trends of waterquality data,

- Identify, describe, and explain, where possible, the natural and human factors that could be affecting observed water-quality conditions, and

- Develop a water-quality and aquatic biota database from available data in the watershed.

\section{Purpose and Scope}

This report presents the results of the analysis of waterquality data collected in the Blue River watershed by Federal, State, and local agencies, academic institutions, environmental consulting firms, and a ski resort. Data from the various sources that were available in an electronic (computerized database) format were compiled into a Web-accessible USGS water-quality database for the Blue River watershed (available at http://rmgsc.cr.usgs.gov/cwqdr/Blue/index.shtml). Waterquality data collected from May 1984 through November 2007 for physical properties, major ions, and dissolved and suspended solids, nutrients, trace elements, coliform bacteria, and algae (chlorophyll- $a$ ) in streams, reservoirs, and(or) groundwater were retrieved from the database for analysis. Analysis of stream and groundwater data focused primarily on subsets of data: stream water (October 1995 through December 2006) and groundwater (May 1996 through September 2004).

Reservoir data were analyzed for May 1984 through November 2007. Stream, reservoir, and groundwater data were summarized and compared to State of Colorado water-quality standards. Maps of the distribution of median values and concentrations of selected water-quality physical properties and chemical constituents for stream water are presented. Where sufficient surface-water data were available, trend analysis was conducted to identify changes in selected water-quality conditions over time, and results are presented.

\section{Study Area}

The Blue River watershed is west of the Continental Divide in the central Rocky Mountains of Colorado and drains 680 square miles $\left(\mathrm{mi}^{2}\right)$. The watershed includes all of Summit County $\left(619 \mathrm{mi}^{2}\right)$, a small section in Grand County $\left(80 \mathrm{mi}^{2}\right)$, and a smaller section in Lake County (Northwest Colorado Council of Governments, 2012) (fig. 1). Headwaters for the Blue River watershed originate in the alpine environments of the Williams Fork Mountains (eastern boundary of the watershed), Continental Divide (southern and southeastern boundary), and the Gore Range (western boundary). Major tributaries draining the watershed upstream from Dillon Reservoir include the westerly flowing Snake River, the northerly flowing Blue River, and the northeasterly flowing Tenmile Creek. Drainage areas for these tributaries are $115 \mathrm{mi}^{2}$ for the Snake River, $121 \mathrm{mi}^{2}$ for the Blue River, and $93 \mathrm{mi}^{2}$ for Tenmile Creek (Greve and others, 2001). Straight Creek, Willow Creek, Bushee Creek, and other small tributaries flow into the Blue River between Dillon Reservoir and Green Mountain Reservoir. Downstream from Green Mountain Reservoir, Beaver and Spruce Creeks, along with other small tributaries, join the Blue River as it flows northward for about 15 mi before discharging into the Colorado River near Kremmling, Colorado.

The drainage area of the Blue River watershed is almost equally split between the areas upstream and downstream from Dillon Reservoir, 335 and $345 \mathrm{mi}^{2}$, respectively. In this 


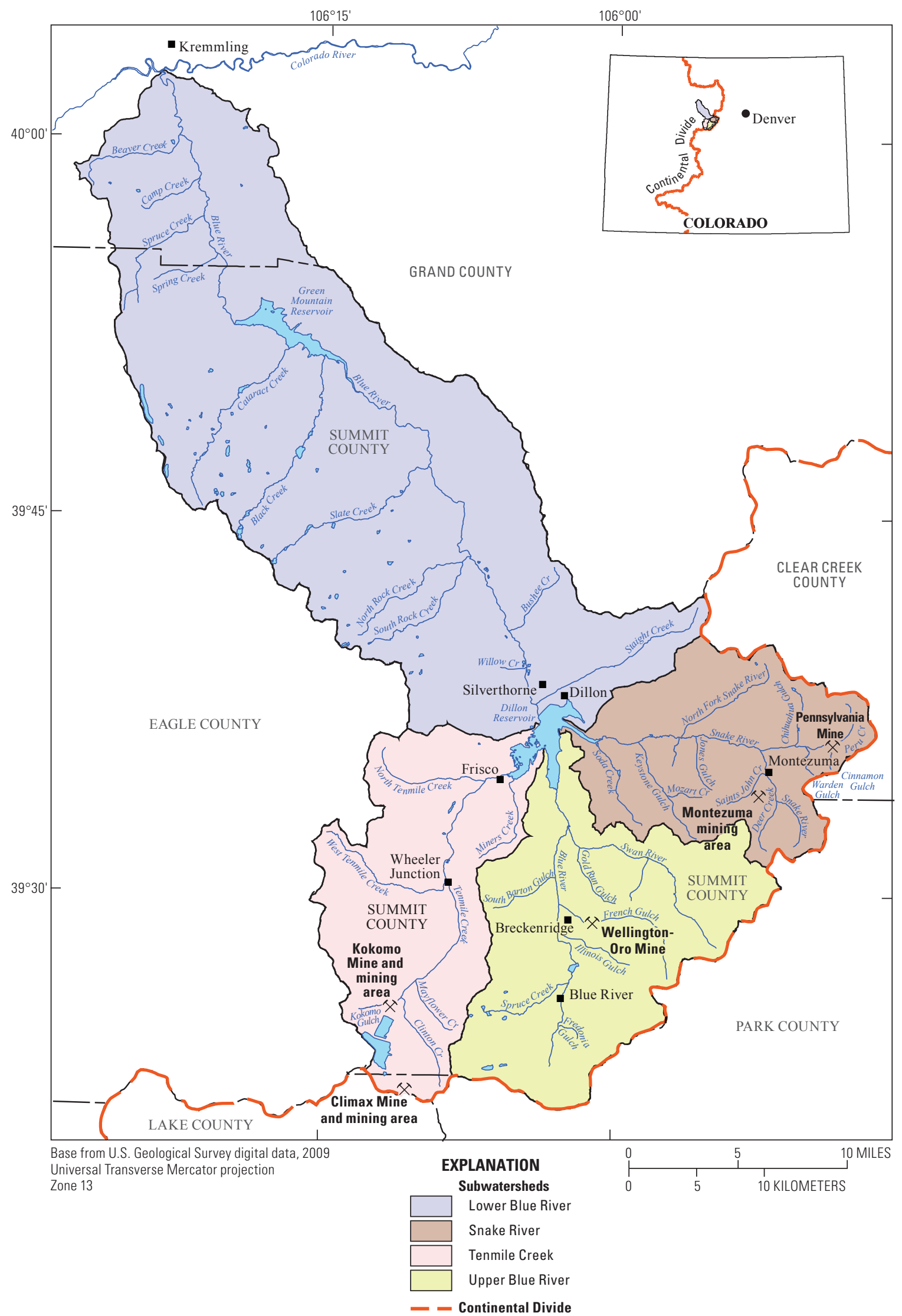

Figure 1. Location of the Blue River watershed, Colorado. 
report, the area of the Blue River watershed upstream from Dillon Reservoir is defined as the upper Blue River watershed. The upper Blue River watershed is further divided into subwatersheds: Snake River subwatershed, upper Blue River subwatershed, and Tenmile Creek subwatershed. Soda Creek, which flows directly into Dillon Reservoir, is considered part of the Snake River subwatershed for purposes of this report. The area downstream from Dillon Reservoir is defined as the lower Blue River watershed. This reach has been designated as a gold medal trout fishery by the Colorado Wildlife Commission (Northwest Colorado Council of Governments, 2012). Land-surface elevations range from 14,270 feet ( $\mathrm{ft}$ ) at the headwaters of the Snake River to $9,017 \mathrm{ft}$ at the Dillon Reservoir spillway to about 7,400 ft at the mouth of the Blue River near Kremmling (Northwest Colorado Council of Governments, 2012; Denver Water, 2008).

Monthly average air temperatures in the Dillon area range from a low of $15.1^{\circ} \mathrm{F}$ in January to a high of $55.8^{\circ} \mathrm{F}$ in July (Western Regional Climate Center, 2014). Precipitation in the Blue River watershed ranges from 10 to 15 inches per year in the lower valleys to 40 to 45 inches per year at the higher peaks (PRISM Group and Oregon Climate Service, 2006). Most precipitation falls as snow during January through April; snowmelt occurs during May through July. Significant rainfall can occur during July and August from thunderstorm activity.

The dominant land cover in the Blue River watershed is forest land, which accounts for about 49 percent of the total land area (fig. 2, table 1). Rangeland and barren land account for about 31 and 9.8 percent of the land area, respectively. The remainder of the land cover in the watershed is perennial ice and snow (3.9 percent), wetland (2.5 percent), urban (2.4 percent), and water (1.4 percent) (LaMotte, 2008). About 80 percent of the land area in the watershed is publicly owned, including National Forest and Bureau of Land Management lands and Wilderness Areas.

The population of Summit County during 2006 was an estimated 27,964 (Colorado Department of Local Affairs, 2008). The largest municipalities were Silverthorne $(3,956)$, Breckenridge $(3,439)$, and Frisco $(2,742)$ (estimated 2006 populations). Smaller municipalities include Dillon, Blue River, and Montezuma, with a combined estimated population during 2006 of 1,619. A large portion (estimated 2006 population of 16,208) of the population of Summit County lives in unincorporated areas of the county. Summit County attracts a large number of visitors for skiing and other recreational activities, including boating in Dillon and Green Mountain Reservoirs, fishing, hiking, and camping. During the 2007-08 ski season, the number of skier days (skier day is one individual visiting a ski area for a day to ski) at Summit County ski areas was 4,125,391 (Summit County Government, 2009). Income from travel-generated activities (day or overnight trips, earnings of employees and businesses, and tax receipts from travel purchases) was predicted to be 819.7 million dollars during 2009 (Dean Runyan Associates, 2010). Nonlocal home ownership was 67 percent in April 2009 (Summit County Government, 2009).

\section{Hydrology}

The USGS operated 41 streamflow-gaging stations in the Blue River watershed for different periods between August 1904 and October 2010 (fig. 3, Appendixes 1 and 2). For water year (WY) 2009 (October 2009 through September 2010), 13 streamflow-gaging stations were active throughout the year or seasonally in the watershed, 2 in the Snake River subwatershed, 6 in the upper Blue River subwatershed, 1 in Tenmile Creek subwatershed, and 4 in the lower Blue River watershed (fig. 3). Real-time streamflow data for active streamflow-gaging stations are available at http://co.water.usgs.gov/infodata/surfacewater.html. Annual streamflow in the Blue River watershed is dominated by spring snowmelt, with increasing flows in April, peak flows in May or June, and decreasing flows in July and August (fig. 3). Thunderstorms in July and August can result in intense but short periods of increased streamflow. Low streamflow generally occurs from October through April and primarily is base flow from groundwater discharge.

The Blue River watershed includes two primary waterstorage facilities, Dillon Reservoir and Green Mountain Reservoir, on the Blue River (fig. 1). Dillon Reservoir, completed in 1963 in the upper Blue River watershed, is owned and operated by the Denver Water Board as a municipal water supply. At full capacity, a total of 254,036 acre-feet (acre-ft) of water is stored in the reservoir, and the surface area is 3,233 acres (Denver Water Board, 2008). The water level fluctuates depending on water availability, storage needs, and demand for drinking and irrigation water and other uses. Dillon Reservoir is just upstream from Silverthorne. The main tributaries to the reservoir are the Snake and Blue Rivers and Tenmile Creek. Water is diverted from the reservoir through the Harold D. Roberts Tunnel (fig. 3) under the Continental Divide into the South Platte River Basin on the eastern slope of the Rocky Mountains for use in the Denver metropolitan area.

From November 2005 through October 2006, 122,018 acre-ft of water was diverted out of the upper Blue River watershed to the Denver metropolitan area, Colorado Springs, other cities along the Front Range, and agricultural users (Colorado Division of Water Resources and Colorado Water Conservation Board, 2008). Most (about 110,000 acre-ft) was diverted from Dillon Reservoir through the Harold D. Roberts Tunnel (fig. 3). Streamflow depletion is a major water issue of concern in the Blue River watershed. Little water is available for new appropriations because of diversions and downstream water requirements. Water diversions reduce the amount of water remaining in a system for dilution of contaminants. The hydraulic residence time for Dillon Reservoir has been as low as 7 months since 1981 but typically is greater than 1 year (Lewis, 2008).

Green Mountain Reservoir, completed in 1943 in the lower Blue River watershed, was built and is operated by the Bureau of Reclamation as part of the Colorado-Big Thompson Project. The Project diverts water from the headwaters of the Colorado River on the western slope of the Continental 


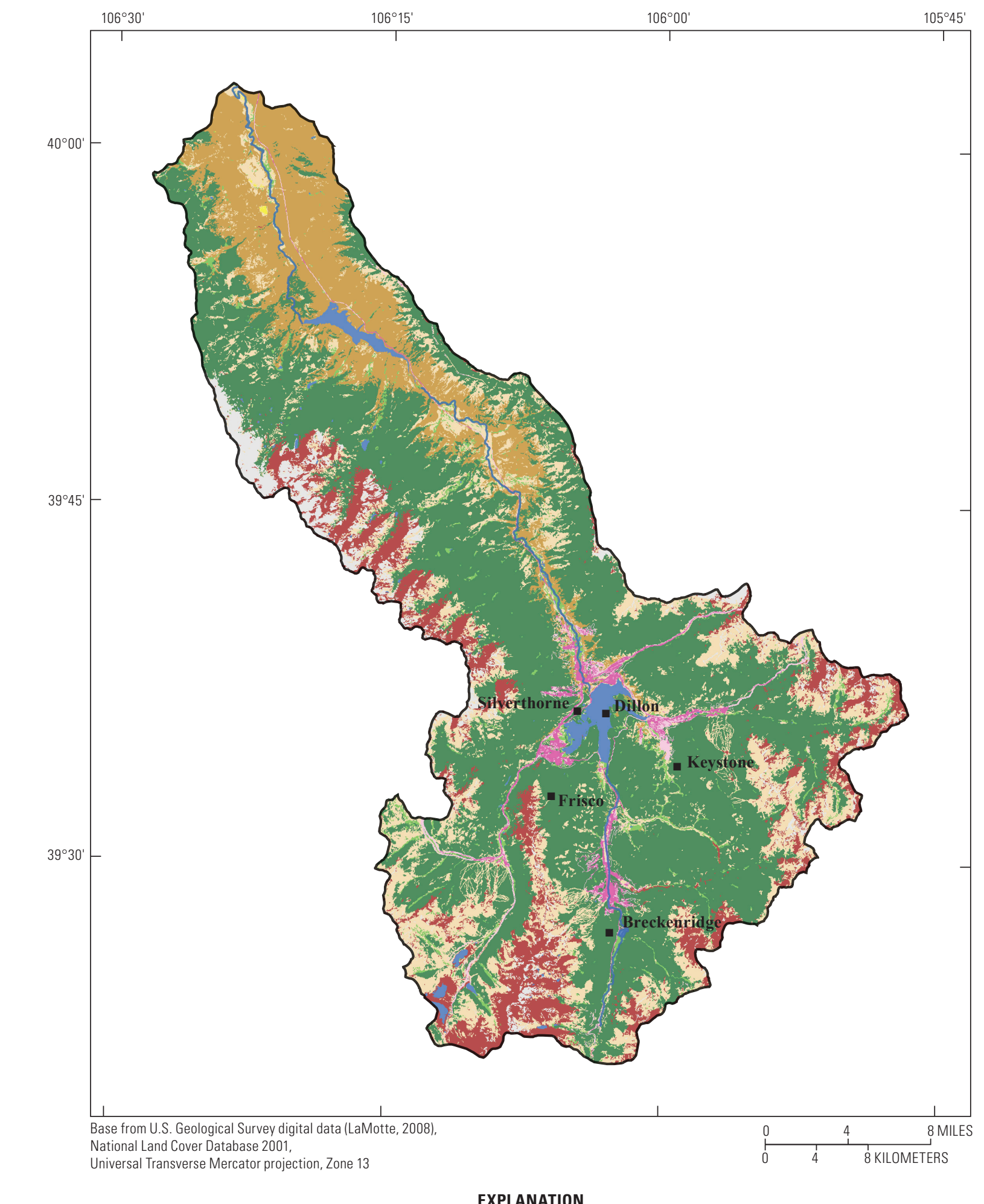

Universal Transverse Mercator projection, Zone 13

\section{EXPLANATION}

Water

Perennial ice/snow Developed, open space Developed
Barren land (rock/sand/clay)

Forest

Shrub/scrub

Grassland/pasture

Figure 2. Land cover in the Blue River watershed, Colorado, 2001. 
Table 1. Land cover in the Blue River watershed, Colorado, 2001. [mi², square mile. Data from LaMotte, 2008]

\begin{tabular}{|c|c|c|}
\hline $\begin{array}{c}\text { Land cover } \\
\text { (fig. 2) }\end{array}$ & $\begin{array}{l}\text { Area } \\
\left(\mathrm{mi}^{2}\right)\end{array}$ & $\begin{array}{l}\text { Percentage } \\
\text { of basin }\end{array}$ \\
\hline Barren $^{1}$ & 66.8 & 9.8 \\
\hline Forest & 334.6 & 49.0 \\
\hline Perennial ice and snow & 26.5 & 3.9 \\
\hline Rangeland $^{2}$ & 211.6 & 31.0 \\
\hline Urban $^{3}$ & 16.7 & 2.4 \\
\hline Water & 10.0 & 1.4 \\
\hline Wetland & 17.2 & 2.5 \\
\hline
\end{tabular}

${ }^{1}$ Areas of bedrock, talus, slides, glacial debris, gravel pits, and other accumulations of earthen material.

${ }^{2}$ Grass, shrub, pasture, and cultivated crop.

${ }^{3}$ Includes developed areas and impervious surface area of highways.

Divide to project lands and communities on the eastern slope (Bureau of Reclamation, 2013). The primary purpose of Green Mountain Reservoir is to compensate residents living west of the Continental Divide for the water diversions to east of the Continental Divide (Northern Colorado Water Conservancy District, 2013). The reservoir has a total capacity of 153,639 acre-feet (Bureau of Reclamation, 2013). Water levels in the reservoir can fluctuate greatly (by tens of feet) depending on downstream water requirements and augmentation needs for water used along the Front Range and in eastern Colorado. Mid-month elevations during 2007 ranged from 7,909 ft in February to 7,950 in July and 7,915 ft in November (Lewis, 2007). The hydraulic residence time for Green Mountain Reservoir has been between 3 and 5 months since 1981 (Lewis, 2008). Increased streamflow from July through September for the Blue River site below Green Mountain Reservoir (site number 119, Appendix 1) is the exception to decreasing streamflow during the same months at other streamflow-gaging station sites in the watershed (fig. 3). Water is released from Green Mountain Reservoir during this time to meet downstream streamflow requirements (Bureau of Reclamation, 2013).

\section{Geology}

Geology in the Blue River watershed ranges from basement rocks of Precambrian age to Quaternary-age alluvium (fig. 4; Green, 1992; Tweto, 1979). Igneous activity in the Tertiary Period created a widespread area of hydrothermally altered rock in the watershed as heated, metal-bearing fluids formed economic mineral deposits (Fey and others, 2002). In the headwaters of Tenmile Creek, the ore deposit in the Climax mining area (fig. 1) is a porphyry molybdenum deposit whereby veins of molybdenite (molybdenum sulfide) are distributed as stockwork in rhyolite intrusions (GlobalInfoMine, 2008). North of the Climax mining area, intrusion of Pennsylvanian- and Permian-age sedimentary rocks by Tertiary-age igneous rocks created silver, lead, and zinc ore deposits in the Kokomo mining area that are unrelated to the Climax mining area. These massive sulfide limestone-replacement orebodies are characterized by high pyrite content, black sphalerite, and galena (Bergendahl and Koschmann, 1971; Mach and Thompson, 1998; Beaty and others, 1990; Gilliland, 2006). The dominant ore host in the Kokomo mining area is thin limestone beds of the Pennsylvanian Minturn Formation (Mach and Thompson, 1998). Precambrian-age granite and gneiss form peaks in the Tenmile Range between Tenmile Creek and the upper Blue River. East of the Blue River, extensive Tertiary-age igneous intrusions into Cretaceous-age shale formed the ore deposits mined in the French Gulch area. Ore deposits consist of stockworks and veins of gold, lead, silver, and zinc, metamorphic replacement deposits, and deposits of gold and silver in Dakota quartzite (Lovering, 1934). The ore mineralogy includes pyrite, sphalerite, chalcopyrite, and galena (Lovering, 1934). The Snake River subwatershed also is composed of Precambrian-age gneiss with extensive Tertiary intrusions producing the mineralization in the Montezuma mining area and other areas of the upper Snake River subwatershed. According to Gilliland (2006), geologists believed that the rich silver belt that cropped out in the Snake River subwatershed also outcropped in the upper Tenmile Creek subwatershed.

North from Dillon Reservoir, geology of the lower Blue River watershed along the Blue River consists of Quaternaryage glacial drift, landslides, gravels, and alluvium overlying Cretaceous-age sedimentary rocks of the Pierre Shale, the Colorado Group (Niobrara Formation and Benton Shale), and the Dakota Sandstone. Precambrian-age granite and gneiss are present along Straight Creek with the Quaternary deposits and small outcroppings of the Cretaceous sedimentary rocks. The Precambrian granite and gneiss form the Gore Range and the Williams Fork Mountains along the western and eastern boundaries of the watershed. North from Green Mountain Reservoir, there is a change from the igneous and metamorphic Precambrian rocks to predominantly Cretaceous-age sedimentary rocks.

\section{Mining Activity}

Hard-rock mining began in Summit County with the discovery of gold in 1859 in the Blue River north of Breckenridge in the Colorado Mineral Belt (Gilliland, 2006). Extensive placer dredging and load mining were in operation from the late 1850 s to the 1960s; lead, silver, zinc, and gold were recovered (Apodaca and others, 2000; Kellogg and others, 2002). Much of the mining occurred along French Gulch. The Wellington-Oro mine and milling site along French Gulch was the largest in the upper Blue River subwatershed. Gold was discovered in the upper Tenmile River subwatershed just below Fremont Pass in 1861. No significant mining activity occurred until 1878 when rich silver deposits were discovered on the west side of the upper Tenmile Creek valley (Koschmann and Bergendahl, 1968). Silver lead ores were mined in the early years; zinc from sulfide ore was mined after 1900 (Mach and Thompson, 1998). Molybdenum was discovered near Fremont Pass in 1879. The deposit would 


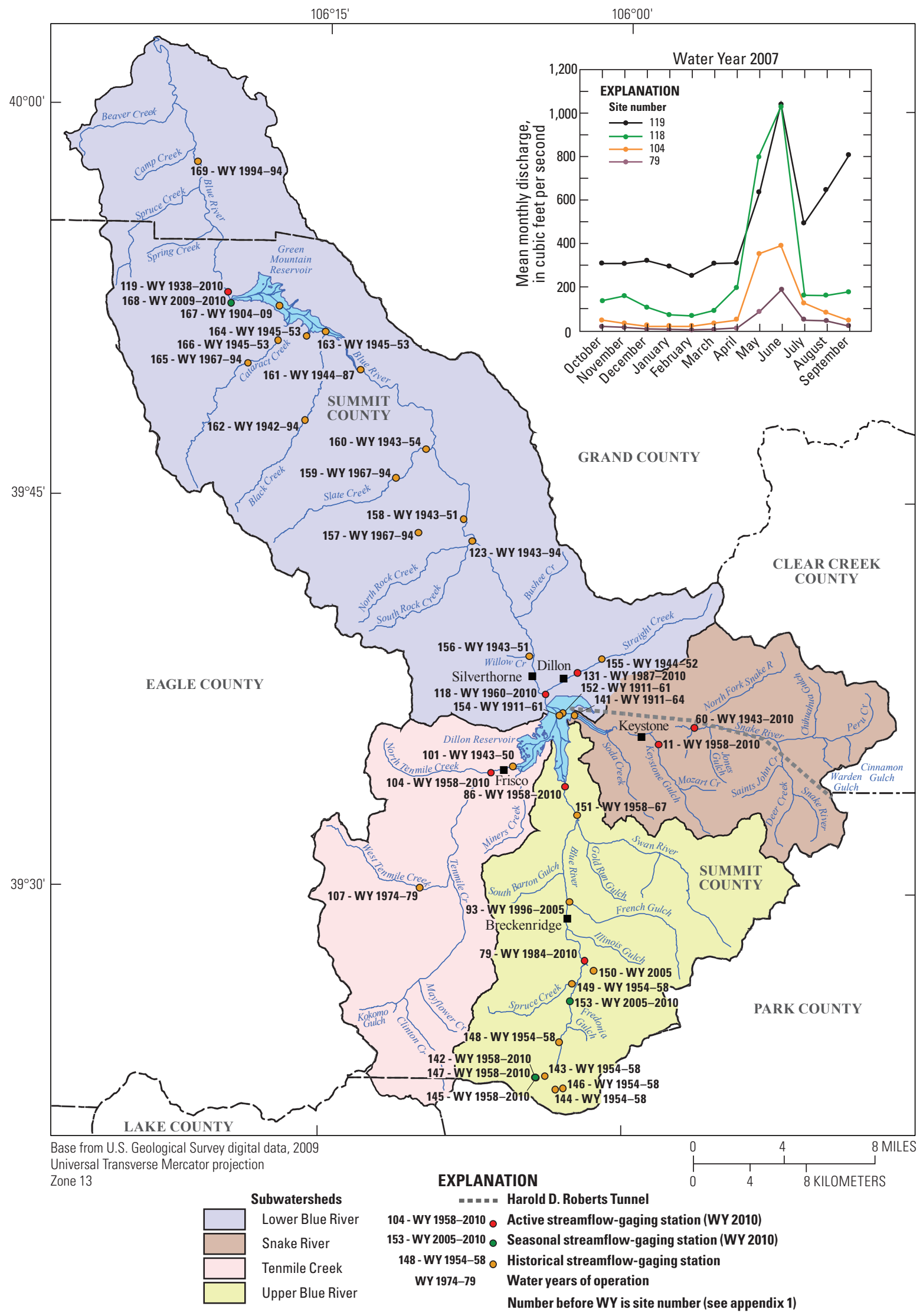

Figure 3. Location and mean streamflow for U.S. Geological Survey (USGS) streamflow-gaging stations and (inset) graph showing mean monthly streamflows for water year (WY) 2007 for selected USGS streamflow-gaging stations, Blue River watershed, Colorado. 
form the basis of the Climax Mine, the largest molybdenum mine in the world (Gilliland, 2006). Except for molybdenum, the mining industry in the Tenmile Creek subwatershed ended by the late 1950s (Widmann and others, 2004). Mining activity in the Snake River subwatershed began in 1863 with the discovery of Colorado's first major silver lode at Saints John Creek. Extensive and rich silver deposits fueled the mining boom in the upper Snake River subwatershed. Many of the silver deposits contained large percentages of lead and zinc; some also contained gold and iron. Major mining locations included the Montezuma mining area and the Peru Creek watershed. Ore deposits in the Peru Creek watershed yielded gold, which was rare in the Montezuma district (Gilliland, 2006). The historic Pennsylvania Mine, a consolidated group of lodes along Peru Creek yielding gold, silver, lead, copper, and zinc, was operational through the mid-1940s (Gilliland, 2006). Many historical structures and sites related to mining are located throughout the Blue River watershed upstream from Dillon Reservoir. Mining activity in the upper Blue River watershed has resulted in closed and abandoned mines and associated environmental effects.

\section{Methods of Data Review and Analysis}

Methods of data review and analysis of water-quality data for the Blue River watershed included retrieving all water-quality data from the electronic water-quality database for the Blue River watershed, subsetting the data, performing quality-assurance checks, summarizing the data statistically in tables and spatially in figures, analyzing and interpreting analytical data to determine water-quality conditions and characteristics, conducting temporal trend analysis, and comparing data to State of Colorado and Federal water-quality standards and guidelines. The following discussion describes methods used to process, evaluate, and interpret water-quality data for the Blue River watershed.

\section{Data Sources}

The dataset used in this study consists of data for the Blue River watershed collected and reported by various Federal, State, and local agencies, academic institutions, environmental consulting firms, and a ski resort. These data sources include the USGS; the U.S. Environmental Protection Agency (USEPA); the Colorado Department of Natural Resources; the Colorado Department of Public Health and Environment (CDPHE); the Colorado Department of Transportation; the Colorado Division of Wildlife; Breckenridge Sanitation District; Denver Water Board; Northwest Colorado Council of Governments; Summit Water Quality Committee (SWQC); Summit County Environmental Health Department; Colorado State University Department of Fish, Wildlife, and Conservation Biology; University of Colorado Institute of Arctic and Alpine Research; Adrian Brown Consultants, Inc.; American Geological Services;
Hydrosphere Resource Consultants, Inc.; and Arapahoe Basin Ski Resort. Data were obtained in an electronic format from the USGS National Water Information System, USEPA STOrage and RETrieval (STORET) Data Warehouse, and local sources and were merged to form the Blue River watershed water-quality database (http://rmgsc.cr.usgs.gov/cwqdr/ Blue/index.shtml). The database contains water-quality properties and constituents for surface-water (stream, lake, and reservoir), groundwater (wells, springs, and seeps), mining (mine drainage and tailings ponds), and outfall/effluent (wastewater treatment plant output and other point discharge) sampling sites. The data analysis and other information presented in this report focus on 33 different properties and constituents for stream, reservoir, and groundwater sites. At more than onehalf of the stream and reservoir sites and almost all groundwater sites, fewer than six samples were collected. In some instances, data were collected at a particular location by more than one agency, with each agency using its own site numbers or identification systems and naming conventions. These data were combined under one site identification number and name; the USGS site identification number and name were used when available. Instantaneous streamflow, daily mean streamflow, and stream stage data were compiled for several USGS water-quality stations (http://waterdata.usgs.gov/co/nwis/qw).

The greatest number of surface-water-quality samples were collected in the Snake River subwatershed; and the fewest number were collected in the Tenmile Creek subwatershed (table 2). Overall, the CDPHE collected the greatest number of surface-water-quality samples throughout the entire Blue River watershed followed by the SWQC and USGS, respectively (Appendix 3). The SWQC collected at least 31.5 percent of the nutrient samples in each subwatershed. All suspended-sediment samples were collected by the USGS. Almost all (99 percent) of the total-coliform samples were collected by the CDPHE or the Denver Water Board.

\section{Data Quality Assurance}

A number of quality-assurance procedures were applied to the water-quality data prior to analysis. The USEPA has established low and high values for 190 common water-quality constituents and properties as an edit-checking procedure for data entered into STORET since November 1993 (U.S. Environmental Protection Agency, 1977). Low and high values for 62 constituents used in the analysis of data for this report are shown in Appendix 4; data were checked against these values. Some data greater than the USEPA high values were deleted; for example, a dissolved-oxygen concentration of 469 milligrams per liter (mg/L). Trace-element data greater than the high values were not deleted. Trace-element data can occur in high concentrations in the Blue River watershed because of historical mining activities. Some data within the USEPA low and high ranges were deleted because a value was abnormally low or high for a particular site. A specific conductance value of 1.4 microsiemens per centimeter at 25 degrees Celsius (henceforth $\mu \mathrm{S} / \mathrm{cm}$ ), for example, was deleted for a 


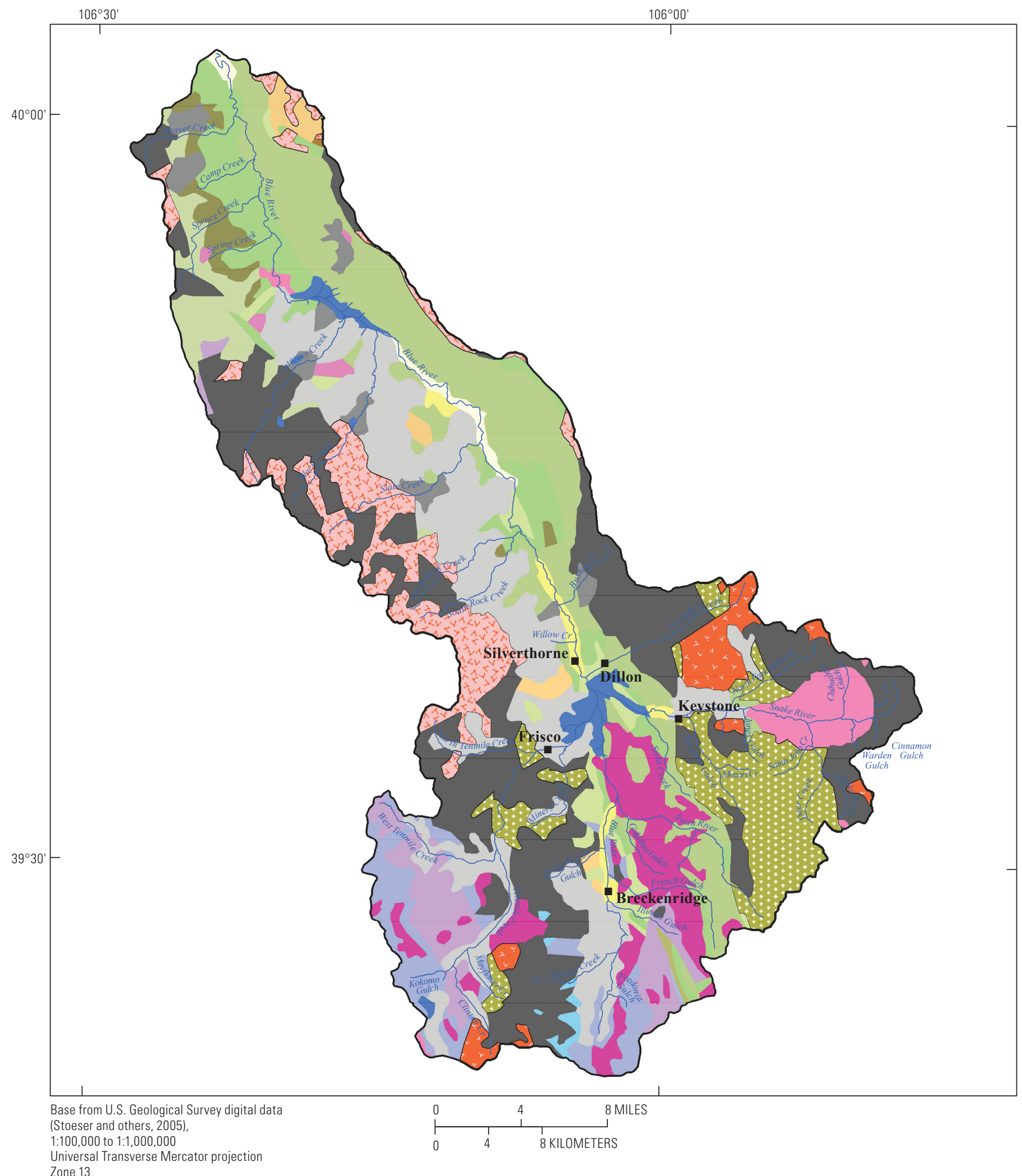

Figure 4. Geology of the Blue River watershed, Colorado. 


\section{EXPLANATION}

Quaternary modern alluvium

Quaternary gravels and alluvium

Quaternary glacial drift of Pinedale and Bull Lake Glaciations

Quaternary older glacial drifts

Quaternary landslide deposits

Tertiary Dry Union Formation

Tertiary Troublesome Formation-sandstone and siltstone

Tertiary Coalmont Formation

Middle Tertiary intrusive rocks

Tertiary volcanic rocks

Tertiary Laramide intrusive rocks

Cretaceous Pierre Shale, undivided

Cretaceous Colorado Group

Cretaceous Dakota Sandstone

Cretaceous Dakota and Morrison Formations

Cretaceous and Jurassic Dakota, Burro Canyon, Morrison, Wanakah, and Entrada Formations

Jurassic Morrison Formation

Triassic Chinle Formation

Pennsylvanian Maroon Formation

Pennsylvanian Minturn Formation

Pre-Pennsylvanian Paleozoic Leadville, Williams Canyon, and Manitou Limestones and Sawatc

Precambrian biotite gneiss, schist, and migmatite

Precambrian felsic and hornblende gneisses

Precambrian granitic rocks of 1,400 mega-annum

Precambrian granitic rocks of 1,700 mega-annum

Waterbody

particular site because all other specific conductance data were greater than $301 \mu \mathrm{S} / \mathrm{cm}$. For a given sample with filtered- and unfiltered-concentration data, the filtered concentration was checked against the unfiltered concentration. If the filtered concentration was greater than the unfiltered concentration by more than 10 percent, both data values were deleted. A filtered (dissolved) water sample has been passed through a 0.45-micrometer-pore-size encapsulated filter. An ion charge balance was calculated for individual samples with sufficient data (hydrogen ion, calcium, magnesium, sodium, potassium, alkalinity, chloride, and sulfate concentrations) to calculate the ion charge balance. A sample was deleted if the charge balance was greater than 10 percent. Using these quality-control procedures, about 306 individual data values out of more than 10,000 were deleted.

For a large portion of the data, limited metadata and(or) quality-assurance data were available. Therefore, it is possible that some data may contain errors that were not detected during the quality-assurance review. Assumptions regarding water-quality collection methods and laboratory-analytical techniques used on data from different data sources were made based on available information. No distinctions between water-quality data collection methods and laboratory analytical techniques were made when metadata were unavailable to support these distinctions. Disparities between data from different sources resulting from differences in water-quality collection methods and laboratory-analytical techniques may affect the precision and accuracy of the statistical results. Although the effect of methodological differences could not be quantified in this analysis, robust statistical methods were used to limit the effects of outliers on the statistical results of the analysis.

\section{Data Compilation and Comparison}

Nutrient data were compiled from the various sources, each with differing laboratory methods and sampling and reporting conventions. For data analysis, equivalent nitrogen and equivalent phosphorus species were combined using data aggregation methods described by Mueller and others (1995) and summarized in table 3 . Concentration data for the first constituent listed in each constituent group were preferred for analysis. If these data were not available, data for the second constituent listed were used. This aggregation continued for each constituent in a constituent group. In combining data for each constituent group under a single constituent name, the data aggregation procedure reduced the number of aggregated nutrient constituents to six and resulted in the creation of a nutrientanalysis dataset that includes the following constituents:

- Total ammonia nitrogen, as nitrogen (hereinafter referred to as "total ammonia")

- Nitrite nitrogen, as nitrogen (hereinafter referred to as "nitrite")

- Nitrate nitrogen, as nitrogen (hereinafter referred to as "nitrate")

- Total nitrogen, as nitrogen (hereinafter referred to as "total nitrogen")

- Orthophosphate, as phosphorus (hereinafter referred to as "orthophosphate")

- Total phosphorus, as phosphorus (hereinafter referred to as "total phosphorus").

In natural waters, nitrogen as ammonia can be in the form of aqueous ammonia (un-ionized ammonia, $\mathrm{NH}_{3}$ ) or ammonium $\left(\mathrm{NH}_{4}^{+}\right)$. At $\mathrm{pH}$ 9.24, the transformation of un-ionized ammonia to ammonium ions is half complete. In most natural water ( $\mathrm{pH}$ less than 9.24), nitrogen as ammonia would be in the ammonium form (Hem, 1992). The term "total ammonia" is used throughout this report to denote the concentration of unionized ammonia and ammonium ions together in a sample. Nutrient data for surface-water sites also includes un-ionized ammonia concentrations, which are values in the Blue River database calculated from water temperature, $\mathrm{pH}$, the concentration of the ammonium ion, and an equilibrium constant. 
Table 2. Number of stream sites and samples with water-quality data by subwatershed or watershed and constitutent group, Blue River watershed, Colorado, October 1995 through December 2006.

[No., number. Number of sites and samples does not include sites and samples with discharge data only]

\begin{tabular}{|c|c|c|c|c|c|c|c|c|}
\hline \multirow{2}{*}{ Constitutent group } & \multicolumn{6}{|c|}{ Subwatershed } & \multirow{2}{*}{\multicolumn{2}{|c|}{$\begin{array}{c}\text { Watershed } \\
\text { Lower Blue River }\end{array}$}} \\
\hline & \multicolumn{2}{|c|}{ Snake River } & \multicolumn{2}{|c|}{ Upper Blue River } & \multicolumn{2}{|c|}{ Tenmile Creek } & & \\
\hline Major ions & 88 & 707 & 39 & 497 & 15 & 142 & 27 & 413 \\
\hline Nutrients & 35 & 619 & 38 & 485 & 13 & 284 & 28 & 758 \\
\hline Trace elements & 88 & 724 & 40 & 552 & 14 & 144 & 27 & 340 \\
\hline Total unique sites and samples & 148 & 1,635 & 51 & 1,200 & 19 & 459 & 33 & 1,143 \\
\hline
\end{tabular}

Table 3. Summary of procedures used to aggregate nutrient data into constituent groups, Blue River watershed, Colorado.

$[\mathrm{N}$, nitrogen; $\mathrm{mg} / \mathrm{L}$, milligram per liter; *, parameter computed from procedure listed for nitrite, as $\mathrm{N}$; **, parameter computed from procedure listed for nitrate, as $\mathrm{N}$; $\mathrm{P}$, phosphorus; $\mathrm{PO}_{4}$, orthophosphate. Total ammonia is the sum of un-ionized ammonia $\left(\mathrm{NH}_{3}\right)$ and ammonium $\left(\mathrm{NH}_{4}^{+}\right)$. A filtered (dissolved) water sample has been passed through a 0.45-micrometer-pore-size encapsulated filter. Aggregation procedures from Mueller and others, 1995]

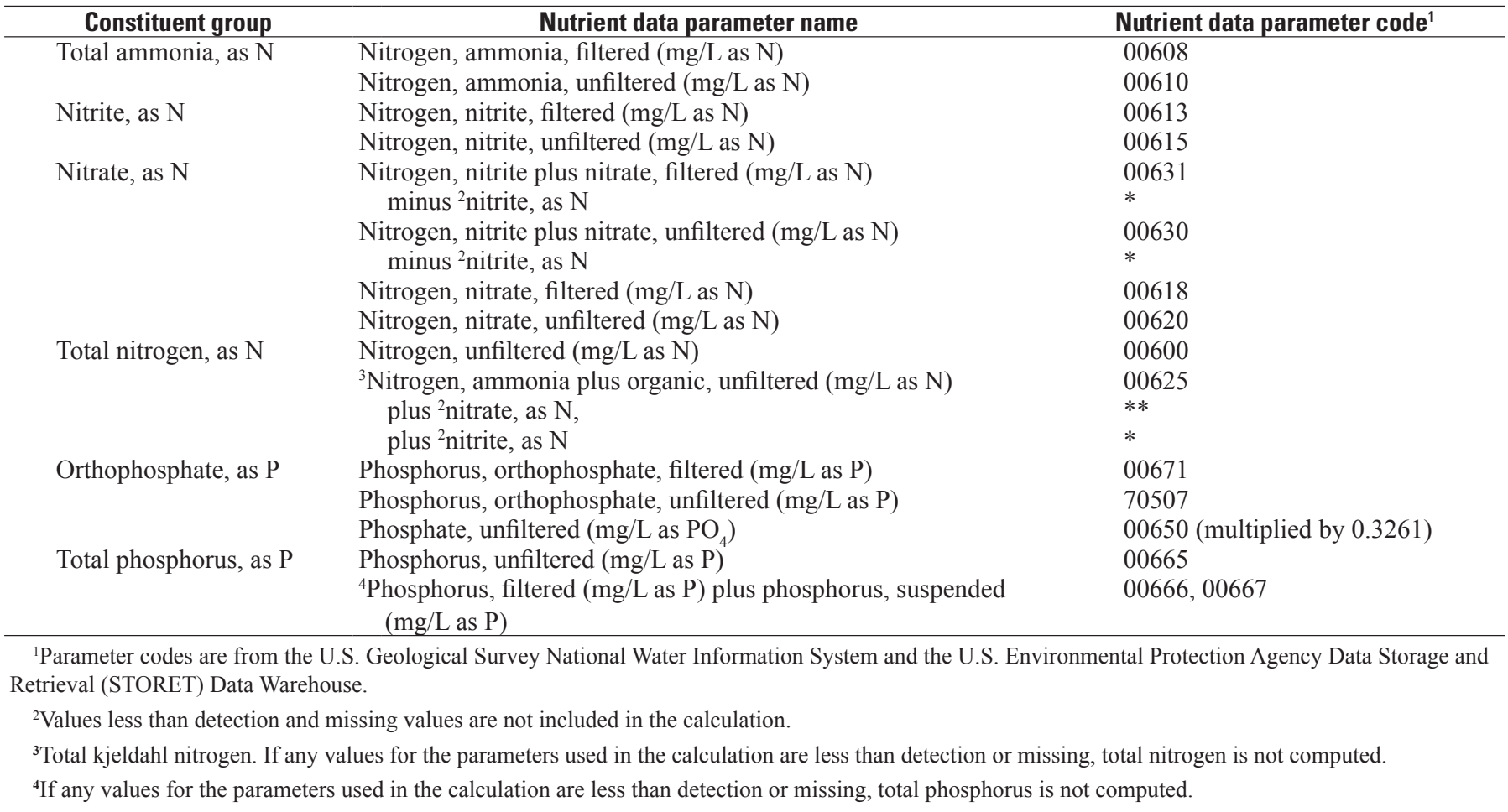

\section{Censored Values}

Computation of summary statistics for water-quality data was complicated by the presence of multiple laboratory reporting levels for constituents not detected during laboratory analysis. Such data are described as censored values and are commonly referred to as "nondetections" or being "less than" a particular laboratory reporting level. A single constituent can have more than one laboratory reporting level, as reporting conventions and analytical procedures change.
For a given constituent with censored values, estimates of percentile values, including the 50th percentile or median, were calculated using the Kaplan-Meier, adjusted maximum likelihood estimation (AMLE), or regression of ordered statistics (ROS) methods following the recommendations of Helsel (2005). The Kaplan-Meier method was used when less than 50 percent of the data were censored values. When censoring percentages were 50 to 80 percent, the ROS method was used for less than 50 samples and for more than 50 samples when the distribution of data was not normal. For data with a normal 
distribution and 50 or more samples, the AMLE method was used. When 80 percent or more of the data were censored values, only the minimum and maximum values are given in summary tables. The estimated percentiles were used to provide median values for spatial distribution maps of selected physical properties and chemical constituents in stream water.

\section{Water-Quality Standards}

Water-quality standards for surface water (streams and reservoirs) and groundwater in Colorado have been established by the CDPHE to protect the beneficial uses of the water (Colorado Department of Public Health and Environment, 2007, 2008c, 2008d, 2009). Standards for streams and reservoirs are discussed first, followed by groundwater.

Numeric standards for various physical properties and chemical and biological constituents are applied on a statewide basis to stream segments and water bodies based on wateruse classification. Specific standards discussed in this report are for protection of cold-water aquatic life and domestic water-supply and recreation uses. Standards for many properties and constituents are fixed values. This includes dissolved oxygen, $\mathrm{pH}$, chloride, sulfate, nitrite, nitrate, and Escherichia coli (E. coli). Standards for other properties and constituents, including water temperature, total ammonia, and metals, are calculated values known as table value standards (TVS). Two types of TVSs have been adopted for total ammonia and metals: acute and chronic. An acute standard is the level not to be exceeded by the concentration of a single sample or the average concentration of all samples collected during a 1-day period; the chronic standard is the level not to be exceeded by a single representative sample or the average of all samples collected during a 30-day period (Colorado Department of Public Health and Environment, 2008c). Water-quality standards have not been adopted for all properties or constituents.

The CDPHE has adopted water-quality standards for the protection of aquatic life for dissolved oxygen and $\mathrm{pH}$ (Colorado Department of Public Health and Environment, 2008c, 2008d). In reservoirs, the dissolved-oxygen standard of $6.0 \mathrm{mg} / \mathrm{L}$ applies to the epilimnion and metalimnion layers during thermal stratification. The $\mathrm{pH}$ standard of 6.5-9.0 applies to all streams in the Blue River watershed with the exception of Soda Creek in the Snake River subwatershed. The $\mathrm{pH}$ standard for this stream is 6.0-9.0.

Water temperature standards for the Blue River watershed are based on the cold-water aquatic-life classification "cold stream tier one" or "CS-I" (Colorado Department of Public Health and Environment, 2008d). Two types of temperature standards have been adopted: the Daily Maximum (DM) and the Maximum Weekly Average Temperature (MWAT). The DM is the highest 2-hour average water temperature recorded during a given 24-hour period and is applied as the acute standard. The MWAT is the maximum average of multiple, equally spaced, daily temperatures over seven consecutive days with a minimum of three data points spaced equally through each day, and is calculated from the optimum and upper temperatures tolerated by a species (Colorado Department of Public Health and Environment, 2008c). The MWAT is applied as the chronic standard. Different numeric acute and chronic standards have been adopted for June-September and October-May for streams and January-March and April-December for the larger (surface area greater than 100 acres) lakes and reservoirs. For streams in the Blue River watershed, water temperature only was measured when a water-quality sample was collected. These data were insufficient to calculate a DM or MWAT. The individual water temperature values, however, were compared to the DM or acute standard to get an overall impression of a stream's water temperature but were not used to determine compliance to the DM standard.

The CDPHE has adopted domestic water-supply standards of $250 \mathrm{mg} / \mathrm{L}$ for chloride and sulfate (Colorado Department of Public Health and Environment, 2008c, 2008d). These standards apply to surface waters with an actual watersupply use and are based on the 30-day average. For water that is not in use as a water supply, the chloride and sulfate standards can be used in a general way to evaluate water quality. For purposes of this report, the chloride and sulfate standards were compared to dissolved and total concentrations. The USEPA has recommended a secondary water-quality standard of $500 \mathrm{mg} / \mathrm{L}$ for total dissolved solids in drinking water (U.S. Environmental Protection Agency, 2008a). A secondary standard is a nonenforceable guideline for contaminants that may have cosmetic (skin or tooth discoloration), esthetic (such as taste, odor, and color), or technical (corrosion and staining) effects.

The CDPHE has established acute and chronic TVSs for total ammonia (un-ionized ammonia concentrations plus ammonium ions) that are based on the aquatic-life classification for cold-water biota (Colorado Department of Public Health and Environment, 2008c, 2008d). The acute TVS is a function of stream $\mathrm{pH}$ at the time of sample collection and specific fish species. The chronic TVS is the criterion established by the CDPHE for the early life stages of fish and is a function of stream $\mathrm{pH}$ and temperature at the time of sample collection. The total ammonia standards will vary along a stream reach as $\mathrm{pH}$ and temperature change. The water-quality standard for nitrite of $0.05 \mathrm{mg} / \mathrm{L}$ has been adopted by the CDPHE for the protection of aquatic life. A domestic watersupply standard of $10 \mathrm{mg} / \mathrm{L}$ of nitrate has been adopted by the CDPHE. This is based on the 1-day average. The CDPHE has not adopted a water-quality standard for total phosphorus in streams. The USEPA, however, has recommended that total phosphorus concentrations be less than $0.1 \mathrm{mg} / \mathrm{L}$ for streams that do not flow directly into lakes and reservoirs and less than $0.05 \mathrm{mg} / \mathrm{L}$ for streams that flow directly into lakes and reservoirs to control eutrophication (elevated nutrient concentrations and excessive algal growth) of the water bodies (U.S. Environmental Protection Agency, 1986). For Dillon Reservoir, a total phosphorus standard of $0.0074 \mathrm{mg} / \mathrm{L}$ for unfiltered water in the top 15 meters $(\mathrm{m})(49.21 \mathrm{ft})$ of the 
water column for the months July through October has been adopted by the CDPHE (Colorado Department of Public Health and Environment, 2007).

Water-quality standards for the protection of aquatic life have been established by the CDPHE for trace elements (Colorado Department of Public Health and Environment, 2008c, 2008d). Aquatic-life standards for dissolved cadmium, copper, lead, manganese, nickel, silver, and zinc are hardness-dependent TVSs; standards for dissolved and total recoverable arsenic, dissolved chromium VI and selenium, total mercury, and total recoverable iron are fixed numeric values. No aquatic-life standards have been adopted for aluminum and uranium in the Blue River watershed (Colorado Department of Public Health and Environment, 2008d). Uranium, a radiochemical, is included with trace elements for purposes of this report. Hardness-dependent TVSs are calculated using site-specific hardness values. The hardness values used in calculating the standard are "based on the lower 95th percent confidence limit of the mean hardness value at low-flow criteria as determined from a regression analysis of site-specific data" (Colorado Department of Public Health and Environment, 2008c). For this report, low-flow data represent samples collected from October through March. When five or more hardness values were available for a site during the low-flow period, the lower 95 th percent confidence limit of the mean hardness value was used in calculating the TVS standard. If fewer than five low-flow hardness values were available, the mean of the values was used in the TVS equation. When no low-flow hardness values existed and five or more hardness values were available for non-low-flow samples, all hardness values were used to calculate the lower 95th percent confidence limit of the mean hardness. If fewer than five hardness values were available for non-low-flow samples, the mean hardness for the samples was used in calculating the TVS standard. For sites with no hardness data, hardness values from nearby sites were used in the TVS equation. The CDPHE has established domestic water-supply use standards for dissolved iron and manganese that are fixed values based on 30-day averages (Colorado Department of Public Health and Environment, 2008c).

The presence of $E$. coli bacteria in water indicates that the water may be contaminated with human or animal wastes. The CDPHE has adopted water-quality standards for E. coli in surface water that are based on recreational use of water (Colorado Department of Public Health and Environment, 2008c, 2008d). Stream segments in the Blue River watershed have one of three recreation classifications: "Recreation E," primary contact use; "Recreation P," potential primary contact use; and "Recreation N," no primary contact use. Most segments are "Recreation E." Numeric standards for these classes are 126 colonies per 100 milliliters $(\mathrm{col} / 100 \mathrm{~mL})$, $205 \mathrm{col} / 100 \mathrm{~mL}$, and $630 \mathrm{col} / 100 \mathrm{~mL}$, respectively. Compliance with these values is based on geometric means of at least five samples collected over a 30-day period. For this report, an insufficient number of $E$. coli bacteria samples was collected to calculate geometric means for comparison to the standards for regulatory purposes. However, data for E. coli can be used as a general indication of water quality in streams where the bacteria are present.

Water-quality standards for physical properties, major ions, nutrients, trace elements, and total coliform bacteria in groundwater have been established by the CDPHE based on use of the water (Colorado Department of Public Health and Environment, 2009). Numeric standards are available for domestic water supply (human health standards and drinkingwater standards) and agricultural supply. Additional standards for total dissolved solids depend on background total dissolved-solids concentration. Data for groundwater wells in the Blue River watershed were compared to the domestic water-supply standards.

\section{Temporal Trend Analysis}

Temporal trend analysis was conducted on selected physical properties and constituents for surface-water sites to identify changes in water quality over time. In this study, trend analyses were performed using the nonparametric seasonal Kendall trend (SKT) test (Hirsch and others, 1982; Helsel and Hirsch, 2002). The test measures for a monotonic relation between concentration and time. A monotonic trend is one in which a concentration consistently decreases and never increases or consistently increases and never decreases over a particular time period. Because there are strong seasonal variations in water-quality concentrations, the SKT test accounts for seasonality by calculating the Mann-Kendall test on each season separately, then combining the results for all seasons. For quarterly "seasons," for example, January-March data are compared only with January-March, April-June with April-June, and so forth. If there were more increases than decreases in a constituent concentration over time, a positive relation was identified. A trend was determined to be present when the p-value of the statistical test was less than the alpha level of 0.05 . The smaller the p-value, the stronger the evidence is to reject the null hypothesis that no trend exists (Helsel and Hirsch, 2002). For censored data, one-half the censored value was used in the tests. The trend slope is an estimate of the yearly change in value or concentration for the tested time period and is presented as a percentage of the mean value or concentration per year. Trend results differ depending on the time period used in the trend analysis. Trends that are identified for a particular constituent at a site for one time period may not be identified when another time period is used. In trends testing, there is greater uncertainty when short time periods are analyzed.

\section{Trophic State Index}

A common method to describe the biological condition of a lake or reservoir is trophic state. Trophic state is defined by Carlson and Simpson (1996) as the total weight of living biological material in a reservoir at a particular time and 
place. It indicates productivity, which is the rate of formation of living material, primarily algae, in a water body averaged over a defined period of time (Wetzel, 1983). Oligotrophic lakes or reservoirs have low nitrogen and phosphorus concentrations and limited production of organic material. Mesotrophic reservoirs have moderate concentrations of nitrogen and phosphorus and increased production of organic material. Eutrophic reservoirs have high concentrations of nutrients and high production of organic material. With increased productivity or eutrophication, there is increased algal growth and decreased water clarity. Low dissolved-oxygen conditions can develop. The trophic status of a reservoir can be computed using a trophic state index. Three numeric indices are used in this report: total phosphorus, chlorophyll- $a$, and Secchi disk transparency. Because trophic state is a continuum and different scales are used for the indices, the trophic class of a water body may differ depending on the index used. Chlorophyll- $a$ is the preferred index because it most accurately predicts algal biomass (Carlson and Simpson, 1996). Trophic state indices are used in this report to give a qualitative indication of the state of a reservoir at a particular time and assess changes over time with time-series plots.

\section{Surface-Water Quality}

This section summarizes physical properties and water quality for selected streams and reservoirs in the Blue River watershed. General information on physical properties and water-quality constituents are presented first, followed by detailed analyses of data for physical properties, major ions, nutrients, trace elements, suspended sediment, and coliform bacteria for streams, and physical properties, suspended solids, nutrients, and chlorophyll- $a$ for Dillon and Green Mountain Reservoirs.

\section{Overview of Physical Properties and Water-Quality Constituents}

Water temperature affects the rate and equilibria of chemical reactions and metabolic rates of aquatic organisms (Allan, 1996). Temperature in surface water is dependent on such factors as season, elevation, streamflow, and plant shading. In reservoirs, water temperature is especially dependent on solar radiation and wind (Wetzel, 1983). Dissolved oxygen is essential to the health and survival of biota in water bodies. Oxygen also affects biogeochemical processes; some processes such as the release of phosphorus and iron from reservoir sediments occur during anoxic conditions. Dissolved-oxygen concentrations depend on such factors as photosynthesis (releases dissolved oxygen) and respiration (consumes dissolved oxygen), depth of water, proximity to the atmosphere, elevation, atmospheric and barometric pressure, and water temperature. Specific conductance is the ability of a substance to conduct an electric current. Specific conductance itself is not a health or environmental concern but is an indicator of the amount of dissolved solids in water. High specific conductance values can be attributed to natural and anthropogenic sources of dissolved solids. The source of most dissolved solids in water is the mineral assemblage in rocks near the land surface. As rocks are weathered, water flowing across and through rocks will dissolve soluble minerals and chemically react with other minerals, releasing dissolved solids to the water (Hem, 1992). Irrigation can accelerate the movement of agricultural chemicals to streams and increase dissolution of minerals. The $\mathrm{pH}$ of surface water can affect the health and survival of biota, the chemical form of constituents in a stream such as ammonium $\left(\mathrm{NH}_{4}^{+}\right)$or un-ionized ammonia $\left(\mathrm{NH}_{3}\right)$, and the solubility of trace elements. In most streams, $\mathrm{pH}$ ranges from 6.5 to 8.5 (Hem, 1992). Diurnal fluctuations in $\mathrm{pH}$ result when organisms take up dissolved carbon dioxide by photosynthesis during the day and release carbon dioxide by respiration at night (Hem, 1992). Geology and soils can release acid and alkaline constituents to water that affect $\mathrm{pH}$. The $\mathrm{pH}$ decreases in the presence of sulfide-bearing minerals in rocks and soils as water and oxygen react with sulfur to form sulfuric acid (Hem, 1992). This can occur naturally in areas with mineralized bedrock or in areas with hard-rock mining. Weathering of calcite in rocks and soils increases bicarbonate and carbonate concentrations in water, resulting in increased $\mathrm{pH}$ and alkalinity (U.S. Environmental Protection Agency, 1997). Alkalinity (determined on a filtered sample) and acid neutralizing capacity (determined on a whole-water sample) measure the ability of a water sample to neutralize strong acid (Rounds, 2006).

The concentrations of major ions in water, including the cations calcium, magnesium, sodium, and potassium and the anions sulfate, bicarbonate, carbonate, chloride, and fluoride, are dependent on natural and human factors that include surface/groundwater interaction, geology and soils, industrial and mining discharge or waste, and agricultural and road runoff. Concentrations of calcium and magnesium expressed as calcium carbonate $\left(\mathrm{CaCO}_{3}\right)$ determine water hardness. Hardness can affect the toxicity of metals and anthropogenic uses of water (Hem, 1992). Total dissolved solids (also described as dissolved solids) are materials dissolved in water that pass through a filter (usually 0.45 micrometer). Major ions constitute most of the dissolved solids in water. Excessive concentrations of dissolved solids in water can affect aquatic ecosystems and water usage.

Nutrients (nitrogen and phosphorus) occur in different chemical forms, including ammonium $\left(\mathrm{NH}_{4}^{+}\right)$, un-ionized ammonia $\left(\mathrm{NH}_{3}\right)$, nitrate, nitrite, and orthophosphate. Natural sources of nitrogen and(or) phosphorus to water bodies include atmospheric nitrogen, organic material, and phosphorus minerals eroding and dissolving from geologic formations, soils, and sediments. Anthropogenic sources include fertilizer use, wastewater treatment plant effluent, seepage from feedlots and septic systems, phosphate-containing detergents, and atmospheric deposition of nitrogen compounds from fossilfuel combustion. Phosphorus in the particulate form tends to bind to suspended material. Nitrogen and phosphorus are 
essential for plant and animal nutrition, but elevated concentrations in a water body can cause excessive algal and nuisance plant growth (eutrophication). Elevated concentrations of ammonium and un-ionized ammonia can harm fish. Excessive nitrate concentrations in drinking water can cause low blood oxygen levels in infants (U.S. Environmental Protection Agency, 1997).

Trace elements are required by biota in small amounts, but substantial concentrations can be harmful to plants, animals, and humans. Some trace elements can bioaccumulate in biota and bioconcentrate in the food chain (U.S. Geological Survey, 2013). Trace-element type and concentration often are directly related to the bedrock geology and natural geochemical conditions in an area. Streams in mineralized areas naturally can contain high background concentrations of dissolved metals from the oxidation and weathering of pyrite and other sulfide minerals. Common anthropogenic sources of trace elements are atmospheric deposition and mining, industrial, and domestic effluents (Calamari and Naeve, 1994). Historical hard-rock mining in the Blue River watershed upstream from Dillon Reservoir has effected water quality (Apodaca and others, 2000). Many of the metals mined in the watershed, such as gold, copper, and lead, are found in deposits with sulfide-bearing minerals such as pyrite and sphalerite. As water flows through mines and mine waste, it becomes contaminated with dissolved metals that are released from rocks when sulfuric acid is formed from the oxidation of sulfide-bearing minerals. Aquatic biota cannot survive in streams with high metal concentrations.

Uranium is an important indicator of radon gas, a human carcinogen. The potential for radon in indoor air increases with higher concentrations of uranium in rocks. The USEPA has assigned Summit, Grand, and Lake Counties to the radon-potential category of 1 , the highest potential for elevated indoor radon levels (U.S. Environmental Protection Agency, 2012).

Suspended solids (typically called suspended sediment) are very fine particles suspended in water for a significant time period without settling. This includes silt and soil from erosion and storm and urban runoff, remains from the breakdown of terrestrial and aquatic biota, and wastes from industry and water treatment plants. The amount and size of suspended solids in water are affected by streamflow; higher flows in streams can carry more and larger suspended material than lower flows.

Fecal coliform bacteria, including E. coli, are an indication of the sanitary quality of the surface water and the potential for adverse human-health effects (U.S. Environmental Protection Agency, 1997). These bacteria themselves usually do not cause illness; instead, they can indicate the presence of more harmful bacteria.

Chlorophyll- $a$, the primary photosynthetic pigment in algae, is used during photosynthesis to convert sunlight into organic compounds. As such, chlorophyll- $a$ concentrations can be used as indicators of primary production and trophic state
(Boyer, 2009). High concentrations of chlorophyll- $a$ in a water body can indicate nutrient enrichment as excess nutrients are used for chlorophyll- $a$ growth.

\section{Streams}

Analysis of stream data focuses primarily on data collected by 15 agencies (Appendix 3) from October 1995 through December 2006 rather than on all stream data in the Blue River water-quality database (data collected from June 1957 through December 2006). Analyzing data for 1995 through 2006 presents a more accurate picture of the current state of the watershed than analyzing all data collected since 1957. Data for individual constituents may be available for shorter time periods than October 1995 through December 2006. Values of $\mathrm{pH}$ in the Tenmile Creek subwatershed, for example, were measured from November 1995 through June 2005. A total of 251 stream sites are included in the water-quality data analysis. More than onehalf (132 of 251) of the sites had five or fewer samples collected from October 1995 through December 2006. Sites with six or more samples or exceedances of trace-element standards are shown in figure 5 and listed in Appendix 1. Site names in Appendix 1 are from the Blue River water-quality database; site names used in the report are nonabbreviated versions of those in Appendix 1.

Data for the subwatersheds (Snake River, upper Blue River, and Tenmile Creek) and lower Blue River watershed are analyzed and discussed separately. Each has unique geologic and water-quality characteristics. Summary tables of data for each subwatershed and the lower Blue River watershed are shown in the individual subwatershed and watershed sections. These tables include all 251 stream sites for which water samples were analyzed. Median values of specific conductance and $\mathrm{pH}$ and median concentrations of nitrate, total phosphorus, and dissolved cadmium, copper, manganese, and zinc are illustrated on spatial distribution maps for sites with six or more samples collected on separate days from October 1995 through December 2006, and with latitude and longitude values in the database. Concentration ranges are shown by colors. Data for sites with five or fewer samples have similar values and concentrations as those shown on the spatial distribution maps for sites with six or more samples. Data for each subwatershed and the lower Blue River watershed were compared to applicable water-quality standards established by the CDPHE (Colorado Department of Public Health and Environment, 2008c, 2008d) and selected USEPA guidelines and recommendations (U.S. Environmental Protection Agency, 2008a) to provide a context for the existing water quality. The water-quality standards discussed include those for protection of aquatic life, drinking-water supply, and recreational use. Exceedances of trace-element water-quality standards for protection of aquatic life are illustrated spatially. These sites are included in figure 5 and Appendix 1. 


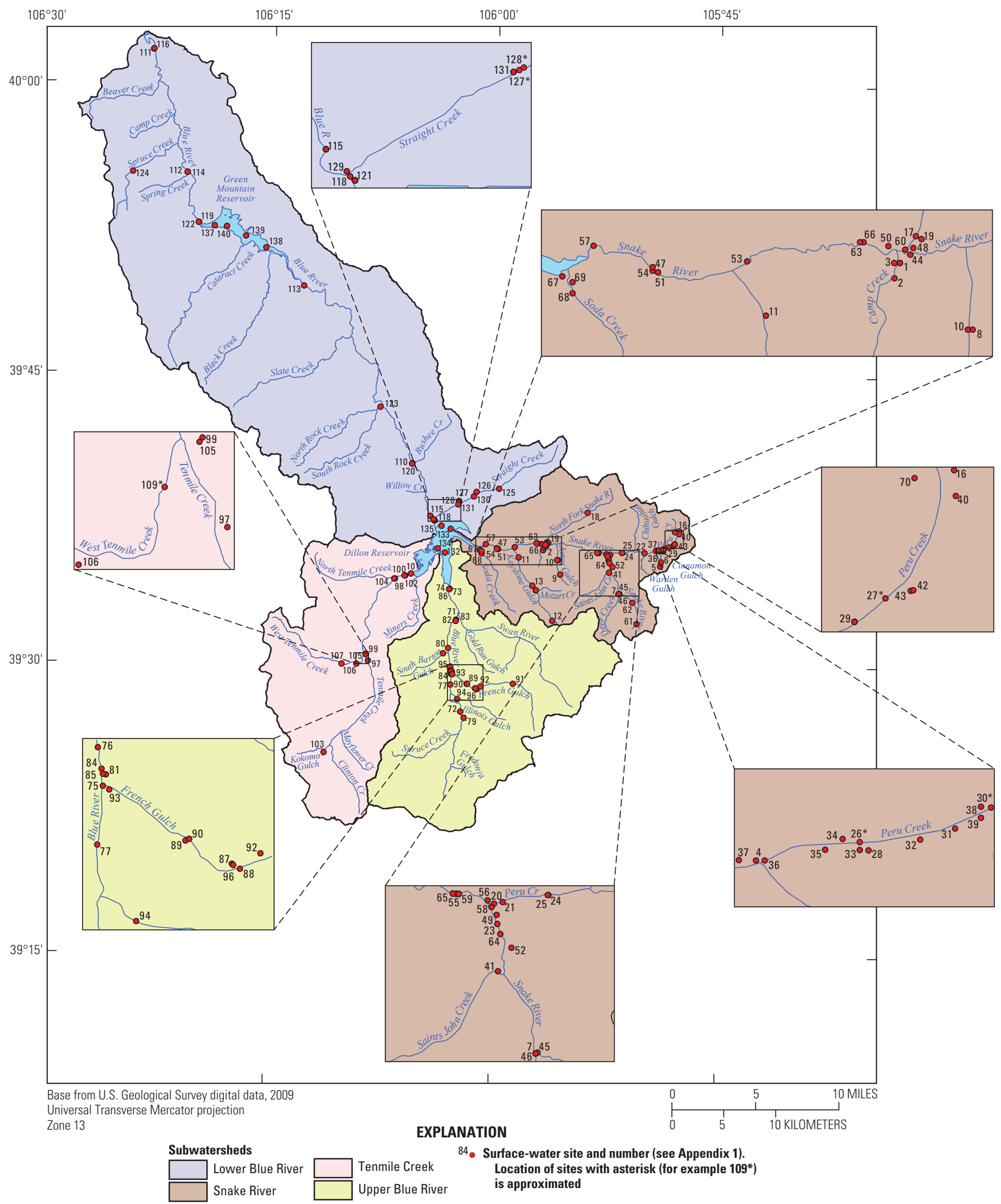

Figure 5. Location of suface-water sites with six or more water-quality samples or exceedances of Colorado Department of Public Health and Environment trace-element water-quality standards for the protection of aquatic life or domestic water supply, Blue River watershed, Colorado. 
For each subwatershed and the lower Blue River watershed, the number of stream sites with water-quality data for the constituent groups (physical properties, major ions, nutrients, trace elements, suspended sediment, and coliform bacteria) and the number of samples are shown in table 2 , along with the total number of sites and samples with waterquality data. All constituents in a constituent group in the database are included in table 2 , not just the constituents that are discussed in this report. The greatest number of sites sampled and samples collected were in the Snake River subwatershed; the fewest were in the Tenmile Creek subwatershed. For each subwatershed and the lower Blue River watershed, sampling occurred most often during May through July, the months with the highest streamflow, followed by August through October (table 4).

All sites and constituents were considered for possible temporal trend analysis. No stream sites had adequate data to analyze any water-quality constituent for temporal trends because of data requirements for statistical trend analysis. Requirements for statistical trend analysis include at least quarterly sample collection for 5 or more years, less than 5 percent censored values, 20 percent or more of the data in one-third of the overall time period when the period of record is divided into thirds, and a relatively fixed schedule of data collection with sufficient samples collected during the beginning and end of the analysis period (Schertz and others, 1991). Cadmium, manganese, and zinc were collected monthly at French Gulch at Breckenridge (site 93) and data were not censored but samples were collected for just 4 years. With short time periods, it is difficult to separate trends in data from natural variability. Four years of data are too few to have confidence in trend results. Before 1996, most total phosphorus data were censored at high levels $(0.01,0.02$, or $0.05 \mathrm{mg} / \mathrm{L})$ and were not suitable for trend analysis. For many sites, samples were collected every year between 1985 (the beginning year for trend analysis) and 1995 and then sampled every other year. With this pattern, less than 20 percent of the data were collected in the last one-third of the period of record. For Blue River below Dillon, CO (site 118), specific conductance data were available from 1985 through 2005. Measurements were generally taken monthly between 1985 and 2001 and during 2003 but less frequently (6 months or less) during 2002, 2004, and 2005. The number of samples decreased substantially at the end of the analysis period. Data used in this analysis of water quality in the Blue River watershed were collected by numerous agencies and entities with different sampling plans and purposes for sample collection. Data were not specifically collected for trend analysis, and limitations in the data that were compiled (length of data record, censoring, data gaps) prevented trend analysis of stream-water-quality data.

\section{Snake River Subwatershed}

In the Blue River water-quality database, water-quality data for the Snake River subwatershed were available for 148 sites and 1,635 samples (table 2). Of these sites and samples, data on physical properties were available for 135 sites and 1,454 samples (table 2). Water temperatures measured during sample collection at stream sites in the subwatershed ranged between -2.1 and $19.8^{\circ} \mathrm{C}$ (table 5). About 28 percent (142 of 513) of the temperature values measured between October and May were greater than the CDPHE acute aquaticlife water-quality standard of $13.0^{\circ} \mathrm{C}$ for those months. Most (139 of 142) of these values were measured between late April and the end of May 2000 at 12 sites in the Keystone Gulch area. The remaining (3 of 142) values that exceeded the standard were measured in early October 1996. Except for these limited time periods in 1996 and 2000, water temperature values were less than the acute standard for the protection of cold-water aquatic life. Almost all (230 of 233) dissolvedoxygen concentrations were greater than or equal to $6.0 \mathrm{mg} / \mathrm{L}$, the minimum dissolved-oxygen concentration established by the CDPHE for protection of aquatic life.

One or more specific conductance measurements were made at 94 sites in the Snake River subwatershed (table 5). Most (95 percent) specific conductance values were less than $300 \mu \mathrm{S} / \mathrm{cm}$; and about 46 percent were less than $100 \mu \mathrm{S} / \mathrm{cm}$. Specific conductance values are generally low in the Snake River subwatershed because igneous rocks in the subwatershed are fairly resistant to the solvent action of water, and sedimentary rock formations mostly are absent. Median specific conductance values for most tributaries to the Snake River were less than $200 \mu \mathrm{S} / \mathrm{cm}$ (fig. 6). The highest median specific conductance value of $349 \mu \mathrm{S} / \mathrm{cm}$ was measured at the Soda Creek at inlet to weir (site 67) site which is located downstream from a wastewater treatment plant. Soda Creek flows directly into Dillon Reservoir.

Table 4. Total number of water-quality samples collected per season by subwatershed or watershed, Blue River watershed, Colorado, October 1995 through December 2006.

[Number of samples per season does not include discharge data]

\begin{tabular}{lcccc}
\hline \multirow{2}{*}{ Subwatershed or watershed } & \multicolumn{3}{c}{ Number of samples per season } \\
\cline { 2 - 5 } & November-January & February-April & May-July & August-0ctober \\
\hline Snake River subwatershed & 205 & 198 & 839 & 393 \\
Upper Blue River subwatershed & 186 & 200 & 464 & 167 \\
Tenmile Creek subwatershed & 69 & 81 & 351 & 142 \\
Lower Blue River watershed & 209 & 270 & 313 \\
\hline
\end{tabular}


Table 5. Summary of the number of samples and sites, minimum, median, and maximum values, and Colorado Department of Public Heath and Environment in-stream water-quality standards for stream-water samples in the Snake River subwatershed, Blue River watershed, Colorado, 1995 through 2006.

[No., number; ${ }^{\circ} \mathrm{C}$, degrees Celsius; $\mathrm{mg} / \mathrm{L}$, milligrams per liter; $\mu \mathrm{S} / \mathrm{cm}$, microsiemens per centimeter at 25 degrees Celsius; --, no standard; $\mathrm{CaCO}_{3}$, calcium carbonate; $<$, less than; $\mathrm{ft}^{3} / \mathrm{s}$, cubic feet per second; $\mathrm{HCO}_{3}^{-}$, bicarbonate; DWS, domestic water supply; ne, no exceedance; N, nitrogen; nc, not computed; TVS, table value standard; P, phosphorus; $\mu \mathrm{g} / \mathrm{L}$, micrograms per liter; col/100 mL, colonies per $100 \mathrm{milliliters.} \mathrm{Water-}$ quality standards are from Colorado Department of Public Health and Environment (2008c, 2008d) unless otherwise noted; standards are for protection of aquatic life unless otherwise stated. Standards may not apply to every site where data were collected. See table 6 for additional information on water-quality standards for trace elements]

\begin{tabular}{|c|c|c|c|c|c|c|c|c|}
\hline $\begin{array}{l}\text { Property or constituent } \\
\text { (reporting units) }\end{array}$ & $\begin{array}{l}\text { No. of } \\
\text { samples/ } \\
\text { no of } \\
\text { censored } \\
\text { values }\end{array}$ & $\begin{array}{l}\text { No. of } \\
\text { sites }\end{array}$ & $\begin{array}{l}\text { Minimum } \\
\text { value }\end{array}$ & $\begin{array}{l}\text { Median } \\
\text { value }\end{array}$ & $\begin{array}{l}\text { Maximum } \\
\text { value }\end{array}$ & $\begin{array}{l}\text { In-stream } \\
\text { water-quality } \\
\text { standard }\end{array}$ & $\begin{array}{c}\text { No. of sites with } \\
\text { measurement or } \\
\text { concentration greater } \\
\text { than censoring limit that } \\
\text { do not meet } \\
\text { water-quality standard }\end{array}$ & $\begin{array}{l}\text { No. of samples with } \\
\text { measurement or } \\
\text { concentration greater } \\
\text { than censoring limit } \\
\text { that do not meet } \\
\text { water-quality standard }\end{array}$ \\
\hline \multicolumn{9}{|c|}{ Physical properties } \\
\hline Temperature $\left({ }^{\circ} \mathrm{C}\right)$ & $938 / 1$ & 84 & $1-2.1$ & 8.0 & 19.8 & $\begin{array}{c}\text { June-September, } 21.2^{\circ} \mathrm{C} ;{ }^{2} \\
\text { October-May, } 13.0^{\circ} \mathrm{C}\end{array}$ & $\begin{array}{c}14 \text { (acute, } \\
\text { October-May) }\end{array}$ & $\begin{array}{l}142 \text { (acute, } \\
\text { October-May) }\end{array}$ \\
\hline Oxygen, dissolved (mg/L) & $233 / 0$ & 23 & 4.4 & 9.0 & 16.2 & 6.0 & 3 & 3 \\
\hline Specific conductance $(\mu \mathrm{S} / \mathrm{cm})$ & $1,212 / 0$ & 94 & 19 & 105 & 575 & -- & -- & -- \\
\hline $\mathrm{pH}$, field (standard units) & $1,022 / 0$ & 119 & 2.1 & 7.0 & 10.3 & ${ }^{3} 6.0-9.0,6.5-9.0$ & 85 & 316 \\
\hline Acid neutralizing capacity $\left(\mathrm{mg} / \mathrm{L}\right.$ as $\left.\mathrm{CaCO}_{3}\right)$ & $208 / 16$ & 45 & $<2$ & 20 & 85 & -- & -- & -- \\
\hline Discharge, annual mean $\left(\mathrm{ft}^{3} / \mathrm{s}\right)$ & $411 / 0$ & ${ }^{5} 1$ & 36.9 & 92.7 & 149.5 & -- & -- & -- \\
\hline \multicolumn{9}{|c|}{ Major ions } \\
\hline Bicarbonate, dissolved (mg/L as $\mathrm{HCO}_{3}^{-}$) & $124 / 7$ & 31 & $<2$ & 26 & 100 & -- & -- & -- \\
\hline Calcium, dissolved $(\mathrm{mg} / \mathrm{L})$ & $385 / 1$ & 51 & $<1$ & 13.2 & 148 & -- & -- & -- \\
\hline Chloride, dissolved $(\mathrm{mg} / \mathrm{L})$ & $160 / 75$ & 37 & $<1$ & $<1$ & 26 & ${ }^{3} 250$ DWS or none & ne & ne \\
\hline Magnesium, dissolved (mg/L) & $387 / 1$ & 51 & $<0.5$ & 2.86 & 73.3 & - & -- & -- \\
\hline Sulfate, dissolved $(\mathrm{mg} / \mathrm{L})$ & $234 / 3$ & 40 & $<5$ & 42.0 & 150 & ${ }^{3} 250$ DWS or none & ne & ne \\
\hline Sulfate, total $(\mathrm{mg} / \mathrm{L})$ & $118 / 36$ & 12 & $<1$ & $<10$ & 75 & ${ }^{3} 250$ DWS or none & ne & ne \\
\hline Dissolved solids (mg/L) & $217 / 0$ & 24 & 36 & 90 & 310 & ${ }^{6} 500$ & ne & ne \\
\hline Hardness $(\mathrm{mg} / \mathrm{L})$ & $573 / 0$ & 53 & 1.6 & 42 & 140 & -- & -- & -- \\
\hline \multicolumn{9}{|c|}{ Nutrients } \\
\hline Total ammonia (mg/L as N) & $246 / 214$ & 19 & $<0.002$ & $\mathrm{nc}^{7}$ & $<0.2$ & TVS & ne & ne \\
\hline Un-ionized ammonia (computed, $\mathrm{mg} / \mathrm{L}$ as $\mathrm{N}$ ) & $8 / 0$ & 3 & 0.000 & $<0.001$ & 0.002 & -- & -- & -- \\
\hline Nitrite $(\mathrm{mg} / \mathrm{L}$ as $\mathrm{N})$ & $57 / 54$ & 14 & $<0.01$ & $\mathrm{nc}^{7}$ & $<0.05$ & 0.05 & ne & ne \\
\hline Nitrate (mg/L as N) & $316 / 30$ & 21 & $<0.0013$ & 0.139 & ${ }^{8} 20$ & ${ }^{3} 10$ DWS or none & 1 & 11 \\
\hline Nitrogen, total (mg/L as N) & $14 / 0$ & 9 & 0.17 & 0.44 & ${ }^{9} 14.6$ & -- & -- & -- \\
\hline Orthophosphate (mg/L as P) & $246 / 4$ & 8 & 0 & 0.002 & 0.375 & -- & -- & -- \\
\hline Phosphorus, total (mg/L as P) & $512 / 147$ & 25 & $<0.001$ & 0.017 & 0.40 & ${ }^{10} 0.05,0.1$ & 7 & 19 \\
\hline \multicolumn{9}{|c|}{ Trace elements } \\
\hline Aluminum, dissolved $(\mu \mathrm{g} / \mathrm{L})$ & $419 / 93$ & 57 & $<3$ & 33.2 & ${ }^{11} 9,900$ & -- & -- & -- \\
\hline Arsenic, dissolved $(\mu \mathrm{g} / \mathrm{L})$ & $236 / 225$ & 33 & $<0.05$ & $\mathrm{nc}^{7}$ & $<6$ & 340 (acute) & ne & ne \\
\hline Arsenic, total recoverable $(\mu \mathrm{g} / \mathrm{L})$ & $32 / 28$ & 16 & $<1$ & $\mathrm{nc}^{7}$ & 2 & ${ }^{3} 0.02,7.6$ (chronic) & ne & ne \\
\hline Cadmium, dissolved $(\mu \mathrm{g} / \mathrm{L})$ & $514 / 146$ & 66 & $<0.1$ & 1.10 & ${ }^{12} 619$ & TVS $^{13}$ & 47 & 350 \\
\hline Chromium, dissolved ( $\mu \mathrm{g} / \mathrm{L})$ & $61 / 60$ & 21 & $<0.2$ & $\mathrm{nc}^{7}$ & $<2.2$ & TVS (16 acute, 11 chronic) & ne & ne \\
\hline Copper, dissolved $(\mu \mathrm{g} / \mathrm{L})$ & $561 / 187$ & 67 & $<0.5$ & 4.00 & ${ }^{14} 11,060$ & TVS $^{13}$ & 44 & 231 \\
\hline Iron, dissolved $(\mu \mathrm{g} / \mathrm{L})$ & $523 / 94$ & 64 & $<1$ & 49.6 & ${ }^{15} 129,800$ & ${ }^{3} 300$ DWS or no DWS & 5 & 20 \\
\hline Iron, total recoverable $(\mu \mathrm{g} / \mathrm{L})$ & $515 / 31$ & 67 & $<10$ & 210 & 18,600 & 1,000 (chronic) & 14 & 31 \\
\hline Lead, dissolved $(\mu \mathrm{g} / \mathrm{L})$ & $412 / 278$ & 63 & $<0.1$ & 0.21 & 47.8 & $\mathrm{TVS}^{13}$ & 32 & 86 \\
\hline Manganese, dissolved $(\mu \mathrm{g} / \mathrm{L})$ & $605 / 79$ & 67 & $<2$ & 245 & 1696,000 & TVS, ${ }^{12} 350$ DWS or no DWS & 12 TVS, 28 DWS & 43 TVS, 303 DWS \\
\hline
\end{tabular}


Table 5. Summary of the number of samples and sites, minimum, median, and maximum values, and Colorado Department of Public Heath and Environment in-stream water-quality standards for stream-water samples in the Snake River subwatershed, Blue River watershed, Colorado, 1995 through 2006.-Continued

[No., number; ${ }^{\circ} \mathrm{C}$, degrees Celsius; $\mathrm{mg} / \mathrm{L}$, milligrams per liter; $\mu \mathrm{S} / \mathrm{cm}$, microsiemens per centimeter at 25 degrees Celsius; --, no standard; $\mathrm{CaCO}_{3}$, calcium carbonate; $<$, less than; $\mathrm{ft}^{3} / \mathrm{s}$, cubic feet per second; $\mathrm{HCO}_{3}^{-}$, bicarbonate; DWS, domestic water supply; ne, no exceedance; N, nitrogen; nc, not computed; TVS, table value standard; P, phosphorus; $\mu \mathrm{g} / \mathrm{L}$, micrograms per liter; col/100 mL, colonies per 100 milliliters. Waterquality standards are from Colorado Department of Public Health and Environment (2008c, 2008d) unless otherwise noted; standards are for protection of aquatic life unless otherwise stated. Standards may not apply to every site where data were collected. See table 6 for additional information on water-quality standards for trace elements]

\begin{tabular}{|c|c|c|c|c|c|c|c|c|}
\hline $\begin{array}{l}\text { Property or constituent } \\
\text { (reporting units) }\end{array}$ & $\begin{array}{l}\text { No. of } \\
\text { samples/ } \\
\text { no of } \\
\text { censored } \\
\text { values }\end{array}$ & $\begin{array}{l}\text { No. of } \\
\text { sites }\end{array}$ & $\begin{array}{l}\text { Minimum } \\
\text { value }\end{array}$ & $\begin{array}{c}\text { Median } \\
\text { value }\end{array}$ & $\begin{array}{l}\text { Maximum } \\
\text { value }\end{array}$ & $\begin{array}{c}\text { In-stream } \\
\text { water-quality } \\
\text { standard }\end{array}$ & $\begin{array}{c}\text { No. of sites with } \\
\text { measurement or } \\
\text { concentration greater } \\
\text { than censoring limit that } \\
\text { do not meet } \\
\text { water-quality standard }\end{array}$ & $\begin{array}{l}\text { No. of samples with } \\
\text { measurement or } \\
\text { concentration greater } \\
\text { than censoring limit } \\
\text { that do not meet } \\
\text { water-quality standard }\end{array}$ \\
\hline \multicolumn{9}{|c|}{ Trace elements-Continued } \\
\hline Mercury, total $(\mu \mathrm{g} / \mathrm{L})$ & $167 / 165$ & 31 & $<0.1$ & $\mathrm{nc}^{7}$ & $<0.2$ & 0.01 & 2 & 2 \\
\hline Nickel, dissolved $(\mu \mathrm{g} / \mathrm{L})$ & $128 / 7$ & 27 & $<1.0$ & 4.43 & 26 & TVS $^{13}$ & ne & ne \\
\hline Selenium, dissolved $(\mu \mathrm{g} / \mathrm{L})$ & $225 / 106$ & 33 & $<0.2$ & $\mathrm{nc}^{7}$ & 21.7 & TVS ( 18.4 acute, 4.6 chronic) & 7 & 11 \\
\hline Silver, dissolved $(\mu \mathrm{g} / \mathrm{L})$ & $232 / 228$ & 32 & $<0.02$ & $\mathrm{nc}^{7}$ & $<5.3$ & TVS $^{13}$ & 4 & 4 \\
\hline Uranium, natural, dissolved $(\mu \mathrm{g} / \mathrm{L})$ & $23 / 22$ & 6 & $<1$ & $\mathrm{nc}^{7}$ & $<3$ & 1730 & ne & ne \\
\hline Zinc, dissolved $(\mu \mathrm{g} / \mathrm{L})$ & $588 / 33$ & 69 & $<2$ & 300 & ${ }^{18} 101,000$ & TVS $^{3,12}$ & 53 & 412 \\
\hline \multicolumn{9}{|c|}{ Suspended sediment } \\
\hline Suspended sediment $(\mathrm{mg} / \mathrm{L})$ & $15 / 0$ & 3 & 0.2 & 4 & 49 & -- & -- & -- \\
\hline \multicolumn{9}{|c|}{ Coliform bacteria } \\
\hline Total coliform (col/100 mL) & $11 / 0$ & 1 & 10 & 22 & 130 & -- & -- & -- \\
\hline Fecal coliform (col/100 mL) & $23 / 21$ & 7 & $<3$ & $\mathrm{nc}^{7}$ & 9 & -- & -- & -- \\
\hline Escherichia coli (col/100 mL) & $29 / 0$ & 8 & 0 & 0 & 56.3 & $3,19126,630$ & ne & ne \\
\hline
\end{tabular}

${ }^{1}$ Minimum value does not include one value censored at less than $0.7^{\circ} \mathrm{C}$.

${ }^{2}$ Acute temperature standard (Colorado Department of Public Health and Environment, 2008c).

${ }^{3}$ Standard varies by stream segment. See Colorado Department of Public Health and Environment (2008d).

${ }^{4}$ Water years 1996-2006. A water year is a 12-month period beginning October 1 and ending September 30 of the following year. A water year is designated as the year in which it ends.

${ }^{5}$ Snake River near Montezuma, CO (USGS site number 09047500).

${ }^{6}$ USEPA secondary drinking-water standard, nonenforceable guideline. See U.S. Environmental Protection Agency (2008a).

${ }^{7}$ Eighty percent or more of data were censored values. Median value could not be computed.

${ }^{8}$ Maximum value does not include one value censored at greater than $11.4 \mathrm{mg} / \mathrm{L}$

${ }^{9}$ Next highest value was $1.24 \mathrm{mg} / \mathrm{L}$.

${ }^{10} \mathrm{USEPA}-$ recommended concentration limits for total phosphorus to control eutrophication in downstream water bodies; $0.05 \mathrm{mg} / \mathrm{L}$ is for streams that flow directly into lakes and reservoirs, $0.1 \mathrm{mg} / \mathrm{L}$ is for streams that do not flow directly into lakes and reservoirs (U.S. Environmental Protection Agency, 1986).

${ }^{11}$ Extreme value. Next highest value was $6,500 \mu \mathrm{g} / \mathrm{L}$

${ }^{12}$ Extreme value. Next highest value was $20 \mu \mathrm{g} / \mathrm{L}$.

${ }^{13}$ Standard varies with hardness. See Colorado Department of Public Health and Environment (2008c).

${ }^{14}$ Extreme value. Next highest value was $290 \mu \mathrm{g} / \mathrm{L}$.

${ }^{15}$ Extreme value. Next highest value was $1,630 \mu \mathrm{g} / \mathrm{L}$

${ }^{16}$ Extreme value. Next highest value was $2,867 \mu \mathrm{g} / \mathrm{L}$

${ }^{17}$ USEPA primary drinking-water standard, enforceable guideline. See U.S. Environmental Protection Agency (2008a).

${ }^{18}$ Extreme value. Next highest value was $2,831 \mu \mathrm{g} / \mathrm{L}$

${ }^{19}$ Standard applies to recreational use. 


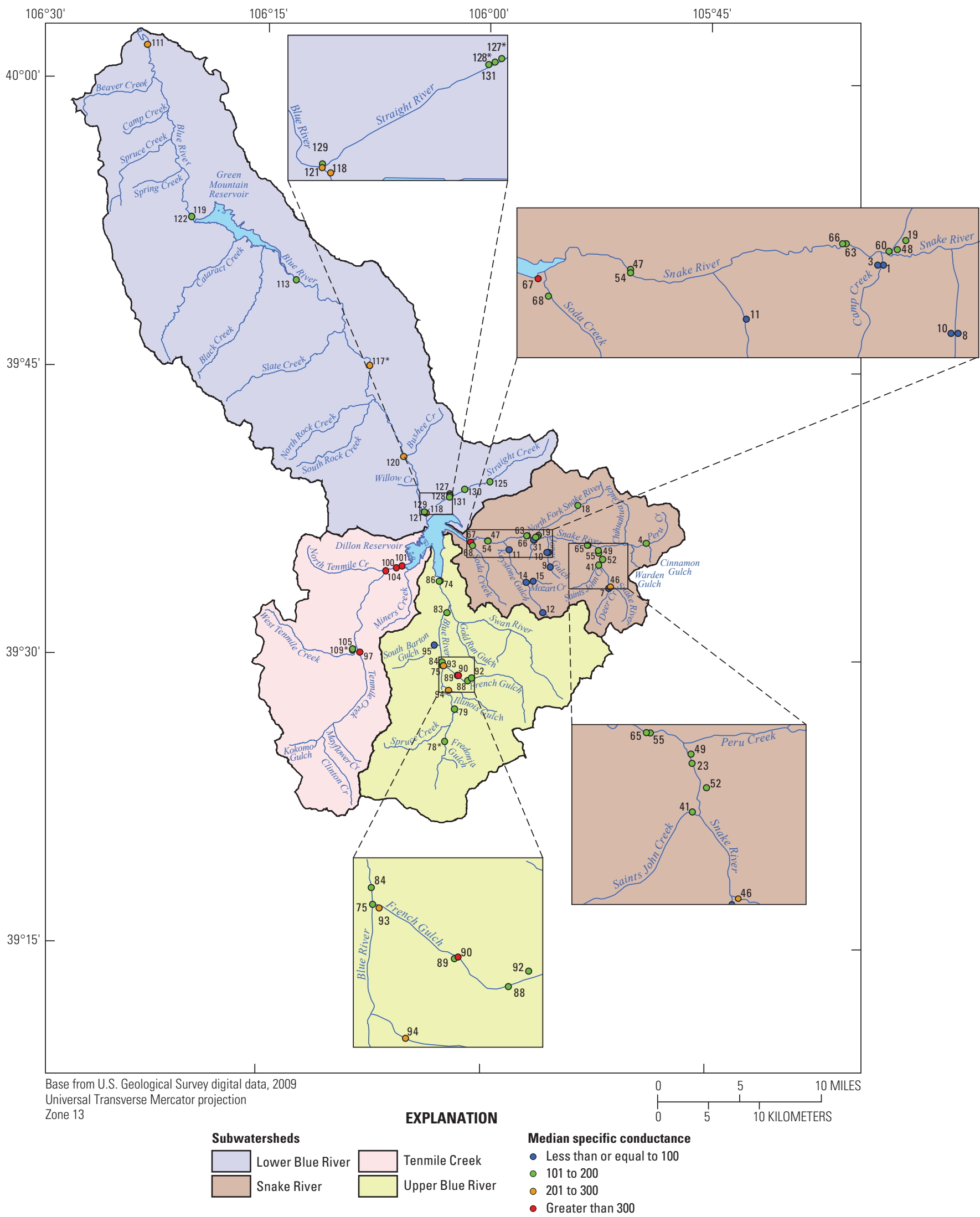

Figure 6. Spatial distribution of median values of specific conductance for selected sites in the Blue River watershed with six or more samples, 1995 through 2006. Number next to symbol is site number referenced in Appendix 1. The location of sites with an asterisk (for example, 109*) is approximated. 
Values of $\mathrm{pH}$ in the Snake River subwatershed ranged from 2.1 to 10.3 in 1,022 samples measured at 119 sites (table 5). Low pH values (less than 5.5) were measured in streams that drained areas with mineralized bedrock and historical hard-rock mining in the headwaters of the upper Snake River and Peru Creek (figs. 1 and 7). The oxidation of sulfidebearing minerals creates sulfuric acid in water, causing low $\mathrm{pH}$ values in water. The upper Snake River is naturally acidic (between 2.1 and 5.5 upstream from the Deer Creek confluence) and metal enriched because of the weathering of disseminated pyrite in the native rock on the eastern side of the basin (Theobald and others, 1963; Boyer and others, 1999). Drainages from mines in the Peru Creek watershed have $\mathrm{pH}$ values between 3 and 5 (McKnight and Bencala, 1990). About 31 percent $(316$ of 1,022$)$ of the $\mathrm{pH}$ values measured in the subwatershed were less than 6.5 , the typical lower bound of the aquatic-life water-quality standard for most streams in the subwatershed (Colorado Department of Public Health and Environment, 2008d). For sites with six or more $\mathrm{pH}$ values, median $\mathrm{pH}$ values less than 6.2 primarily were measured in Peru Creek and the headwaters of the Snake River (fig. 7). Downstream from the confluence of these two streams, median $\mathrm{pH}$ in the Snake River increased with the inflow of tributary water with higher $\mathrm{pH}$, although some individual measurements remained less than the minimum standard of 6.5.

Segments of these two streams, including the main stem of the Snake River and most tributaries and wetlands from the source to Dillon Reservoir and Saints John Creek, and the main stem of Peru Creek and wetlands and tributaries with the exception of Chihuahua Gulch, are on the State of Colorado 2008 303(d) list of impaired waters for nonattainment of aquatic-life use standards for $\mathrm{pH}$ (Colorado Department of Public Health and Environment, 2008a, 2008b). Mayer and Ellersieck (1986) report that trout avoid streams with a $\mathrm{pH}$ less than 6 and cannot survive when stream $\mathrm{pH}$ is less than 5 .

The acid-neutralizing capacity (ANC) at sites in the Snake River subwatershed ranged from less than 2 to $85 \mathrm{mg} / \mathrm{L}$ (table 5). The median ANC was about $7 \mathrm{mg} / \mathrm{L}$ at sites in mined areas of the Snake River subwatershed and $34 \mathrm{mg} / \mathrm{L}$ in the North Fork Snake River, a pristine unmined drainage with low mineralization. Lower values of ANC indicate a reduction in the capacity to neutralize inputs of acidic water; consequently, the addition of acidic drainage to waters with low ANC values can cause a rapid decrease in $\mathrm{pH}$. For water with sufficient buffering capacity (higher ANC), inputs of acidic drainage can be absorbed and neutralized without $\mathrm{pH}$ significantly changing. A total of 180 samples collected at 31 sites in the Snake River subwatershed had data for both ANC and $\mathrm{pH}$. Almost one-quarter (18 of 76) of the samples with a lower buffering capacity (ANC less than 20) had a pH less than 6.5 compared with 2 percent ( 2 of 104) of samples with a higher buffering capacity (ANC between 20 and $85 \mathrm{mg} / \mathrm{L}$ ).

Only 14 samples collected at three sites had adequate major-ion data to determine water type. Two of these sites, Peru Creek at mouth (site 23, one sample) and Snake River below mouth of Peru Creek (site 55, three samples), were located near the headwaters in areas associated with historical mining (fig. 5) or mineralized rock. The third site, Snake River below Keystone (site 54, 10 samples), was located downstream from Keystone in the lower part of the subwatershed (fig. 5). The water type for the two upstream sites that were affected by historical mining or mineralized bedrock was a calcium sulfate type (fig. 8), reflecting the weathering of sulfate-bearing minerals associated with historical mining and mineralized lithology. At the downstream Snake River site, the water type was a calcium mixed-sulfatebicarbonate type because of the inflow of water from streams not affected by historical mining or mineralized rock.

All chloride and sulfate concentrations were less than the in-stream domestic water-supply standard of $250 \mathrm{mg} / \mathrm{L}$ established by the CDPHE for each constituent (table 5). Sulfate concentrations varied spatially with the presence or absence of historical mining and sulfate-bearing minerals. All dissolved-solids concentrations were less than the USEPArecommended concentration of $500 \mathrm{mg} / \mathrm{L}$ (U.S. Environmental Protection Agency, 2008a). Hardness values generally were low in the Snake River subwatershed. The maximum hardness value measured at most sites was less than $89 \mathrm{mg} / \mathrm{L}$. The maximum hardness value $(140 \mathrm{mg} / \mathrm{L})$ in the subwatershed was measured in a sample from Soda Creek downstream from Snake River WWTP (site 69). Major-ion and total dissolvedsolids concentrations and hardness values were lower during snowmelt runoff than during low streamflow because of streamflow dilution.

A total of 619 samples were collected for nutrient analysis at 35 sites in the Snake River subwatershed (table 2). Samples were collected most often from the Snake River, followed by Soda Creek, Peru Creek, North Fork Snake River, Deer Creek, Saints John Creek, Keystone Gulch, Jones Gulch, Camp Creek, and Mozart Creek. Total phosphorus samples were collected more often and at more sites than other nutrient constituents, followed by nitrate. A summary of the nutrient data are listed in table 5. The spatial distribution of median nitrate and total phosphorus concentrations are illustrated in figures 9 and 10, respectively, for sites with six or more samples collected from 1995 through 2006.

Total ammonia, un-ionized ammonia, nitrite, and nitrate concentrations were generally well below water-quality standards. Most (87 percent) total ammonia data were censored (table 5). All detected concentrations were less than $0.2 \mathrm{mg} / \mathrm{L}$ (table 5). No concentration was greater than the acute and chronic TVS for total ammonia established by the CDPHE for the protection of aquatic life, which ranged from 2.45 to $39 \mathrm{mg} / \mathrm{L}$ for the acute standard and 1.14 to $7.1 \mathrm{mg} / \mathrm{L}$ for the chronic standard for the Snake River subwatershed. Unionized ammonia concentrations in eight samples collected in 1997 were $0.002 \mathrm{mg} / \mathrm{L}$ or less. Most (95 percent) nitrite data were censored, and the detected concentrations were less than the CDPHE water-quality standard of $0.05 \mathrm{mg} / \mathrm{L}$ for aquaticlife protection. All but one site in the Snake River subwatershed, Soda Creek at inlet to weir (site 67), had median nitrate concentrations equal to or less than $0.50 \mathrm{mg} / \mathrm{L}$ (fig. 9), well below the CDPHE water-quality standard of $10 \mathrm{mg} / \mathrm{L}$ for domestic water supply. Soda Creek at inlet to weir (site 67) 


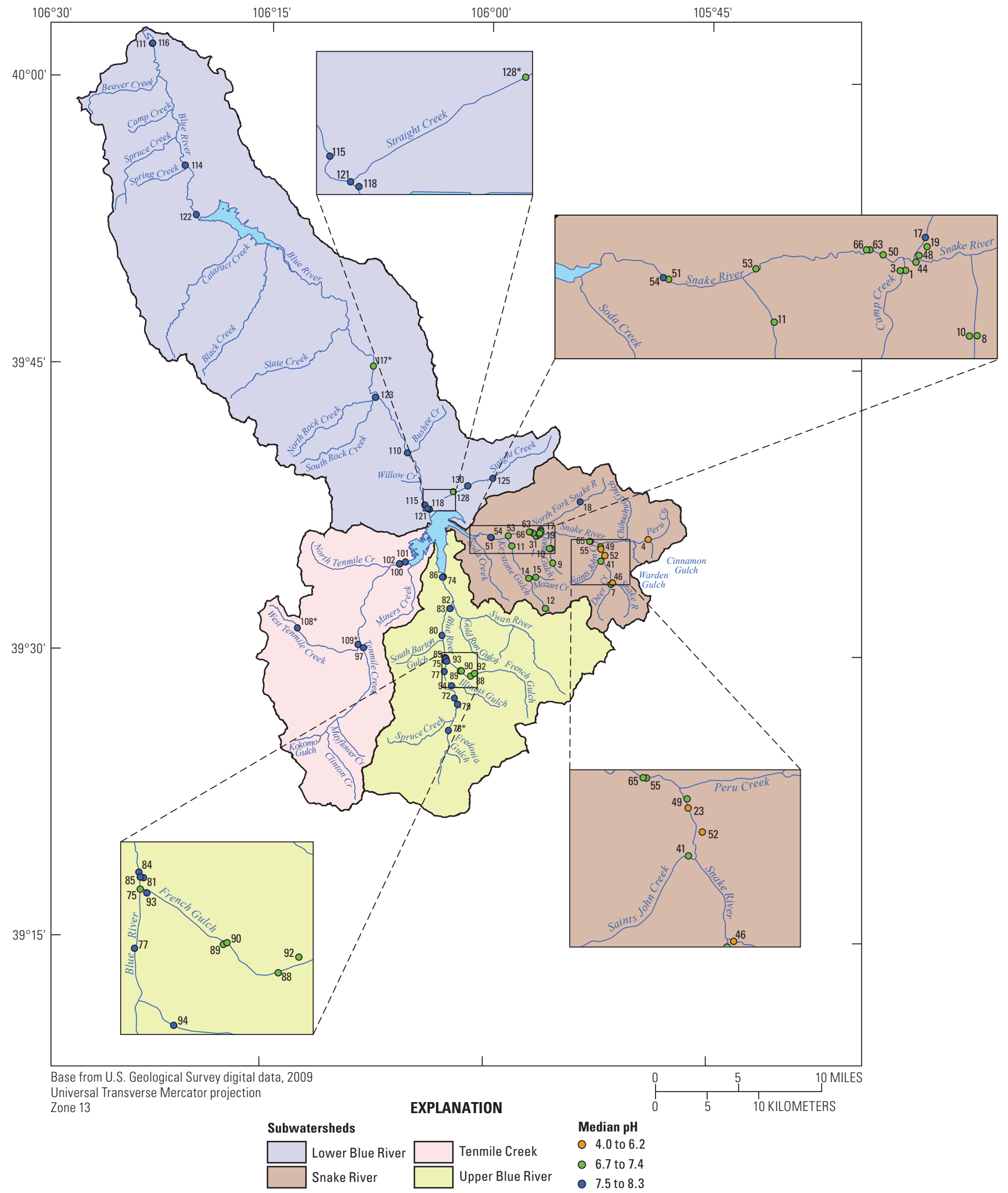

Figure 7. Spatial distribution of median values of $\mathrm{pH}$ for selected sites in the Blue River watershed with six or more samples, 1995 through 2006. Number next to symbol is site number referenced in Appendix 1. The location of sites with an asterisk (for example, 109*) is approximated. 
$\boldsymbol{A}$

Snake River subwatershed

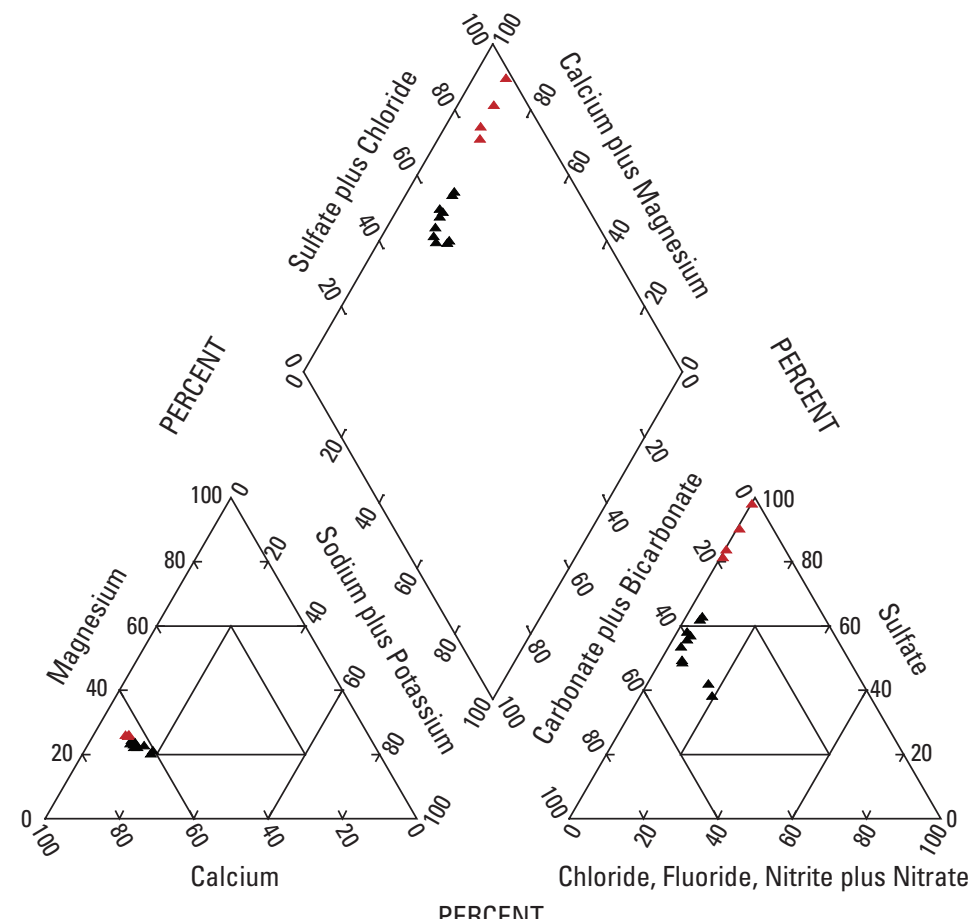

PERCENT
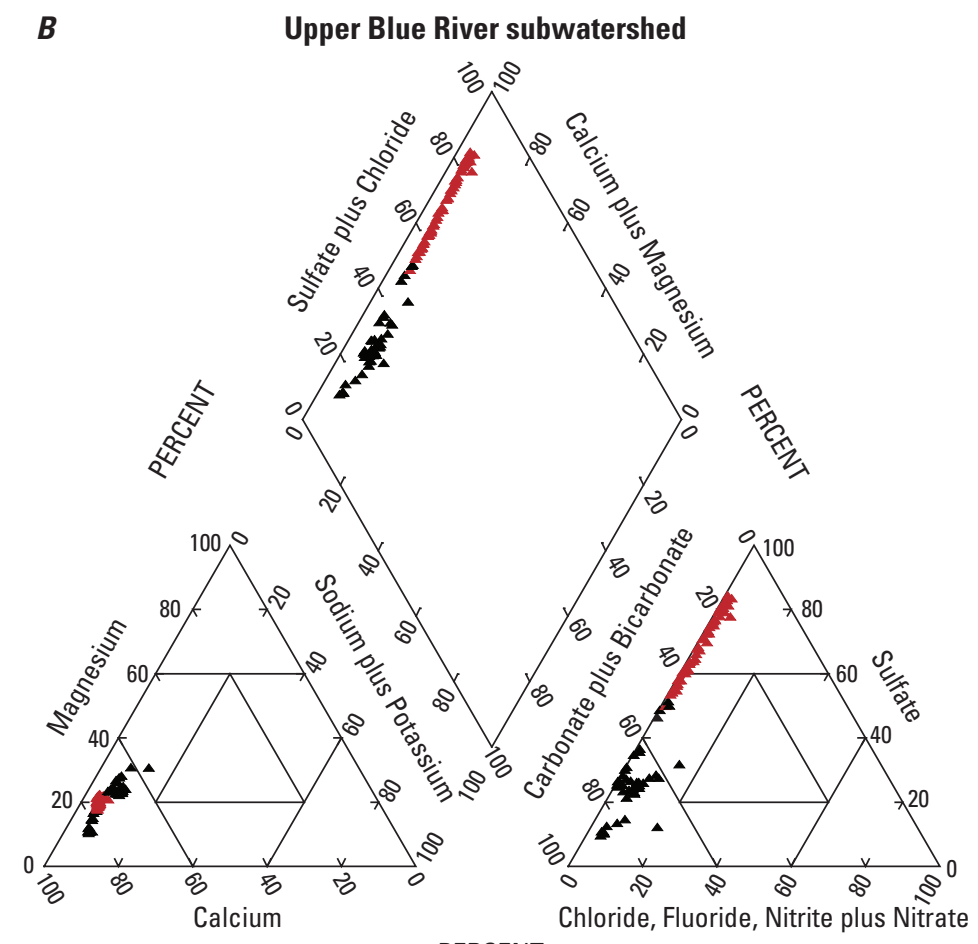

PERCENT

EXPLANATION

$\triangle$ Sites with water type affected by historical mining or mineralized bedrock

- Sites with water type not affected by historical mining or mineralized bedrock

Figure 8. Concentrations of major ions in water from stream sites in the $(A)$ Snake River and $(B)$ upper Blue River subwatersheds with water types affected and not affected by historical mining or mineralized bedrock. All percentages are in milliequivalents per liter. 


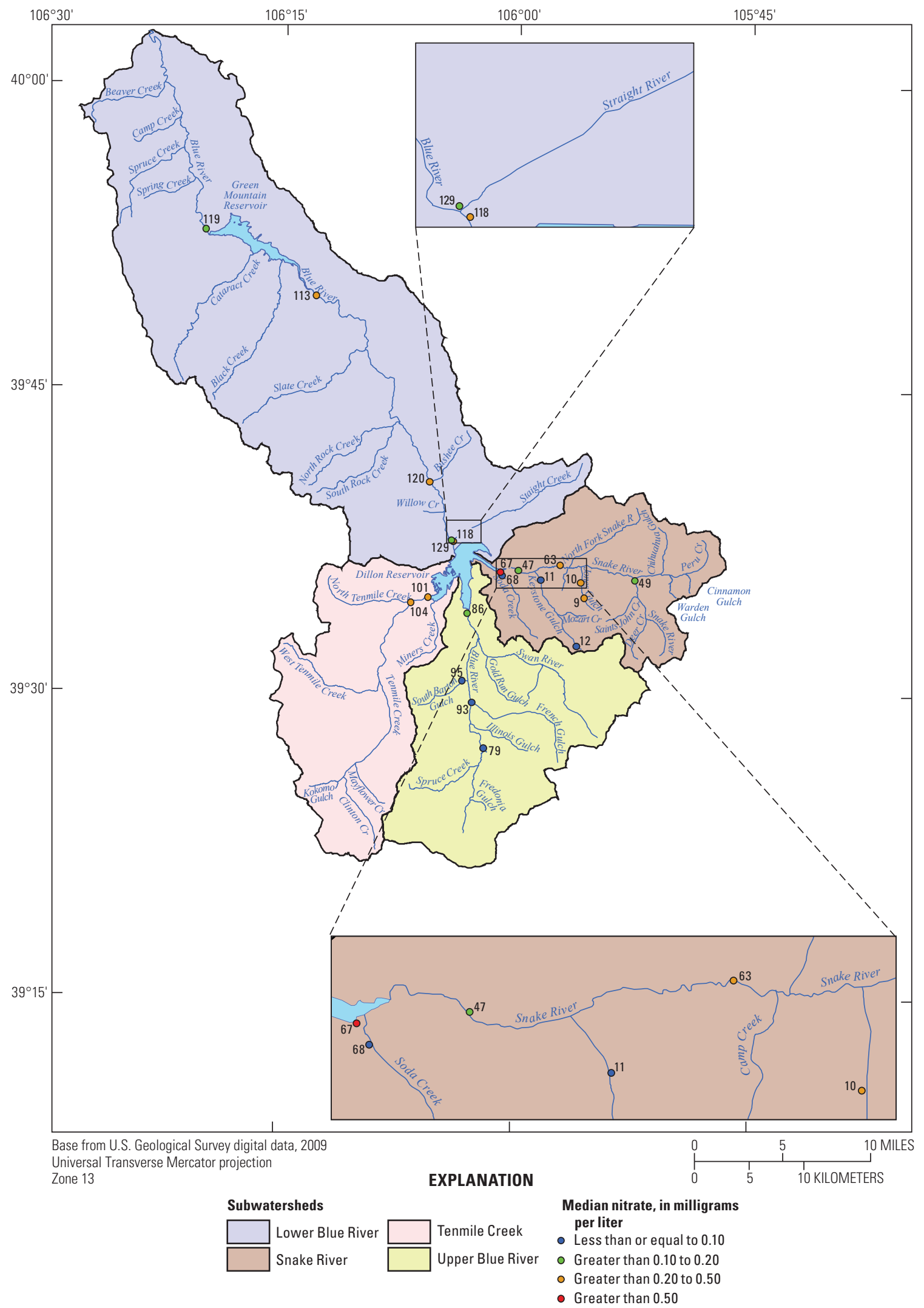

Figure 9. Spatial distribution of median concentrations of nitrate for selected sites in the Blue River watershed with six or more samples, 1995 through 2006. Number next to symbol is site number, referenced in Appendix 1. 


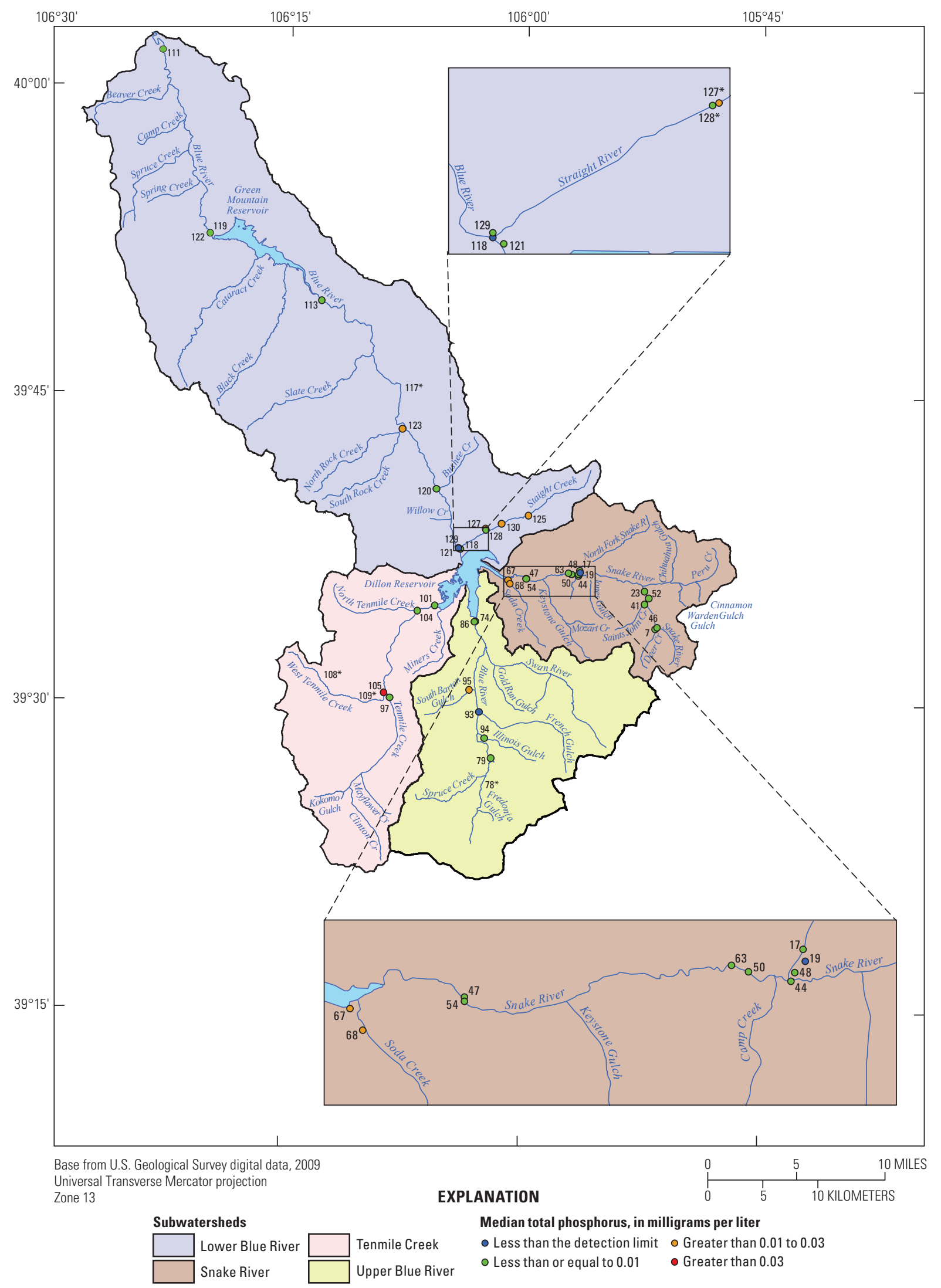

Figure 10. Spatial distribution of median concentrations of total phosphorus for selected sites in the Blue River watershed with six or more samples, 1995 through 2006. Number next to symbol is site number, referenced Appendix 1. The location of sites with an asterisk (for example, 109*) is approximated. 
had a median nitrate concentration equal to $4.5 \mathrm{mg} / \mathrm{L}$. This site is located just downstream from the Snake River Wastewater Treatment Plant and just upstream from Dillon Reservoir. Almost 14 percent (11 of 81) of the nitrate concentrations for this site were greater than the $10 \mathrm{mg} / \mathrm{L}$ domestic watersupply standard. Total nitrogen data only were available for 14 samples collected at 9 sites. The maximum total nitrogen concentration of $14.6 \mathrm{mg} / \mathrm{L}$ was an outlier, as the next highest concentration was $1.24 \mathrm{mg} / \mathrm{L}$.

Orthophosphate concentrations were generally less than $0.032 \mathrm{mg} / \mathrm{L}$ with the exception of one sample that had a concentration of $0.375 \mathrm{mg} / \mathrm{L}$ (table 5). Most (95 percent) total phosphorus concentrations were less than $0.05 \mathrm{mg} / \mathrm{L}$, and about 29 percent of the data were censored values. The median total phosphorus concentration in the Snake River subwatershed was $0.017 \mathrm{mg} / \mathrm{L}$, which was slightly less than the median concentration of $0.020 \mathrm{mg} / \mathrm{L}$ reported by the USEPA for rivers and streams in the southern Rocky Mountains (USEPA Ecoregion II, Level III ecoregion 21; U.S. Environmental Protection Agency, 2000a). Median concentrations at all 15 sites with 6 or more samples also were less than or equal to $0.03 \mathrm{mg} / \mathrm{L}$ (fig. 10). Total phosphorus concentrations in about 4 percent of the individual stream samples (more than one-half from Soda Creek) did not meet the USEPA-recommended limits to control eutrophication in downstream water bodies. Twelve out of 165 samples collected from Soda Creek sites downstream from Snake River Wastewater Treatment Plant had total phosphorus concentrations of $0.05 \mathrm{mg} / \mathrm{L}$ or more, the USEPA-recommended concentration limit for streams that flow directly into reservoirs (U.S Environmental Protection Agency, 1986). The recommended concentration limit of $0.1 \mathrm{mg} / \mathrm{L}$ for streams that do not directly flow into reservoirs was equaled or exceeded in six samples collected at four Snake River sites upstream from Keystone and one sample collected at a Peru Creek site.

Trace-element data were available for 724 samples collected at 88 sites in the Snake River subwatershed (table 3). Concentrations of selected trace elements in some streams, including the upper Snake River, were affected by naturally occurring acidic and metal-enriched drainage (Todd and others, 2005). Trace element concentrations in other streams, including Peru Creek and Cinnamon Gulch, were affected by acidic mine drainage from historical mining in the stream areas. Drainage from the Pennsylvania Mine and Cinnamon Gulch are reported to be the major anthropogenic sources of trace metals to Peru Creek (Bird, 2003; Todd and others, 2005). The acidity of water and elevated trace-element concentrations in mineralized and mined areas result from the oxidation of sulfide-bearing minerals such as pyrite in the local bedrock and the resulting presence of sulfuric acid that dissolves trace elements.

Dissolved and total recoverable arsenic and dissolved chromium and uranium concentrations were low (well below water-quality standards) throughout the Snake River subwatershed (table 5). With a few exceptions, concentrations of total mercury and dissolved silver also were low in the subwatershed. Concentrations of dissolved aluminum, cadmium, copper, iron, lead, manganese, and zinc and total recoverable iron were high (exceeding water-quality standards) in areas affected by naturally occurring acidic and metal-enriched drainage and in mined areas. Aluminum and iron are reactive metals and have higher solubility and increased concentrations in acidic water and lower solubility and decreased concentrations when $\mathrm{pH}$ increases (McKnight and Bencala, 1989, 1990). Dissolved aluminum and iron concentrations decreased downstream with the precipitation of aluminum and iron hydroxides from photoreduction and increases in stream pH (Theobald and others, 1963; McKnight and Bencala, 1989, 1990; Piatak, 2000; Sullivan and Drever, 2001; Kimball and others, 1992; Munk and others, 2002). For example, the median dissolved aluminum concentration (1995-2006) at Snake River above Deer Creek above Montezuma (site 46) in the headwaters was 4,850 micrograms per liter $(\mu \mathrm{g} / \mathrm{L})$; whereas, downstream at Snake River above Keystone (site 48) the median dissolved aluminum concentration $(57 \mu \mathrm{g} / \mathrm{L})$ was about two orders of magnitude lower. Values of $\mathrm{pH}$ measured were between 3.7 and 5.5 at the upstream site (site 46) and between 5.0 and 7.6 at the downstream site (site 48). At the confluence of streams where water from acidic drainages and pristine streams (with higher $\mathrm{pH}$ ) mix, the $\mathrm{pH}$ of the mixed water increases and aluminum and iron precipitate out. Sections of the Snake River and Peru Creek are coated with white and orange deposits from the aluminum and iron precipitates, respectively. In contrast, the solubility of cadmium and zinc does not decrease with increased pH (McKnight and Bencala, 1990; Boyer and others, 1999; Brooks and others, 2001). Concentrations of dissolved cadmium and zinc remained elevated and did not decrease as substantially as did concentrations of dissolved aluminum and iron in downstream segments of the Snake River. For example, the median dissolved zinc concentration was $685 \mu \mathrm{g} / \mathrm{L}$ (1995-2006) in the headwaters at Snake River above Deer Creek above Montezuma (site 46) and $580 \mu \mathrm{g} / \mathrm{L}$ downstream at Snake River above Keystone (site 48). This decrease in the dissolved zinc concentration was likely because of dilution from tributary inflow. Concentrations of dissolved copper and manganese and dissolved and total recoverable iron also remained elevated at sites in downstream segments of the Snake River. Concentrations of iron also were elevated in areas not affected by acidic drainage. Median dissolved iron concentrations at North Fork Snake River near mouth (site 19) and Keystone Gulch near Dillon (site 11) were 27 and $55 \mu \mathrm{g} / \mathrm{L}$, respectively. Iron may be weathering out of intrusive rocks of Tertiary age that are present in the area. Concentrations of dissolved aluminum, cadmium, copper, manganese, and zinc were lower in streams with limited or no mining activity and limited presence of sulfide minerals. Dissolved copper concentrations, for example, were near laboratory reporting levels of 3 or $4 \mu \mathrm{g} / \mathrm{L}$ upstream from the Pennsylvania Mine on Peru Creek and were greater than $56 \mu \mathrm{g} / \mathrm{L}$ at a site downstream from the mine. For most metals, concentrations were higher during low-flow conditions and lower during snowmelt runoff, which is consistent with previous studies (Boyer and others, 1999; Todd and others, 2005). 
A study investigating water-quality trends in Dillon Reservoir using sediment cores found that the Snake River contributed 28 percent of the total inflow to Dillon Reservoir during 1997 and 1998 and contributed most of the copper, manganese, and zinc loads (Greve and others, 2001).

The spatial variations in trace-element concentrations are illustrated in maps of median concentrations of dissolved cadmium, copper, manganese, and zinc for sites with six or more samples (figs. 11-14). Median concentrations of dissolved cadmium, copper, manganese, and zinc were lowest in the North Fork Snake River, Keystone Gulch, and Jones Gulch, streams that are not affected by acidic drainage. Median concentrations were highest in Peru Creek and portions of the Snake River affected by mining and acidic drainage. The effects of dilution are illustrated by dissolved zinc concentrations in the Snake River just upstream and downstream from the confluence with the pristine North Fork Snake River. Median dissolved zinc concentrations were $570 \mu \mathrm{g} / \mathrm{L}$ at Snake River above North Fork Snake River (site 65), less than $10 \mu \mathrm{g} / \mathrm{L}$ at North Fork sites (sites 17-19), and $324 \mu \mathrm{g} / \mathrm{L}$ at Snake River below North Fork Snake River (site 66). Although some trace-element concentrations in the downstream segment of the Snake River (downstream from North Fork Snake River) were diluted compared to concentrations in headwaters areas, concentrations in the downstream segment were elevated compared to streams not affected by acidic drainage, especially for dissolved manganese and zinc. Median dissolved manganese and zinc concentrations at the downstream site Snake River at Keystone Condos (site 50), for example, were 240 and $330 \mu \mathrm{g} / \mathrm{L}$, respectively. As with iron, manganese may be from the weathering of Tertiary intrusive rocks in the area.

Trace-element water-quality standards adopted by the CDPHE for the protection of aquatic life were exceeded in 466 samples collected at 66 sites throughout the Snake River subwatershed (table 6). Exceedances occurred at 75 percent of the sites sampled for trace elements and in 64 percent of samples collected. Concentrations of dissolved cadmium, copper, dissolved and total recoverable iron, lead, manganese, selenium, silver, and zinc, and total mercury were greater than standards. The zinc standard was exceeded at the most sites (54), followed by cadmium (47 sites) and copper (44 sites). Standards for these three trace elements also were exceeded in the most samples (zinc, 70 percent; cadmium, 68 percent; and copper, 41 percent) (table 7). The maximum number of constituents that exceed aquatic-life standards at a site was seven (fig. 15), at Snake River above Deer Creek above Montezuma (site 46). Exceedances occurred most frequently at sites directly affected by acidic drainage, either naturally occurring or from mining, and sites downstream from historical mining, especially sites along the upper Snake River, Peru Creek, Saints John Creek, and the Snake River downstream from the confluence with Peru Creek. The main stem of the Snake River, including most tributaries and wetlands from the source to Dillon Reservoir and Saints John Creek, and the main stem of Peru Creek including all wetlands and tributaries except for Chihuahua Gulch from the source to the Snake River are on the State of Colorado 2008 303(d) list of impaired waters for nonattainment of aquatic-life use standards because of metal contamination and(or) low $\mathrm{pH}$ (Colorado Department of Public Health and Environment, 2008a). Listed trace elements for both segments are dissolved cadmium, copper, lead, and zinc; dissolved manganese also is listed for the Peru Creek segment. Total maximum daily load (TMDL) allocations have been calculated for the listed trace elements (Colorado Department of Public Health and Environment, 2008b). Selenium concentrations were greater than the chronic standard for protection of aquatic life at seven sites-Peru Creek (three sites), Saints John Creek (one site), and upper Snake River (three sites). Laboratory reporting levels for total mercury were greater than the standard for aquatic-life protection. The domestic water-supply standard for dissolved iron was exceeded in 4 percent (20 of 523) of samples collected at five sites, primarily along the upper Snake River (table 5). The manganese domestic water-supply standard was exceeded in 50 percent ( 303 of 605) of samples collected at 28 sites (table 5), primarily along the entire main stem of the Snake River. Domestic water-supply standards have not been adopted for the main stem of Peru Creek, including all tributaries and wetlands except for Chihuahua Gulch, part of a designated segment which includes various clean segments only some of which have actual water-supply uses.

Effects of acidic drainage and metal-enriched water on aquatic biota in the Snake River subwatershed are numerous. Studies have determined the absence of fish and macroinvertebrates in portions of the Snake River and Peru Creek affected by acidic drainage and reduced diversity, populations, and community structure of macroinvertebrates with increased trace-element concentrations (TDS Consulting, Inc., 2004). Acidic stream water and high concentrations of trace elements can be toxic to fish and other aquatic biota. McKnight and Feder (1984), Niyogi (1999), and Belanger (2002) describe how low $\mathrm{pH}$, high trace-element concentrations, and precipitation of metal oxides limit algae, macroinvertebrates, microbes, and fish for many miles downstream from areas with acidic drainage. Todd (2005) reports on differences in benthic macroinvertebrate communities between sites affected by acidic drainage and pristine sites and on limited survival of stocked rainbow trout in metals-contaminated environments. High runoff from intense, short-lived summer thunderstorms increases the mobilization of trace elements and the load of silt in the water, and the survivability of fish can be affected during and after such events. The limiting factor on survival of trout species in much of the Snake River subwatershed is dissolved zinc (Fey and others, 2002; Hansen and others, 2002).

Few suspended-sediment data were available for the Snake River subwatershed (tables 3 and 5). Only 15 samples were collected at three sites: Peru Creek at mouth near Montezuma (site 24, 1 sample), Snake River below mouth of Peru Creek (site 55, 3 samples), and Snake River below Keystone (site 54, 11 samples). The highest concentrations of suspended sediment were measured at Snake River below Keystone in June, typically the month with the greatest snowmelt runoff. Suspended-sediment concentrations also can be elevated during intense, short-lived summer thunderstorms. 


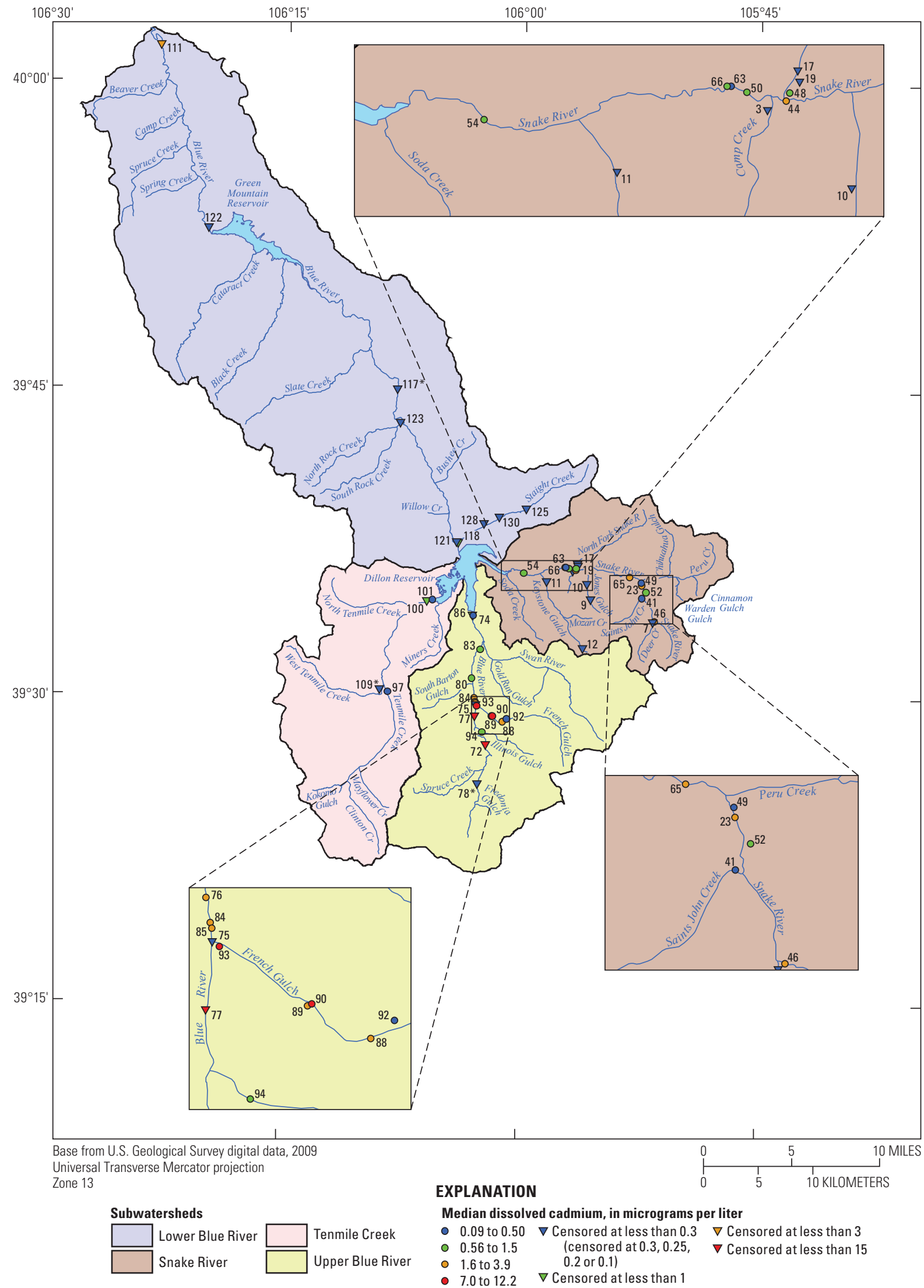

Figure 11. Spatial distribution of median concentrations of dissolved cadmium for selected sites in the Blue River watershed with six or more samples, 1995 through 2006. Number next to symbol is site number, referenced in Appendix 1. The location of sites with an asterisk (for example, 109*) is approximated. 


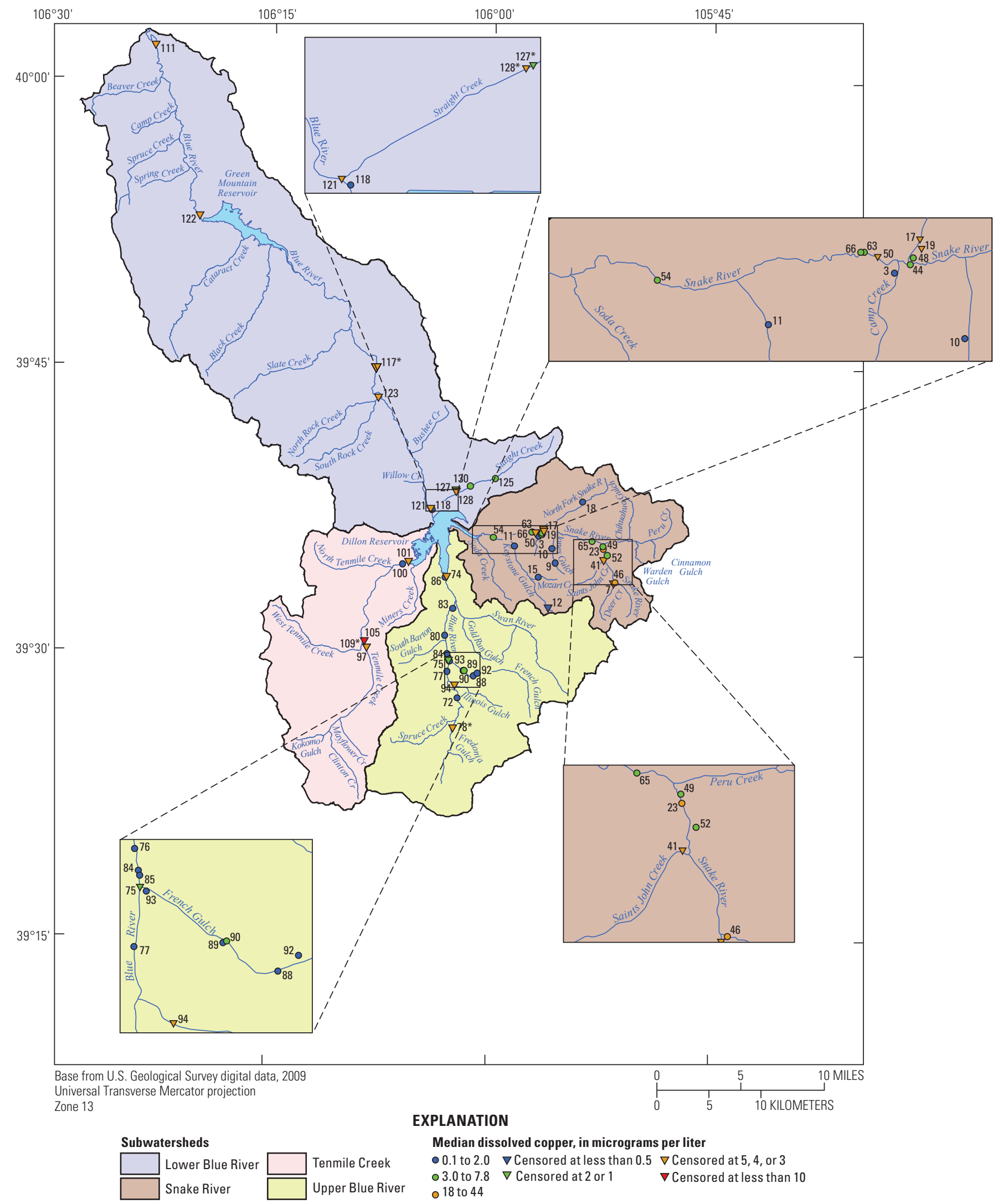

Figure 12. Spatial distribution of median concentrations of dissolved copper for selected sites in the Blue River watershed with six or more samples, 1995 through 2006. Number next to symbol is site number, referenced in Appendix 1. The location of sites with an asterisk (for example, 109*) is approximated. 


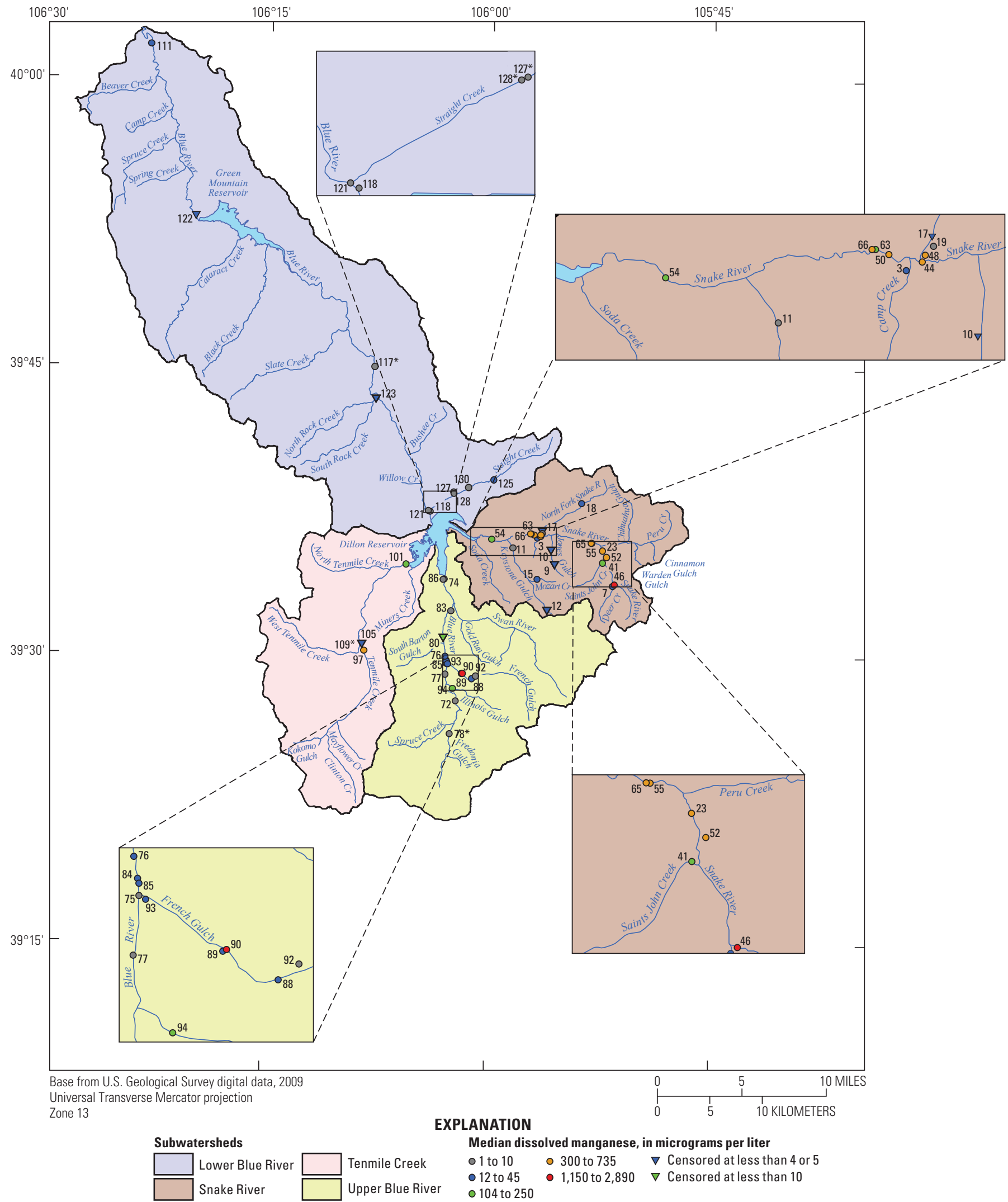

Figure 13. Spatial distribution of median concentrations of dissolved manganese for selected sites in the Blue River watershed with six or more samples, 1995 through 2006. Number next to symbol is site number, referenced in Appendix 1. The location of sites with an asterisk (for example, 109*) is approximated. 


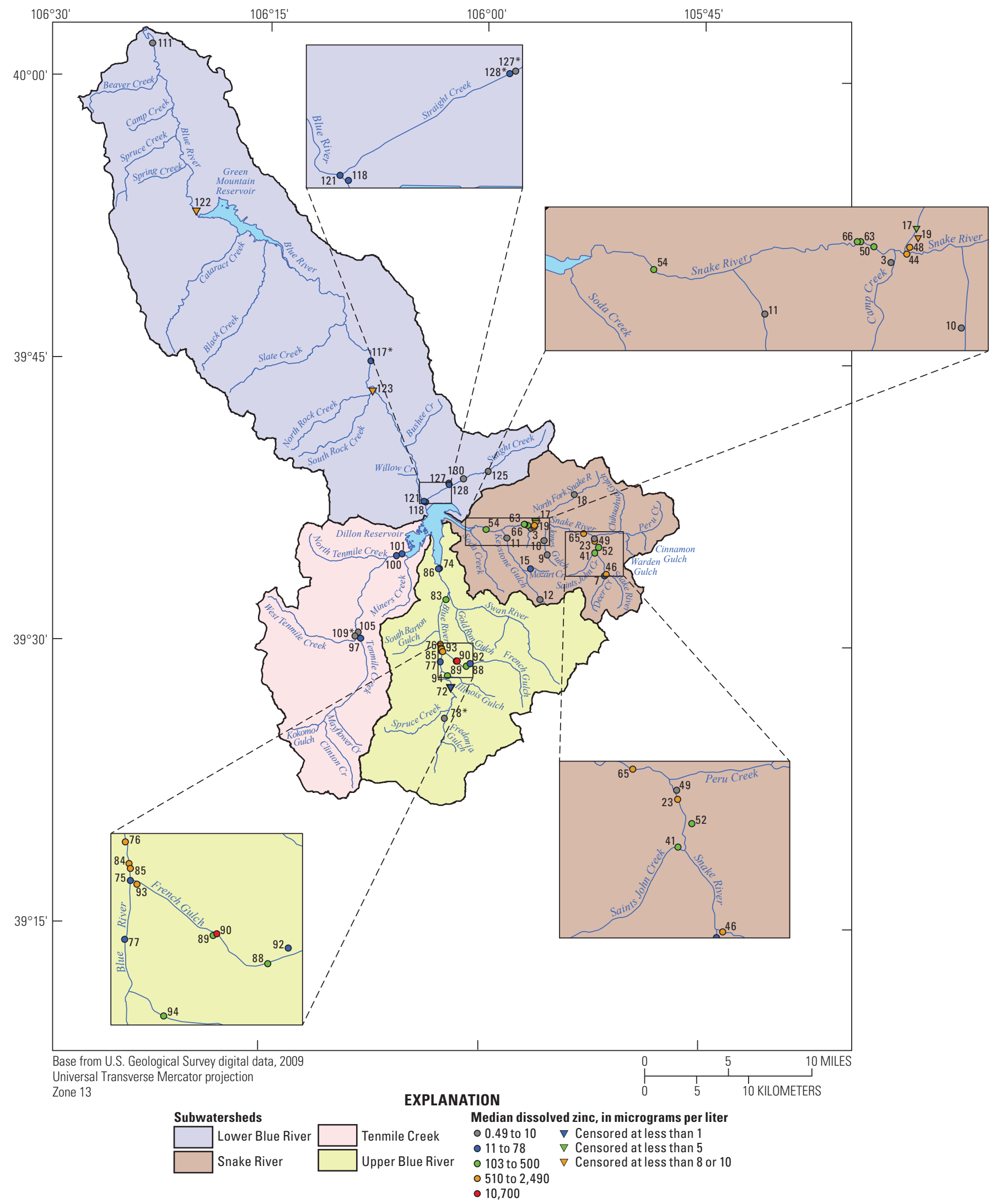

Figure 14. Spatial distribution of median concentrations of dissolved zinc for selected sites in the Blue River watershed with six or more samples, 1995 through 2006. Number next to symbol is site number, referenced in Appendix 1. The location of sites with an asterisk (for example, 109*) is approximated. 
Table 6. Exceedances of Colorado Department of Public Health and Environment in-stream water-quality standards for trace elements in the Snake River, upper Blue River, and Tenmile Creek subwatersheds and the lower Blue River watershed, Blue River watershed, Colorado, October 1995 through July 2006.

$[\mu \mathrm{g} / \mathrm{L}$, micrograms per liter; CDPHE, Colorado Department of Public Health and Environment; --, data not censored; DWS, domestic water supply. Range of concentration and number of samples with concentration greater than standard do not include samples with concentrations that were censored. Water-quality standards are from Colorado Department of Public Health and Environment (2008c, 2008d); standards are for protection of aquatic life unless otherwise stated. Site names without a site number (shown with an $\mathbf{m}$ ) do not have latitude and longitude data available and are not shown in figure 15 or listed in Appendix 1]

\begin{tabular}{|c|c|c|c|c|c|c|}
\hline $\begin{array}{l}\text { Site number } \\
\text { in this report } \\
\text { (fig. 15; } \\
\text { Appendix 1) }\end{array}$ & $\begin{array}{c}\text { Site name } \\
\text { (fig. 15; Appendix 1) }\end{array}$ & $\begin{array}{l}\text { Number of } \\
\text { samples/ } \\
\text { number of } \\
\text { censored } \\
\text { values }\end{array}$ & $\begin{array}{l}\text { Censoring } \\
\text { limit }\end{array}$ & $\begin{array}{c}\text { Range of } \\
\text { concentration } \\
(\mu \mathrm{g} / \mathrm{L})\end{array}$ & $\begin{array}{c}\text { CDPHE } \\
\text { in-stream water- } \\
\text { quality standard } \\
\text { ( } \mu \mathrm{g} / \mathrm{L} \text { ) } \\
\text { (acute/chronic) }\end{array}$ & $\begin{array}{l}\text { Number of samples } \\
\text { with concentration } \\
\text { greater than } \\
\text { water-quality standard } \\
\text { (acute/chronic) }\end{array}$ \\
\hline \multicolumn{7}{|c|}{ Snake River subwatershed } \\
\hline \multicolumn{7}{|c|}{ Cadmium, dissolved } \\
\hline 4 & Cinnamon Gulch & $1 / 0$ & -- & 6 & $0.70 / 0.20$ & $1 / 1$ \\
\hline 7 & Deer Creek above Montezuma at mouth & $21 / 20$ & 0.3 & 0.4 & $0.76 / 0.21$ & $0 / 1$ \\
\hline 12 & Keystone Gulch stream grab 1 & $6 / 5$ & $0.1,1$ & 0.8 & $0.82 / 0.22$ & $0 / 1$ \\
\hline 13 & Keystone Gulch stream grab 2 & $3 / 2$ & 0.1 & 0.4 & $0.88 / 0.24$ & $0 / 1$ \\
\hline 16 & National Treasury surface water & $4 / 0$ & -- & $0.2-2.6$ & $1.3 / 0.34$ & $2 / 2$ \\
\hline 17 & $\begin{array}{l}\text { North Fork Snake River at Montezuma Road above River Run } 03 \text { mi above } \\
\text { Snake River }\end{array}$ & $11 / 10$ & 0.1 & 1.1 & $0.75 / 0.21$ & $1 / 1$ \\
\hline 20 & Peru Creek 01 mile upstream of confluence with Snake River & $2 / 0$ & -- & $2.0-3.9$ & $0.96 / 0.26$ & $2 / 2$ \\
\hline 23 & Peru Creek at mouth & $26 / 0$ & -- & $0.46-5.6$ & $1.0 / 0.27$ & $23 / 26$ \\
\hline 24 & Peru Creek at mouth near Montezuma, $\mathrm{CO}$ & $4 / 0$ & -- & $1.51-4.5$ & $1.1 / 0.29$ & $4 / 4$ \\
\hline 25 & Peru Creek at Peru Creek below FR 214 & $3 / 0$ & -- & $5.28-5.81$ & $1.1 / 0.29$ & $3 / 3$ \\
\hline 226 & Peru Creek below Pennsylvania Mine near Keystone & $1 / 0$ & -- & 7.8 & $0.98 / 0.26$ & $1 / 1$ \\
\hline 28 & Peru Creek downstream of Pennsylvania Mine & $3 / 0$ & -- & $2.88-8.0$ & $1.2 / 0.31$ & $3 / 3$ \\
\hline 29 & Peru Creek upstream of Pennsylvania Mine & $2 / 1$ & 0.3 & 0.79 & $1.01 / 0.27$ & $0 / 1$ \\
\hline 32 & Peru Creek 139 meters downstream of injection ${ }^{1}$ & $6 / 0$ & -- & $6-14$ & $0.70 / 0.20$ & $6 / 6$ \\
\hline 33 & Peru Creek 251 meters downstream of injection ${ }^{1}$ & $7 / 0$ & -- & $6-16$ & $0.70 / 0.20$ & $7 / 7$ \\
\hline 34 & Peru Creek 485 meters downstream of injection ${ }^{1}$ & $6 / 0$ & -- & $14-20$ & $0.98 / 0.26$ & $6 / 6$ \\
\hline 35 & Peru Creek 583 meters downstream of injection ${ }^{1}$ & $7 / 0$ & -- & $10-18$ & $0.98 / 0.26$ & $7 / 7$ \\
\hline 36 & Peru Creek 824 meters downstream of injection ${ }^{1}$ & $5 / 0$ & -- & $14-18$ & $0.98 / 0.26$ & $5 / 5$ \\
\hline 37 & Peru Creek 908 meters downstream of injection ${ }^{1}$ & $5 / 0$ & -- & $13-16$ & $0.98 / 0.26$ & $5 / 5$ \\
\hline 38 & Peru Creek tributary 60 meters downstream of injection ${ }^{1}$ & $1 / 0$ & -- & 619 & $0.70 / 0.20$ & $1 / 1$ \\
\hline 39 & Peru Creek tributary 530 meters downstream of injection ${ }^{1}$ & $1 / 0$ & -- & 6 & $0.98 / 0.26$ & $1 / 1$ \\
\hline 40 & Peruvian surface water & $2 / 0$ & -- & $0.2-0.5$ & $1.4 / 0.37$ & $0 / 1$ \\
\hline 41 & Saints John Creek at Montezuma & $22 / 4$ & 0.3 & $0.3-3.5$ & $1.5 / 0.39$ & $2 / 15$ \\
\hline 43 & Shoe Basin surface water & $3 / 0$ & -- & $0.2-0.5$ & $1.4 / 0.35$ & $0 / 2$ \\
\hline 44 & Snake River 300 feet above North Fork & $25 / 1$ & 5 & $0.8-2.5$ & $0.95 / 0.26$ & $20 / 24$ \\
\hline 45 & Snake River above confluence with Deer Creek & $2 / 0$ & -- & $1.39-3.2$ & $1.0 / 0.27$ & $2 / 2$ \\
\hline 46 & Snake River above Deer Creek above Montezuma & $20 / 0$ & -- & $0.8-4.2$ & $0.94 / 0.25$ & $19 / 20$ \\
\hline 48 & Snake River above Keystone & $32 / 5$ & $0.25,0.6$ & $0.9-3.0$ & $1.0 / 0.27$ & $24 / 27$ \\
\hline 49 & Snake River above Peru Creek & $8 / 0$ & -- & $0.177-2.37$ & $1.1 / 0.29$ & $3 / 7$ \\
\hline 50 & Snake River at Keystone condos 075 miles below North Fork, below bridge & $25 / 2$ & 5 & $0.5-1.7$ & $0.89 / 0.24$ & $16 / 23$ \\
\hline 51 & Snake River at Keystone Science Center bridge & $5 / 0$ & -- & $0.48-0.87$ & $0.97 / 0.26$ & $0 / 5$ \\
\hline 52 & Snake River at Montezuma & $30 / 0$ & -- & $0.4-2.0$ & $1.0 / 0.27$ & $24 / 30$ \\
\hline 53 & Snake R above confluence with Keystone Gulch & $5 / 0$ & -- & $0.5-0.85$ & $0.94 / 0.25$ & $0 / 5$ \\
\hline 54 & Snake River below Keystone, CO & $16 / 7$ & $0.25,1$ & $0.55-1.18$ & $0.84 / 0.23$ & $4 / 9$ \\
\hline
\end{tabular}


Table 6. Exceedances of Colorado Department of Public Health and Environment in-stream water-quality standards for trace elements in the Snake River, upper Blue River, and Tenmile Creek subwatersheds and the lower Blue River watershed, Blue River watershed, Colorado, October 1995 through July 2006.—Continued

$[\mu \mathrm{g} / \mathrm{L}$, micrograms per liter; CDPHE, Colorado Department of Public Health and Environment; --, data not censored; DWS, domestic water supply. Range of concentration and number of samples with concentration greater than standard do not include samples with concentrations that were censored. Water-quality standards are from Colorado Department of Public Health and Environment (2008c, 2008d); standards are for protection of aquatic life unless otherwise stated. Site names without a site number (shown with an $\mathbf{\square}$ ) do not have latitude and longitude data available and are not shown in figure 15 or listed in Appendix 1]

\begin{tabular}{|c|c|c|c|c|c|c|}
\hline $\begin{array}{l}\text { Site number } \\
\text { in this report } \\
\text { (fig. 15; } \\
\text { Appendix 1) }\end{array}$ & $\begin{array}{c}\text { Site name } \\
\text { (fig. 15; Appendix 1) }\end{array}$ & $\begin{array}{c}\text { Number of } \\
\text { samples/ } \\
\text { number of } \\
\text { censored } \\
\text { values } \\
\end{array}$ & $\begin{array}{l}\text { Censoring } \\
\text { limit }\end{array}$ & $\begin{array}{c}\text { Range of } \\
\text { concentration } \\
(\mu \mathrm{g} / \mathrm{L})\end{array}$ & $\begin{array}{c}\text { CDPHE } \\
\text { in-stream water- } \\
\text { quality standard } \\
\text { ( } \mu \mathrm{g} / \mathrm{L} \text { ) } \\
\text { (acute/chronic) } \\
\end{array}$ & $\begin{array}{c}\text { Number of samples } \\
\text { with concentration } \\
\text { greater than } \\
\text { water-quality standard } \\
\text { (acute/chronic) } \\
\end{array}$ \\
\hline \multicolumn{7}{|c|}{ Cadmium, dissolved-Continued } \\
\hline 55 & Snake River below mouth of Peru Creek & $5 / 0$ & -- & $1.2-2.9$ & $1.2 / 0.31$ & $5 / 5$ \\
\hline 56 & Snake River downstream of confluence with Peru Creek & $2 / 1$ & 1.6 & 3.3 & $1.2 / 0.31$ & $1 / 1$ \\
\hline 57 & Snake River downstream sample - just before Dillon Reservoir & $1 / 0$ & -- & 1.3 & $0.84 / 0.23$ & $1 / 1$ \\
\hline - & Snake River inlet at Dillon Reservoir & $10 / 6$ & $0.5,1$ & $0.5-1.0$ & $1.0 / 0.27$ & $0 / 4$ \\
\hline 58 & Snake River just before confluence with Peru Creek, background & $2 / 1$ & 0.75 & 1.8 & $1.1 / 0.29$ & $1 / 1$ \\
\hline 59 & Snake River just below confluence with Thurman Gulch & $1 / 0$ & -- & 3.1 & $1.2 / 0.31$ & $1 / 1$ \\
\hline 60 & Snake River near Montezuma, CO & $5 / 3$ & 0.25 & $1.0-1.2$ & $0.81 / 0.22$ & $2 / 2$ \\
\hline 63 & Snake River stream grab 1 (snowmaking intake) & $18 / 6$ & $0.2,1$ & $0.2-1.9$ & $0.96 / 0.26$ & $4 / 10$ \\
\hline - & Snake River stream grab 2 (snowmaking intake) & $1 / 0$ & -- & 2 & $0.95 / 0.26$ & $1 / 1$ \\
\hline 64 & Snake River upstream of Peru Creek confluence & $3 / 0$ & -- & $0.69-1.2$ & $1.2 / 0.31$ & $1 / 3$ \\
\hline 65 & Snake River above North Fork Snake River & $32 / 0$ & -- & $1.99-2.98$ & $0.96 / 0.26$ & $32 / 32$ \\
\hline 66 & Snake River below North Fork Snake River & $32 / 0$ & -- & $0.87-1.65$ & $0.87 / 0.24$ & $32 / 32$ \\
\hline 70 & South Paymaster surface water & $6 / 4$ & 0.1 & $0.3-1.0$ & $0.3 / 0.09$ & $1 / 2$ \\
\hline \multicolumn{7}{|c|}{ Copper, dissolved } \\
\hline 4 & Cinnamon Gulch & $1 / 0$ & -- & 207 & $5.1 / 3.7$ & $1 / 1$ \\
\hline 9 & Jones Gulch stream grab 1 & $12 / 8$ & $0.5,1$ & $0.6-6$ & $6.2 / 4.4$ & $0 / 1$ \\
\hline 10 & Jones Gulch stream grab 2 & $14 / 7$ & $0.5,1$ & $0.5-8.4$ & $6.4 / 4.6$ & $0 / 1$ \\
\hline 16 & National Treasury surface water & $4 / 2$ & 1 & 13 & $10.3 / 7.0$ & $2 / 2$ \\
\hline 20 & Peru Creek 01 mile upstream of confluence with Snake River & $2 / 0$ & -- & $5.6-70$ & $7.3 / 5.1$ & $1 / 2$ \\
\hline 23 & Peru Creek at mouth & $26 / 2$ & 4 & $5-110$ & $7.7 / 5.4$ & $21 / 22$ \\
\hline 24 & Peru Creek at mouth near Montezuma, $\mathrm{CO}$ & $4 / 0$ & -- & $8.09-84.2$ & $8.3 / 5.8$ & $3 / 4$ \\
\hline 25 & Peru Creek at Peru Creek below FR 214 & $3 / 0$ & -- & $62.2-92.0$ & $8.3 / 5.8$ & $3 / 3$ \\
\hline${ }^{2} 26$ & Peru Creek below Pennsylvania Mine near Keystone & $1 / 0$ & -- & 290 & $7.4 / 5.2$ & $1 / 1$ \\
\hline 227 & Peru Creek below Shoe Basin input (high flow sample site) & $1 / 0$ & -- & 5 & $5.9 / 4.2$ & $0 / 1$ \\
\hline 28 & Peru Creek downstream of Pennsylvania Mine & $3 / 0$ & -- & $56.7-262$ & $9.1 / 6.3$ & $3 / 3$ \\
\hline 230 & Peru Creek 0 meters downstream of injection ${ }^{1}$ & $1 / 0$ & -- & 22 & $5.1 / 3.7$ & $1 / 1$ \\
\hline 31 & Peru Creek 51 meters downstream of injection ${ }^{1}$ & $7 / 0$ & -- & 4-22 & $5.1 / 3.7$ & $4 / 7$ \\
\hline 32 & Peru Creek 139 meters downstream of injection ${ }^{1}$ & $6 / 0$ & -- & $147-153$ & $5.1 / 3.7$ & $6 / 6$ \\
\hline 33 & Peru Creek 251 meters downstream of injection ${ }^{1}$ & $7 / 0$ & -- & $185-191$ & $5.1 / 3.7$ & $7 / 7$ \\
\hline 34 & Peru Creek 485 meters downstream of injection ${ }^{1}$ & $6 / 0$ & -- & $81-230$ & $7.4 / 5.2$ & $6 / 6$ \\
\hline 35 & Peru Creek 583 meters downstream of injection ${ }^{1}$ & $7 / 0$ & -- & $75-231$ & $7.4 / 5.2$ & $7 / 7$ \\
\hline 36 & Peru Creek 824 meters downstream of injection ${ }^{1}$ & $5 / 0$ & -- & $224-229$ & $7.4 / 5.2$ & $5 / 5$ \\
\hline
\end{tabular}


Table 6. Exceedances of Colorado Department of Public Health and Environment in-stream water-quality standards for trace elements in the Snake River, upper Blue River, and Tenmile Creek subwatersheds and the lower Blue River watershed, Blue River watershed, Colorado, October 1995 through July 2006.—Continued

$[\mu \mathrm{g} / \mathrm{L}$, micrograms per liter; CDPHE, Colorado Department of Public Health and Environment; --, data not censored; DWS, domestic water supply. Range of concentration and number of samples with concentration greater than standard do not include samples with concentrations that were censored. Water-quality standards are from Colorado Department of Public Health and Environment (2008c, 2008d); standards are for protection of aquatic life unless otherwise stated. Site names without a site number (shown with an $\mathbf{m}$ ) do not have latitude and longitude data available and are not shown in figure 15 or listed in Appendix 1]

\begin{tabular}{|c|c|c|c|c|c|c|}
\hline $\begin{array}{l}\text { Site number } \\
\text { in this report } \\
\text { (fig. 15; } \\
\text { Appendix 1) }\end{array}$ & $\begin{array}{c}\text { Site name } \\
\text { (fig. 15; Appendix 1) }\end{array}$ & $\begin{array}{c}\text { Number of } \\
\text { samples/ } \\
\text { number of } \\
\text { censored } \\
\text { values } \\
\end{array}$ & $\begin{array}{l}\text { Censoring } \\
\text { limit }\end{array}$ & $\begin{array}{c}\text { Range of } \\
\text { concentration } \\
(\mu \mathrm{g} / \mathrm{L})\end{array}$ & $\begin{array}{c}\text { CDPHE } \\
\text { in-stream water- } \\
\text { quality standard } \\
\text { ( } \mu \mathrm{g} / \mathrm{L} \text { ) } \\
\text { (acute/chronic) }\end{array}$ & $\begin{array}{l}\text { Number of samples } \\
\text { with concentration } \\
\text { greater than } \\
\text { water-quality standard } \\
\text { (acute/chronic) }\end{array}$ \\
\hline \multicolumn{7}{|c|}{ Copper, dissolved-Continued } \\
\hline 37 & Peru Creek 908 meters downstream of injection ${ }^{1}$ & $5 / 0$ & -- & $216-229$ & $7.4 / 5.2$ & $5 / 5$ \\
\hline 38 & Peru Creek tributary 60 meters downstream of injection ${ }^{1}$ & $1 / 0$ & -- & 11,060 & $5.1 / 3.7$ & $1 / 1$ \\
\hline 39 & Peru Creek tributary 530 meters downstream of injection ${ }^{1}$ & $1 / 0$ & -- & 205 & $7.4 / 5.2$ & $1 / 1$ \\
\hline 43 & Shoe Basin surface water & $3 / 1$ & 1 & $2-8$ & $10.7 / 7.2$ & $0 / 1$ \\
\hline 44 & Snake River 300 feet above North Fork & $25 / 14$ & 5 & $5-8$ & $7.2 / 5.1$ & $2 / 6$ \\
\hline 45 & Snake River above confluence with Deer Creek & $2 / 0$ & -- & $11.8-17.1$ & $7.6 / 5.3$ & $2 / 2$ \\
\hline 46 & Snake River above Deer Creek above Montezuma & $20 / 0$ & -- & $9-21$ & $7.1 / 5.0$ & $20 / 20$ \\
\hline 48 & Snake River above Keystone & $32 / 6$ & 4,5 & $4-18$ & $7.6 / 5.3$ & $12 / 20$ \\
\hline 49 & Snake River above Peru Creek & $8 / 0$ & - & $1.05-11.8$ & $8.4 / 5.9$ & $2 / 4$ \\
\hline 50 & Snake River at Keystone condos 075 miles below North Fork, below bridge & $25 / 22$ & 5 & $5-7$ & $6.6 / 4.7$ & $2 / 3$ \\
\hline 51 & Snake River at Keystone Science Center bridge & $4 / 0$ & -- & $2.1-10.5$ & $7.3 / 5.2$ & $1 / 1$ \\
\hline 52 & Snake River at Montezuma & $30 / 6$ & 4 & $3-9$ & $7.6 / 5.3$ & $8 / 21$ \\
\hline 53 & Snake R above confluence with Keystone Gulch & $5 / 0$ & -- & $2.8-16.6$ & $7.1 / 5.0$ & $1 / 2$ \\
\hline 54 & Snake River below Keystone, $\mathrm{CO}$ & $16 / 2$ & 4 & $2.7-6.3$ & $6.2 / 4.5$ & $1 / 8$ \\
\hline 55 & Snake River below mouth of Peru Creek & $5 / 0$ & -- & $4.66-29.5$ & $9.0 / 6.2$ & $3 / 4$ \\
\hline 56 & Snake River downstream of confluence with Peru Creek & $2 / 1$ & 4.1 & 43.9 & $9.0 / 6.2$ & $1 / 1$ \\
\hline 57 & Snake River downstream sample - just before Dillon Reservoir & $1 / 0$ & -- & 5.4 & $6.2 / 4.5$ & $0 / 1$ \\
\hline 59 & Snake River just below confluence with Thurman Gulch & $1 / 0$ & -- & 32.4 & $9.0 / 6.2$ & $1 / 1$ \\
\hline 60 & Snake River near Montezuma, CO & $5 / 3$ & 4 & 4-9 & $6.0 / 4.3$ & $1 / 1$ \\
\hline 63 & Snake River stream grab 1 (snowmaking intake) & $16 / 4$ & $1,5,10$ & $2-10$ & $7.3 / 5.1$ & $2 / 3$ \\
\hline - & Snake River stream grab 2 (snowmaking intake) & $4 / 0$ & - & $3-23$ & $7.1 / 5.0$ & $3 / 3$ \\
\hline - & Snake River stream grab 3 (below snowmaking intake) & $4 / 0$ & -- & $3-10$ & $7.1 / 5.0$ & $2 / 2$ \\
\hline 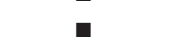 & Snake River stream grab 4 (below snowmaking intake) & $4 / 0$ & -- & $4-10$ & $7.8 / 5.5$ & $1 / 2$ \\
\hline 65 & Snake River above North Fork Snake River & $32 / 0$ & -- & $4.44-11.7$ & $7.2 / 5.1$ & $18 / 31$ \\
\hline 66 & Snake River below North Fork Snake River & $32 / 0$ & -- & $2.36-6.23$ & $6.5 / 4.6$ & $0 / 6$ \\
\hline 69 & Soda Creek downstream Snake River wasterwater treatment plant & $5 / 4$ & 3,4 & 17 & $14.0 / 9.3$ & $1 / 1$ \\
\hline \multicolumn{7}{|c|}{ 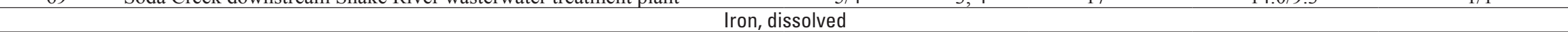 } \\
\hline 3 & Camp Creek stream grab 2 & $19 / 0$ & -- & $50-330$ & 300 DWS (chronic) & 1 \\
\hline 45 & Snake River above confluence with Deer Creek & $2 / 0$ & -- & $608-830$ & 300 DWS (chronic) & 2 \\
\hline 46 & Snake River above Deer Creek above Montezuma & $14 / 0$ & -- & $430-1,500$ & 300 DWS (chronic) & 14 \\
\hline 49 & Snake River above Peru Creek & $8 / 0$ & -- & $40-682$ & 300 DWS (chronic) & 1 \\
\hline 52 & Snake River at Montezuma & $21 / 1$ & 10 & $49-570$ & 300 DWS (chronic) & 2 \\
\hline
\end{tabular}


Table 6. Exceedances of Colorado Department of Public Health and Environment in-stream water-quality standards for trace elements in the Snake River, upper Blue River, and Tenmile Creek subwatersheds and the lower Blue River watershed, Blue River watershed, Colorado, October 1995 through July 2006.—Continued

$[\mu \mathrm{g} / \mathrm{L}$, micrograms per liter; CDPHE, Colorado Department of Public Health and Environment; --, data not censored; DWS, domestic water supply. Range of concentration and number of samples with concentration greater than standard do not include samples with concentrations that were censored. Water-quality standards are from Colorado Department of Public Health and Environment (2008c, 2008d); standards are for protection of aquatic life unless otherwise stated. Site names without a site number (shown with an $\mathbf{m}$ ) do not have latitude and longitude data available and are not shown in figure 15 or listed in Appendix 1]

\begin{tabular}{|c|c|c|c|c|c|c|}
\hline $\begin{array}{l}\text { Site number } \\
\text { in this report } \\
\text { (fig. 15; } \\
\text { Appendix 1) }\end{array}$ & $\begin{array}{c}\text { Site name } \\
\text { (fig. 15; Appendix 1) }\end{array}$ & $\begin{array}{c}\text { Number of } \\
\text { samples/ } \\
\text { number of } \\
\text { censored } \\
\text { values } \\
\end{array}$ & $\begin{array}{l}\text { Censoring } \\
\text { limit }\end{array}$ & $\begin{array}{c}\text { Range of } \\
\text { concentration } \\
(\mu \mathrm{g} / \mathrm{L})\end{array}$ & $\begin{array}{c}\text { CDPHE } \\
\text { in-stream water- } \\
\text { quality standard } \\
\text { ( } \mu \mathrm{g} / \mathrm{L} \text { ) } \\
\text { (acute/chronic) }\end{array}$ & $\begin{array}{c}\text { Number of samples } \\
\text { with concentration } \\
\text { greater than } \\
\text { water-quality standard } \\
\text { (acute/chronic) } \\
\end{array}$ \\
\hline \multicolumn{7}{|c|}{ Iron, total recoverable } \\
\hline 1 & Camp Creek autosampler & $26 / 0$ & -- & $140-5,970$ & 1,000 (chronic) & 8 \\
\hline 3 & Camp Creek stream grab 2 & $15 / 0$ & -- & $110-6,950$ & 1,000 (chronic) & 1 \\
\hline 5 & Cinnamon Gulch at toe of waste rock pile & $2 / 0$ & -- & $12,400-18,600$ & 1,000 (chronic) & 2 \\
\hline 6 & Cinnamon Gulch below mines and before wetlands & $2 / 0$ & -- & $481-1,780$ & 1,000 (chronic) & 1 \\
\hline 12 & Keystone Gulch stream grab 1 & $11 / 1$ & 50 & $20-1,720$ & 1,000 (chronic) & 1 \\
\hline 14 & Mozart Creek autosampler & $25 / 0$ & -- & $200-8,720$ & 1,000 (chronic) & 5 \\
\hline 22 & Peru Creek at gravesite below the confluence with Cinnamon Gulch & $1 / 0$ & -- & 1,050 & 1,000 (chronic) & 1 \\
\hline${ }^{2} 26$ & Peru Creek below Pennsylvania Mine near Keystone & $1 / 0$ & -- & 1,700 & 1,000 (chronic) & 1 \\
\hline 45 & Snake River above confluence with Deer Creek & $2 / 0$ & -- & $874-1,020$ & 1,000 (chronic) & 1 \\
\hline 46 & Snake River above Deer Creek above Montezuma & $20 / 0$ & -- & $390-2,200$ & 1,000 (chronic) & 4 \\
\hline 48 & Snake River above Keystone & $32 / 0$ & -- & $19-1,300$ & 1,000 (chronic) & 1 \\
\hline 52 & Snake River at Montezuma & $30 / 0$ & -- & $140-1,500$ & 1,000 (chronic) & 2 \\
\hline 54 & Snake River below Keystone, $\mathrm{CO}$ & $15 / 1$ & 10 & $95-1,740$ & 1,000 (chronic) & 1 \\
\hline 63 & Snake River stream grab 1 (snowmaking intake) & $17 / 2$ & 10 & $40-6,670$ & 1,000 (chronic) & 2 \\
\hline \multicolumn{7}{|c|}{ 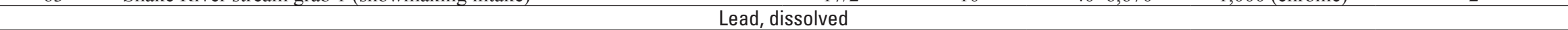 } \\
\hline 4 & Cinnamon Gulch & $1 / 0$ & -- & 47.8 & $20.9 / 0.81$ & $1 / 1$ \\
\hline 17 & $\begin{array}{l}\text { North Fork Snake River at Montezuma Road above River Run } 03 \text { mi above } \\
\text { Snake River }\end{array}$ & $11 / 10$ & 1 & 1 & $22.9 / 0.89$ & $0 / 1$ \\
\hline 16 & National Treasury surface water & $4 / 1$ & 1 & $2-3$ & $47.2 / 1.8$ & $0 / 3$ \\
\hline 20 & Peru Creek 01 mile upstream of confluence with Snake River & $2 / 1$ & 1.6 & 5.9 & $31.5 / 1.2$ & $0 / 1$ \\
\hline 23 & Peru Creek at mouth & $26 / 8$ & 1 & $1-8$ & $33.6 / 1.3$ & $0 / 17$ \\
\hline 24 & Peru Creek at mouth near Montezuma, $\mathrm{CO}$ & $4 / 0$ & -- & $0.38-5.2$ & $37.1 / 1.4$ & $0 / 2$ \\
\hline 25 & Peru Creek at Peru Creek below FR 214 & $2 / 0$ & -- & $4.5-7.3$ & $37.1 / 1.4$ & $0 / 2$ \\
\hline 226 & Peru Creek below Pennsylvania Mine near Keystone & $1 / 0$ & -- & 3 & $32.2 / 1.2$ & $0 / 1$ \\
\hline 227 & Peru Creek below Shoe Basin input (high flow sample site) & $1 / 0$ & -- & 4 & $24.5 / 0.95$ & $0 / 1$ \\
\hline 28 & Peru Creek downstream of Pennsylvania Mine & $3 / 1$ & 2 & $2.5-2.68$ & $41.1 / 1.6$ & $0 / 2$ \\
\hline 29 & Peru Creek upstream of Pennsylvania Mine & $2 / 1$ & 2 & 1.59 & $34.0 / 1.3$ & $0 / 1$ \\
\hline 230 & Peru Creek 0 meters downstream of injection ${ }^{1}$ & $1 / 0$ & -- & 1.41 & $20.9 / 0.81$ & $0 / 1$ \\
\hline 31 & Peru Creek 51 meters downstream of injection ${ }^{1}$ & $3 / 0$ & -- & $0.73-1.38$ & $20.9 / 0.81$ & $0 / 2$ \\
\hline 32 & Peru Creek 139 meters downstream of injection ${ }^{1}$ & $2 / 0$ & -- & $1.89-2.48$ & $20.9 / 0.81$ & $0 / 2$ \\
\hline 33 & Peru Creek 251 meters downstream of injection ${ }^{1}$ & $3 / 0$ & -- & $1.76-1.85$ & $20.9 / 0.81$ & $0 / 3$ \\
\hline 34 & Peru Creek 485 meters downstream of injection ${ }^{1}$ & $2 / 0$ & -- & $2.71-3$ & $32.1 / 1.2$ & $0 / 2$ \\
\hline 35 & Peru Creek 583 meters downstream of injection ${ }^{1}$ & $2 / 0$ & -- & $2.9-3.13$ & $32.1 / 1.2$ & $0 / 2$ \\
\hline 36 & Peru Creek 824 meters downstream of injection ${ }^{1}$ & $2 / 0$ & -- & $3.28-3.58$ & $32.1 / 1.2$ & $0 / 2$ \\
\hline
\end{tabular}


Table 6. Exceedances of Colorado Department of Public Health and Environment in-stream water-quality standards for trace elements in the Snake River, upper Blue River, and Tenmile Creek subwatersheds and the lower Blue River watershed, Blue River watershed, Colorado, October 1995 through July 2006.—Continued

$[\mu \mathrm{g} / \mathrm{L}$, micrograms per liter; CDPHE, Colorado Department of Public Health and Environment; --, data not censored; DWS, domestic water supply. Range of concentration and number of samples with concentration greater than standard do not include samples with concentrations that were censored. Water-quality standards are from Colorado Department of Public Health and Environment (2008c, 2008d); standards are for protection of aquatic life unless otherwise stated. Site names without a site number (shown with an $\mathbf{\square}$ ) do not have latitude and longitude data available and are not shown in figure 15 or listed in Appendix 1]

\begin{tabular}{|c|c|c|c|c|c|c|}
\hline $\begin{array}{l}\text { Site number } \\
\text { in this report } \\
\text { (fig. 15; } \\
\text { Appendix 1) }\end{array}$ & $\begin{array}{c}\text { Site name } \\
\text { (fig. 15; Appendix 1) }\end{array}$ & $\begin{array}{l}\text { Number of } \\
\text { samples/ } \\
\text { number of } \\
\text { censored } \\
\text { values }\end{array}$ & $\begin{array}{l}\text { Censoring } \\
\text { limit }\end{array}$ & $\begin{array}{c}\text { Range of } \\
\text { concentration } \\
(\mu \mathrm{g} / \mathrm{L})\end{array}$ & $\begin{array}{c}\text { CDPHE } \\
\text { in-stream water- } \\
\text { quality standard } \\
\text { ( } \mu \mathrm{g} / \mathrm{L} \text { ) } \\
\text { (acute/chronic) }\end{array}$ & $\begin{array}{l}\text { Number of samples } \\
\text { with concentration } \\
\text { greater than } \\
\text { water-quality standard } \\
\text { (acute/chronic) }\end{array}$ \\
\hline \multicolumn{7}{|c|}{ Lead, dissolved-Continued } \\
\hline 37 & Peru Creek 908 meters downstream of injection ${ }^{1}$ & $2 / 0$ & -- & $8.85-9.08$ & $32.1 / 1.2$ & $0 / 2$ \\
\hline 38 & Peru Creek tributary 60 meters downstream of injection ${ }^{1}$ & $1 / 0$ & -- & 27.5 & $20.9 / 0.81$ & $1 / 1$ \\
\hline 39 & Peru Creek tributary 530 meters downstream of injection ${ }^{1}$ & $1 / 0$ & -- & 9.94 & $32.1 / 1.2$ & $0 / 1$ \\
\hline 41 & Saints John Creek at Montezuma & $22 / 4$ & 1,2 & $1-7$ & $57.3 / 2.2$ & $0 / 9$ \\
\hline 42 & Shoe Basin ditch water & $2 / 0$ & - & $14-24$ & $20.0 / 0.78$ & $1 / 2$ \\
\hline 43 & Shoe Basin surface water & $3 / 1$ & 1 & 2 & $48.8 / 1.9$ & $0 / 2$ \\
\hline 46 & Snake River above Deer Creek above Montezuma & $20 / 3$ & 1 & $1-2$ & $30.5 / 1.2$ & $0 / 7$ \\
\hline 48 & Snake River above Keystone & $32 / 29$ & 1 & $4-14$ & $33.2 / 1.3$ & $0 / 3$ \\
\hline 51 & Snake River at Keystone Science Center bridge & $1 / 0$ & -- & 1.7 & $31.8 / 1.2$ & $0 / 1$ \\
\hline 56 & Snake River downstream of confluence with Peru Creek & $2 / 1$ & 1.6 & 2.8 & $40.4 / 1.6$ & $0 / 1$ \\
\hline 63 & Snake River stream grab 1 (snowmaking intake) & $16 / 11$ & $0.2,1$ & $1-5$ & $31.5 / 1.2$ & $0 / 4$ \\
\hline - & Snake River stream grab 2 (snowmaking intake) & $4 / 2$ & 1 & $1-3$ & $30.8 / 1.2$ & $0 / 1$ \\
\hline $\mathbf{\square}$ & Snake River stream grab 3 (below snowmaking intake) & $4 / 3$ & 1 & 2 & $30.8 / 1.2$ & $0 / 1$ \\
\hline - & Snake River stream grab 4 (below snowmaking intake) & $4 / 2$ & 1 & 2 & $34.2 / 1.3$ & $0 / 1$ \\
\hline 70 & South Paymaster surface water & $6 / 1$ & 1 & $1-42$ & $7.0 / 0.27$ & $1 / 5$ \\
\hline \multicolumn{7}{|c|}{ Manganese, dissolved } \\
\hline 2 & Camp Creek stream grab 1 & $3 / 0$ & -- & 24-117 & 50 DWS (chronic) & 1 \\
\hline 3 & Camp Creek stream grab 2 & $19 / 1$ & 5 & $10-51$ & 50 DWS (chronic) & 1 \\
\hline 4 & Cinnamon Gulch & $1 / 0$ & -- & 2,785 & $2,124 / 1,174$ & $1 / 1$ \\
\hline 7 & Deer Creek above Montezuma at mouth & $21 / 1$ & 4 & $6-92$ & 50 DWS (chronic) & 1 \\
\hline${ }^{2} 26$ & Peru Creek below Pennsylvania Mine near Keystone & $1 / 0$ & -- & 1,500 & $2,417 / 1,335$ & $0 / 1$ \\
\hline 28 & Peru Creek downstream of Pennsylvania Mine & $3 / 0$ & -- & $648-1,663$ & $2,602 / 1,438$ & $0 / 1$ \\
\hline 32 & Peru Creek 139 meters downstream of injection ${ }^{1}$ & $6 / 0$ & -- & $1,509-1,571$ & $2,124 / 1,174$ & $0 / 6$ \\
\hline 33 & Peru Creek 251 meters downstream of injection ${ }^{1}$ & $7 / 0$ & -- & $1,788-1,814$ & $2,124 / 1,174$ & $0 / 7$ \\
\hline 34 & Peru Creek 485 meters downstream of injection ${ }^{1}$ & $6 / 0$ & -- & $2,325-2,387$ & $2,417 / 1,335$ & $0 / 6$ \\
\hline 35 & Peru Creek 583 meters downstream of injection ${ }^{1}$ & $7 / 0$ & -- & $2,299-2,552$ & $2,417 / 1,335$ & $1 / 7$ \\
\hline 36 & Peru Creek 824 meters downstream of injection ${ }^{1}$ & $5 / 0$ & -- & $2,291-2,400$ & $2,417 / 1,335$ & $0 / 5$ \\
\hline 37 & Peru Creek 908 meters downstream of injection ${ }^{1}$ & $5 / 0$ & -- & $2,334-2,412$ & $2,417 / 1,335$ & $0 / 5$ \\
\hline 38 & Peru Creek tributary 60 meters downstream of injection ${ }^{1}$ & $1 / 0$ & -- & 96,000 & $2,124 / 1,174$ & $1 / 1$ \\
\hline 39 & Peru Creek tributary 530 meters downstream of injection ${ }^{1}$ & $1 / 0$ & -- & 2,867 & $2,417 / 1,335$ & $1 / 1$ \\
\hline 41 & Saints John Creek at Montezuma & $21 / 0$ & -- & $118-1,300$ & 50 DWS (chronic) & 21 \\
\hline 44 & Snake River 300 feet above North Fork & $25 / 0$ & -- & $190-570$ & 50 DWS (chronic) & 25 \\
\hline 45 & Snake River above confluence with Deer Creek & $2 / 0$ & -- & $441-1,230$ & 50 DWS (chronic) & 2 \\
\hline 46 & Snake River above Deer Creek above Montezuma & $20 / 0$ & -- & $310-1,600$ & $\begin{array}{c}2,380 / 1,315 ; \\
50 \text { DWS (chronic) }\end{array}$ & $\begin{array}{c}0 / 2 \\
20 \text { chronic DWS }\end{array}$ \\
\hline 48 & Snake River above Keystone & $32 / 1$ & 4 & $5-670$ & 50 DWS (chronic) & 29 \\
\hline
\end{tabular}


Table 6. Exceedances of Colorado Department of Public Health and Environment in-stream water-quality standards for trace elements in the Snake River, upper Blue River, and Tenmile Creek subwatersheds and the lower Blue River watershed, Blue River watershed, Colorado, October 1995 through July 2006.—Continued

$[\mu \mathrm{g} / \mathrm{L}$, micrograms per liter; CDPHE, Colorado Department of Public Health and Environment; --, data not censored; DWS, domestic water supply. Range of concentration and number of samples with concentration greater than standard do not include samples with concentrations that were censored. Water-quality standards are from Colorado Department of Public Health and Environment (2008c, 2008d); standards are for protection of aquatic life unless otherwise stated. Site names without a site number (shown with an $\mathbf{\square}$ ) do not have latitude and longitude data available and are not shown in figure 15 or listed in Appendix 1]

\begin{tabular}{|c|c|c|c|c|c|c|}
\hline $\begin{array}{l}\text { Site number } \\
\text { in this report } \\
\text { (fig. 15; } \\
\text { Appendix 1) }\end{array}$ & $\begin{array}{c}\text { Site name } \\
\text { (fig. 15; Appendix 1) }\end{array}$ & $\begin{array}{l}\text { Number of } \\
\text { samples/ } \\
\text { number of } \\
\text { censored } \\
\text { values }\end{array}$ & $\begin{array}{l}\text { Censoring } \\
\text { limit }\end{array}$ & $\begin{array}{c}\text { Range of } \\
\text { concentration } \\
(\mu \mathrm{g} / \mathrm{L})\end{array}$ & $\begin{array}{c}\text { CDPHE } \\
\text { in-stream water- } \\
\text { quality standard } \\
\text { ( } \mu \mathrm{g} / \mathrm{L} \text { ) } \\
\text { (acute/chronic) }\end{array}$ & $\begin{array}{l}\text { Number of samples } \\
\text { with concentration } \\
\text { greater than } \\
\text { water-quality standard } \\
\text { (acute/chronic) }\end{array}$ \\
\hline \multicolumn{7}{|c|}{ Manganese, dissolved-Continued } \\
\hline 50 & Snake River at Keystone condos 075 miles below North Fork, below bridge & $25 / 0$ & -- & $140-410$ & 50 DWS (chronic) & 25 \\
\hline 51 & Snake River at Keystone Science Center bridge & $4 / 0$ & -- & $166-255$ & 50 DWS (chronic) & 4 \\
\hline 52 & Snake River at Montezuma & $30 / 0$ & -- & $99-650$ & 50 DWS (chronic) & 30 \\
\hline 53 & Snake R above confluence with Keystone Gulch & $5 / 0$ & -- & $214-261$ & 50 DWS (chronic) & 5 \\
\hline 54 & Snake River below Keystone, $\mathrm{CO}$ & $18 / 1$ & 4 & $5-277$ & 50 DWS (chronic) & 17 \\
\hline 55 & Snake River below mouth of Peru Creek & $7 / 0$ & -- & $319-697$ & 50 DWS (chronic) & 7 \\
\hline 56 & Snake River downstream of confluence with Peru Creek & $2 / 0$ & -- & $344-781$ & 50 DWS (chronic) & 2 \\
\hline 57 & Snake River downstream sample - just before Dillon Reservoir & $1 / 0$ & -- & 345 & 50 DWS (chronic) & 1 \\
\hline - & Snake River inlet at Dillon Reservoir & $11 / 0$ & -- & $81-364$ & 50 DWS (chronic) & 11 \\
\hline 58 & Snake River just before confluence with Peru Creek, background & $2 / 0$ & -- & $223-619$ & 50 DWS (chronic) & 2 \\
\hline 59 & Snake River just below confluence with Thurman Gulch & $1 / 0$ & -- & 716 & 50 DWS (chronic) & 1 \\
\hline 60 & Snake River near Montezuma, CO & $5 / 1$ & 4 & $5-440$ & 50 DWS (chronic) & 2 \\
\hline 63 & Snake River stream grab 1 (snowmaking intake) & $18 / 0$ & -- & $76-310$ & 50 DWS (chronic) & 18 \\
\hline - & Snake River stream grab 2 (snowmaking intake) & $3 / 0$ & -- & $345-541$ & 50 DWS (chronic) & 3 \\
\hline 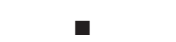 & Snake River stream grab 3 (below snowmaking intake) & $3 / 0$ & -- & $187-317$ & 50 DWS (chronic) & 3 \\
\hline$\square$ & Snake River stream grab 4 (below snowmaking intake) & $3 / 0$ & -- & $170-274$ & 50 DWS (chronic) & 3 \\
\hline 64 & Snake River upstream of Peru Creek confluence & $3 / 0$ & -- & $194-508$ & 50 DWS (chronic) & 3 \\
\hline 65 & Snake River above North Fork Snake River & $32 / 0$ & -- & $476-611$ & 50 DWS (chronic) & 32 \\
\hline 66 & Snake River below North Fork Snake River & $32 / 0$ & -- & $281-383$ & 50 DWS (chronic) & 32 \\
\hline 69 & Soda Creek downstream Snake River wasterwater treatment plant & $5 / 0$ & -- & $17-190$ & 50 DWS (chronic) & 2 \\
\hline \multicolumn{7}{|c|}{ e } \\
\hline 46 & Snake River above Deer Creek above Montezuma & $19 / 18$ & $0.1,0.2$ & 0.1 & 0.01 (chronic) & 1 \\
\hline 59 & Snake River just below confluence with Thurman Gulch & $1 / 0$ & -- & 0.11 & 0.01 (chronic) & 1 \\
\hline \multicolumn{7}{|c|}{ Selenium, dissolved } \\
\hline 24 & Peru Creek at mouth near Montezuma, CO & $3 / 1$ & 0.2 & $0.2-14.5$ & $18.4 / 4.6$ & $0 / 1$ \\
\hline 28 & Peru Creek downstream of Pennsylvania Mine & $3 / 1$ & 0.2 & $12.3-17.8$ & $18.4 / 4.6$ & $0 / 2$ \\
\hline 29 & Peru Creek upstream of Pennsylvania Mine & $2 / 0$ & -- & $0.3-12.4$ & $18.4 / 4.6$ & $0 / 1$ \\
\hline 41 & Saints John Creek at Montezuma & $22 / 20$ & $0.2,1$ & $11.4-14.9$ & $18.4 / 4.6$ & $0 / 2$ \\
\hline 45 & Snake River above confluence with Deer Creek & $2 / 1$ & 0.2 & 21.7 & $18.4 / 4.6$ & $1 / 1$ \\
\hline 55 & Snake River below mouth of Peru Creek & $4 / 2$ & 0.2 & $9.9-15.8$ & $18.4 / 4.6$ & $0 / 2$ \\
\hline 64 & Snake River upstream of Peru Creek confluence & $3 / 1$ & 0.2 & $13.4-15.7$ & $18.4 / 4.6$ & $0 / 2$ \\
\hline \multicolumn{7}{|c|}{ Silver, dissolved } \\
\hline 16 & National Treasury surface water & $4 / 3$ & 0.2 & 0.5 & $1.2 / 0.05$ & $0 / 1$ \\
\hline 40 & Peruvian surface water & $2 / 1$ & 0.2 & 0.7 & $1.5 / 0.05$ & $0 / 1$ \\
\hline 52 & Snake River at Montezuma & $30 / 29$ & $0.2,0.3$ & 0.3 & $0.71 / 0.03$ & $0 / 1$ \\
\hline 70 & South Paymaster surface water & $6 / 5$ & 0.2 & 0.8 & $0.07 / 0.002$ & $1 / 1$ \\
\hline
\end{tabular}


Table 6. Exceedances of Colorado Department of Public Health and Environment in-stream water-quality standards for trace elements in the Snake River, upper Blue River, and Tenmile Creek subwatersheds and the lower Blue River watershed, Blue River watershed, Colorado, October 1995 through July 2006.—Continued

$[\mu \mathrm{g} / \mathrm{L}$, micrograms per liter; CDPHE, Colorado Department of Public Health and Environment; --, data not censored; DWS, domestic water supply. Range of concentration and number of samples with concentration greater than standard do not include samples with concentrations that were censored. Water-quality standards are from Colorado Department of Public Health and Environment (2008c, 2008d); standards are for protection of aquatic life unless otherwise stated. Site names without a site number (shown with an $\mathbf{\square}$ ) do not have latitude and longitude data available and are not shown in figure 15 or listed in Appendix 1]

\begin{tabular}{|c|c|c|c|c|c|c|}
\hline $\begin{array}{l}\text { Site number } \\
\text { in this report } \\
\text { (fig. 15; } \\
\text { Appendix 1) }\end{array}$ & $\begin{array}{c}\text { Site name } \\
\text { (fig. 15; Appendix 1) }\end{array}$ & $\begin{array}{c}\text { Number of } \\
\text { samples/ } \\
\text { number of } \\
\text { censored } \\
\text { values } \\
\end{array}$ & $\begin{array}{l}\text { Censoring } \\
\text { limit }\end{array}$ & $\begin{array}{c}\text { Range of } \\
\text { concentration } \\
(\mu \mathrm{g} / \mathrm{L})\end{array}$ & $\begin{array}{c}\text { CDPHE } \\
\text { in-stream water- } \\
\text { quality standard } \\
\text { ( } \mu \mathrm{g} / \mathrm{L} \text { ) } \\
\text { (acute/chronic) }\end{array}$ & $\begin{array}{l}\text { Number of samples } \\
\text { with concentration } \\
\text { greater than } \\
\text { water-quality standard } \\
\text { (acute/chronic) } \\
\end{array}$ \\
\hline \multicolumn{7}{|c|}{ Zinc, dissolved } \\
\hline 2 & Camp Creek stream grab 1 & $3 / 0$ & -- & $20-200$ & $121 / 103$ & $1 / 1$ \\
\hline 4 & Cinnamon Gulch & $1 / 0$ & -- & 1,670 & $60.0 / 52.0$ & $1 / 1$ \\
\hline 7 & Deer Creek above Montezuma at mouth & $20 / 0$ & -- & $11-130$ & $64.8 / 56.2$ & $4 / 5$ \\
\hline 11 & Keystone Gulch near Dillon, CO & $15 / 0$ & -- & $1-61$ & $50.6 / 6.91$ & $1 / 12$ \\
\hline 16 & National Treasury surface water & $3 / 0$ & -- & $53-537$ & $112 / 97.4$ & $1 / 1$ \\
\hline 19 & North Fork Snake River near mouth & $12 / 10$ & 10 & $21-23$ & $64.2 / 12.9$ & $0 / 2$ \\
\hline 20 & Peru Creek 01 mile upstream of confluence with Snake River & $2 / 0$ & -- & 444-983 & $82.1 / 71.2$ & $2 / 2$ \\
\hline 21 & Peru Creek above Snake River & $1 / 0$ & -- & 1,071 & $82.1 / 71.2$ & $1 / 1$ \\
\hline 23 & Peru Creek at mouth & $25 / 0$ & -- & $140-1,500$ & $86.4 / 74.9$ & $25 / 25$ \\
\hline 24 & Peru Creek at mouth near Montezuma, $\mathrm{CO}$ & $4 / 0$ & -- & $378-1,196$ & $93.1 / 80.8$ & $4 / 4$ \\
\hline 25 & Peru Creek at Peru Creek below FR 214 & $3 / 0$ & -- & $1,370-1,394$ & $93.1 / 80.8$ & $3 / 3$ \\
\hline 226 & Peru Creek below Pennsylvania Mine near Keystone & $1 / 0$ & -- & 2,000 & $83.4 / 72.3$ & $1 / 1$ \\
\hline 227 & Peru Creek below Shoe Basin input (high flow sample site) & $1 / 0$ & -- & 93 & $67.7 / 58.7$ & $1 / 1$ \\
\hline 28 & Peru Creek downstream of Pennsylvania Mine & $3 / 0$ & -- & $631-1,878$ & $101 / 87.4$ & $3 / 3$ \\
\hline 29 & Peru Creek upstream of Pennsylvania Mine & $2 / 0$ & -- & $108-168$ & $87.2 / 75.6$ & $2 / 2$ \\
\hline 230 & Peru Creek 0 meters downstream of injection ${ }^{1}$ & $1 / 0$ & -- & 236 & $60.0 / 52.0$ & $1 / 1$ \\
\hline 31 & Peru Creek 51 meters downstream of injection ${ }^{1}$ & $7 / 0$ & -- & $216-237$ & $60.0 / 52.0$ & $7 / 7$ \\
\hline 32 & Peru Creek 139 meters downstream of injection ${ }^{1}$ & $6 / 0$ & -- & $1,632-1,704$ & $60.0 / 52.0$ & $6 / 6$ \\
\hline 33 & Peru Creek 251 meters downstream of injection ${ }^{1}$ & $7 / 0$ & -- & $2,201-2,295$ & $60.0 / 52.0$ & $7 / 7$ \\
\hline 34 & Peru Creek 485 meters downstream of injection ${ }^{1}$ & $6 / 0$ & -- & $2,637-2,766$ & $83.4 / 72.3$ & $6 / 6$ \\
\hline 35 & Peru Creek 583 meters downstream of injection ${ }^{1}$ & $7 / 0$ & -- & $2,588-2,831$ & $83.4 / 72.3$ & $7 / 7$ \\
\hline 36 & Peru Creek 824 meters downstream of injection ${ }^{1}$ & $5 / 0$ & -- & $2,762-2,814$ & $83.4 / 72.3$ & $5 / 5$ \\
\hline 37 & Peru Creek 908 meters downstream of injection ${ }^{1}$ & $5 / 0$ & -- & $2,585-2,682$ & $83.4 / 72.3$ & $5 / 5$ \\
\hline 38 & Peru Creek tributary 60 meters downstream of injection ${ }^{1}$ & $1 / 0$ & -- & 101,000 & $60.0 / 52.0$ & $1 / 1$ \\
\hline 39 & Peru Creek tributary 530 meters downstream of injection ${ }^{1}$ & $1 / 0$ & -- & 1,927 & $83.4 / 72.3$ & $1 / 1$ \\
\hline 40 & Peruvian surface water & $2 / 0$ & -- & $26-112$ & $121 / 105$ & $0 / 1$ \\
\hline 41 & Saints John Creek at Montezuma & $21 / 0$ & -- & $138-830$ & $131 / 113$ & $21 / 21$ \\
\hline 42 & Shoe Basin ditch water & $2 / 0$ & -- & $28-57$ & $58.0 / 50.3$ & $0 / 1$ \\
\hline 43 & Shoe Basin surface water & $3 / 0$ & -- & $51-117$ & $115 / 99.9$ & $1 / 1$ \\
\hline 44 & Snake River 300 feet above North Fork & $25 / 0$ & -- & $240-690$ & $81.2 / 70.4$ & $25 / 25$ \\
\hline 45 & Snake River above confluence with Deer Creek & $2 / 0$ & -- & $304-703$ & $85.2 / 73.9$ & $2 / 2$ \\
\hline 46 & Snake River above Deer Creek above Montezuma & $20 / 0$ & -- & $340-960$ & $80.2 / 69.5$ & $20 / 20$ \\
\hline 48 & Snake River above Keystone & $32 / 3$ & 8 & $240-780$ & $85.4 / 74.1$ & $29 / 29$ \\
\hline 50 & Snake River at Keystone condos 075 miles below North Fork, below bridge & $25 / 0$ & -- & $150-470$ & $75.7 / 65.7$ & $25 / 25$ \\
\hline 51 & Snake River at Keystone Science Center bridge & $5 / 0$ & -- & $272-308$ & $82.8 / 71.8$ & $5 / 5$ \\
\hline 52 & Snake River at Montezuma & $29 / 0$ & -- & $100-640$ & $85.0 / 73.7$ & $29 / 29$ \\
\hline
\end{tabular}


Table 6. Exceedances of Colorado Department of Public Health and Environment in-stream water-quality standards for trace elements in the Snake River, upper Blue River, and Tenmile Creek subwatersheds and the lower Blue River watershed, Blue River watershed, Colorado, October 1995 through July 2006.—Continued

$[\mu \mathrm{g} / \mathrm{L}$, micrograms per liter; CDPHE, Colorado Department of Public Health and Environment; --, data not censored; DWS, domestic water supply. Range of concentration and number of samples with concentration greater than standard do not include samples with concentrations that were censored. Water-quality standards are from Colorado Department of Public Health and Environment (2008c, 2008d); standards are for protection of aquatic life unless otherwise stated. Site names without a site number (shown with an $\mathbf{\square}$ ) do not have latitude and longitude data available and are not shown in figure 15 or listed in Appendix 1]

\begin{tabular}{|c|c|c|c|c|c|c|}
\hline $\begin{array}{l}\text { Site number } \\
\text { in this report } \\
\text { (fig. 15; } \\
\text { Appendix 1) }\end{array}$ & $\begin{array}{c}\text { Site name } \\
\text { (fig. 15; Appendix 1) }\end{array}$ & $\begin{array}{c}\text { Number of } \\
\text { samples/ } \\
\text { number of } \\
\text { censored } \\
\text { values }\end{array}$ & $\begin{array}{l}\text { Censoring } \\
\text { limit }\end{array}$ & $\begin{array}{c}\text { Range of } \\
\text { concentration } \\
(\mu \mathrm{g} / \mathrm{L})\end{array}$ & $\begin{array}{c}\text { CDPHE } \\
\text { in-stream water- } \\
\text { quality standard } \\
\text { ( } \mu \mathrm{g} / \mathrm{L} \text { ) } \\
\text { (acute/chronic) }\end{array}$ & $\begin{array}{c}\text { Number of samples } \\
\text { with concentration } \\
\text { greater than } \\
\text { water-quality standard } \\
\text { (acute/chronic) }\end{array}$ \\
\hline \multicolumn{7}{|c|}{ Zinc, dissolved-Continued } \\
\hline 53 & Snake R above confluence with Keystone Gulch & $5 / 0$ & -- & $295-366$ & $80.1 / 69.4$ & $5 / 5$ \\
\hline 54 & Snake River below Keystone, $\mathrm{CO}$ & $16 / 1$ & 8 & $139-306$ & $71.5 / 62.0$ & $15 / 15$ \\
\hline 55 & Snake River below mouth of Peru Creek & $5 / 0$ & -- & $352-853$ & $99.6 / 86.3$ & $5 / 5$ \\
\hline 56 & Snake River downstream of confluence with Peru Creek & $2 / 0$ & -- & $349-861$ & $99.6 / 86.3$ & $2 / 2$ \\
\hline 57 & Snake River downstream sample - just before Dillon Reservoir & $1 / 0$ & -- & 305 & $71.5 / 62.0$ & $1 / 1$ \\
\hline - & Snake River inlet at Dillon Reservoir & $9 / 0$ & -- & $148-321$ & $86.1 / 74.7$ & $9 / 9$ \\
\hline 58 & Snake River just before confluence with Peru Creek, background & $2 / 0$ & -- & $179-525$ & $94.1 / 81.6$ & $2 / 2$ \\
\hline 59 & Snake River just below confluence with Thurman Gulch & $1 / 0$ & -- & 790 & $99.6 / 86.3$ & $1 / 1$ \\
\hline 60 & Snake River near Montezuma, CO & $5 / 3$ & 8 & $240-330$ & $69.1 / 59.9$ & $2 / 2$ \\
\hline 63 & Snake River stream grab 1 (snowmaking intake) & $20 / 0$ & -- & $19-400$ & $82.1 / 71.2$ & $19 / 19$ \\
\hline - & Snake River stream grab 2 (snowmaking intake) & $4 / 0$ & -- & $440-660$ & $80.7 / 70.0$ & $4 / 4$ \\
\hline - & Snake River stream grab 3 (below snowmaking intake) & $4 / 0$ & -- & $250-390$ & $80.7 / 70.0$ & $4 / 4$ \\
\hline - & Snake River stream grab 4 (below snowmaking intake) & $4 / 0$ & -- & $220-360$ & $87.4 / 75.8$ & $4 / 4$ \\
\hline 64 & Snake River upstream of Peru Creek confluence & $3 / 0$ & -- & $256-500$ & $102 / 88.1$ & $3 / 3$ \\
\hline 65 & Snake River above North Fork Snake River & $32 / 0$ & -- & $483-649$ & $81.8 / 70.9$ & $32 / 32$ \\
\hline 66 & Snake River below North Fork Snake River & $32 / 0$ & -- & $276-387$ & $74.1 / 64.2$ & $32 / 32$ \\
\hline 70 & South Paymaster surface water & $6 / 3$ & 5 & 89-514 & $26.2 / 22.7$ & $3 / 3$ \\
\hline \multicolumn{7}{|c|}{ Upper Blue River subwatershed } \\
\hline \multicolumn{7}{|c|}{ Cadmium, dissolved } \\
\hline 74 & Blue River above Dillon Reservoir & $47 / 35$ & $\begin{array}{c}0.25,0.3 \\
0.6\end{array}$ & $0.04-1.3$ & $1.3 / 0.34$ & $0 / 6$ \\
\hline 75 & Blue River above French Gulch & $17 / 14$ & $\begin{array}{c}0.05,0.1 \\
0.2,0.4 \\
0.5,3\end{array}$ & $0.1-0.5$ & $1.1 / 0.29$ & $0 / 1$ \\
\hline 76 & Blue River above Iowa Hill Sanitation District & $37 / 3$ & 0.1 & $0.15-6$ & $4 / 4$ & $17 / 17$ \\
\hline 77 & Blue River above North Park Avenue Bridge & $25 / 20$ & $0.1,15$ & $0.11-0.3$ & $1.1 / 0.29$ & $0 / 1$ \\
\hline 278 & Blue River above town of Blue River & $28 / 27$ & $0.25,0.3$ & 0.37 & $1 / 3 / 0.35$ & $0 / 1$ \\
\hline 84 & Blue River below French Gulch near Breckenridge & $23 / 1$ & 0.6 & $0.6-8.2$ & $4 / 4$ & $7 / 7$ \\
\hline 85 & Blue River near Breckenridge near Cty Road 3 & $24 / 0$ & -- & $0.77-6.66$ & $4 / 4$ & $4 / 4$ \\
\hline 86 & Blue River near Dillon, CO & $22 / 20$ & $0.25,1$ & $0.27-0.66$ & $1.2 / 0.31$ & $0 / 1$ \\
\hline 90 & French Gulch above Gibson Gulch & $8 / 0$ & -- & $6.0-17.8$ & ${ }^{3} 8.17 / 8.17$ & $4 / 0$ \\
\hline 92 & French Gulch abv Wellington Mine & $13 / 7$ & $\begin{array}{c}0.2,0.4 \\
0.5,1\end{array}$ & $0.1-0.3$ & $0.88 / 0.24$ & $0 / 3$ \\
\hline 93 & French Gulch at Breckenridge & $81 / 0$ & -- & $2.8-11.0$ & ${ }^{3} 8.17 / 8.17$ & $14 / 14$ \\
\hline 94 & Illinois Gulch at Breckenridge Ice Rink & $13 / 2$ & 0.6 & $0.6-3.1$ & $1.9 / 0.47$ & $3 / 11$ \\
\hline
\end{tabular}


Table 6. Exceedances of Colorado Department of Public Health and Environment in-stream water-quality standards for trace elements in the Snake River, upper Blue River, and Tenmile Creek subwatersheds and the lower Blue River watershed, Blue River watershed, Colorado, October 1995 through July 2006.—Continued

$[\mu \mathrm{g} / \mathrm{L}$, micrograms per liter; CDPHE, Colorado Department of Public Health and Environment; --, data not censored; DWS, domestic water supply. Range of concentration and number of samples with concentration greater than standard do not include samples with concentrations that were censored. Water-quality standards are from Colorado Department of Public Health and Environment (2008c, 2008d); standards are for protection of aquatic life unless otherwise stated. Site names without a site number (shown with an $\mathbf{\square}$ ) do not have latitude and longitude data available and are not shown in figure 15 or listed in Appendix 1]

\begin{tabular}{|c|c|c|c|c|c|c|}
\hline $\begin{array}{l}\text { Site number } \\
\text { in this report } \\
\text { (fig. 15; } \\
\text { Appendix 1) }\end{array}$ & $\begin{array}{c}\text { Site name } \\
\text { (fig. 15; Appendix 1) }\end{array}$ & $\begin{array}{l}\text { Number of } \\
\text { samples/ } \\
\text { number of } \\
\text { censored } \\
\text { values }\end{array}$ & $\begin{array}{l}\text { Censoring } \\
\text { limit }\end{array}$ & $\begin{array}{c}\text { Range of } \\
\text { concentration } \\
(\mu \mathrm{g} / \mathrm{L})\end{array}$ & $\begin{array}{c}\text { CDPHE } \\
\text { in-stream water- } \\
\text { quality standard } \\
\text { ( } \mu \mathrm{g} / \mathrm{L} \text { ) } \\
\text { (acute/chronic) }\end{array}$ & $\begin{array}{l}\text { Number of samples } \\
\text { with concentration } \\
\text { greater than } \\
\text { water-quality standard } \\
\text { (acute/chronic) }\end{array}$ \\
\hline \multicolumn{7}{|c|}{ Chromium, dissolved } \\
\hline 93 & French Gulch at Breckenridge & $67 / 59$ & $0.2,1,2,4$ & $0.3-89$ & $16 / 11$ & $2 / 2$ \\
\hline \multicolumn{7}{|c|}{ Copper, dissolved } \\
\hline 72 & $\begin{array}{l}\text { Blue River above Breckenridge and Highway } 9 \text { bridge and below Goose } \\
\text { Pasture Tarn }\end{array}$ & $22 / 12$ & 1 & $1.2-18.5$ & $11.4 / 7.7$ & $3 / 4$ \\
\hline 77 & Blue River above North Park Avenue Bridge & $18 / 5$ & 1 & $1.1-16.5$ & $8.3 / 5.8$ & $3 / 3$ \\
\hline 278 & Blue River above town of Blue River & $28 / 26$ & 3,4 & $5-8$ & $10.4 / 7.1$ & $0 / 1$ \\
\hline 83 & Blue River at Highway 9 above Swan River & $34 / 9$ & $0.8,1,5$ & $1.0-16.0$ & $10.1 / 6.9$ & $1 / 6$ \\
\hline 85 & Blue River near Breckenridge near Cty Road 3 & $21 / 6$ & 1 & $1.0-27.4$ & $16.6 / 10.8$ & $1 / 1$ \\
\hline 89 & French Gulch above confluence with Dead Elk Pond & $11 / 4$ & $0.8,1,5$ & $1.0-10$ & $8.5 / 5.9$ & $1 / 1$ \\
\hline 90 & French Gulch above Gibson Gulch & $13 / 2$ & $0.8,1$ & $2.0-9.0$ & $8.5 / 5.9$ & $2 / 5$ \\
\hline \multicolumn{7}{|c|}{ Iron, total recoverable } \\
\hline 83 & Blue River at Highway 9 above Swan River & $36 / 14$ & $10,50,100$ & $20-1,256$ & 1,000 (chronic) & 1 \\
\hline - & Blue River inlet at Dillon Reservoir & $11 / 0$ & -- & $20-1,080$ & 1,000 (chronic) & 1 \\
\hline 85 & Blue River near Breckenridge near Cty Road 3 & $25 / 13$ & 10,50 & $109-1,832$ & 1,000 (chronic) & 1 \\
\hline 86 & Blue River near Dillon, CO & $19 / 2$ & 10,100 & $13-1,610$ & 1,000 (chronic) & 1 \\
\hline 94 & Illinois Gulch at Breckenridge Ice Rink & $13 / 0$ & -- & $34-1,400$ & 1,000 (chronic) & 1 \\
\hline 96 & Tributary to mine drain ditch above confluence & $2 / 0$ & -- & $2,689-8,251$ & 1,000 (chronic) & 2 \\
\hline \multicolumn{7}{|c|}{ Lead, dissolved } \\
\hline 74 & Blue River above Dillon Reservoir & $47 / 44$ & $0.1,1$ & $1-13$ & $46.3 / 1.8$ & $0 / 1$ \\
\hline 76 & Blue River above Iowa Hill Sanitation District & $25 / 1$ & 50 & $2-21$ & $57.6 / 2.2$ & $0 / 20$ \\
\hline${ }^{2} 78$ & Blue River above town of Blue River & $28 / 27$ & $0.1,1$ & 2 & $47.9 / 1.9$ & $0 / 1$ \\
\hline 84 & Blue River below French Gulch near Breckenridge & $23 / 4$ & $0.8,1,40$ & $0.3-5.8$ & $54.8 / 2.1$ & $0 / 5$ \\
\hline 91 & French Gulch above Rich Gulch near Lincoln & $5 / 4$ & $0.8,1$ & 3.6 & $28.8 / 1.1$ & $0 / 1$ \\
\hline 93 & French Gulch at Breckenridge & $81 / 8$ & 1,40 & $1.04-8$ & ${ }^{3} 5.0 / 5.0$ & $17 / 17$ \\
\hline 94 & Illinois Gulch at Breckenridge Ice Rink & $13 / 11$ & 1 & $2-3$ & $74.5 / 2.9$ & $0 / 1$ \\
\hline \multicolumn{7}{|c|}{ Manganese, dissolved } \\
\hline 76 & Blue River above Iowa Hill Sanitation District & $36 / 0$ & -- & $5-110$ & 50 DWS (chronic) & 3 \\
\hline 84 & Blue River below French Gulch near Breckenridge & $23 / 0$ & -- & $9.7-91$ & 50 DWS (chronic) & 5 \\
\hline 85 & Blue River near Breckenridge near Cty Road 3 & $25 / 7$ & 10,20 & $16-98$ & 50 DWS (chronic) & 3 \\
\hline 90 & French Gulch above Gibson Gulch & $15 / 0$ & -- & $402-4,590$ & $2,542 / 1,404$ & $9 / 10$ \\
\hline 94 & Illinois Gulch at Breckenridge Ice Rink & $13 / 0$ & -- & $13-270$ & 50 DWS (chronic) & 9 \\
\hline \multicolumn{7}{|c|}{ Nickel, dissolved } \\
\hline 93 & French Gulch at Breckenridge & $71 / 11$ & 2,10 & $1.16-85$ & $587 / 65.2$ & $0 / 1$ \\
\hline
\end{tabular}


Table 6. Exceedances of Colorado Department of Public Health and Environment in-stream water-quality standards for trace elements in the Snake River, upper Blue River, and Tenmile Creek subwatersheds and the lower Blue River watershed, Blue River watershed, Colorado, October 1995 through July 2006.-Continued

[ $\mu \mathrm{g} / \mathrm{L}$, micrograms per liter; CDPHE, Colorado Department of Public Health and Environment; --, data not censored; DWS, domestic water supply. Range of concentration and number of samples with concentration greater than standard do not include samples with concentrations that were censored. Water-quality standards are from Colorado Department of Public Health and Environment (2008c, 2008d); standards are for protection of aquatic life unless otherwise stated. Site names without a site number (shown with an $\mathbf{m}$ ) do not have latitude and longitude data available and are not shown in figure 15 or listed in Appendix 1]

\begin{tabular}{|c|c|c|c|c|c|c|}
\hline $\begin{array}{l}\text { Site number } \\
\text { in this report } \\
\text { (fig. 15; } \\
\text { Appendix 1) }\end{array}$ & $\begin{array}{c}\text { Site name } \\
\text { (fig. 15; Appendix 1) }\end{array}$ & $\begin{array}{c}\text { Number of } \\
\text { samples/ } \\
\text { number of } \\
\text { censored } \\
\text { values }\end{array}$ & $\begin{array}{l}\text { Censoring } \\
\text { limit }\end{array}$ & $\begin{array}{c}\text { Range of } \\
\text { concentration } \\
(\mu \mathrm{g} / \mathrm{L})\end{array}$ & $\begin{array}{c}\text { CDPHE } \\
\text { in-stream water- } \\
\text { quality standard } \\
\text { ( } \mu \mathrm{g} / \mathrm{L} \text { ) } \\
\text { (acute/chronic) } \\
\end{array}$ & $\begin{array}{l}\text { Number of samples } \\
\text { with concentration } \\
\text { greater than } \\
\text { water-quality standard } \\
\text { (acute/chronic) }\end{array}$ \\
\hline \multicolumn{7}{|c|}{ Silver, dissolved } \\
\hline 76 & Blue River above Iowa Hill Sanitation District & $14 / 9$ & $0.1,0.5,5$ & $0.12-5.5$ & $1.69 / 0.06$ & $4 / 5$ \\
\hline \multicolumn{7}{|c|}{ Zinc, dissolved } \\
\hline 71 & Blue River 4 miles downstream of Breckenridge, $\mathrm{CO}$ & $1 / 0$ & -- & 117 & $101 / 41.5$ & $1 / 1$ \\
\hline 73 & Blue River above confluence Dillon Reservoir & $1 / 0$ & -- & 98.7 & $106 / 47.9$ & $0 / 1$ \\
\hline 74 & Blue River above Dillon Reservoir & $47 / 10$ & 10 & $10-88$ & $111 / 53.1$ & $0 / 8$ \\
\hline 75 & Blue River above French Gulch & $15 / 1$ & 10 & $10-80$ & $92.7 / 33.6$ & $0 / 1$ \\
\hline 76 & Blue River above Iowa Hill Sanitation District & $18 / 0$ & -- & $5.6-2,000$ & $616 / 616$ & $10 / 10$ \\
\hline 77 & Blue River above North Park Avenue Bridge & $21 / 6$ & 1,10 & $10-51$ & $92.7 / 33.6$ & $0 / 4$ \\
\hline 84 & Blue River below French Gulch near Breckenridge & $23 / 0$ & -- & $290-4,070$ & $582 / 582$ & $18 / 18$ \\
\hline - & Blue River inlet at Dillon Reservoir & $9 / 0$ & -- & $13-69$ & $115 / 59.0$ & $0 / 1$ \\
\hline 85 & Blue River near Breckenridge near Cty Road 3 & $25 / 0$ & -- & $313-3,780$ & $929 / 929$ & $15 / 15$ \\
\hline 86 & Blue River near Dillon, CO & $21 / 0$ & -- & $13-124$ & $102 / 43.1$ & $1 / 13$ \\
\hline 87 & French Creek above Blue River & $1 / 0$ & -- & 5,260 & ${ }^{3} 4,137 / 4,137$ & $1 / 1$ \\
\hline 90 & French Gulch above Gibson Gulch & $15 / 0$ & -- & $1,710-15,500$ & ${ }^{3} 4,137 / 4,137$ & $11 / 11$ \\
\hline 93 & French Gulch at Breckenridge & $83 / 0$ & -- & $1,140-4,450$ & ${ }^{3} 4,137 / 4,137$ & $7 / 7$ \\
\hline 94 & Illinois Gulch at Breckenridge Ice Rink & $13 / 0$ & -- & $150-1,300$ & $160 / 140$ & $12 / 13$ \\
\hline \multicolumn{7}{|c|}{ Tenmile Creek subwatershed } \\
\hline \multicolumn{7}{|c|}{$\begin{array}{ll} & \text { Cadmium, dissolved }\end{array}$} \\
\hline 97 & Ten Mile Creek above Wheeler Junction near Copper Mountain & $27 / 12$ & $0.3,0.6$ & $0.3-1.8$ & $7.6 / 1.5$ & $0 / 2$ \\
\hline 100 & Tenmile Creek at 4th Street at Frisco & $8 / 7$ & 1 & 1 & $4.5 / 0.98$ & $0 / 1$ \\
\hline 103 & Tenmile Creek at Kokomo, $\mathrm{CO}$ & $3 / 2$ & 0.25 & 1.3 & $4.0 / 0.89$ & $0 / 1$ \\
\hline${ }^{2} 109$ & West Tenmile Creek below Copper & $21 / 19$ & $\begin{array}{c}0.25,0.3 \\
0.6\end{array}$ & $0.9-2.1$ & $1.5 / 0.38$ & $1 / 2$ \\
\hline \multicolumn{7}{|c|}{ Iron, total recoverable } \\
\hline 102 & Tenmile Creek at inlet & $19 / 0$ & -- & $106-1,578$ & 1,000 (chronic) & 1 \\
\hline \multicolumn{7}{|c|}{ Lead, dissolved } \\
\hline 97 & Ten Mile Creek above Wheeler Junction near Copper Mountain & $27 / 26$ & 1,2 & 16 & $392 / 15.3$ & $0 / 1$ \\
\hline${ }^{2} 109$ & West Tenmile Creek below Copper & $21 / 20$ & 1 & 11 & $54.6 / 2.1$ & $0 / 1$ \\
\hline
\end{tabular}


Table 6. Exceedances of Colorado Department of Public Health and Environment in-stream water-quality standards for trace elements in the Snake River, upper Blue River, and Tenmile Creek subwatersheds and the lower Blue River watershed, Blue River watershed, Colorado, October 1995 through July 2006.—Continued

$[\mu \mathrm{g} / \mathrm{L}$, micrograms per liter; CDPHE, Colorado Department of Public Health and Environment; --, data not censored; DWS, domestic water supply. Range of concentration and number of samples with concentration greater than standard do not include samples with concentrations that were censored. Water-quality standards are from Colorado Department of Public Health and Environment (2008c, 2008d); standards are for protection of aquatic life unless otherwise stated. Site names without a site number (shown with an $\mathbf{m}$ ) do not have latitude and longitude data available and are not shown in figure 15 or listed in Appendix 1]

\begin{tabular}{|c|c|c|c|c|c|c|}
\hline $\begin{array}{l}\text { Site number } \\
\text { in this report } \\
\text { (fig. 15; } \\
\text { Appendix 1) }\end{array}$ & $\begin{array}{c}\text { Site name } \\
\text { (fig. 15; Appendix 1) }\end{array}$ & $\begin{array}{c}\text { Number of } \\
\text { samples/ } \\
\text { number of } \\
\text { censored } \\
\text { values } \\
\end{array}$ & $\begin{array}{l}\text { Censoring } \\
\text { limit }\end{array}$ & $\begin{array}{c}\text { Range of } \\
\text { concentration } \\
(\mu \mathrm{g} / \mathrm{L})\end{array}$ & $\begin{array}{c}\text { CDPHE } \\
\text { in-stream water- } \\
\text { quality standard } \\
\text { ( } \mu \mathrm{g} / \mathrm{L} \text { ) } \\
\text { (acute/chronic) }\end{array}$ & $\begin{array}{l}\text { Number of samples } \\
\text { with concentration } \\
\text { greater than } \\
\text { water-quality standard } \\
\text { (acute/chronic) } \\
\end{array}$ \\
\hline \multicolumn{7}{|c|}{ Manganese, dissolved } \\
\hline 98 & Tenmile Creek above Frisco & $1 / 0$ & -- & 480 & 50 DWS (chronic) & 1 \\
\hline 99 & Tenmile Creek above West Fork & $1 / 0$ & -- & 1,100 & 50 DWS (chronic) & 1 \\
\hline 100 & Tenmile Creek at 4th Street at Frisco & $5 / 0$ & -- & $16-386$ & 50 DWS (chronic) & 2 \\
\hline 101 & Tenmile Creek at Frisco & $8 / 0$ & -- & $24-230$ & 50 DWS (chronic) & 5 \\
\hline 104 & Tenmile Creek below North Tenmile Creek, at Frisco & $1 / 0$ & -- & 54.6 & 50 DWS (chronic) & 1 \\
\hline - & Tenmile Creek inlet at Dillon Reservoir & $11 / 0$ & -- & $26-354$ & 50 DWS (chronic) & 9 \\
\hline \multicolumn{7}{|c|}{ Lower Blue River subwatershed } \\
\hline \multicolumn{7}{|c|}{ Cadmium, dissolved } \\
\hline 112 & Blue River at Grand $\mathrm{Cr} 10$ bridge & $4 / 3$ & 0.6 & 0.9 & $1.5 / 0.39$ & $0 / 1$ \\
\hline \multicolumn{7}{|c|}{ Copper, dissolved } \\
\hline 125 & Straight Creek 13 miles above diversion structure & $17 / 13$ & $0.002,5,6$ & $3-7$ & $9.4 / 6.5$ & $0 / 3$ \\
\hline 130 & Straight Creek below diversion structure & $17 / 13$ & $0.002,5,6$ & $4-8$ & $8.9 / 6.2$ & $0 / 2$ \\
\hline \multicolumn{7}{|c|}{ Iron, total recoverable } \\
\hline 111 & Blue River at City Road 1 & $21 / 0$ & -- & $24-1,200$ & 1,000 (chronic) & 1 \\
\hline ! & Blue River outlet at Dillon Reservoir & $10 / 0$ & -- & $10-2,900$ & 1,000 (chronic) & 1 \\
\hline 124 & Spruce Creek at CR 10 & $2 / 0$ & -- & $760-1,200$ & 1,000 (chronic) & 1 \\
\hline 128 & Straight Creek above the town of Dillon & $21 / 0$ & -- & $24-1,200$ & 1,000 (chronic) & 1 \\
\hline \multicolumn{7}{|c|}{ Lead, dissolved } \\
\hline 112 & Blue River at Grand Cr 10 bridge & $4 / 3$ & 1 & 10 & $56.5 / 2.2$ & $0 / 1$ \\
\hline \multicolumn{7}{|c|}{ Manganese, dissolved } \\
\hline 111 & Blue River at City Road 1 & $20 / 0$ & -- & $5-90$ & 50 DWS (chronic) & 3 \\
\hline \multicolumn{7}{|c|}{ Zinc, dissolved } \\
\hline${ }^{2} 117$ & Blue River below Dillon Reservoir & $29 / 3$ & 8,10 & $20-600$ & $132 / 83.9$ & $1 / 1$ \\
\hline 128 & Straight Creek above the town of Dillon & $21 / 5$ & 8,10 & $10-88$ & $77.5 / 67.2$ & $1 / 1$ \\
\hline
\end{tabular}

${ }^{1}$ Tracer study site. Multiple samples collected on July 30, 2005. One exceedance for the day is shown on figure 13.

${ }^{2}$ Site location on figure 5 is approximated. Site location based on available latitude and longitude data did not plot near stream or water body.

${ }^{3}$ Existing quality: 85th percentile of the data. See Colorado Department of Public Health and Environment, 2008c, 2008d. 
Table 7. Comparison of percentage of stream-water samples with trace-element concentrations exceeding Colorado Department of Public Health and Environment in-stream waterquality standards for protection of aquatic life for the Snake River, upper Blue River, and Tenmile Creek subwatersheds and the lower Blue River watershed, Blue River watershed, Colorado, October 1995 through July 2006.

[No., number; ne, no exceedances]

\begin{tabular}{|c|c|c|c|c|}
\hline \multirow[t]{3}{*}{ Trace element } & \multicolumn{4}{|c|}{$\begin{array}{l}\text { Percentage of stream-water samples } \\
\text { with concentrations exceeding } \\
\text { in-stream water-quality standard } \\
\text { for protection of aquatic life }\end{array}$} \\
\hline & \multicolumn{3}{|c|}{ Subwatershed } & \multirow{2}{*}{$\begin{array}{c}\text { Watershed } \\
\text { Lower } \\
\text { Blue River }\end{array}$} \\
\hline & $\begin{array}{l}\text { Snake } \\
\text { River }\end{array}$ & $\begin{array}{c}\text { Upper } \\
\text { Blue River }\end{array}$ & $\begin{array}{c}\text { Tenmile } \\
\text { Creek }\end{array}$ & \\
\hline Cadmium, dissolved & 68 & 14 & 6.7 & 0.3 \\
\hline Chromium, dissolved & ne & 1.2 & ne & ne \\
\hline Copper, dissolved & 41 & 5.2 & ne & 1.5 \\
\hline Iron, total recoverable & 6.2 & 1.9 & 0.9 & 1.2 \\
\hline Lead, dissolved & 21 & 9.8 & 2.5 & 0.3 \\
\hline Manganese, dissolved & 7.1 & 2.0 & ne & ne \\
\hline Mercury, total & 1.2 & ne & ne & ne \\
\hline Nickel, dissolved & ne & 0.5 & ne & ne \\
\hline Selenium, dissolved & 5.3 & ne & ne & ne \\
\hline Silver, dissolved & 1.7 & 2.1 & ne & ne \\
\hline Zinc, dissolved & 70 & 23 & ne & 0.6 \\
\hline $\begin{array}{l}\text { All trace-element } \\
\text { samples collected }\end{array}$ & 64 & 35 & 4.9 & 3.8 \\
\hline
\end{tabular}

A total of 63 samples collected from 13 sites were analyzed for coliform bacteria (table 2). All samples for total coliform were collected at the Snake River inlet to Dillon Reservoir; the maximum count was 130 colonies per 100 milliliters (col/100 mL) (table 5). Fecal coliform in most (21 of 23) samples were less than the laboratory reporting level of $3 \mathrm{col} / 100 \mathrm{~mL}$. The maximum $E$. coli count of $56.3 \mathrm{col} / 100 \mathrm{~mL}$ was in a Soda Creek sample collected downstream from a wastewater treatment plant. All concentrations of $E$. coli were less than the CDPHE water-quality standard for recreation (Colorado Department of Public Health and Environment, 2008c, 2008d).

\section{Upper Blue River Subwatershed}

In the Blue River water-quality database, water-quality data for the Blue River subwatershed were available for 51 sites and 1,200 samples (table 2). Of these sites and samples, data on physical properties were available for 49 sites and 974 samples (table 2). Almost all water temperature values and dissolved-oxygen concentrations met CDPHE water-quality standards for the protection of aquatic life. Stream water temperatures measured at the time of sample collection ranged between -1 and $18.1^{\circ} \mathrm{C}$ (table 8 ). Only about 2 percent ( 8 of 453) of the temperature values measured at seven sites between October and May were greater than the CDPHE acute aquatic-life water-quality standard of $13.0^{\circ} \mathrm{C}$ for those months.
Seven of the eight values were measured at six sites between late April and the end of May 2000. Almost all (286 of 289) dissolved-oxygen concentrations were greater than or equal to $6.0 \mathrm{mg} / \mathrm{L}$, the minimum dissolved-oxygen concentration set by the CDPHE for aquatic-life protection. The three concentrations less than the standard were measured on August 25, 1997, at three sites on the Blue River.

Specific conductance values in the upper Blue River subwatershed ranged from 32 to $7,890 \mu \mathrm{S} / \mathrm{cm}$ (table 8 ). This latter specific conductance value, measured at French Gulch at Breckenridge (site 93), was extreme. The next highest specific conductance value measured at a site was $875 \mu \mathrm{S} / \mathrm{cm}$. Most specific conductance values measured in the upper Blue River subwatershed were less than or equal to $300 \mu \mathrm{S} / \mathrm{cm}$. Specific conductance values greater than $300 \mu \mathrm{S} / \mathrm{cm}$ were measured at four French Gulch sites and five nearby sites on the Blue River and its tributaries. The median specific conductance at most stream sites was less than or equal to $200 \mu \mathrm{S} / \mathrm{cm}$ (fig. 6). Median specific conductance values for two French Gulch sites (French Gulch above Gibson Gulch, site 90; French Gulch at Breckenridge, site 93) and for Illinois Gulch at Breckenridge Ice Rink (site 94) were greater than $200 \mu \mathrm{S} / \mathrm{cm}$ (fig. 6). A more detailed study of French Gulch at Breckenridge (site 93) is available in Spahr and others (2000).

Stream water $\mathrm{pH}$ in the upper Blue River subwatershed was generally less acidic than that in the Snake River subwatershed. Values of $\mathrm{pH}$ ranged between 5.8 and 9.2 (table 8). Six percent ( 35 of 585) of the samples from 10 sites in the upper Blue River subwatershed had $\mathrm{pH}$ values that were outside of the CDPHE standard of 6.5-9.0; all but two were less than 6.5. Median $\mathrm{pH}$ values were equal to or greater than 6.7 at all sites with six or more samples in the upper Blue River subwatershed (fig. 7). Values of $\mathrm{pH}$ in the mined areas of French Gulch were near neutral (7.0) even though sulfiderich rocks were mined. Carbonate-rich rocks in the mined areas add buffering capacity to the water, largely neutralizing the input of acidic drainage after trace elements have been dissolved (Bails, 1998; U.S. Environmental Protection Agency, 2008b). The ANC at 32 sites in the upper Blue River subwatershed ranged between 2 and $120 \mathrm{mg} / \mathrm{L}$. The median concentration at French Gulch at Breckenridge (site 93) near the Wellington-Oro mine site was $35 \mathrm{mg} / \mathrm{L}$, much higher than the median concentration of about $7 \mathrm{mg} / \mathrm{L}$ for mined areas in the Snake River subwatershed.

A total of 105 samples from 14 sites were used to classify water type. Almost 57 percent of the samples were collected from French Gulch at Breckenridge (site 93). Upstream from mines and mine waste along French Gulch and in the Blue River upstream from French Gulch, the water was mostly a calcium bicarbonate type (fig. 8). Water type in French Gulch downstream from mines and mine waste was calcium sulfate type, reflecting the weathering of sulfate-bearing minerals in mine tunnels and mine waste rock and the addition of calcium from rocks weathered by acidic water (Kimball and others, 1999). Downstream from French Gulch and its effects on the Blue River, water type was again mostly a calcium bicarbonate type. 


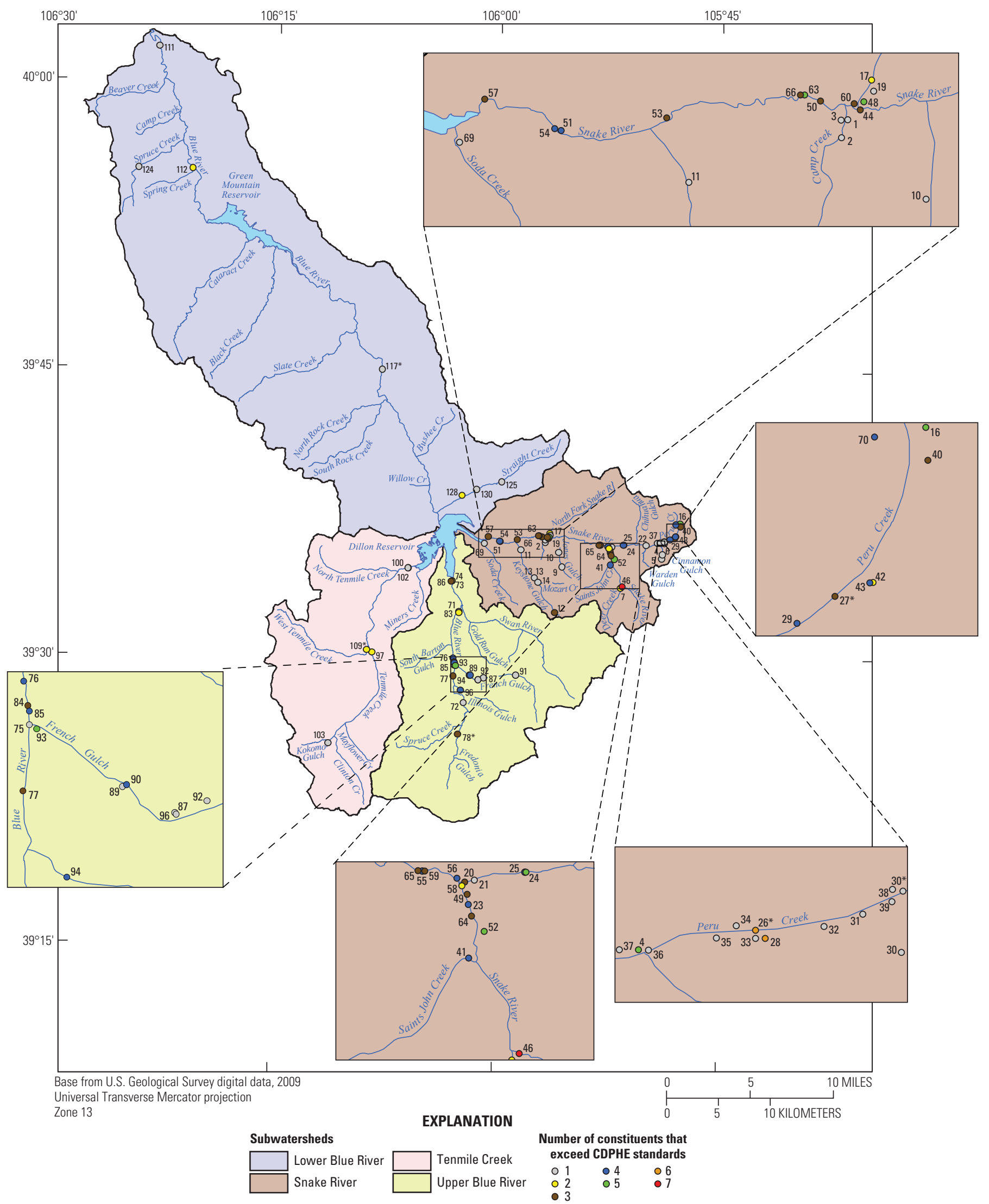

Figure 15. Spatial distribution of sites with trace-element concentrations that exceed Colorado Department of Public Health and Environment (CDPHE) trace-element water-quality standards for protection of aquatic life and number of constituents that are exceeded at a site, 1995 through 2006. Number next to symbol is site number, referenced in Appendix 1. The location of sites with an asterisk (for example, 109*) is approximated. 
Table 8. Summary of the number of samples and sites, minimum, median, and maximum values, and Colorado Department of Public Health and Environment in-stream waterquality standards for stream-water samples in the upper Blue River subwatershed, Blue River watershed, Colorado, 1995 through 2006.

[No., number; ${ }^{\circ} \mathrm{C}$, degrees Celsius; $\mathrm{mg} / \mathrm{L}$, milligrams per liter; $\mu \mathrm{S} / \mathrm{cm}$, microsiemens per centimeter at 25 degrees Celsius; --. no standard; $\mathrm{CaCO}_{3}$, calcium carbonate; $\mathrm{ft}^{3} / \mathrm{s}$, cubic feet per second; $\mathrm{HCO}_{3}^{-}$, bicarbonate; $<$, less than; DWS, domestic water supply; ne, no exceedance; N, nitrogen; TVS, table value standard; nc, not computed; P, phosphorus; $\mu \mathrm{g} / \mathrm{L}$, micrograms per liter; col/100 mL, colonies per $100 \mathrm{milliliters.} \mathrm{Water-}$ quality standards are from Colorado Department of Public Health and Environment (2008c, 2008d), unless otherwise noted; standards are for protection of aquatic life, unless otherwise stated. Standards may not apply to every site where data were collected. See table 6 for additional information on water-quality standards for trace elements]

\begin{tabular}{|c|c|c|c|c|c|c|c|c|}
\hline $\begin{array}{l}\text { Property or constituent } \\
\text { (reporting units) }\end{array}$ & $\begin{array}{l}\text { No. of } \\
\text { samples/ } \\
\text { no. of } \\
\text { censored } \\
\text { values }\end{array}$ & $\begin{array}{l}\text { No. of } \\
\text { sites }\end{array}$ & $\begin{array}{l}\text { Minimum } \\
\text { value }\end{array}$ & $\begin{array}{l}\text { Median } \\
\text { value }\end{array}$ & $\begin{array}{l}\text { Maximum } \\
\text { value }\end{array}$ & $\begin{array}{c}\text { In-stream } \\
\text { water-quality standard }\end{array}$ & $\begin{array}{c}\text { No. of sites with } \\
\text { measurement or } \\
\text { concentration greater than } \\
\text { censoring limit that do not } \\
\text { meet water-quality standard }\end{array}$ & $\begin{array}{l}\text { No. of samples with } \\
\text { measurement or } \\
\text { concentration greater than } \\
\text { censoring limit that do not } \\
\text { meet water-quality standard }\end{array}$ \\
\hline \multicolumn{9}{|c|}{ Physical properties } \\
\hline Water temperature $\left({ }^{\circ} \mathrm{C}\right)$ & $878 / 0$ & 45 & -1 & 7.3 & 18.1 & $\begin{array}{c}\text { June-September, } 21.2^{\circ} \mathrm{C} ;{ }^{1} \\
\text { October-May, } 13.0^{\circ} \mathrm{C}\end{array}$ & 7 (acute, October-May) & 8 (acute, October-May) \\
\hline Oxygen, dissolved (mg/L) & $289 / 0$ & 36 & 3.2 & 9.4 & 15.8 & 6.0 & 3 & 3 \\
\hline Specific conductance $(\mu \mathrm{S} / \mathrm{cm})$ & $721 / 0$ & 44 & 32 & 166 & 27,890 & -- & -- & -- \\
\hline $\mathrm{pH}$, field (standard units) & $585 / 0$ & 48 & 5.8 & 7.7 & 9.2 & $6.5-9.0$ & 10 & 35 \\
\hline $\begin{array}{l}\text { Acid neutralizing capacity } \\
\left(\mathrm{mg} / \mathrm{L} \text { as } \mathrm{CaCO}_{3}\right)\end{array}$ & $382 / 0$ & 32 & 2 & 42 & 120 & -- & -- & -- \\
\hline Discharge, annual mean $\left(\mathrm{ft}^{3} / \mathrm{s}\right)$ & ${ }^{3} 11 / 0$ & ${ }^{4} 1$ & 36.9 & 92.7 & 149.5 & -- & -- & -- \\
\hline \multicolumn{9}{|c|}{ Major ions } \\
\hline $\begin{array}{l}\text { Bicarbonate, dissolved } \\
\left(\mathrm{mg} / \mathrm{L} \text { as } \mathrm{HCO}_{3}^{-}\right)\end{array}$ & $219 / 0$ & 20 & 20 & 42 & 100 & -- & -- & -- \\
\hline Calcium, dissolved $(\mathrm{mg} / \mathrm{L})$ & $227 / 0$ & 25 & 11.0 & 24.0 & 62.5 & -- & -- & -- \\
\hline Chloride, dissolved (mg/L) & $115 / 6$ & 17 & $<0.1$ & 1.19 & 12.6 & ${ }^{5} 250$ DWS or none & ne & ne \\
\hline Chloride, total $(\mathrm{mg} / \mathrm{L})$ & $95 / 20$ & 16 & $<0.5$ & 1.49 & 23.0 & ${ }^{5} 250$ DWS or none & ne & ne \\
\hline Magnesium, dissolved (mg/L) & $227 / 0$ & 25 & 0.87 & 4.2 & 13.1 & -- & -- & -- \\
\hline Sulfate, dissolved $(\mathrm{mg} / \mathrm{L})$ & $315 / 6$ & 29 & $<4.6$ & 26 & 180 & ${ }^{5} 250$ DWS or none & ne & ne \\
\hline Sulfate, total $(\mathrm{mg} / \mathrm{L})$ & $6 / 0$ & 6 & 21 & 21.9 & 82.4 & ${ }^{5} 250$ DWS or none & ne & ne \\
\hline Dissolved solids (mg/L) & $301 / 0$ & 26 & 30 & 110 & 340 & ${ }^{6} 500$ & ne & ne \\
\hline Hardness $(\mathrm{mg} / \mathrm{L})$ & $352 / 0$ & 29 & 27 & 72 & 180 & -- & -- & -- \\
\hline \multicolumn{9}{|c|}{ Nutrients } \\
\hline Total ammonia (mg/L as N) & $262 / 202$ & 37 & $<0.001$ & 0.003 & 1.4 & TVS & ne & ne \\
\hline $\begin{array}{l}\text { Un-ionized ammonia } \\
\quad \text { (computed, } \mathrm{mg} / \mathrm{L} \text { as } \mathrm{N} \text { ) }\end{array}$ & $12 / 0$ & 3 & 0.0001 & $<0.001$ & 0.015 & -- & -- & -- \\
\hline Nitrite $(\mathrm{mg} / \mathrm{L}$ as N) & $142 / 132$ & 27 & $<0.002$ & $\mathrm{nc}^{7}$ & $<0.015$ & 0.05 & ne & ne \\
\hline Nitrate $(\mathrm{mg} / \mathrm{L}$ as $\mathrm{N})$ & 194/4 & 11 & $<0.0013$ & 0.101 & 1.0 & ${ }^{5} 10$ DWS, 100 & ne & ne \\
\hline Nitrogen, total (mg/L as N) & $43 / 0$ & 14 & 0.08 & 0.18 & 2.50 & -- & -- & -- \\
\hline Orthophosphate (mg/L as P) & $321 / 130$ & 32 & $<0.001$ & 0.010 & 0.020 & -- & -- & -- \\
\hline Phosphorus, total (mg/L as P) & $428 / 135$ & 30 & $<0.002$ & 0.010 & 0.520 & ${ }^{8} 0.05,0.1$ & 3 & 6 \\
\hline \multicolumn{9}{|c|}{ Trace elements } \\
\hline Aluminum, dissolved $(\mu \mathrm{g} / \mathrm{L})$ & $255 / 141$ & 26 & $<1$ & 8 & 150 & -- & -- & -- \\
\hline Arsenic, dissolved $(\mu \mathrm{g} / \mathrm{L})$ & $266 / 259$ & 28 & $<0.05$ & $\mathrm{nc}^{7}$ & $<6$ & 340 (acute) & ne & ne \\
\hline Arsenic, total recoverable $(\mu \mathrm{g} / \mathrm{L})$ & 9/9 & 9 & $<1$ & $\mathrm{nc}^{7}$ & $<6$ & ${ }^{5} 0.02,7.6,10.0$ (chronic) & ne & ne \\
\hline Cadmium, dissolved $(\mu \mathrm{g} / \mathrm{L})$ & $476 / 196$ & 33 & $<0.04$ & 0.66 & 20.1 & TVS $,{ }^{5,9} 4.0,{ }^{10} 8.17$ & 12 & 66 \\
\hline Chromium, dissolved $(\mu \mathrm{g} / \mathrm{L})$ & $167 / 131$ & 26 & $<0.2$ & 0.4 & 89 & TVS (16 acute, 11 chronic) & 1 & 2 \\
\hline Copper, dissolved $(\mu \mathrm{g} / \mathrm{L})$ & $402 / 201$ & 32 & $<0.7$ & 1.3 & 27.4 & TVS $^{9}$ & 7 & 21 \\
\hline Iron, dissolved $(\mu \mathrm{g} / \mathrm{L})$ & $437 / 226$ & 33 & $<0.05$ & 8.1 & 520 & ${ }^{5} 300$ DWS or no DWS & ne & ne \\
\hline
\end{tabular}


Table 8. Summary of the number of samples and sites, minimum, median, and maximum values, and Colorado Department of Public Health and Environment in-stream waterquality standards for stream-water samples in the upper Blue River subwatershed, Blue River watershed, Colorado, 1995 through 2006.-Continued

[No., number; ${ }^{\circ} \mathrm{C}$, degrees Celsius; mg/L, milligrams per liter; $\mu \mathrm{S} / \mathrm{cm}$, microsiemens per centimeter at 25 degrees Celsius; --. no standard; $\mathrm{CaCO}_{3}$, calcium carbonate; $\mathrm{ft}^{3} / \mathrm{s}$, cubic feet per second; $\mathrm{HCO}_{3}^{-}$, bicarbonate; $<$, less than; DWS, domestic water supply; ne, no exceedance; N, nitrogen; TVS, table value standard; nc, not computed; P, phosphorus; $\mu \mathrm{g} / \mathrm{L}$, micrograms per liter; col/100 mL, colonies per 100 milliliters. Waterquality standards are from Colorado Department of Public Health and Environment (2008c, 2008d), unless otherwise noted; standards are for protection of aquatic life, unless otherwise stated. Standards may not apply to every site where data were collected. See table 6 for additional information on water-quality standards for trace elements]

\begin{tabular}{|c|c|c|c|c|c|c|c|c|}
\hline $\begin{array}{l}\text { Property or constituent } \\
\text { (reporting units) }\end{array}$ & $\begin{array}{l}\text { No. of } \\
\text { samples/ } \\
\text { no. of } \\
\text { censored } \\
\text { values }\end{array}$ & $\begin{array}{c}\text { No. of } \\
\text { sites }\end{array}$ & $\begin{array}{l}\text { Minimum } \\
\text { value }\end{array}$ & $\begin{array}{l}\text { Median } \\
\text { value }\end{array}$ & $\begin{array}{l}\text { Maximum } \\
\text { value }\end{array}$ & $\begin{array}{c}\text { In-stream } \\
\text { water-quality standard }\end{array}$ & $\begin{array}{l}\text { No. of sites with } \\
\text { measurement or } \\
\text { concentration greater than } \\
\text { censoring limit that do not } \\
\text { meet water-quality standard }\end{array}$ & $\begin{array}{l}\text { No. of samples with } \\
\text { measurement or } \\
\text { concentration greater than } \\
\text { censoring limit that do not } \\
\text { meet water-quality standard }\end{array}$ \\
\hline \multicolumn{9}{|c|}{ Trace elements-Continued } \\
\hline Iron, total recoverable $(\mu \mathrm{g} / \mathrm{L})$ & $361 / 67$ & 35 & $<10$ & 69 & 8,251 & 1,000 (chronic) & 6 & 7 \\
\hline Lead, dissolved $(\mu \mathrm{g} / \mathrm{L})$ & $469 / 302$ & 33 & 0.1 & 0.4 & ${ }^{11}<50$ & TVS, $, 5,9105.0$ & 7 & 46 \\
\hline Manganese, dissolved ( $\mu \mathrm{g} / \mathrm{L})$ & $495 / 146$ & 34 & $<0.03$ & 11 & 4,590 & TVS, ${ }^{95} 50$ DWS or no DWS & 1 TVS, 4 DWS & 10 TVS, 20 DWS \\
\hline Mercury, total $(\mu \mathrm{g} / \mathrm{L})$ & $101 / 101$ & 6 & $<0.01$ & $\mathrm{nc}^{7}$ & $<0.2$ & 0.01 & ne & ne \\
\hline Nickel, dissolved $(\mu \mathrm{g} / \mathrm{L})$ & $189 / 119$ & 24 & $<1$ & 1.86 & 85 & TVS $^{9}$ & 1 & 1 \\
\hline Selenium, dissolved $(\mu \mathrm{g} / \mathrm{L})$ & $229 / 228$ & 23 & $<1$ & $\mathrm{nc}^{7}$ & $<12$ & TVS (18.4 acute, 4.6 chronic) & ne & ne \\
\hline Silver, dissolved $(\mu \mathrm{g} / \mathrm{L})$ & $240 / 235$ & 27 & $<0.02$ & $\mathrm{nc}^{7}$ & 5.5 & TVS $^{9}$ & 1 & 5 \\
\hline Uranium, natural, dissolved $(\mu \mathrm{g} / \mathrm{L})$ & $111 / 108$ & 16 & $<1$ & $\mathrm{nc}^{7}$ & 3 & 1230 & ne & ne \\
\hline Zinc, dissolved $(\mu \mathrm{g} / \mathrm{L})$ & $449 / 67$ & 36 & $<1$ & 117 & 15,500 & TVS, $, 5,9104,137$ & 14 & 104 \\
\hline \multicolumn{9}{|c|}{ Suspended sediment } \\
\hline Suspended sediment (mg/L) & $187 / 0$ & 15 & 0 & 2 & 287 & -- & -- & -- \\
\hline \multicolumn{9}{|c|}{ Coliform bacteria } \\
\hline Total coliform (col/100 mL) & $13 / 2$ & 3 & 9 & 66 & ${ }^{13} 228$ & -- & -- & -- \\
\hline Fecal coliform (col/100 mL) & $14 / 10$ & 2 & $<3$ & $<3$ & 9 & -- & -- & -- \\
\hline Escherichia coli $(\mathrm{col} / 100 \mathrm{~mL})$ & $54 / 0$ & 5 & 0 & 1 & 41.3 & ${ }^{5,14} 126,205$ & ne & ne \\
\hline
\end{tabular}

${ }^{1}$ Acute temperature standard (Colorado Department of Public Health and Environment, 2008c).

${ }^{2}$ Extreme value. Next highest value was $875 \mu \mathrm{S} / \mathrm{cm}$.

${ }^{3}$ Water years 1996-2006. A water year is a 12-month period beginning October 1 and ending September 30 of the following year. A water year is designated as the year in which it ends

${ }^{4}$ Blue River near Dillon, CO (USGS site number 09046600)

${ }^{5}$ Standard varies by stream segment. See Colorado Department of Public Health and Environment (2008d).

${ }^{6}$ USEPA secondary drinking-water standard, nonenforceable guideline. See U.S. Environmental Protection Agency (2008a)

${ }^{7}$ Eighty percent or more of data were censored values. Median value could not be computed.

${ }^{8}$ USEPA-recommended concentration limits for total phosphorus to control eutrophication in downstream water bodies; $0.05 \mathrm{mg} / \mathrm{L}$ is for streams that flow directly into lakes and reservoirs, $0.1 \mathrm{mg} / \mathrm{L}$ is for streams that do not flow directly into lakes and reservoirs (U.S. Environmental Protection Agency, 1986).

${ }^{9}$ Standard varies with hardness. See Colorado Department of Public Health and Environment (2008c).

${ }^{10}$ Existing quality: 85th percentile of the data. See Colorado Department of Public Health and Environment (2008c).

${ }^{11}$ Maximum value does not include four values censored at greater than $40 \mu \mathrm{g} / \mathrm{L}$ and one value censored at greater than $50 \mu \mathrm{g} / \mathrm{L}$.

${ }^{12}$ USEPA primary drinking-water standard, enforceable guideline. See U.S. Environmental Protection Agency (2008a)

${ }^{13}$ Maximum value does not include one value censored at greater than $200 \mathrm{col} / 100 \mathrm{~mL}$ and one value censored at greater than $201 \mathrm{col} / 100 \mathrm{~mL}$.

${ }^{14}$ Standard applies to recreational use 
Major-ion and total dissolved-solids concentrations and hardness values were lower during snowmelt runoff than during low streamflow. All chloride and sulfate concentrations in the upper Blue River subwatershed were less than $250 \mathrm{mg} / \mathrm{L}$, the CDPHE domestic water-supply standard for each constituent (table 8). Sulfate concentrations varied spatially with the presence or absence of historical mining and sulfate-bearing minerals. At sites on the Blue River and French Gulch upstream from the effects of mining and weathering of sulfate-bearing minerals, dissolved sulfate concentrations generally were less than or equal to $20 \mathrm{mg} / \mathrm{L}$; whereas, at the mining-affected site French Gulch at Breckenridge (site 93), the median dissolved sulfate concentration was $78.1 \mathrm{mg} / \mathrm{L}$. All dissolved-solids concentrations were less than the USEPArecommended concentration of $500 \mathrm{mg} / \mathrm{L}$ (U.S. Environmental Protection Agency, 2008a). Maximum hardness values were less than or equal to $100 \mathrm{mg} / \mathrm{L}$ at most sites in the upper Blue River subwatershed. Sites with maximum hardness values greater than $100 \mathrm{mg} / \mathrm{L}$ were generally located in or near French Gulch. These sites typically had higher calcium concentrations than other sites in the upper Blue River subwatershed.

A total of 485 samples were collected for nutrient analysis at 38 sites in the upper Blue River subwatershed (table 2). More than 67 percent of the samples were collected at four sites: Blue River near Dillon, CO (site 86), Blue River at Blue River (site 79), French Gulch at Breckenridge (site 93), and Blue River above Dillon Reservoir (site 74). Total phosphorus samples were collected more often than other nutrients. Data for some nutrients at the Blue River just upstream from Dillon Reservoir have been collected since 1979.

Concentrations of total ammonia, un-ionized ammonia, nitrite, and nitrate were low at all sites in the upper Blue River subwatershed (table 8). Most (77 percent) total ammonia data were censored. All total ammonia concentrations were less than the CDPHE acute and chronic TVSs adopted for the protection of aquatic life. Un-ionized ammonia concentrations in 12 samples collected during 1996 and 1997 were less than or equal to $0.015 \mathrm{mg} / \mathrm{L}$. Almost all (93 percent) nitrite data were censored. Detected concentrations were less than $0.015 \mathrm{mg} / \mathrm{L}$ and much lower than the CDPHE water-quality standard of $0.05 \mathrm{mg} / \mathrm{L}$ for protection of aquatic life. The maximum nitrate concentration for sites in the upper Blue River subwatershed was $1.0 \mathrm{mg} / \mathrm{L}$, much lower than the CDPHE drinking-water standard of $10 \mathrm{mg} / \mathrm{L}$. All concentrations greater than or equal to $0.3 \mathrm{mg} / \mathrm{L}$ were in samples collected at Blue River near Dillon, CO (site 86), just upstream from the inlet to Dillon Reservoir; 18 of the 19 samples have been collected since 2000. Median nitrate concentrations for the four sites in the upper Blue River subwatershed with six or more nitrate samples were less than or equal to $0.20 \mathrm{mg} / \mathrm{L}$ (fig. 9).

Orthophosphate concentrations were less than or equal to $0.020 \mathrm{mg} / \mathrm{L}$ (table 8 ). Almost 40 percent of the data were censored. Most (98 percent) total phosphorus concentrations were $0.05 \mathrm{mg} / \mathrm{L}$ or less, and almost one-third of the data were censored. The median concentration of 0.010 was less than the median concentration of $0.020 \mathrm{mg} / \mathrm{L}$ for total phosphorus for rivers and streams in the southern Rocky Mountains (U.S. Environmental Protection Agency, 2000a). Median total phosphorus concentrations at the six sites with six or more samples were less than $0.05 \mathrm{mg} / \mathrm{L}$ (fig. 10). The USEPA-recommended total phosphorus concentration limit of $0.05 \mathrm{mg} / \mathrm{L}$ for streams that directly flow into reservoirs was exceeded in less than 4 percent (6 of 160) of samples collected at three Blue River sites just upstream from Dillon Reservoir; the six samples were collected prior to July 2001. For streams that do not directly flow into Dillon Reservoir, all concentrations were less than $0.1 \mathrm{mg} / \mathrm{L}$.

Trace-element data were available for 552 samples collected at 40 sites in the upper Blue River subwatershed (table 2). Concentrations reflected the occurrence or absence of mining activities and acidic mine drainage in a sampling area. Oxidation of sulfide minerals in mine tunnels, adits, and other structures has likely caused increased concentrations of some trace elements, especially iron, cadmium, manganese, and zinc, in some stream segments in the upper Blue River subwatershed.

Concentrations of many trace elements including dissolved arsenic, selenium, and uranium and total mercury generally were low throughout the subwatershed (table 8). Some concentration of dissolved aluminum and lead were censored at laboratory reporting levels as great as $50 \mu \mathrm{g} / \mathrm{L}$. Concentrations of dissolved cadmium, manganese, and zinc and dissolved and total recoverable iron were high in mined areas of French Gulch and downstream sites on French Gulch and the Blue River, and in Illinois Gulch. Metals in French Gulch originate from mine drainage at the Wellington-Oro mine complex and enter the stream through groundwater from a natural seep, the intersection of a fault system with the stream, and surface drainage from the fault (Kimball and others, 1999; U.S. Environmental Protection Agency, 2008b). Concentrations of dissolved iron were as high as $520 \mu \mathrm{g} / \mathrm{L}$ at French Gulch above Gibson Gulch (site 90) but were more variable than other metals because of precipitation from solution (Kimball and others, 1999). As discussed in the Snake River subwatershed section, iron precipitates out of solution where streams with acidic drainage and streams with higher $\mathrm{pH}$ merge; cadmium and zinc remain in solution. Concentrations of iron also were elevated near the headwaters of the Blue River, an area not affected by historical mining that has low concentrations of cadmium, manganese, and zinc. Median concentrations of dissolved and total recoverable iron were 16 and $54 \mu \mathrm{g} / \mathrm{L}$, respectively, at Blue River above town of Blue River (site 78). Iron concentrations, especially total recoverable iron, remained elevated at sites in the downstream segments of the Blue River.

The spatial distribution of median concentrations of dissolved cadmium, copper, manganese, and zinc for sites with six or more samples in the upper Blue River subwatershed are illustrated in figures 11-14. The median dissolved cadmium 
concentration was equal to or greater than $7.0 \mu \mathrm{g} / \mathrm{L}$ at two mining-affected sites, French Gulch above Gibson Gulch (site 90) and French Gulch at Breckenridge (site 93), and less than $1 \mu \mathrm{g} / \mathrm{L}$ at sites upstream and the farthest downstream from abandoned mines, French Gulch above Wellington Mine (site 92) and Blue River above Dillon Reservoir (site 74), respectively. Concentrations of dissolved manganese were elevated at French Gulch above Gibson Gulch (site 90, median concentration 2,890 $\mu \mathrm{g} / \mathrm{L}$ ) and Illinois Gulch (site 94, median concentration $130 \mu \mathrm{g} / \mathrm{L})$. Both sites are affected by mine drainage. Concentrations of dissolved manganese downstream from these sites decreased to a maximum median concentration of $37 \mu \mathrm{g} / \mathrm{L}$ and a minimum median concentration of less than $4 \mu \mathrm{g} / \mathrm{L}$. Median dissolved zinc concentrations ranged from less than $1 \mu \mathrm{g} / \mathrm{L}$ in the headwaters area of the Blue River to $20 \mu \mathrm{g} / \mathrm{L}$ upstream from mining areas on French Gulch to $10,700 \mu \mathrm{g} / \mathrm{L}$ at French Gulch above Gibson Gulch (site 90). The median zinc concentration decreased downstream and was $25 \mu \mathrm{g} / \mathrm{L}$ at Blue River above Dillon Reservoir (site 74). Median concentrations of dissolved manganese and zinc remained elevated at sites on the Blue River downstream from the confluence with French Gulch to the inlet at Dillon Reservoir.

Concentrations of dissolved cadmium, chromium, copper, lead, manganese, nickel, silver, and zinc and total recoverable iron exceeded CDPHE aquatic-life water-quality standards in 184 samples collected at 21 sites on the Blue River, French Gulch, and Illinois Gulch (fig. 15, table 6). Exceedances occurred at about 52 percent of the sites sampled for trace elements and in about 35 percent of samples collected. The standard for zinc was exceeded at the most sites (14), followed by cadmium (12 sites) and copper and lead (7 sites each). Standards for zinc and cadmium were exceeded in the most samples, 23 and 14 percent, respectively, followed by lead ( 9.8 percent) and copper (5.2 percent) (table 7$)$. The maximum number of aquatic-life standards exceeded was five, at French Gulch at Breckenridge (site 93). Water-quality standards for aquatic-life protection were exceeded most frequently at mining sites and sites downstream from historical mining that were affected by mine drainage, especially French Gulch, the Blue River downstream from the confluence with French Gulch, and Illinois Gulch. A new water treatment plant opened on French Gulch in November 2008 to remove cadmium and zinc from entering French Gulch at the Wellington-Oro mine site. Illinois Gulch is on the State of Colorado 2008 303(d) list of impaired waters for nonattainment of the aquatic-life use standard for dissolved zinc (Colorado Department of Public Health and Environment, 2008a). Two streams, Gold Run Gulch below Jessie Mine and South Branch Swan River below Royal Tiger Mine, are on the State of Colorado 2008 Monitoring and Evaluation list for zinc; Gold Run Gulch also is listed for cadmium (Colorado Department of Public Health and Environment, 2008a). Cleanup efforts have occurred at these sites since the listing (Town of Breckenridge, 2008). Laboratory reporting levels for total mercury were greater than the standard for aquatic-life protection. The CDPHE domestic water-supply standard for manganese was exceeded at four sites.

The effects of trace-element toxicity on aquatic biota in the upper Blue River subwatershed was observed by the CDPHE in the late 1980s with the mortality of newly released fingerlings in the Blue River downstream from French Gulch and others in the 1990s. Fish were not present in French Gulch downstream from the mined area to the mouth of the stream in 1995 and 1996 (Deacon and Mize, 1997; Deacon and Stephens, 1998). Cadmium and zinc were elevated in brown trout at Blue River near Breckenridge (site 85), downstream from French Gulch (Deacon and Stephens, 1998). A decrease in the abundance of macroinvertebrates at French Gulch at Breckenridge (site 93) was because of the effects of elevated trace-element concentrations (Deacon and others, 2001). Zinc from mine drainage is the primary cause of traceelement toxicity to fish and other aquatic life in French Gulch (Kimball and others, 1999; U.S. Environmental Protection Agency, 2008b).

A total of 187 samples collected from 15 sites in the upper Blue River subwatershed were analyzed for suspended-sediment concentration (tables 3 and 8). Most (141 of 187) samples were collected at two sites: French Gulch at Breckenridge (site 93, 96 samples) and Blue River near Dillon (site 86, 45 samples). For the French Gulch site, sampled between November 1995 and April 1999, maximum suspended-sediment concentrations (20-65 mg/L) occurred in March. For the Blue River site, sampled between April 1996 and September 1998, maximum concentrations (47-139 mg/L) tended to occur in late April through June.

A total of 79 samples collected from seven sites were analyzed for coliform bacteria (table 2). Bacteria were detected in 46 samples. The maximum count of total coliform was $228 \mathrm{col} / 100 \mathrm{~mL}$ (table 8 ). Fecal coliform concentrations in most (10 of 14) samples were less than the laboratory reporting level of $3 \mathrm{col} / 100 \mathrm{~mL}$. All concentrations of $E$. coli were less than the CDPHE in-stream water-quality standard for recreation (Colorado Department of Public Health and Environment, 2008c, 2008d).

\section{Tenmile Creek Subwatershed}

In the Blue River water-quality database, water-quality data for the Tenmile Creek subwatershed were available for 19 sites and 459 samples (table 2). Of these sites and samples, data on physical properties were available for all 19 sites and 358 samples (table 2). Water temperatures measured at the time of sample collection ranged between -1 and $22.9^{\circ} \mathrm{C}$. Only the latter value was greater than the water-quality standard for cold-water aquatic life, specifically the June through September standard (table 9). Most (88 of 96) dissolvedoxygen concentrations were greater than the minimum CDPHE standard of $6.0 \mathrm{mg} / \mathrm{L}$ for protection of aquatic life. Values less than $6.0 \mathrm{mg} / \mathrm{L}$ were measured during June, July, and August. 
At least one specific conductance measurement was made at 17 sites in the Tenmile Creek subwatershed (table 9); values ranged from 40 to $2,140 \mu \mathrm{S} / \mathrm{cm}$ (table 9). Median specific conductance values for two West Tenmile Creek with six or more samples was less than $200 \mu \mathrm{S} / \mathrm{cm}$ (fig. 6). Median values for similar sites on Tenmile Creek were greater than $300 \mu \mathrm{S} / \mathrm{cm}$; the highest median value $(1,055 \mu \mathrm{S} / \mathrm{cm})$ was for Ten Mile Creek above Wheeler Junction (site 97) upstream from the confluence with West Tenmile Creek. Tenmile Creek and its tributaries upstream from the confluence are underlain by an extensive (greater than 8,000 feet thick) section of sedimentary rocks of the Pennsylvanian-Permian Maroon Formation and Pennsylvanian Minturn Formation (Widmann and others, 2004). These sedimentary rocks likely weather more readily than PreCambrian rocks that underlie other parts of the watershed. For this reason, water in Tenmile Creek has high concentrations of dissolved solids and high specific conductance values.

Almost all (104 of 106) pH values in the Tenmile Creek subwatershed were within the CDPHE standard of 6.5-9.0 (table 9). One value was less than 6.5 and one was greater than 9.0. Most $\mathrm{pH}$ measurements were made at Tenmile Creek sites near Dillon Reservoir or at West Tenmile Creek sites. In the headwaters of Tenmile Creek, where the Kokomo and Climax mines are located (fig. 1), median $\mathrm{pH}$ for five samples from two sites was 7.7. Any acidic drainage that might occur from historical mining likely is limited because of neutralization by water from limestone beds in the Minturn Formation, treatment of affected water with lime, and diversion of clean water around mining-affected areas (Northwest Colorado Council of Governments, 2012; GlobalInfoMine, 2008). All median $\mathrm{pH}$ values in the Tenmile Creek subwatershed were greater than or equal to 7.5 (fig. 7). The ANC at sites in the Tenmile Creek subwatershed ranged between 1 and $112 \mathrm{mg} / \mathrm{L}$ and the median concentration was $40 \mathrm{mg} / \mathrm{L}$.

Type of water only could be determined for nine samples at two sites in the Tenmile Creek subwatershed: Tenmile Creek below North Tenmile Creek (site 104, one sample) and Tenmile Creek at 4th Street at Frisco (site 100, eight samples). Both sites had calcium sulfate type water.

All samples for chloride had concentrations less than the CDPHE domestic water-supply standard of $250 \mathrm{mg} / \mathrm{L}$ (table 9). The CDPHE domestic water-supply standard for sulfate, also $250 \mathrm{mg} / \mathrm{L}$, was exceeded in 8 percent (4 of 50) of dissolved samples collected at 2 of 7 sites in stream reaches for which the standard is applicable. Sites with exceedances were Tenmile Creek at 4th Street at Frisco (site 100, 1 sample) and Tenmile Creek at Frisco (site 101, 3 samples) The highest dissolved sulfate concentrations, those greater than $500 \mathrm{mg} / \mathrm{L}$, mostly were measured at the site Ten Mile Creek above Wheeler Junction (site 97), which is exempt from the standard. The USEPA-recommended dissolved-solids concentration of $500 \mathrm{mg} / \mathrm{L}$ was exceeded in 28 percent ( 22 of 78) of the samples. All exceedances were at Tenmile Creek sites. Hardness values in Tenmile Creek also were higher than in other streams in the subwatershed. The median hardness was
$272 \mathrm{mg} / \mathrm{L}$ at sites on Tenmile Creek and $84 \mathrm{mg} / \mathrm{L}$ at other sites in the Tenmile Creek subwatershed. Elevated hardness in some municipal groundwater wells located along Tenmile Creek in the alluvium can negatively affect dishwashing in restaurants and other industrial uses in Frisco (Dave Koop, Frisco Water Department, oral commun., 2008). For sites along Tenmile Creek, the hardness values were higher during low streamflows than during snowmelt runoff. The higher concentrations of dissolved constituents in Tenmile Creek low flows most likely result from inflow of groundwater high in dissolved constituents. Groundwater likely gains dissolved constituents as it flows through the sedimentary rocks of the Minturn and Maroon Formations upstream from the confluence with West Tenmile Creek and sulfide minerals in the orebodies of the Climax and Kokomo mining areas.

A total of 284 water samples were collected for nutrient analysis at 13 sites in the Tenmile Creek subwatershed (table 2). Samples were collected from Tenmile Creek, West Tenmile Creek, and Clinton Creek-most commonly from Tenmile Creek at Frisco (site 101, 108 samples) and Tenmile Creek below North Tenmile Creek (site 104, 71 samples). Total phosphorus samples were collected most often and at all sampled sites, followed by nitrate.

Most concentrations of total ammonia, un-ionized ammonia, nitrate, orthophosphate, and total phosphorus in samples were low (table 9). Total ammonia concentrations were less than the computed CDPHE acute and chronic TVSs, which ranged from 0.72 to $38 \mathrm{mg} / \mathrm{L}$ for the acute standard and 0.30 to $7.0 \mathrm{mg} / \mathrm{L}$ for the chronic standard (Colorado Department of Public Health and Environment, 2008d). More than half of the total ammonia concentrations in samples were censored values (table 9). All 19 samples for un-ionized ammonia were collected in 1997; only one concentration was greater than $0.015 \mathrm{mg} / \mathrm{L}$. The maximum nitrate concentration of $0.605 \mathrm{mg} / \mathrm{L}$ was well below the domestic water-supply standard of $10 \mathrm{mg} / \mathrm{L}$. Only two sites in the Tenmile Creek subwatershed had six or more nitrate samples, both in the most downstream portion of the subwatershed. Median nitrate concentrations for these two sites were low, less than $0.50 \mathrm{mg} / \mathrm{L}$ (fig. 9). Total nitrogen data only were available for 13 samples. The maximum concentration was $1.43 \mathrm{mg} / \mathrm{L}$.

Orthophosphate concentrations were less than or equal to $0.021 \mathrm{mg} / \mathrm{L}$ (table 9). Most (93 percent) total phosphorus concentrations were less than $0.05 \mathrm{mg} / \mathrm{L}$. About 16 percent of the total phosphorus data were censored values. The median concentration of 0.008 was less than the median concentration of $0.020 \mathrm{mg} / \mathrm{L}$ for total phosphorus for rivers and streams in the southern Rocky Mountains (U.S. Environmental Protection Agency, 2000a). Sites with six or more total phosphorus samples were distributed throughout the subwatershed; median concentrations were less than or equal to $0.04 \mathrm{mg} / \mathrm{L}$ (fig. 10). For streams that directly flow into reservoirs, the USEPArecommended total phosphorus concentration of $0.05 \mathrm{mg} / \mathrm{L}$ was not exceeded (fig. 10). For streams that do not directly flow into reservoirs, the recommended limit of $0.1 \mathrm{mg} / \mathrm{L}$ was exceeded in five samples, four from West Tenmile Creek and 
Table 9. Summary of the number of samples and sites, minimum, median, and maximum values, and Colorado Department of Public Health and Environment in-stream waterquality standards for stream-water samples in the Tenmile Creek subwatershed, Blue River watershed, Colorado, 1995 through 2006.

[No., number; ${ }^{\circ} \mathrm{C}$, degrees Celsius; $\mathrm{mg} / \mathrm{L}$, milligrams per liter; $\mu \mathrm{S} / \mathrm{cm}$, microsiemens per centimeter at 25 degrees Celsius; --. no standard; $\mathrm{CaCO}_{3}$, calcium carbonate; $\mathrm{ft}^{3} / \mathrm{s}$, cubic feet per second; $\mathrm{HCO}_{3}^{-}$, bicarbonate; DWS, domestic water supply; ne, no exceedance; <, less than; N, nitrogen; TVS, table value standard; P, phosphorus; $\mu \mathrm{g} / \mathrm{L}$, micrograms per liter; nc, not computed; col/100 mL, colonies per 100 milliliters. Waterquality standards are from Colorado Department of Public Health and Environment (2008c, 2008d) unless otherwise noted; standards are for protection of aquatic life unless otherwise stated. Standards may not apply to every site where data were collected. See table 6 for additional information on water-quality standards for trace elements]

\begin{tabular}{|c|c|c|c|c|c|c|c|c|}
\hline $\begin{array}{l}\text { Property or constituent } \\
\text { (reporting units) }\end{array}$ & $\begin{array}{l}\text { No. of } \\
\text { samples/ } \\
\text { no. of } \\
\text { censored } \\
\text { values }\end{array}$ & $\begin{array}{l}\text { No. of } \\
\text { sites }\end{array}$ & $\begin{array}{l}\text { Minimum } \\
\text { value }\end{array}$ & $\begin{array}{l}\text { Median } \\
\text { value }\end{array}$ & $\begin{array}{l}\text { Maximum } \\
\text { value }\end{array}$ & $\begin{array}{l}\text { In-stream } \\
\text { water-quality standard }\end{array}$ & $\begin{array}{l}\text { No. of sites with } \\
\text { measurement or } \\
\text { concentration greater than } \\
\text { censoring limit that do not } \\
\text { meet water-quality standard }\end{array}$ & $\begin{array}{l}\text { No. of samples with } \\
\text { measurement or } \\
\text { concentration greater than } \\
\text { censoring limit that do not } \\
\text { meet water-quality standard }\end{array}$ \\
\hline \multicolumn{9}{|c|}{ Physical properties } \\
\hline Temperature $\left({ }^{\circ} \mathrm{C}\right)$ & $305 / 0$ & 17 & -1 & 5.6 & 22.9 & $\begin{array}{c}{ }^{1} \mathrm{June}-\text { September, } 21.2^{\circ} \mathrm{C} ; \\
\text { October-May, } 13.0^{\circ} \mathrm{C}\end{array}$ & 1 (acute, June-September) & 1 (acute, June-September) \\
\hline Oxygen, dissolved (mg/L) & $96 / 0$ & 11 & 1.9 & 8.8 & 14.2 & 6.0 & 6 & 8 \\
\hline Specific conductance $(\mu \mathrm{S} / \mathrm{cm})$ & $261 / 0$ & 17 & 40 & 515 & 2,140 & -- & -- & -- \\
\hline $\mathrm{pH}$, field (standard units) & $106 / 0$ & 11 & 5.4 & 7.8 & 9.1 & $6.5-9.0$ & 2 & 2 \\
\hline $\begin{array}{l}\text { Acid neutralizing capacity } \\
\qquad\left(\mathrm{mg} / \mathrm{L} \text { as } \mathrm{CaCO}_{3}\right)\end{array}$ & $59 / 0$ & 9 & 1 & 40 & 112 & -- & -- & -- \\
\hline Discharge, annual mean $\left(\mathrm{ft}^{3} / \mathrm{s}\right)$ & $211 / 0$ & ${ }^{3} 1$ & 48.0 & 101.8 & 147.3 & -- & -- & -- \\
\hline \multicolumn{9}{|c|}{ Major ions } \\
\hline $\begin{array}{l}\text { Bicarbonate, dissolved } \\
\left(\mathrm{mg} / \mathrm{L} \text { as } \mathrm{HCO}_{3}^{-}\right)\end{array}$ & $10 / 0$ & 2 & 32 & 52 & 55 & -- & -- & -- \\
\hline Calcium, dissolved $(\mathrm{mg} / \mathrm{L})$ & $37 / 0$ & 5 & 10.1 & 44.9 & 267 & -- & -- & -- \\
\hline Chloride, dissolved (mg/L) & $39 / 0$ & 6 & 1.74 & 7 & 59 & ${ }^{4} 250$ DWS or none & ne & ne \\
\hline Chloride, total $(\mathrm{mg} / \mathrm{L})$ & $2 / 0$ & 1 & 5 & 5 & 5 & ${ }^{4} 250$ DWS or none & ne & ne \\
\hline Magnesium, dissolved (mg/L) & $39 / 0$ & 7 & 0.9 & 3.8 & 13 & - & -- & -- \\
\hline Sulfate, dissolved $(\mathrm{mg} / \mathrm{L})$ & $80 / 12$ & 9 & $<5$ & 106 & 1,100 & ${ }^{4} 250$ DWS or none & 2 & 4 \\
\hline Sulfate, total $(\mathrm{mg} / \mathrm{L})$ & $21 / 15$ & 1 & $<10$ & $<10$ & 10 & ${ }^{4} 250$ DWS or none & ne & ne \\
\hline Dissolved solids (mg/L) & $78 / 0$ & 9 & 41 & 229 & 1,650 & 5500 & 4 & 22 \\
\hline Hardness $(\mathrm{mg} / \mathrm{L})$ & $111 / 0$ & 11 & 31 & 180 & 1,100 & -- & -- & - \\
\hline \multicolumn{9}{|c|}{ Nutrients } \\
\hline Total ammonia (mg/L as N) & $107 / 61$ & 9 & $<0.01$ & 0.041 & 0.89 & TVS & ne & ne \\
\hline $\begin{array}{l}\text { Un-ionized ammonia } \\
\quad \text { (computed, } \mathrm{mg} / \mathrm{L} \text { as } \mathrm{N})\end{array}$ & $19 / 0$ & 5 & 0.0001 & 0.001 & 0.044 & -- & -- & -- \\
\hline Nitrate $(\mathrm{mg} / \mathrm{L}$ as $\mathrm{N})$ & $140 / 0$ & 2 & 0.010 & 0.236 & 0.605 & ${ }^{4} 10$ DWS or none & ne & ne \\
\hline Nitrogen, total (mg/L as N) & $13 / 0$ & 2 & 0.25 & 0.71 & 1.43 & -- & -- & -- \\
\hline Orthophosphate (mg/L as $\mathrm{P}$ ) & $137 / 10$ & 2 & $<0.0001$ & 0.001 & 0.021 & -- & -- & -- \\
\hline Phosphorus, total (mg/L as P) & $263 / 43$ & 13 & $<0.002$ & 0.008 & 0.19 & ${ }^{6} 0.05,0.1$ & 3 & 5 \\
\hline
\end{tabular}


Table 9. Summary of the number of samples and sites, minimum, median, and maximum values, and Colorado Department of Public Health and Environment in-stream waterquality standards for stream-water samples in the Tenmile Creek subwatershed, Blue River watershed, Colorado, 1995 through 2006.-Continued

[No., number; ${ }^{\circ} \mathrm{C}$, degrees Celsius; $\mathrm{mg} / \mathrm{L}$, milligrams per liter; $\mu \mathrm{S} / \mathrm{cm}$, microsiemens per centimeter at 25 degrees Celsius; --. no standard; $\mathrm{CaCO}_{3}$, calcium carbonate; $\mathrm{ft}^{3} / \mathrm{s}$, cubic feet per second; $\mathrm{HCO}_{3}^{-}$, bicarbonate; DWS, domestic water supply; ne, no exceedance; <, less than; N, nitrogen; TVS, table value standard; P, phosphorus; $\mu \mathrm{g} / \mathrm{L}$, micrograms per liter; nc, not computed; col/100 mL, colonies per $100 \mathrm{milliliters.} \mathrm{Water-}$ quality standards are from Colorado Department of Public Health and Environment (2008c, 2008d) unless otherwise noted; standards are for protection of aquatic life unless otherwise stated. Standards may not apply to every site where data were collected. See table 6 for additional information on water-quality standards for trace elements]

\begin{tabular}{|c|c|c|c|c|c|c|c|c|}
\hline $\begin{array}{l}\text { Property or constituent } \\
\text { (reporting units) }\end{array}$ & $\begin{array}{l}\text { No. of } \\
\text { samples/ } \\
\text { no. of } \\
\text { censored } \\
\text { values }\end{array}$ & $\begin{array}{l}\text { No. of } \\
\text { sites }\end{array}$ & $\begin{array}{l}\text { Minimum } \\
\text { value }\end{array}$ & $\begin{array}{l}\text { Median } \\
\text { value }\end{array}$ & $\begin{array}{l}\text { Maximum } \\
\text { value }\end{array}$ & $\begin{array}{l}\text { In-stream } \\
\text { water-quality standard }\end{array}$ & $\begin{array}{l}\text { No. of sites with } \\
\text { measurement or } \\
\text { concentration greater than } \\
\text { censoring limit that do not } \\
\text { meet water-quality standard }\end{array}$ & $\begin{array}{c}\text { No. of samples with } \\
\text { measurement or } \\
\text { concentration greater than } \\
\text { censoring limit that do not } \\
\text { meet water-quality standard }\end{array}$ \\
\hline \multicolumn{9}{|c|}{ 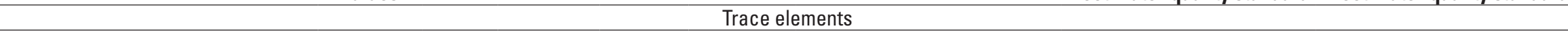 } \\
\hline Aluminum, dissolved $(\mu \mathrm{g} / \mathrm{L})$ & $66 / 38$ & 9 & $<24$ & 41 & 260 & -- & -- & -- \\
\hline Arsenic, dissolved $(\mu \mathrm{g} / \mathrm{L})$ & $72 / 72$ & 12 & $<1$ & $\mathrm{nc}^{7}$ & $<2$ & 340 (acute) & ne & ne \\
\hline Arsenic, total recoverable $(\mu \mathrm{g} / \mathrm{L})$ & $2 / 2$ & 2 & $<1$ & $\mathrm{nc}^{7}$ & $<1$ & ${ }^{4} 0.02,7.6$ (chronic) & ne & ne \\
\hline Cadmium, dissolved $(\mu \mathrm{g} / \mathrm{L})$ & $89 / 62$ & 10 & $<0.25$ & $<0.5$ & 2.1 & TVS $^{8}$ & 4 & 6 \\
\hline Chromium, dissolved $(\mu \mathrm{g} / \mathrm{L})$ & $11 / 11$ & 3 & $<1$ & $\mathrm{nc}^{7}$ & $<20$ & TVS (16 acute, 11 chronic) & ne & ne \\
\hline Copper, dissolved $(\mu \mathrm{g} / \mathrm{L})$ & $109 / 96$ & 13 & $<1$ & $\mathrm{nc}^{7}$ & $<20$ & TVS $^{8}$ & ne & ne \\
\hline Iron, dissolved $(\mu \mathrm{g} / \mathrm{L})$ & $68 / 30$ & 7 & $<5$ & 11 & 120 & ${ }^{4} 300$ DWS or no DWS & ne & ne \\
\hline Iron, total recoverable $(\mu \mathrm{g} / \mathrm{L})$ & $110 / 9$ & 11 & $<10$ & 77 & 1,578 & 1,000 (chronic) & 1 & 1 \\
\hline Lead, dissolved $(\mu \mathrm{g} / \mathrm{L})$ & $81 / 79$ & 10 & $<1$ & $\mathrm{nc}^{7}$ & 16 & TVS $^{8}$ & 2 & 2 \\
\hline Manganese, dissolved $(\mu \mathrm{g} / \mathrm{L})$ & $117 / 34$ & 14 & $<3$ & 21 & 1,600 & TVS,${ }^{8} 450$ DWS or no DWS & $6 \mathrm{DWS}$ & 19 DWS \\
\hline Mercury, total $(\mu \mathrm{g} / \mathrm{L})$ & $31 / 31$ & 4 & $<0.01$ & $\mathrm{nc}^{7}$ & $<0.2$ & 0.01 (chronic) & ne & ne \\
\hline Nickel, dissolved $(\mu \mathrm{g} / \mathrm{L})$ & $9 / 4$ & 2 & $<1$ & 1 & 1.88 & TVS $^{8}$ & ne & ne \\
\hline Selenium, dissolved $(\mu \mathrm{g} / \mathrm{L})$ & $62 / 55$ & 7 & $<1$ & $\mathrm{nc}^{7}$ & 2 & TVS (18.4 acute, 4.6 chronic) & ne & ne \\
\hline Silver, dissolved $(\mu \mathrm{g} / \mathrm{L})$ & $71 / 70$ & 9 & $<0.02$ & $\mathrm{nc}^{7}$ & $<1$ & TVS $^{8}$ & ne & ne \\
\hline Uranium, natural, dissolved $(\mu \mathrm{g} / \mathrm{L})$ & $25 / 9$ & 4 & $<1$ & 1.84 & 16 & ${ }^{9} 30$ & ne & ne \\
\hline Zinc, dissolved $(\mu \mathrm{g} / \mathrm{L})$ & $117 / 41$ & 14 & $<5$ & 20 & 140 & TVS $^{8}$ & ne & ne \\
\hline \multicolumn{9}{|c|}{ Suspended sediment } \\
\hline Suspended sediment (mg/L) & $9 / 0$ & 2 & 0.4 & 2 & 30 & -- & -- & -- \\
\hline \multicolumn{9}{|c|}{ Coliform bacteria } \\
\hline Total coliform (col/100 mL) & $11 / 1$ & 1 & 14 & 83 & ${ }^{10} 172$ & -- & -- & -- \\
\hline Fecal coliform $(\mathrm{col} / 100 \mathrm{~mL})$ & $20 / 16$ & 5 & $<3$ & $\mathrm{nc}^{7}$ & 43 & -- & -- & -- \\
\hline Escherichia coli $(\mathrm{col} / 100 \mathrm{~mL})$ & $29 / 0$ & 3 & 0 & 0 & 15.8 & 4, 11 126,205 & ne & ne \\
\hline
\end{tabular}

${ }^{1}$ Acute temperature standard (Colorado Department of Public Health and Environment, 2008c).

${ }^{2}$ Water years 1996-2006. A water year is a 12-month period beginning October 1 and ending September 30 of the following year. A water year is designated as the year in which it ends.

${ }^{3}$ Tenmile Creek below North Tenmile Creek, at Frisco, CO (USGS site number 09050100).

${ }^{4}$ Standard varies by stream segment. See Colorado Department of Public Health and Environment (2008d).

${ }^{5}$ USEPA secondary drinking-water standard, nonenforceable guideline. See U.S. Environmental Protection Agency (2008a).

${ }^{6}$ USEPA-recommended concentration limits for total phosphorus to control eutrophication in downstream water bodies; $0.05 \mathrm{mg} / \mathrm{L}$ is for streams that flow directly into lakes and reservoirs, $0.1 \mathrm{mg} / \mathrm{L}$ is for streams that do not flow directly into lakes and reservoirs (U.S. Environmental Protection Agency, 1986).

${ }^{7}$ Eighty percent or more of data were censored values. Median value could not be computed.

${ }^{8}$ Standard varies with hardness. See Colorado Department of Public Health and Environment (2008c).

${ }^{9}$ USEPA primary drinking-water standard, enforceable guideline. See U.S. Environmental Protection Agency (2008a).

${ }^{10}$ Maximum value does not include one value censored at greater than $200 \mathrm{col} / 100 \mathrm{~mL}$.

${ }^{11}$ Standard applies to recreational use. 
one from Ten Mile Creek above Wheeler Junction (site 97). This site is about $5 \mathrm{mi}$ upstream from the reservoir and, for this study, is considered not to directly flow into the reservoir as compared to a Tenmile Creek site just upstream from the inlet to the reservoir. The five samples were collected in February 2001 or May and August 2003; two were collected downstream from a wastewater treatment plant.

Trace-element data were available for 144 samples and 14 sites in the Tenmile Creek subwatershed (table 2). Concentrations of dissolved and total recoverable arsenic, dissolved chromium, copper, nickel, selenium, and silver, and total mercury typically were low throughout the subwatershed (table 9). Most concentrations of dissolved chromium and copper were less than laboratory reporting levels; the level was $20 \mu \mathrm{g} / \mathrm{L}$ for some samples. Concentrations of dissolved aluminum, cadmium, manganese, and zinc, and dissolved and total recoverable iron were elevated at the one site (Tenmile Creek at Kokomo, site 103) in a historical mining area in the upper Tenmile Creek subwatershed, at other sites farther downstream on Tenmile Creek to Frisco, and(or) one site on West Tenmile Creek. Laboratory reporting levels for dissolved aluminum were as high as $260 \mu \mathrm{g} / \mathrm{L}$ for some samples. Dissolved manganese and zinc concentrations in the Tenmile Creek subwatershed generally were much lower than those in the Snake and upper Blue River subwatersheds. The highest dissolved uranium concentration $(16 \mu \mathrm{g} / \mathrm{L})$ in the Blue River watershed was detected at Ten Mile Creek above Wheeler Junction (site 97).

The spatial distribution of median concentrations of cadmium, copper, manganese, and zinc for sites with six or more samples are illustrated in figures 11-14. In the Tenmile Creek subwatershed, the median concentration for each trace element generally was low relative to median concentrations in the Snake and upper Blue River subwatersheds. A study investigating water-quality trends in Dillon Reservoir using sediment cores found that Tenmile Creek contributed about 37 percent of the inflow to Dillon Reservoir during 1997 and 1998 and contributed the largest loads of aluminum, barium, and molybdenum (Greve and others, 2001). The source of the molybdenum is the Climax mining area in the headwaters of Tenmile Creek.

Trace-element water-quality standards adopted by the CDPHE for the protection of aquatic life were exceeded in seven samples collected at five sites throughout the Tenmile Creek subwatershed (fig. 15, table 6). Exceedances of aquatic life standards occurred in 4.9 percent of samples, which is the lowest occurrence of exceedances for the three subwatersheds upstream from Dillon Reservoir (table 7). The cadmium standard was exceeded at the most (four) sites in the Tenmile Creek subwatershed, followed by lead (two sites), and total recoverable iron (one site). Standards for these three trace elements also were exceeded in the most samples (cadmium, 6.7 percent; lead, 2.5 percent; and total recoverable iron, 0.9 percent) (table 7). Laboratory reporting levels for total mercury were greater than or equal to the standard for aquaticlife protection.
The domestic water-supply standard for dissolved manganese was exceeded in 19 samples at six sites on Tenmile Creek. All exceedances but one occurred at sites in and near Frisco (fig. 1). Domestic water-supply standards have not been adopted for dissolved iron and dissolved manganese for the main stem of Tenmile Creek from the headwaters to the confluence with West Tenmile Creek and most tributaries upstream from West Tenmile Creek (Colorado Department of Public Health and Environment, 2008d).

There were fewer exceedances of water-quality standards for trace elements in the Tenmile Creek subwatershed than those in the Snake and upper Blue subwatersheds (table 6). This may be because of the geology, engineering, and other reclamation work in the headwaters of Tenmile Creek, and sampling frequency and sites sampled. The ore deposit in the Climax mining area is a porphyry molybdenum deposit, and ore deposits in the Kokomo mining area and mining areas in the Snake and upper Blue River subwatersheds are sulfide-replacement orebodies. Historically, aquatic-life standards for cadmium, copper, lead, and zinc and water-supply standards for cadmium, lead, and zinc were exceeded in Tenmile Creek from its confluence with Kokomo Gulch in the headwaters to West Tenmile Creek (Northwest Colorado Council of Governments, 2012). Downstream from West Tenmile Creek, cadmium, copper, and zinc exceeded standards for aquatic life (Northwest Colorado Council of Governments, 2012). Diversion of clean water around mining-affected areas, water treatment with lime neutralization, and reclamation at the Climax Mine area in the headwaters of Tenmile Creek have resulted in substantial improvements to water quality in Tenmile Creek (GlobalInfoMine, 2008; White River National Forest, 2008). Few historical data from mining sites in the headwaters of Tenmile Creek were available for comparison to more recent data. At Tenmile Creek at Frisco (site 101), the median concentration of dissolved zinc was $180 \mu \mathrm{g} / \mathrm{L}$ for 16 samples collected between 1969 and 1972 and $61 \mu \mathrm{g} / \mathrm{L}$ for 70 samples collected between 1988 and 1997. Between 1995 and 2006, 144 samples were collected in the Tenmile Creek subwatershed for trace-element analysis compared to 725 and 552 in the Snake and upper Blue subwatersheds, respectively (table 2). All but five samples were collected from areas where mining has not occurred or were collected about $7 \mathrm{mi}$ downstream from mined areas.

Few suspended-sediment data were available for the Tenmile Creek subwatershed (tables 3 and 9). Only nine samples were collected at two sites; eight of the samples were collected at Tenmile Creek at 4th Street at Frisco (site 100). For these eight samples, the maximum concentrations occurred in June during snowmelt runoff.

A total of 60 water samples collected from eight sites were analyzed for coliform bacteria (table 2). Bacteria were detected in 25 samples. Three samples for total coliform, all collected from Tenmile Creek near the inlet to Dillon Reservoir in 1998 or 2000 , had counts of $150 \mathrm{col} / 100 \mathrm{~mL}$ or greater. Fecal coliform or E. coli were not detected in most samples. No E. coli count was greater than the CDPHE standard for recreation (Colorado Department of Public Health and Environment, 2008c, 2008d) (table 9). 


\section{Lower Blue River Watershed}

Water-quality data for the lower Blue River watershed were available for 33 sites and 1,143 samples (table 2). Of these sites and samples, data for physical properties were available for 32 sites and 984 samples (table 2). Water temperature values measured at the time of sample collection ranged between -3.0 and $21.5^{\circ} \mathrm{C}$ (table 10 ). Only three water temperature values measured at three sites along the Blue River were greater than the CDPHE acute water-quality standard of $13.0^{\circ} \mathrm{C}$ for October-May. Almost all (308 of 318) dissolvedoxygen concentrations were greater than or equal to $6.0 \mathrm{mg} / \mathrm{L}$, the CDPHE standard for aquatic life. Concentrations less than $6.0 \mathrm{mg} / \mathrm{L}$ were measured in only 3 percent of the samples. Dissolved-oxygen concentrations less than $6.0 \mathrm{mg} / \mathrm{L}$ were measured at two Blue River sites (Blue River at Knorr (site 114) and at the outlet from Dillon Reservoir) during April and September 1999, June 2000, and October 2001 and at four Straight Creek sites during July 1997, June 2000, October 2003, and August 2005.

One or more specific conductance measurements were made at 26 sites in the lower Blue River watershed (table 10); values ranged from 35 to $827 \mu \mathrm{S} / \mathrm{cm}$ (table 10). Most specific conductance values (650 of 731) were less than or equal to $300 \mu \mathrm{S} / \mathrm{cm}$. Values greater than $300 \mu \mathrm{S} / \mathrm{cm}$ were measured at seven sites each on the Blue River and Straight Creek. Specific conductance values greater than $400 \mu \mathrm{S} / \mathrm{cm}$ occurred most frequently in March through mid-May before snowmelt runoff. Most (308 of 314) values of $\mathrm{pH}$ in the lower Blue River watershed were within the CDPHE standard of 6.5 and 9.0 (table 10). Values were slightly higher downstream from Green Mountain Reservoir than upstream from the reservoir. Six measurements greater than 9.0 were measured at the Blue River at Trough (site 116, four samples), Blue River below Dillon Reservoir (site 117, one sample), and Rock Creek near Dillon (site 123, one sample). All median $\mathrm{pH}$ values were between 6.7 and 8.3 (fig. 7). Unlike areas in the upper Blue River watershed, sulfide-rich ore deposits are not found in the lower Blue River watershed, reducing the possibility of acidic drainage. The ANC at sites in the lower Blue River watershed ranged between 4 and $128 \mathrm{mg} / \mathrm{L}$ and the median concentration was $50 \mathrm{mg} / \mathrm{L}$. The buffering capacity generally was higher downstream from Green Mountain Reservoir than upstream from the reservoir.

Water type could only be classified for 14 samples at three sites on the Blue River. The primary water type was calcium sulfate. For a few samples, the water was a calcium bicarbonate or calcium mixed-sulfate-bicarbonate type.

All concentrations of chloride, sulfate, and dissolved solids were less than CDPHE domestic water-supply standards or the USEPA-recommended limit (table 10). Chloride concentrations tended to be greater than $20 \mathrm{mg} / \mathrm{L}$ in Straight Creek and less than $10 \mathrm{mg} / \mathrm{L}$ in the Blue River and other tributaries. Concentrations of chloride and magnesium tended to be higher in the months prior to snowmelt runoff than during runoff. Magnesium concentrations also tended to be higher in Straight
Creek. This may be from deicers, including magnesium chloride, that are applied to the interstate highway that is adjacent to Straight Creek. About 80 percent of chloride and magnesium samples were collected from Straight Creek. Sulfate concentrations were less than or equal to $100 \mathrm{mg} / \mathrm{L}$ (table 10). Dissolved-solids concentrations were less or equal to $350 \mathrm{mg} / \mathrm{L}$ (table 10). Hardness values greater than the median of $92 \mathrm{mg} / \mathrm{L}$ primarily were detected in samples collected from the Blue River. Major-ion and dissolved-solids concentrations and hardness values were lower during snowmelt runoff than during the months with low streamflow.

A total of 758 samples collected at 28 sites in the lower Blue River watershed were available for nutrient analysis (table 2). Most (72 percent) samples were collected at six sites: Blue River below Dillon, CO (site 118), Blue River at inlet to Green Mountain Reservoir (site 113), Blue River below Green Mountain Reservoir (site 119), Straight Creek at mouth (site 129), Blue River below Silverthorne (site 120), and Straight Creek above Silverthorne (site 127). Total phosphorus samples were collected at all 28 sites. A summary of the nutrient data are listed in table 10 .

Most (84 percent) total ammonia concentrations were less than laboratory reporting levels (table 10). No concentration was greater than the CDPHE aquatic-life standard, which ranged from 0.73 to $33 \mathrm{mg} / \mathrm{L}$ for the acute standard and 0.30 to 6.7 for the chronic standard. Un-ionized ammonia concentrations in 20 samples collected during 1997 and 1998 were less than or equal to $0.015 \mathrm{mg} / \mathrm{L}$. All eight nitrite samples had concentrations less than the CDPHE standard of $0.05 \mathrm{mg} / \mathrm{L}$ for aquatic-life protection. The maximum nitrate concentration for all sites in the watershed was $0.672 \mathrm{mg} / \mathrm{L}$, well below the CDPHE domestic water-supply standard of $10 \mathrm{mg} / \mathrm{L}$. Median nitrate concentrations for the five sites with six or more samples in the lower Blue River watershed were less than or equal to $0.50 \mathrm{mg} / \mathrm{L}$ (fig. 9). Total nitrogen data only were available for 16 samples collected from eight sites. Concentrations greater than $1.0 \mathrm{mg} / \mathrm{L}$ were detected during 1998 and 1999 in three Blue River below Dillon Reservoir (site 117) samples and one Straight Creek (site 128) sample.

Orthophosphate concentrations were less than or equal to $0.031 \mathrm{mg} / \mathrm{L}$ (table 10), and most total phosphorus concentrations were less than $0.05 \mathrm{mg} / \mathrm{L}$. Median total phosphorus concentrations for the 14 sites with 6 or more samples were less than or equal to $0.03 \mathrm{mg} / \mathrm{L}$ (fig. 10). The USEPArecommended total phosphorus concentration of $0.05 \mathrm{mg} / \mathrm{L}$ for streams that directly flow into reservoirs was exceeded in one Blue River sample collected during 1999 at the inlet to Green Mountain Reservoir (site 113). The recommended total phosphorus concentration of $0.1 \mathrm{mg} / \mathrm{L}$ for streams that do not directly flow into reservoirs was exceeded in 27 samples collected between 1997 and 2003 from 6 sites; 5 samples from two Blue River sites and 22 samples from four Straight Creek sites. The highest concentrations generally were detected between May and August. These months typically have greater streamflow and higher sediment concentrations from snowmelt runoff and thunderstorm activity than other months. In 
Table 10. Summary of the number of samples and sites, minimum, median, and maximum values, and Colorado Department of Public Health and Environment in-stream waterquality standards for stream-water samples in the lower Blue River watershed, Blue River watershed, Colorado, 1995 through 2006.

[No., number; ${ }^{\circ} \mathrm{C}$, degrees Celsius; $\mathrm{mg} / \mathrm{L}$, milligrams per liter; $\mu \mathrm{S} / \mathrm{cm}$, microsiemens per centimeter at 25 degrees Celsius; --. no standard; $\mathrm{CaCO}_{3}$, calcium carbonate; $\mathrm{ft}^{3} / \mathrm{s}$, cubic feet per second; $\mathrm{HCO}_{3}^{-}$, bicarbonate; DWS, domestic water supply; ne, no exceedance; <, less than; N, nitrogen; nc, not computed; TVS, table value standard; P, phosphorus; $\mu$ g/L, micrograms per liter; col/100 mL, colonies per 100 milliliters. Waterquality standards are from Colorado Department of Public Health and Environment (2008c, 2008d) unless otherwise noted; standards are for protection of aquatic life unless otherwise stated. Standards may not apply to every site where data were collected. See table 6 for additional information on water-quality standards for trace elements]

\begin{tabular}{|c|c|c|c|c|c|c|c|c|}
\hline $\begin{array}{l}\text { Property or constituent } \\
\text { (reporting units) }\end{array}$ & $\begin{array}{l}\text { No. of } \\
\text { samples/ } \\
\text { no. of } \\
\text { censored } \\
\text { values }\end{array}$ & $\begin{array}{l}\text { No. of } \\
\text { sites }\end{array}$ & $\begin{array}{l}\text { Minimum } \\
\text { value }\end{array}$ & $\begin{array}{l}\text { Median } \\
\text { value }\end{array}$ & $\begin{array}{l}\text { Maximum } \\
\text { value }\end{array}$ & $\begin{array}{c}\text { In-stream } \\
\text { water-quality standard }\end{array}$ & $\begin{array}{l}\text { No. of sites with } \\
\text { measurement or } \\
\text { concentration greater } \\
\text { than censoring limit } \\
\text { that do not meet } \\
\text { water-quality standard }\end{array}$ & $\begin{array}{l}\text { No. of samples with } \\
\text { measurement or } \\
\text { concentration greater } \\
\text { than censoring limit } \\
\text { that do not meet } \\
\text { water-quality standard }\end{array}$ \\
\hline \multicolumn{9}{|c|}{ Physical properties } \\
\hline Temperature $\left({ }^{\circ} \mathrm{C}\right)$ & $859 / 2$ & 31 & -3 & 5.0 & 21.5 & $\begin{array}{l}\text { June-September, } 21.2^{\circ} \mathrm{C} ;{ }^{1} \\
\text { October-May, } 13.0^{\circ} \mathrm{C}\end{array}$ & 3 (acute, October-May) & 3 (acute, October-May) \\
\hline Oxygen, dissolved (mg/L) & $318 / 0$ & 23 & 3.9 & 9.6 & ${ }^{2} 14$ & 6.0 & 6 & 10 \\
\hline Specific conductance $(\mu \mathrm{S} / \mathrm{cm})$ & $731 / 0$ & 26 & 35 & 207 & 827 & -- & -- & -- \\
\hline pH, field (standard units) & $314 / 0$ & 24 & 6.5 & 7.9 & 9.4 & $6.5-9.0$ & 3 & 6 \\
\hline $\begin{array}{l}\text { Acid neutralizing capacity } \\
\qquad\left(\mathrm{mg} / \mathrm{L} \text { as } \mathrm{CaCO}_{3}\right)\end{array}$ & $169 / 0$ & 11 & 4 & 50 & 128 & -- & -- & -- \\
\hline Discharge, annual mean $\left(\mathrm{ft}^{3} / \mathrm{s}\right)$ & $311 / 0$ & ${ }^{4} 1$ & 204.7 & 363.6 & 720 & -- & -- & -- \\
\hline \multicolumn{9}{|c|}{ Major ions } \\
\hline $\begin{array}{l}\text { Bicarbonate, dissolved } \\
\left(\mathrm{mg} / \mathrm{L} \text { as } \mathrm{HCO}_{3}^{-}\right)\end{array}$ & $14 / 0$ & 3 & 37 & 42 & 62 & -- & -- & -- \\
\hline Calcium, dissolved (mg/L) & $112 / 0$ & 10 & 7.2 & 17.0 & 53.0 & -- & -- & -- \\
\hline Chloride, dissolved (mg/L) & $98 / 0$ & 8 & 0.28 & 24 & 145 & 250 DWS & ne & ne \\
\hline Magnesium, dissolved (mg/L) & $130 / 0$ & 10 & 1.6 & 3.9 & 14.2 & -- & -- & -- \\
\hline Sulfate, dissolved $(\mathrm{mg} / \mathrm{L})$ & $144 / 30$ & 16 & $<3$ & 41 & 100 & 250 DWS & ne & ne \\
\hline Dissolved solids (mg/L) & $146 / 0$ & 16 & 16 & 132 & 350 & ${ }^{5} 500$ & ne & ne \\
\hline Hardness $(\mathrm{mg} / \mathrm{L})$ & $327 / 0$ & 23 & 10 & 92 & 212 & -- & -- & -- \\
\hline \multicolumn{9}{|c|}{ Nutrients } \\
\hline Total ammonia (mg/L as N) & $183 / 153$ & 21 & $<0.001$ & $n c^{6}$ & 0.5 & TVS & ne & ne \\
\hline $\begin{array}{l}\text { Un-ionized ammonia } \\
\quad(\text { computed, } \mathrm{mg} / \mathrm{L} \text { as } \mathrm{N})\end{array}$ & $20 / 3$ & 3 & $<0.0001$ & 0.001 & 0.015 & -- & -- & -- \\
\hline Nitrite $(\mathrm{mg} / \mathrm{L}$ as $\mathrm{N})$ & $8 / 5$ & 4 & $<0.003$ & $<0.01$ & 0.012 & 0.05 & ne & ne \\
\hline Nitrate $(\mathrm{mg} / \mathrm{L}$ as $\mathrm{N})$ & $386 / 0$ & 7 & 0.056 & 0.211 & 0.672 & 10 DWS & ne & ne \\
\hline Nitrogen, total (mg/L as N) & $16 / 0$ & 8 & 0.31 & 0.52 & 4.06 & -- & -- & -- \\
\hline Orthophosphate (mg/L as P) & $399 / 12$ & 9 & $<0.0001$ & 0.001 & 0.031 & -- & -- & -- \\
\hline Phosphorus, total (mg/L as $\mathrm{P}$ ) & $669 / 89$ & 28 & $<0.002$ & 0.009 & 1.68 & ${ }^{7} 0.05,0.1$ & 7 & 27 \\
\hline
\end{tabular}


Table 10. Summary of the number of samples and sites, minimum, median, and maximum values, and Colorado Department of Public Health and Environment in-stream waterquality standards for stream-water samples in the lower Blue River watershed, Blue River watershed, Colorado, 1995 through 2006.-Continued

[No., number; ${ }^{\circ} \mathrm{C}$, degrees Celsius; $\mathrm{mg} / \mathrm{L}$, milligrams per liter; $\mu \mathrm{S} / \mathrm{cm}$, microsiemens per centimeter at 25 degrees Celsius; --. no standard; $\mathrm{CaCO}_{3}$, calcium carbonate; $\mathrm{ft}^{3} / \mathrm{s}$, cubic feet per second; $\mathrm{HCO}_{3}^{-}$, bicarbonate; DWS, domestic water supply; ne, no exceedance; <, less than; N, nitrogen; nc, not computed; TVS, table value standard; P, phosphorus; $\mu \mathrm{g} / \mathrm{L}$, micrograms per liter; col/100 mL, colonies per $100 \mathrm{milliliters.} \mathrm{Water-}$ quality standards are from Colorado Department of Public Health and Environment (2008c, 2008d) unless otherwise noted; standards are for protection of aquatic life unless otherwise stated. Standards may not apply to every site where data were collected. See table 6 for additional information on water-quality standards for trace elements]

\begin{tabular}{|c|c|c|c|c|c|c|c|c|}
\hline $\begin{array}{l}\text { Property or constituent } \\
\text { (reporting units) }\end{array}$ & $\begin{array}{l}\text { No. of } \\
\text { samples/ } \\
\text { no. of } \\
\text { censored } \\
\text { values }\end{array}$ & $\begin{array}{l}\text { No. of } \\
\text { sites }\end{array}$ & $\begin{array}{l}\text { Minimum } \\
\text { value }\end{array}$ & $\begin{array}{c}\text { Median } \\
\text { value }\end{array}$ & $\begin{array}{l}\text { Maximum } \\
\text { value }\end{array}$ & $\begin{array}{c}\text { In-stream } \\
\text { water-quality standard }\end{array}$ & $\begin{array}{l}\text { No. of sites with } \\
\text { measurement or } \\
\text { concentration greater } \\
\text { than censoring limit } \\
\text { that do not meet } \\
\text { water-quality standard }\end{array}$ & $\begin{array}{l}\text { No. of samples with } \\
\text { measurement or } \\
\text { concentration greater } \\
\text { than censoring limit } \\
\text { that do not meet } \\
\text { water-quality standard }\end{array}$ \\
\hline \multicolumn{9}{|c|}{ Trace elements } \\
\hline Aluminum, dissolved $(\mu \mathrm{g} / \mathrm{L})$ & $155 / 138$ & 15 & $<5$ & $\mathrm{nc}^{6}$ & 150 & -- & -- & -- \\
\hline Arsenic, dissolved $(\mu \mathrm{g} / \mathrm{L})$ & $195 / 194$ & 17 & $<0.1$ & $\mathrm{nc}^{6}$ & $<100$ & 340 (acute) & ne & ne \\
\hline Cadmium, dissolved $(\mu \mathrm{g} / \mathrm{L})$ & $194 / 181$ & 17 & $<0.1$ & $\mathrm{nc}^{6}$ & $<1.5$ & TVS $^{8}$ & 1 & 1 \\
\hline Chromium, dissolved $(\mu \mathrm{g} / \mathrm{L})$ & $40 / 40$ & 3 & $<1$ & $n c^{6}$ & $<4$ & TVS (16 acute, 11 chronic) & ne & ne \\
\hline Copper, dissolved $(\mu \mathrm{g} / \mathrm{L})$ & $240 / 211$ & 20 & $<0.002$ & $\mathrm{nc}^{6}$ & $<10$ & TVS $^{8}$ & 2 & 5 \\
\hline Iron, dissolved $(\mu \mathrm{g} / \mathrm{L})$ & $157 / 83$ & 17 & $<3$ & 11 & 230 & 300 DWS & ne & ne \\
\hline Iron, total recoverable $(\mu \mathrm{g} / \mathrm{L})$ & $209 / 41$ & 21 & $<10$ & 37 & 2,900 & 1,000 (chronic) & 4 & 4 \\
\hline Lead, dissolved $(\mu \mathrm{g} / \mathrm{L})$ & $174 / 170$ & 18 & $<0.08$ & $\mathrm{nc}^{6}$ & 10 & TVS $^{8}$ & 1 & 1 \\
\hline Manganese, dissolved $(\mu \mathrm{g} / \mathrm{L})$ & $269 / 122$ & 22 & $<1$ & 4 & 90 & TVS,${ }^{8} 50 \mathrm{DWS}$ & 1 DWS & 3 DWS \\
\hline Mercury, total $(\mu \mathrm{g} / \mathrm{L})$ & 96/96 & 9 & $<0.1$ & $\mathrm{nc}^{6}$ & $<0.2$ & 0.01 & ne & ne \\
\hline Nickel, dissolved $(\mu \mathrm{g} / \mathrm{L})$ & $40 / 32$ & 3 & $<0.9$ & $\mathrm{nc}^{6}$ & 2 & TVS $^{8}$ & ne & ne \\
\hline Selenium, dissolved $(\mu \mathrm{g} / \mathrm{L})$ & $152 / 151$ & 14 & $<0.4$ & $\mathrm{nc}^{6}$ & $<5$ & TVS (18.4 acute, 4.6 chronic) & ne & ne \\
\hline Silver, dissolved $(\mu \mathrm{g} / \mathrm{L})$ & $161 / 161$ & 16 & $<0.06$ & $n c^{6}$ & $<2$ & TVS $^{8}$ & ne & ne \\
\hline Uranium, natural, dissolved $(\mu \mathrm{g} / \mathrm{L})$ & $47 / 9$ & 5 & $<0.7$ & 1.8 & 4.8 & ${ }^{9} 30$ & ne & ne \\
\hline Zinc, dissolved $(\mu \mathrm{g} / \mathrm{L})$ & $260 / 128$ & 21 & $<2.2$ & 5 & 600 & TVS $^{8}$ & 2 & 2 \\
\hline \multicolumn{9}{|c|}{ Suspended sediment } \\
\hline Suspended sediment (mg/L) & $6 / 0$ & 3 & 0.7 & 3 & 7 & -- & -- & -- \\
\hline \multicolumn{9}{|c|}{ Coliform bacteria } \\
\hline Total coliform (col/100 mL) & $60 / 0$ & 4 & 5 & 38 & 770 & -- & -- & -- \\
\hline Fecal coliform (col/100 mL) & $23 / 16$ & 4 & 0 & $<3$ & 9 & -- & -- & -- \\
\hline Escherichia coli $(\mathrm{col} / 100 \mathrm{~mL})$ & $59 / 0$ & 11 & 0 & 0 & 921 & ${ }^{10,11} 126,630$ & 2 & 2 \\
\hline
\end{tabular}

'Acute temperature standard (Colorado Department of Public Health and Environment, 2008c)

${ }^{2}$ Maximum value does not include value censored at greater than $15 \mathrm{mg} / \mathrm{L}$.

${ }^{3}$ Water years 1996-2006. A water year is a 12-month period beginning October 1 and ending September 30 of the following year. A water year is designated as the year in which it ends.

${ }^{4}$ Blue River below Green Mountain Reservoir, CO (USGS site number 09057500).

${ }^{5}$ USEPA secondary drinking-water standard, nonenforceable guideline. See U.S. Environmental Protection Agency (2008a).

${ }^{6}$ Eighty percent or more of data were censored values. Median value could not be computed.

${ }^{7}$ USEPA-recommended concentration limits for total phosphorus to control eutrophication in downstream water bodies; $0.05 \mathrm{mg} / \mathrm{L}$ is for streams that flow directly into lakes and reservoirs, $0.1 \mathrm{mg} / \mathrm{L}$ is for streams that do not flow directly into lakes and reservoirs (U.S. Environmental Protection Agency, 1986).

${ }^{8}$ Standard varies with hardness. See Colorado Department of Public Health and Environment (2008c).

${ }^{9}$ USEPA primary drinking-water standard, enforceable guideline. See U.S. Environmental Protection Agency (2008a)

${ }^{10}$ Standard varies by stream segment. See Colorado Department of Public Health and Environment (2008d).

${ }^{11}$ Standard applies to recreational use. 
2007, the average concentration of particulate phosphorus at Straight Creek above the confluence with Blue River was about double the average for Blue River at inlet to Green Mountain Reservoir (site 113) (Lewis, 2008). Straight Creek likely receives increased loading of sediment from slope erosion and roadway traction sand along the interstate highway, and phosphorus tends to sorb to particulate matter.

Monitoring of total phosphorus in the Blue River just upstream from Green Mountain Reservoir was conducted in the mid-to late 1980s; concentrations ranged from 0.011 to $0.016 \mathrm{mg} / \mathrm{L}$ (Northwest Colorado Council of Governments, 2012). Total phosphorus concentrations in samples collected from 1996 through 2005 at Blue River at Inlet to Green Mountain Reservoir (site 113) ranged from 0.004 to $0.052 \mathrm{mg} / \mathrm{L}$.

Trace-element data were available for 340 samples collected at 27 sites in the lower Blue River watershed (table 2). All but 18 samples collected at five sites were from the Blue River or Straight Creek. Most trace-element concentrations in the lower Blue River watershed were less than those upstream from Dillon Reservoir. Concentrations of dissolved aluminum, arsenic, cadmium, chromium, copper, lead, nickel, selenium, and silver and total mercury generally were less than laboratory reporting levels, although elevated concentrations were measured in some samples (table 10). Dissolved iron concentrations greater than $80 \mu \mathrm{g} / \mathrm{L}$ were measured in some samples from Cataract, Spruce, Straight, and Slate Creeks, but most concentrations of dissolved iron were less than $60 \mu \mathrm{g} / \mathrm{L}$. Total recoverable iron concentrations greater than $100 \mu \mathrm{g} / \mathrm{L}$ were measured in some samples from sites along Rock, Spruce, Straight, and Slate Creeks and Blue River at City Road 1 (site 111). For both forms of iron, concentrations generally were lowest on the Blue River between Dillon and Green Mountain Reservoirs. Forty-five percent of the dissolved manganese concentrations were less than laboratory reporting levels. The maximum concentration of $90 \mu \mathrm{g} / \mathrm{L}$ was detected at Blue River at City Road 1 (site 111) near Kremmling. Manganese concentrations detected at Straight Creek sites ranged from less than 3 to $48 \mu \mathrm{g} / \mathrm{L}$. Dissolved uranium concentrations were less than or equal to $4.8 \mu \mathrm{g} / \mathrm{L}$. About one-half of the dissolved zinc concentrations were less than laboratory reporting levels. Zinc concentrations were highest $(600 \mu \mathrm{g} / \mathrm{L}$ maximum, $82 \mu \mathrm{g} / \mathrm{L}$ next highest value) at sites in the Blue River between Dillon Reservoir and Green Mountain Reservoir and Straight Creek (maximum $88 \mu \mathrm{g} / \mathrm{L}$ ). Elevated concentrations of dissolved manganese and zinc in samples collected at the Blue River below Dillon, CO (site 118), just downstream from Dillon Reservoir, indicate that one possible source for the trace elements in the lower Blue River is the mining-affected areas in the Snake and upper Blue River subwatersheds. Median concentrations of dissolved copper, manganese, and zinc were less than or equal to $7.8,45$, and $78 \mu \mathrm{g} / \mathrm{L}$, respectively, for sites with six or more samples (figs. 12-14), when sites with low censoring limits are considered. Median concentrations could not be determined for dissolved cadmium because 80 percent or more of the data were censored (computation of summary statistics for sites with censored values is described in the "Censored Values" section) for each site with six or more samples.

Although many of the concentrations of dissolved metals measured in the lower Blue River watershed were below laboratory reporting levels, exceedances of trace-element water-quality standards for the protection of aquatic life still occurred. Concentrations of dissolved cadmium, copper, lead, manganese, and zinc and total recoverable iron exceeded waterquality standards in some samples. Water-quality standards were exceeded at 8 sites in the watershed (fig. 15, table 6). Exceedances occurred in 3.8 percent of samples collected in the lower Blue River watershed, similar to the proportion of exceedances in the Tenmile Creek subwatershed but much less than those in the Snake River and upper Blue River subwatersheds (table 7). The chronic standard for total recoverable iron was exceeded at the most (four) sites. One exceedance occurred at Spruce Creek (site 124), which is on the State of Colorado 2008 Monitoring and Evaluation list for total recoverable iron (Colorado Department of Public Health and Environment, 2008a). Laboratory reporting levels for total mercury were greater than the standard for aquatic-life protection. The domestic water-supply standard for manganese was exceeded in three samples at Blue River at City Road 1 (site 111).

Few suspended-sediment data were available for the lower Blue River watershed (tables 2 and 10). Two samples each were collected at three sites. Suspended-sediment concentrations were low, $7 \mathrm{mg} / \mathrm{L}$ or less.

A total of 141 water samples collected from 17 sites were analyzed for coliform bacteria (table 2); 1 sample was analyzed for both total coliform and E. coli. Bacteria were detected in 91 samples. Counts of total coliform in 10 samples collected from Straight Creek were elevated $(147 \mathrm{col} / 100 \mathrm{~mL}$ or more, maximum count $770 \mathrm{col} / 100 \mathrm{~mL}$ ). Counts of fecal coliform were low, $9 \mathrm{col} / 100 \mathrm{~mL}$ or less (table 10). E. coli was not detected or was detected at counts less than $82 \mathrm{col} / 100 \mathrm{~mL}$ in 56 of 59 samples. One Slate Creek site and a Blue River site (Blue River at City Road 1, site 111) had one sample each of $E$. coli that was greater than the CDPHE standard for recreation of $126 \mathrm{col} / 100 \mathrm{~mL}$ (Colorado Department of Public Health and Environment, 2008c, 2008d). The two samples were collected during June and July 2001. One stream, Slate Creek, is on the State of Colorado Monitoring and Evaluation list for E. coli (Colorado Department of Public Health and Environment, 2008a).

\section{Reservoirs}

Within the Blue River watershed, water-quality data were available for six water bodies. Dillon and Green Mountain Reservoirs were the only two water bodies with more than 2 days of water-sample collection. These two reservoirs are the focus of this section. Water quality in Dillon and Green Mountain Reservoirs is affected by such things as inflow of water from major and minor tributaries, direct surface runoff, in-reservoir processes, and atmospheric 
deposition. For each reservoir, data on physical properties (water temperature, specific conductance, dissolved oxygen, Secchi disk transparency), suspended sediment, nutrients (nitrate and total phosphorus), and algae (chlorophyll- $a$ ) are summarized and analyzed. Trophic-state indices are estimated for both reservoirs, and temporal trend analyses are discussed for Dillon Reservoir.

\section{Dillon Reservoir}

In Dillon Reservoir, water was collected at 18 waterquality sampling sites on one or more days between January 1966 and October 2007. For most (13 of 18) sites, water samples were collected on six or fewer days. For five sites, Dillon Reservoir at Blue River arm (site 132), Dillon Reservoir at Snake River arm (site 133), Dillon Reservoir at Tenmile Creek arm (site 134), Dillon Reservoir near Dam (west) (henceforth, Dillon Reservoir near dam) (site 135), and South Platte Dillon Reservoir at outlet (site 136) (fig. 5, Appendix 1), water-quality samples were collected on 131 or more days (table 11). Figure 16 shows time-series plots of water-sample collection days for these five sites. Water-quality samples were collected at the top of the water column and every $5 \mathrm{~m}$ (16.4 ft) of depth for Dillon Reservoir near dam (site 135) on all collection days (table 11) and at the top and bottom of the water column for sites 132, 133, and 134 on the reservoir arms of the reservoir on 24 collection days at each site. The discussion in the remainder of this section is focused on Dillon Reservoir near dam (site 135). This site is the index site for the reservoir. At this site, data for nitrate, total phosphorus, and chlorophyll- $a$ were available for all years from 1981 through 2007 except for 1983; data for specific conductance, dissolved oxygen, and suspended sediment were available starting in 1984 . Temperature data were available starting in 2002. Temporal trend analysis was conducted on Secchi disk transparency, dissolved nitrate, total phosphorus, and chlorophyll- $a$ data for 1984 through 2007.

Water temperature in Dillon Reservoir ranged between 0.0 and $17.8^{\circ} \mathrm{C}$ (table 12) and varied seasonally. The median temperature of all water column measurements by month was coldest $\left(2.4^{\circ} \mathrm{C}\right)$ in February and warmest $\left(6.9^{\circ} \mathrm{C}\right)$ in September at the dam site (site 135). No temperature data were available for March, April, and December. The reservoir typically is ice-covered from December into May. Thermal stratification typically began in May and mixing started in fall. Measurements made during January and February 2003 indicated that stratification occurred during winter. Water-quality standards established by the CDPHE for aquatic-life protection were not exceeded for temperature (Colorado Department of Public Health and Environment, 2008c).

Dissolved-oxygen concentrations ranged between 1.4 and $10.4 \mathrm{mg} / \mathrm{L}$ (table 12). During thermal stratification between 2002 and 2007, there were 18 sampling days during July, August, September, and(or) October when dissolvedoxygen concentrations in the epilimnion and metalimnion were less than the minimum CDPHE water-quality standard of $6.0 \mathrm{mg} / \mathrm{L}$. Anoxic (without oxygen) conditions were not detected. Only the minimum concentration, measured near the bottom of the reservoir water column during June 2004, approached $1 \mathrm{mg} / \mathrm{L}$. Except for a maximum value of $553 \mu \mathrm{S} / \mathrm{cm}$, specific conductance was less than $350 \mu \mathrm{S} / \mathrm{cm}$.

Secchi disk transparency at the dam site (site 135) ranged between 1.1 and $11.0 \mathrm{~m}$ below the water surface (table 12). The median transparency of $3.4 \mathrm{~m}$ was slightly deeper than the median transparency of $3.2 \mathrm{~m}$ for the southern Rocky Mountains (U.S. Environmental Protection Agency, 2000b). By month, the median transparency for Dillon Reservoir was greatest (6.6 m) during April and lowest

Table 11. Time period of sample collection, number of sample days, and number of individual samples for selected sites in Dillon and Green Mountain Reservoirs, Blue River watershed, Colorado.

[See figure 16 for graphical display of time periods; see figure 5 and Appendix 1 for site location and site information]

\begin{tabular}{|c|c|c|c|c|}
\hline $\begin{array}{c}\text { Site number } \\
\text { in this report } \\
\text { (fig. 5, Appendix 1) }\end{array}$ & Site name in database & Time period of sample collection & $\begin{array}{c}\text { Number of } \\
\text { sample days }\end{array}$ & $\begin{array}{c}\text { Number of } \\
\text { individual samples' }\end{array}$ \\
\hline \multicolumn{5}{|c|}{ Dillon Reservoir } \\
\hline 133 & Dillon Reservoir at Snake R arm & ${ }^{2} 1981-1995,1997-2001,2003,2006,2007$ & 278 & 302 \\
\hline 134 & Dillon Reservoir at Tenmile $\mathrm{Cr}$ arm & ${ }^{2} 1981-1995,1997-2001,2003,2006,2007$ & 277 & 301 \\
\hline 135 & Dillon Reservoir nr Dam (west) & ${ }^{2} 1981-2007$ & 338 & 3,670 \\
\hline 137 & $\begin{array}{l}\text { Green Mountain Reservoir between } \\
\text { Heeney and dam }\end{array}$ & 1984-1993, 1996, 1997, 1999, 2005, 2007 & 209 & 2,087 \\
\hline 138 & Green Mnt Reservoir site GA & 1984-1993, 1996, 1997, 1999, 2005, 2007 & 165 & 191 \\
\hline 139 & Green Mnt Reservoir site GB & 1984-1993, 1997, 1999, 2005, 2007 & 180 & 204 \\
\hline 140 & Green Mnt Reservoir site GC & $1984-1993,1997,1999,2005,2007$ & 189 & 213 \\
\hline
\end{tabular}

${ }^{1}$ When number of individual samples differs from number of sample days, it is because individual samples for analysis were collected at multiple depths in the reservoir on the same day.

${ }^{2}$ No samples in 1983. 


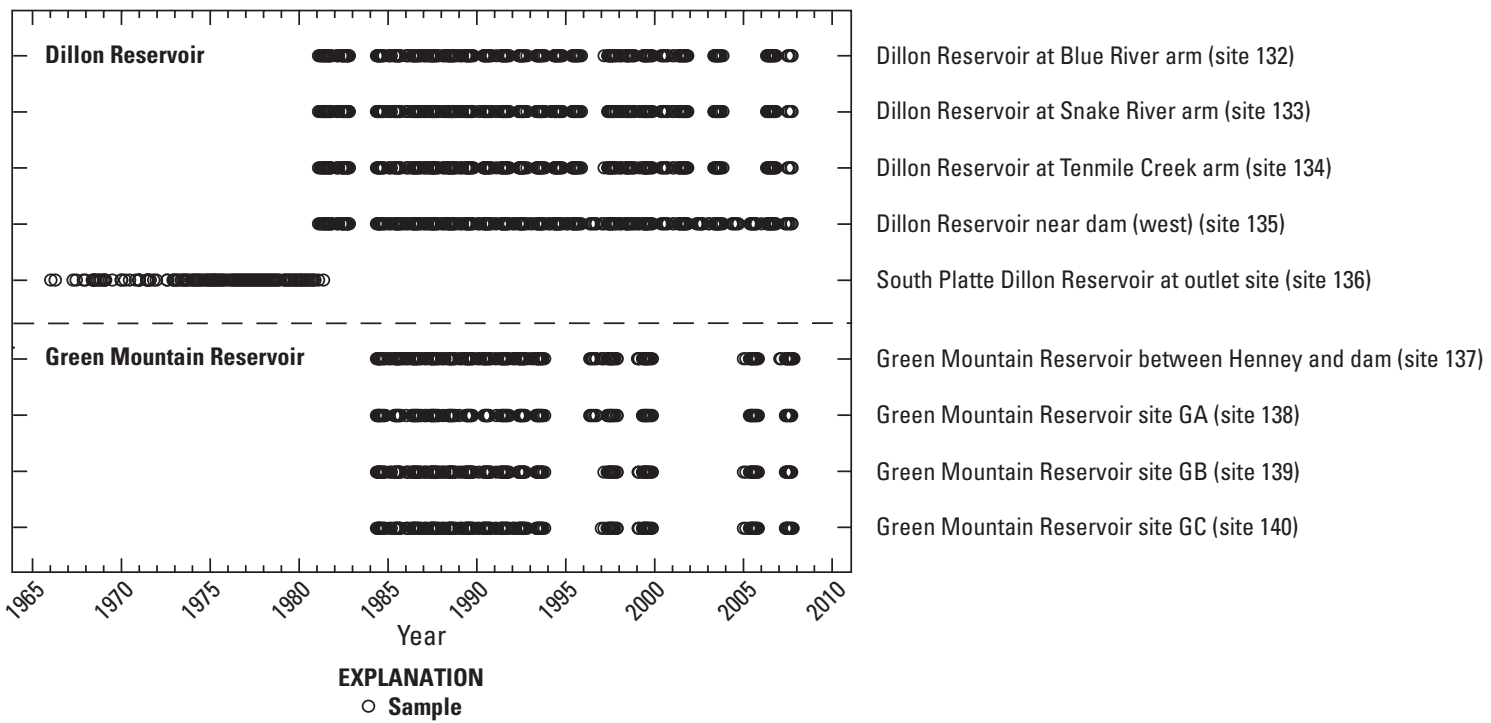

Figure 16. Time series of sample collection for selected sites in Dillon and Green Mountain Reservoirs, Blue River watershed, 1966-2007.

(2.4-2.9 m) during May, June, and July for 1984-2007. The opposite pattern was observed for suspended sediment. The median concentration of suspended sediment was at a minimum $(0.4 \mathrm{mg} / \mathrm{L})$ during April and at a maximum (1.4-1.7 mg/L) during May, June, and July for 1984-2007. Light transmittal is reduced when there is more suspended material in the reservoir. Therefore, the reduced transparency during May, June, and July (1984-2007) likely occurs because of the higher suspended-sediment concentrations entering the reservoir from tributary inflows during snowmelt runoff.

Dissolved nitrate concentrations were low at the dam site (site 135) (table 12). The maximum concentration of $0.430 \mathrm{mg} / \mathrm{L}$ was well below the CDPHE domestic watersupply standard of $10 \mathrm{mg} / \mathrm{L}$ (Colorado Department of Public Health and Environment, 2008c, 2008d). Median concentrations during 2007 in the top $15 \mathrm{~m}$ of the water column decreased from a high $(0.258 \mathrm{mg} / \mathrm{L})$ during May when inflow to the reservoir was greatest to a low $(0.076 \mathrm{mg} / \mathrm{L})$ during August when nutrient consumption by biota was highest. Lewis and others (1984) reported that nutrient limitation in Dillon Reservoir can alternate between nitrogen and phosphorus limitation during summer stratification, and algal growth may be suppressed when the nitrate concentration in the top $5 \mathrm{~m}$ of the water column is less than $0.010 \mathrm{mg} / \mathrm{L}$ (Morris and Lewis, 1988). Nitrate concentrations below this value have not occurred in Dillon Reservoir since 1994.

Total phosphorus concentrations ranged between 0.002 and $0.106 \mathrm{mg} / \mathrm{L}$ (table 12). The median concentration of $0.005 \mathrm{mg} / \mathrm{L}$ was less than the reference condition of $0.015 \mathrm{mg} / \mathrm{L}$ for total phosphorus in lakes and reservoirs in the southern Rocky Mountains (U.S. Environmental Protection Agency, 2000b). Historically, nutrient enrichment in the reservoir because of phosphorus loading from natural and anthropogenic sources has been a water-quality issue of concern. In 1982, Dillon Reservoir was studied as part of the USEPA's Clean Lakes program (Lewis and others, 1983). The study indicated that the reservoir was mesotrophic (moderate organic production, moderate nutrients); previous studies indicated that the reservoir was oligotrophic (poor organic production, few nutrients) (Northwest Colorado Council of Governments, 2012). Production is the amount of new organic material formed over a period of time, including any losses from respiration, excretion, secretion, injury, death, or grazing during the period (Wetzel, 1983). It was determined that phosphorus loading into the reservoir from multiple sources (including runoff, point sources, septic systems, and construction activities) would need to be controlled to maintain water quality at levels observed in 1982 and protect existing uses over the long term. Because of these concerns, the CDPHE established in 1984 a total phosphorus standard of $0.0074 \mathrm{mg} / \mathrm{L}$ in the top $15 \mathrm{~m}$ of the water column for the growing season (July-October) using 1982 as the reference condition for hydrology (Colorado Department of Public Health and Environment, 2007). This regulation, based on a State-local partnership to control total phosphorus, also established point-source phosphorus load allocations. Most (22 of 24) mean annual concentrations of total phosphorus in the top $15 \mathrm{~m}$ for the growing season during 1984-2007 were less than the regulatory limit of $0.0074 \mathrm{mg} / \mathrm{L}$ (fig. 17). Elevated total phosphorus concentrations in 2002 and 2004, the years that the regulatory limit was exceeded, were likely the result of drought conditions (low reservoir inflow) rather than an increase in total phosphorus from natural and anthropogenic sources (Lewis, 2005).

Lewis (2007) estimated that the total phosphorus load reaching Dillon Reservoir in 2006 from surface inflows was 1,554 kilograms per year $(\mathrm{kg} / \mathrm{yr})$ and from groundwater inflows was $35.4 \mathrm{~kg} / \mathrm{yr}$. Flow-weighted total phosphorus 
Table 12. Summary of the number of samples, minimum, median, and maximum values, and Colorado Department of Public Health and Environment water-quality standards for water-quality samples at Dillon Reservoir near dam (west) (site 135) and Green Mountain Reservoir between Heeney and dam (site 137), Blue River watershed, Colorado.

[No., number; CDPHE, Colorado Department of Public Health and Environment; ${ }^{\circ} \mathrm{C}$, degrees Celsius; ne, no exceedance; $\mathrm{mg} / \mathrm{L}$, milligrams per liter; $\mu \mathrm{S} / \mathrm{cm}$, microsiemens per centimeter at 25 degrees Celsius; --, no standard; m, meter; N, nitrogen; P, phosphorus; $\mu \mathrm{g} / \mathrm{L}$, micrograms per liter. Number after reservoir name refers to site number in Appendix 1 . See figure 5 for location of sites. Water-quality standards are from Colorado Department of Public Health and Environment (2008c, 2008d)]

\begin{tabular}{|c|c|c|c|c|c|c|}
\hline $\begin{array}{l}\text { Property or constituent } \\
\text { (reporting units) }\end{array}$ & $\begin{array}{c}\text { No. of } \\
\text { samples }\end{array}$ & $\begin{array}{l}\text { Minimum } \\
\text { value }\end{array}$ & $\begin{array}{c}\text { Median } \\
\text { value }\end{array}$ & $\begin{array}{l}\text { Maximum } \\
\text { value }\end{array}$ & $\begin{array}{l}\text { CDPHE in-stream } \\
\text { water-quality standard }\end{array}$ & $\begin{array}{l}\text { No. of sampling days } \\
\text { with concentration greater } \\
\text { than water-quality standard }\end{array}$ \\
\hline \multicolumn{7}{|c|}{ Dillon Reservoir near dam (west) (site 135) (1984 through 2007) } \\
\hline \multicolumn{7}{|c|}{ Physical properties } \\
\hline Temperature $\left({ }^{\circ} \mathrm{C}\right)$ & 590 & 0.0 & 6.4 & 17.8 & $\begin{array}{l}\text { Acute: January-March, } 13.0^{\circ} \mathrm{C} ;{ }^{1} \\
\text { Chronic: January-March, } 9.0^{\circ} \mathrm{C} \text {; } \\
\text { Acute: April-December, } 23.8^{\circ} \mathrm{C} \text {; } \\
\text { Chronic: April-December, } 18.2^{\circ} \mathrm{C}\end{array}$ & ne \\
\hline Oxygen, dissolved (mg/L) & 3,003 & 1.4 & 7.2 & 10.4 & ${ }^{2} 6.0$ & $\begin{array}{l}18 \text { sampling days (2002-2007, } \\
\text { July, Aug, Sept, and(or) Oct) }\end{array}$ \\
\hline Specific conductance $(\mu \mathrm{S} / \mathrm{cm})$ & 2,592 & 115 & 228 & 553 & -- & $-\log ^{-}$ \\
\hline Transparency, Secchi disk (m) & 274 & 1.1 & 3.4 & 11.0 & -- & -- \\
\hline \multicolumn{7}{|c|}{ Suspended sediment } \\
\hline Suspended sediment (mg/L) & 2,475 & 0.01 & 1.2 & 9.7 & -- & -- \\
\hline \multicolumn{7}{|c|}{ Nutrients } \\
\hline Nitrate, dissolved (mg/L as N) & 3,045 & 0.001 & 0.160 & 0.430 & 10 & ne \\
\hline Phosphorus, total (mg/L as P) & 3,050 & 0.002 & 0.005 & 0.106 & ${ }^{3} 0.0074$ & ${ }^{4} 2$ \\
\hline Phosphorus, dissolved (mg/L as P) & 3,066 & 0.0004 & 0.002 & 0.104 & -- & -- \\
\hline Phosphorus, particulate (mg/L as $\mathrm{P}$ ) & 3,118 & 0.0003 & 0.003 & 0.023 & -- & -- \\
\hline Orthophosphate (mg/L as P) & 2,966 & 0.0001 & 0.0006 & 0.099 & -- & -- \\
\hline \multicolumn{7}{|c|}{ Algae } \\
\hline$\overline{\text { Chlorophyll- } a(\mu \mathrm{g} / \mathrm{L})}$ & 3,099 & 0.0 & 2.4 & 19.7 & -- & -- \\
\hline
\end{tabular}


Table 12. Summary of the number of samples, minimum, median, and maximum values, and Colorado Department of Public Health and Environment water-quality standards for water-quality samples at Dillon Reservoir near dam (west) (site 135) and Green Mountain Reservoir between Heeney and dam (site 137), Blue River watershed, Colorado.-Continued

[No., number; CDPHE, Colorado Department of Public Health and Environment; ${ }^{\circ} \mathrm{C}$, degrees Celsius; ne, no exceedance; $\mathrm{mg} / \mathrm{L}$, milligrams per liter; $\mu \mathrm{S} / \mathrm{cm}$, microsiemens per centimeter at 25 degrees Celsius; --, no standard; m, meter; N, nitrogen; P, phosphorus; $\mu \mathrm{g} / \mathrm{L}$, micrograms per liter. Number after reservoir name refers to site number in Appendix 1 . See figure 5 for location of sites. Water-quality standards are from Colorado Department of Public Health and Environment (2008c, 2008d)]

\begin{tabular}{|c|c|c|c|c|c|c|}
\hline $\begin{array}{l}\text { Property or constituent } \\
\text { (reporting units) }\end{array}$ & $\begin{array}{c}\text { No. of } \\
\text { samples }\end{array}$ & $\begin{array}{l}\text { Minimum } \\
\text { value }\end{array}$ & $\begin{array}{c}\text { Median } \\
\text { value }\end{array}$ & $\begin{array}{l}\text { Maximum } \\
\text { value }\end{array}$ & $\begin{array}{l}\text { CDPHE in-stream } \\
\text { water-quality standard }\end{array}$ & $\begin{array}{l}\text { No. of sampling days } \\
\text { with concentration greater } \\
\text { than water-quality standard }\end{array}$ \\
\hline \multicolumn{7}{|c|}{ Green Mountain Reservoir between Heeney and dam (site 137) (1984 through 1999, 2005, 2007) } \\
\hline \multicolumn{7}{|c|}{ Physical properties } \\
\hline Temperature $\left({ }^{\circ} \mathrm{C}\right)$ & 286 & 0.7 & 9.1 & 19.0 & $\begin{array}{l}\text { Acute: January-March, } 13.0^{\circ} \mathrm{C} ;{ }^{1} \\
\text { Chronic: January-March, } 9.0^{\circ} \mathrm{C} \text {; } \\
\text { Acute: April-December, } 23.8^{\circ} \mathrm{C} \text {; } \\
\text { Chronic: April-December, } 18.2^{\circ} \mathrm{C}\end{array}$ & 4 (chronic, April-December) \\
\hline Oxygen, dissolved (mg/L) & 1,914 & 0.6 & 7.1 & 12.1 & ${ }^{2} 6.0$ & 6 \\
\hline Specific conductance $(\mu \mathrm{S} / \mathrm{cm})$ & 1,525 & 131 & 189 & 489 & -- & -- \\
\hline Transparency, Secchi disk (m) & 186 & 0.5 & 3.1 & 9.0 & -- & -- \\
\hline \multicolumn{7}{|c|}{ Suspended sediment } \\
\hline Suspended sediment (mg/L) & 2,041 & 0.1 & 2.3 & 34.2 & -- & -- \\
\hline \multicolumn{7}{|c|}{ Nutrients } \\
\hline Nitrate, dissolved $(\mathrm{mg} / \mathrm{L})$ & 2,001 & 0.0003 & 0.129 & 0.392 & 10 & ne \\
\hline Phosphorus, total (mg/L) & 2,024 & 0.002 & 0.008 & 0.042 & -- & -- \\
\hline Phosphorus, dissolved (mg/L) & 2,029 & 0.0008 & 0.004 & 0.015 & -- & -- \\
\hline Phosphorus, particulate $(\mathrm{mg} / \mathrm{L})$ & 2,047 & 0.0009 & 0.004 & 0.034 & -- & -- \\
\hline Orthophosphate $(\mathrm{mg} / \mathrm{L})$ & 2,026 & 0.0001 & 0.001 & 0.011 & -- & -- \\
\hline \multicolumn{7}{|c|}{ Algae } \\
\hline Chlorophyll- $a(\mu \mathrm{g} / \mathrm{L})$ & 1,882 & 0.0 & 1.6 & 16.3 & -- & -- \\
\hline
\end{tabular}

${ }^{1}$ Acute and chronic temperature standards. See Colorado Department of Public Health and Environment (2008c).

${ }^{2}$ Dissolved-oxygen standard applies to the epilimnion and metalimnion strata of lakes and reservoirs (Colorado Department of Public Health and Environment, 2008c).

${ }^{3}$ Total phosphorus standard applies to the top 15 meters of the water column for July through October (the growing season) (Colorado Department of Public Health and Environment, 2008d). The value of $0.0074 \mathrm{mg} / \mathrm{L}$ is the average of the top 15 meters of the water column during the growing season.

${ }^{4}$ Count is the number of years the standard was exceeded. 
concentrations were higher in Soda Creek $(0.0376 \mathrm{mg} / \mathrm{L})$ and effluent from four wastewater treatment plants (ranging from $0.014 \mathrm{mg} / \mathrm{L}$ to $0.0353 \mathrm{mg} / \mathrm{L})$ than the Snake $(0.0059 \mathrm{mg} / \mathrm{L})$ and upper Blue $(0.0061 \mathrm{mg} / \mathrm{L})$ Rivers and Tenmile Creek $(0.0045 \mathrm{mg} / \mathrm{L})$ during 2006 (Lewis, 2007). Because of low discharge, though, total phosphorus loads to Dillon Reservoir from Soda Creek and the wastewater treatment plant effluents were smaller than loads from streams. During 2006, sources of total phosphorus load to Dillon Reservoir from surface water and groundwater included the upper Blue River (33 percent), Tenmile Creek (28 percent), Snake River (22 percent) and Soda Creek (4 percent), other surface-water inflow (11 percent), and groundwater (2 percent) (Lewis, 2007).

Chlorophyll- $a$ concentrations throughout the water column at the dam site (site 135) ranged between 0.0 and $19.7 \mu \mathrm{g} / \mathrm{L}$ from 1984-2007 (table 12). For the 2007 growing season, the median chlorophyll- $a$ concentration in the top $15 \mathrm{~m}$ of the water column was $3.5 \mu \mathrm{g} / \mathrm{L}$. The difference may be because of flow over the spillway of the dam during parts of June, July, and August during 2007 (Lewis, 2008). The median concentration in the top $15 \mathrm{~m}$ during 2007 varied by month, with maximum concentrations ( 4.0 and $4.1 \mu \mathrm{g} / \mathrm{L}$ ) during July and October and a low concentration $(1.6 \mu \mathrm{g} / \mathrm{L})$ during August.

Trophic-state indices for Dillon Reservoir were calculated using total phosphorus, chlorophyll- $a$, and Secchi disk transparency (fig. 18A-C) (Lewis and Saunders, 2002). The trophic index of mean total phosphorus concentration for each year was the time-weighted average concentration of samples collected in the top $15 \mathrm{~m}$ of the water column during May and June. The trophic index of mean chlorophyll- $a$ concentration was the average of samples collected at 0 and $5 \mathrm{~m}$ during July and August of each year; samples were excluded when nitrate was limited (concentration less than $0.010 \mathrm{mg} / \mathrm{L}$ ) because nitrogen limitation may suppress algal growth. The trophic index of mean Secchi disk transparency for each year also was the average for July and August. These month and depth qualifications were determined by Lewis and Saunders (2002) from calibration of a Dillon Reservoir water-quality model. Using trophic-state boundaries for total phosphorus from Lewis and Saunders (2002) and trophic-state boundaries for chlorophyll- $a$ and Secchi disk transparency from Vollenweider and Kerekes (1982), phosphorus data indicated that the trophic status of the reservoir primarily was oligotrophic between 1984 and 2007, whereas chlorophyll- $a$ and Secchi disk transparency data indicated that the trophic status was mesotrophic or mesotrophic/eutrophic, respectively (fig. 18A-C). During 1982, the trophic status of Dillon Reservoir was mesotrophic and was considered adequate to maintain existing uses over time (Colorado Department of Public Health and Environment, 2007). The status is based on total phosphorus concentration and loading and water yield. The calculated trophic status of the reservoir using phosphorus data has been oligotrophic or mesotrophic (one year) since 1984.

Temporal trend analyses were conducted on Secchi disk transparency, dissolved nitrate, total phosphorus, and chlorophyll- $a$ concentrations for the Dillon Reservoir near dam

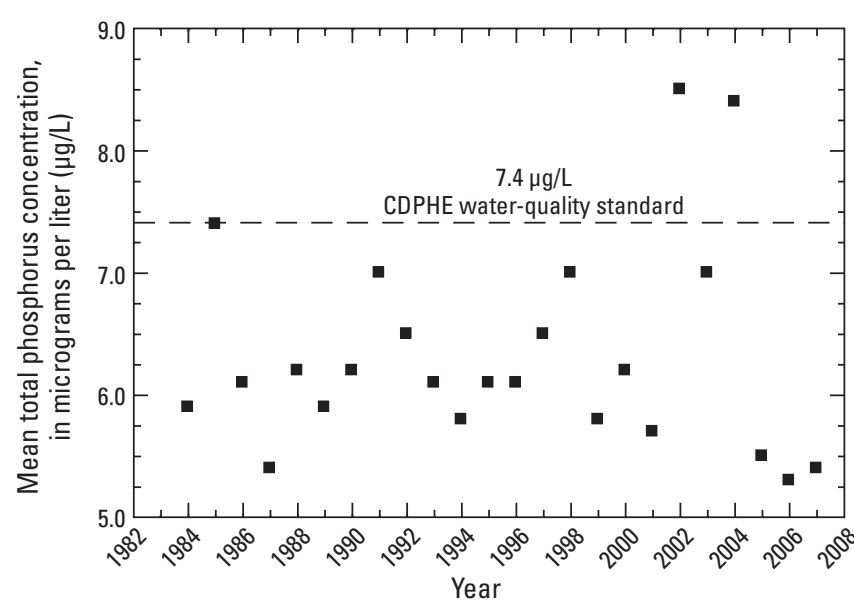

Figure 17. Mean annual growing season (July-0ctober) total phosphorus concentration in the top 15 meters (49.21 feet) of Dillon Reservoir, Dillon Reservoir near dam (west) (site 135), 1984-2007. Data from Lewis (2008). CDPHE, Colorado Department of Public Health and Environment.

site (site 135) for 1984-2007 (table 13). For each constituent, samples collected during the growing season (July-October) from the top $15 \mathrm{~m}$ were analyzed. By selecting similar periods of analysis for each constituent, results for each can be compared. The only statistically significant trend identified was an upward trend in the dissolved nitrate concentration of less than $0.001 \mathrm{mg} / \mathrm{L} /$ year (alpha level 0.05, $\mathrm{p}$-value less than 0.001) (table 13). The trend would have little immediate environmental significance because of the low rate of change and nitrate concentrations were less than or equal to $0.430 \mathrm{mg} / \mathrm{L}$.

No water samples collected at the dam site (site 135) have been analyzed for trace elements. Water samples for trace-element analysis have been collected at five other sites in the reservoir, one site prior to 1982 and four sites during 1997. Water samples were collected at the four sites during 1997 as part of a study investigating water-quality trends in the reservoir using sediment cores; the longest core spanned the sedimentation history of the reservoir (Greve and others, 2001). The study determined that 37 percent of the total water inflow during 1997 and 1998 was contributed by Tenmile Creek, followed by the Blue River (35 percent) and the Snake River (28 percent) (Greve and others, 2001). Tenmile Creek delivered the largest loads of aluminum, barium, and molybdenum. The Blue River delivered less than one-third of any load entering the reservoir, and the Snake River delivered the largest loads of copper, manganese, and zinc (Greve and other, 2001). For water years 1997 and 1998, Greve and others (2001) determined that trace element loads entering Dillon Reservoir were generally larger than those exiting, particularly for copper, iron, and manganese. Even though concentrations of arsenic, cadmium, chromium, copper, lead, and zinc in sediment-core samples exceeded Canadian interim freshwater sediment-quality guidelines, the concentrations in the sediment cores did not adversely affect water quality under limnological conditions in 1997 (Greve and other, 2001). Trace-element 

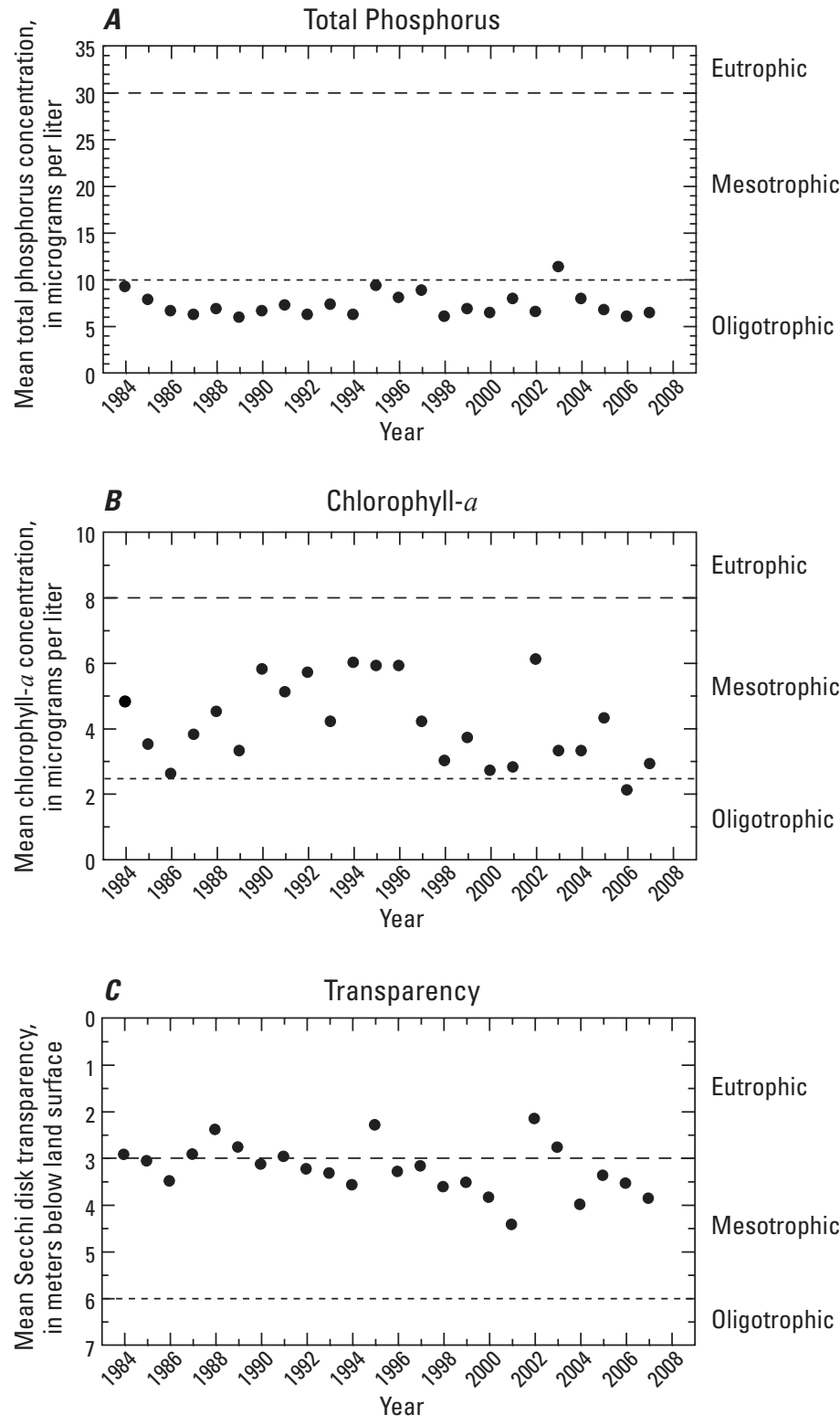

Figure 18. (A) Mean annual total phosphorus and $(B)$ chlorophyll- $a$ concentrations and $(C)$ mean Secchi disk transparency with trophicstate boundaries, Dillon Reservoir near dam (site 135), 1984-2007. Data from Lewis (2008). Trophic-state boundaries from Lewis and Saunders (2002) and Vollenweider and Kerekes (1982).

concentrations in the water column samples met water-quality standards established by the Colorado Department of Public Health and Environment (Greve and other, 2001). The study did identify decreasing concentrations of copper, iron, lithium, nickel, scandium, titanium, and vanadium in sediment over time that may be because of decreased active mining upstream from the reservoir and mine reclamation. A study by Munk and Faure (2004) indicated that the $\mathrm{pH}$ of the water in Dillon Reservoir is the primary environmental variable that controls the concentration of trace elements in the water column. Fluctuations of $\mathrm{pH}$ in the water affect the sorption and desorption of trace elements in the reservoir sediment.

\section{Green Mountain Reservoir}

In Green Mountain Reservoir, nine sites were sampled at least once between August 1975 and November 2007. For five sites, water was collected on five or fewer days. For four sites, Green Mountain Reservoir between Heeney and dam (site 137), Green Mountain Reservoir GA (site 138), Green Mountain Reservoir GB (site 139), and Green Mountain Reservoir GC (site 140), water samples were collected on 165 or more days (table 11). Figure 16 shows time-series plots of water-collection days for these four sites. At Green Mountain Reservoir between Heeney and dam (site 137), water-quality 
Table 13. Results of seasonal Kendall trend analysis for selected water-quality properties and constituents for Dillon Reservoir near dam (west) (site 135), Blue River watershed, Colorado, 1984 through 2007.

[No., number; yr, year; m, meter; na, not applicable; mg/L, milligram per liter; <, less than; $\mu \mathrm{g} / \mathrm{L}$, microgram per liter. Site number after site name refers to figure 5 and Appendix 1]

\begin{tabular}{|c|c|c|c|c|c|c|c|}
\hline $\begin{array}{l}\text { Property or constituent } \\
\text { (reporting units) }\end{array}$ & $\begin{array}{l}\text { Period } \\
\text { of record }\end{array}$ & $\begin{array}{c}\text { No. of } \\
\text { samples }\end{array}$ & $\begin{array}{c}\text { Flow } \\
\text { adjustment }\end{array}$ & p-Value & $\begin{array}{l}\text { Direction } \\
\text { of trend }\end{array}$ & $\begin{array}{l}\text { Rate of } \\
\text { change } \\
\text { (unit/yr) }\end{array}$ & $\begin{array}{c}\text { Median } \\
\text { value }\end{array}$ \\
\hline Transparency, Secchi disk (m) & ${ }^{1} 1984-2007$ & 166 & No & 0.06 & None & na & 3.3 \\
\hline Total phosphorus (mg/L) & ${ }^{2} 1984-2007$ & 163 & No & 0.74 & None & na & 0.006 \\
\hline Chlorophyll- $a(\mu \mathrm{g} / \mathrm{L})$ & ${ }^{2} 1984-2007$ & 164 & No & 0.06 & None & na & 4.5 \\
\hline
\end{tabular}

${ }^{1}$ July through October samples.

${ }^{2}$ July through October samples, 0 - to 15 -meter depth.

samples were collected at the top of the water column and every $5 \mathrm{~m}$ with depth on all 209 sampling days. At sites Green Mountain Reservoir GA (site 138), Green Mountain Reservoir GB (site 139), and Green Mountain Reservoir GC (site 140), water-quality samples were collected at the top and bottom of the water column for 24-26 sampling days and at the top only for the remaining sampling days. The remainder of the discussion in this section is focused on Green Mountain Reservoir between Heeney and dam (site 137). For this site, samples were collected during most years between 1984 and 1999, and again during 2005 and 2007 (fig. 16). Water-temperature data only were available for 2005 and 2007. A summary of selected waterquality data for Green Mountain Reservoir is given in table 12.

Water temperature in Green Mountain Reservoir ranged between 0.7 and $19.0^{\circ} \mathrm{C}$ (table 12) and varied seasonally. Median temperature was at a minimum in March $\left(2.9^{\circ} \mathrm{C}\right)$ and at a maximum in September $\left(12.7^{\circ} \mathrm{C}\right)$. Thermal stratification was similar to that in Dillon Reservoir, typically beginning in May and mixing in fall, but was less well defined because of water withdrawal (Lewis, 2007). Measurements made during January through March 2005 and 2007 indicated that stratification occurred during winter. Acute water-quality standards established by the CDPHE for temperature in Green Mountain Reservoir were not exceeded. Temperature in the epilimnion (thermal strata at the top with little change) was greater than $18.2^{\circ} \mathrm{C}$, the CDPHE chronic water-quality standard for April-December, on 4 of 21 sampling days (August 2005, July and August 2007). These measurements were individual measurements on a particular day and not the maximum weekly average temperature of the mixed layer computed from at least three vertical profiles distributed throughout the growing season (generally July-September), as specified for the chronic standard (Colorado Department of Public Health and Environment, 2008c). The weekly average temperature is determined from a vertical profile of equally spaced temperature measurements separated by not more than $1 \mathrm{~m}$. In Green Mountain Reservoir, temperature was measured every $5 \mathrm{~m}$ for data described in this report.

Dissolved-oxygen concentrations ranged between 0.6 and $12.1 \mathrm{mg} / \mathrm{L}$ (table 12). For samples with temperature data, dissolved oxygen concentrations measured in the epilimnion on six separate days were less than the CDPHE minimum standard of $6.0 \mathrm{mg} / \mathrm{L}$ (Colorado Department of Public Health and Environment, 2008c, 2008d). These concentrations were measured on all four sampling days during August and September 2005 and two sampling days during July and August 2007. For the entire period of record, only two near-bottom concentrations of dissolved oxygen ( 0.63 and $0.79 \mathrm{mg} / \mathrm{L}$ ) measured in June and October 2007 approached anoxic conditions. These values do not violate the CDPHE standard because they were measured in the hypolimnion. Specific conductance values indicated moderate values (median $189 \mu \mathrm{S} / \mathrm{cm}$ ) of dissolved solids in Green Mountain Reservoir (table 12). Except for two values around $489 \mu \mathrm{S} / \mathrm{cm}$, specific conductance was less than or equal to $341 \mu \mathrm{S} / \mathrm{cm}$.

Secchi disk transparency ranged between 0.5 and $9.0 \mathrm{~m}$ below the water surface at site 137 near the dam (table 12). The median transparency of $3.1 \mathrm{~m}$ was slightly lower than the median transparency of $3.2 \mathrm{~m}$ for the southern Rocky Mountains (U.S. Environmental Protection Agency, 2000b). During 2007, transparency was at a minimum $(2.0 \mathrm{~m})$ at the end of May during snowmelt runoff. The maximum transparency of $9.0 \mathrm{~m}$ in Green Mountain Reservoir was less than the maximum transparency in Dillon Reservoir of $11.0 \mathrm{~m}$. Suspendedsediment concentrations for 2,041 samples ranged from 0.1 to $34.2 \mathrm{mg} / \mathrm{L}$ for the index site. Median suspended-sediment concentration in Green Mountain Reservoir was at a minimum $(1.0 \mathrm{mg} / \mathrm{L})$ in January and at a maximum $(5.0 \mathrm{mg} / \mathrm{L})$ in May, similar to the pattern for transparency. Thirty-three measurements of suspended-sediment concentration were greater than $9.7 \mathrm{mg} / \mathrm{L}$, the maximum concentration in Dillon Reservoir.

Dissolved nitrate concentrations in Green Mountain Reservoir between Heeney and dam (site 137) ranged between 0.0003 and $0.392 \mathrm{mg} / \mathrm{L}$ throughout the water column (table 12). Median concentrations during 2007 in the top $15 \mathrm{~m}$ of the water column decreased from a maximum $(0.227 \mathrm{mg} / \mathrm{L})$ in March to a minimum $(0.112 \mathrm{mg} / \mathrm{L})$ in September. As was the case with Dillon Reservoir, nutrient limitation in Green Mountain Reservoir can alternate between nitrogen and phosphorus limitation during summer stratification (Lewis and others, 1984). Nitrogen concentrations in the top $5 \mathrm{~m}$ of the water column were less than $0.010 \mathrm{mg} / \mathrm{L}$ only during late summer (August or September) 1987, 1991, and 1992, indicating possible nitrogen limitation during these times. 
During 2007, more than two-thirds of the nitrate load entering Green Mountain Reservoir came from Dillon Reservoir outflow. The remaining nitrate load came from tributaries and effluent sources between the two reservoirs. These loads were calculated from nitrate concentrations and streamflow data collected during 2007 at sites 113 (Blue River at inlet to Green Mountain Reservoir) and 118 (Blue River below Dillon, CO).

Total phosphorus concentrations at site 137 ranged between 0.002 and $0.042 \mathrm{mg} / \mathrm{L}$ (table 12) for 1984-2007. A water-quality standard for total phosphorus has not been established for Green Mountain Reservoir. The median concentration of $0.008 \mathrm{mg} / \mathrm{L}$ was less than the reference concentration of $0.015 \mathrm{mg} / \mathrm{L}$ for total phosphorus in lakes and reservoirs in the southern Rocky Mountains (U.S. Environmental Protection Agency, 2000b). Median concentrations during 2007 in the top $15 \mathrm{~m}$ of the water column were at a maximum $(0.011 \mathrm{mg} / \mathrm{L})$ during July and at a minimum in February $(0.005 \mathrm{mg} / \mathrm{L})$. During 2007, the median concentration of total phosphorus $(0.007 \mathrm{mg} / \mathrm{L})$ in Green Mountain Reservoir was slightly greater than the median concentration in Dillon Reservoir $(0.005 \mathrm{mg} / \mathrm{L})$. Some of the increase in phosphorus in Green Mountain Reservoir may be from development in the Silverthorne area and downstream to Green Mountain Reservoir, phosphorus flowing out from Straight Creek, and phosphorus from effluent. During 2007, 4.5 percent of the total phosphorus load to Green Mountain Reservoir came from Straight Creek, 3.6 percent from Silverthorne/Dillon effluent, 27.2 percent from Dillon Reservoir outflow, and 64.7 percent from the Blue River drainage between Dillon Reservoir and Green Mountain Reservoir (Lewis, 2008). During 2007, the total phosphorus load entering Green Mountain Reservoir was greater than the load exiting the reservoir (Lewis, 2008).

Chlorophyll- $a$ concentrations throughout the water column at the Green Mountain Reservoir site (site 137) near the dam ranged between 0.0 and $16.3 \mu \mathrm{g} / \mathrm{L}$ for the sampling period (table 12). The median concentration in the top $15 \mathrm{~m}$ of the water column for the 2007 growing season was $2.1 \mu \mathrm{g} / \mathrm{L}$, lower than the median chlorophyll- $a$ concentration of $2.5 \mu \mathrm{g} / \mathrm{L}$ for 1984-1999, and lower than the 2007 median concentration of $3.5 \mu \mathrm{g} / \mathrm{L}$ for Dillon Reservoir. The median concentration for Green Mountain Reservoir increased each month of the growing season during 2007. The difference between the two reservoirs may be because of hydraulic retention time. A shorter retention time for Green Mountain Reservoir has been found to be the most significant factor controlling algae growth in the reservoir (Northwest Colorado Council of Governments, 2012).

Trophic-state indices for total phosphorus, chlorophyll- $a$, and Secchi disk transparency were used to assess the trophic status of Green Mountain Reservoir (fig. 19A-C). The trophic index of mean total phosphorus concentration for each year was the time-weighted average concentration of samples collected in the top $15 \mathrm{~m}$ of the water column during May and June. The trophic index of mean chlorophyll- $a$ concentration for each year was the average of samples collected at 0 and $5 \mathrm{~m}$ during July and August; samples were excluded when nitrate was limited (concentration less than $0.010 \mathrm{mg} / \mathrm{L}$ ). The trophic index of mean Secchi disk transparency for each year was the average for July and August. Using trophic-state boundaries for total phosphorus from Lewis and Saunders (2002) and trophic-state boundaries for chlorophyll- $a$ and Secchi disk transparency from Vollenweider and Kerekes (1982), phosphorus data indicated that the trophic status of Green Mountain Reservoir was mesotrophic except for 2007 when the reservoir was oligotrophic. Chlorophyll- $a$ data indicated that the trophic status was oligotrophic to eutrophic between 1984 and 1993 and was on the oligotrophic/ mesotrophic boundary since 1996. Data for Secchi disk transparency indicated that the trophic status was eutrophic and mesotrophic (fig. 19A-C). Green Mountain Reservoir was more enriched with total phosphorus than Dillon Reservoir for similar sample years and contained less chlorophyll- $a$ beginning in 1993. Chlorophyll- $a$ concentrations typically are limited in Green Mountain Reservoir because of the short residence time of water.

\section{Groundwater Quality}

Data for physical properties, major ions, nutrients, trace elements, and coliform bacteria for groundwater were retrieved from the Blue River watershed water-quality database for 1,234 domestic-drinking water and monitoring wells and 1,952 samples collected from May 1996 through September 2004 (table 14). Only one or two samples were collected from most wells. Almost all (97 percent) wells were sampled as part of a Summit County Environmental Health Department (SCEHD) study on total nitrate concentrations in domestic drinking-water wells in the Blue River watershed (Dan Hendershott, Summit County Environmental Health Department, written commun., 2006). These wells were along the Blue and lower Swan Rivers upstream from Dillon Reservoir, in Breckenridge, Frisco, and Silverthorne and in two areas between Silverthorne and Green Mountain Reservoir. Most (88 percent) well samples only have data for total nitrate; all were collected by SCEHD. Data for physical properties, major ions, nutrients other than total nitrate, and trace elements were available for groundwater samples collected by Adrian Brown Consultants, Inc., in the French Gulch area. Data for the same constituents plus coliform bacteria were available for groundwater samples collected by the USGS in Silverthorne, French Gulch, and others areas upstream from Dillon Reservoir.

Data from all wells were compared to the domestic watersupply standards to provide an overall assessment of existing water-quality conditions in the Blue River watershed, even though only a limited set of groundwater data were available for comparison to the standards for regulatory purposes. Only 4 of 17 wells sampled by the USGS were domestic or publicsupply wells. Three of the four wells were sampled once, and one well was sampled twice. No wells sampled by Adrian 

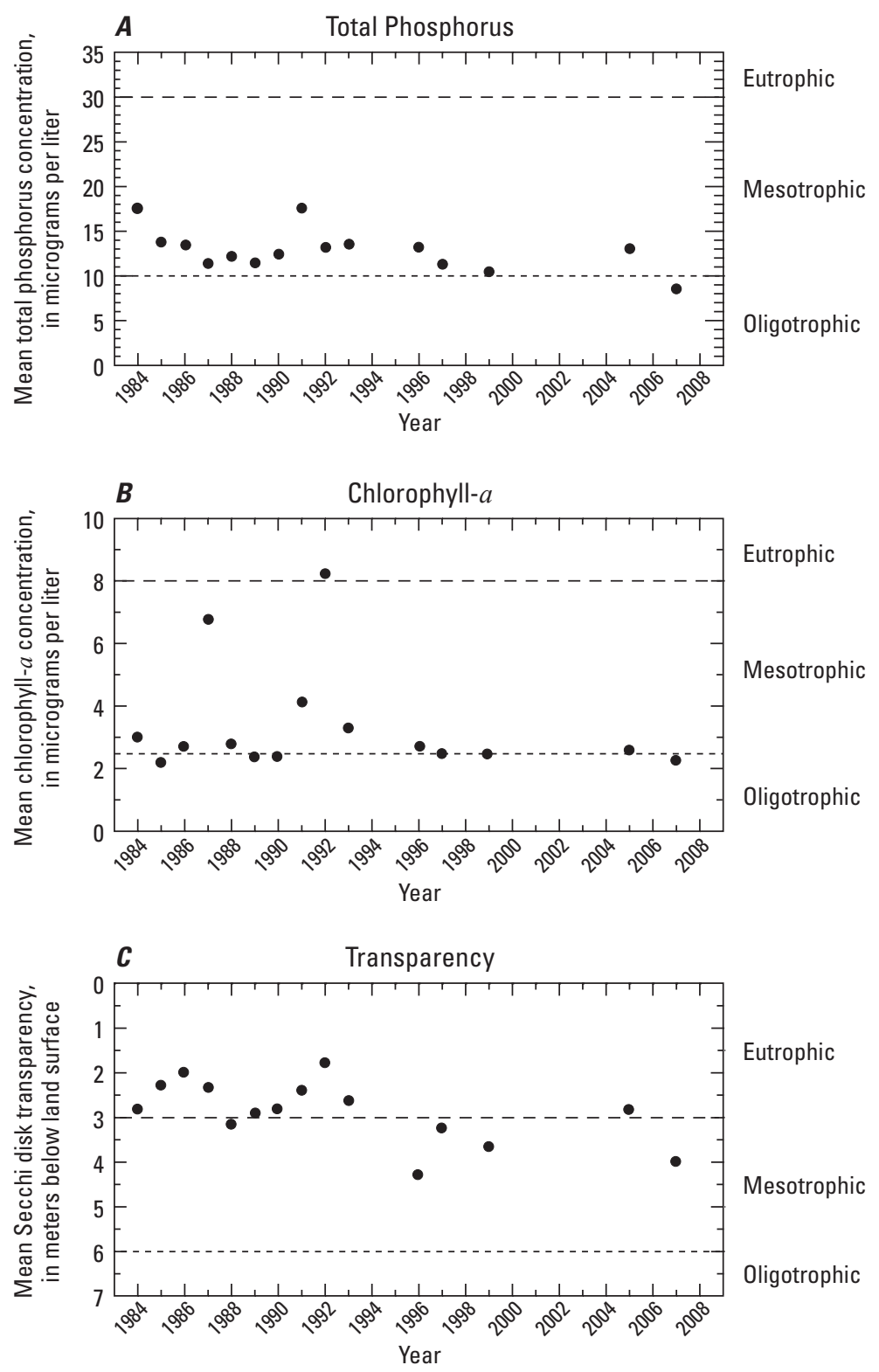

Figure 19. (A) Mean annual total phosphorus and (B) chlorophyll- $a$ concentrations and $(C)$ mean Secchi disk transparency with trophic-state boundaries, Green Mountain Reservoir between Henney and dam (site 137), 1984-2007. Trophic-state boundaries from Lewis and Saunders (2002) and Vollenweider and Kerekes (1982).

Brown Consultants, Inc., were domestic wells. A summary of selected physical properties, major ions, nutrients, trace elements, and coliform bacteria is shown in table 15, along with applicable domestic water-supply standards.

Data for dissolved nitrite and dissolved nitrate were available for 27 and 12 well samples, respectively, collected by Adrian Brown Consultants, Inc., and the USGS during 1997-99 and 2004. Most concentrations were well below CDPHE domestic water-supply standards (table 15). Concentrations of dissolved nitrate plus nitrite were greater than $1.0 \mathrm{mg} / \mathrm{L}$ in seven samples collected by the USGS during 1997 from four monitoring wells in Silverthorne and one domestic water-supply well in Frisco. The concentration in one Silverthorne well was greater than $10 \mathrm{mg} / \mathrm{L}$, the CDPHE domestic water-supply standard for human health. Most total nitrate concentrations in groundwater samples collected from domestic wells by the SCEHD were less than $0.5 \mathrm{mg} / \mathrm{L}$. All but four samples were from the upper Blue River subwatershed and the Tenmile Creek subwatershed.

Total nitrate data for the SCEHD wells were split into six location groups for comparison to total and dissolved nitrate data for streams and dissolved nitrate for reservoirs. The six location groups are Montezuma, upper Blue River subwatershed, Frisco, Silverthorne, Silverthorne to Green 
Table 14. Number of wells and groundwater samples with water-quality data by constitutent group, Blue River watershed, Colorado, 1996 through 2004.

\begin{tabular}{lrc}
\hline \multicolumn{1}{c}{ Constituent group } & $\begin{array}{c}\text { Number } \\
\text { of wells }\end{array}$ & $\begin{array}{c}\text { Number of } \\
\text { samples }^{\mathbf{1}}\end{array}$ \\
\hline Physical properties & 43 & 228 \\
Major ions & 43 & 123 \\
Nutrients & 1,221 & 1,768 \\
Trace elements & 43 & 122 \\
Coliform bacteria & 9 & 13 \\
Total unique wells and samples & ${ }^{2} 1,234$ & ${ }^{2} 1,952$ \\
\hline
\end{tabular}

${ }^{1}$ Excludes 6 well sites and 502 samples with depth to water data only.

${ }^{2} 1,191$ wells and 1,721 samples only have data for total (unfiltered) nitrate.

Mountain Reservoir inlet, and Green Mountain Reservoir inlet. Concentrations of total nitrate generally were higher in groundwater in the Montezuma, Frisco, and Silverthorne areas and the upper Blue River subwatershed than total and dissolved nitrate concentrations in nearby streams. From 1996 through 2002, total nitrate concentrations greater than $0.7 \mathrm{mg} / \mathrm{L}$ were detected in 111 of 1,482 groundwater samples collected in these four location groups. Most total and dissolved nitrate concentrations in streams in the four location groups were less than $0.7 \mathrm{mg} / \mathrm{L}$ for 1996-2002. Exceptions were elevated dissolved nitrate concentrations in Soda Creek downstream from a wastewater treatment plant in the Snake River subwatershed and one sample from the Blue River near Dillon. Some of this difference may be because nitrate data for groundwater were only available for total (dissolved and particulate) concentrations, and some of the stream data were for dissolved concentrations. Nitrate also may be higher in groundwater samples because of seepage from septic systems. During 1999, about 40 percent $(n=19)$ of domestic wells sampled had isotopic nitrogen $\left(\delta^{15} \mathrm{~N}\right)$ values in the range commonly reported for sewage (Kaushal and others, 2006). Over time, some households with septic systems have been added to the municipal wastewater treatment system. Only in the area downstream from Silverthorne to the Green Mountain Reservoir inlet were total nitrate concentrations in groundwater similar to those in streams. Many nitrate concentrations in groundwater samples from the Frisco, the upper Blue River subwatershed, Silverthorne, and Silverthorne to Green Mountain Reservoir areas were higher than concentrations in the two reservoirs. Consumption of nitrate by aquatic biota in reservoirs may account for some of the differences in concentration levels in groundwater and reservoirs.

Major-ion and trace-element data for four samples collected by the USGS during 1997 from four domestic or public water-supply wells were compared to CDPHE domestic watersupply standards. No exceedances for dissolved chloride, fluoride, sulfate, and 16 trace elements were detected (table 15). Remaining USGS samples and all American Geological Services and Adrian Brown Consultants, Inc., samples were collected from 39 monitoring wells during 1996-2000 and 2004. Most (31) wells were in the French Gulch area, 7 of which were sampled as many as 11 times during 1999. Majorion and trace-element concentrations were elevated in many samples, especially those collected in the French Gulch area. Median sulfate and median manganese concentrations, for example, were 1,630 mg/L and 32,000 $\mu \mathrm{g} / \mathrm{L}$, respectively. Wells in the French Gulch area were located in highly mineralized bedrock where historical mining occurred.

\section{Synthesis of Water Quality in the Blue River Watershed}

Analysis of data indicates that overall water quality is good and meets water-quality standards in the Blue River watershed except for specific instances of elevated concentrations of dissolved constituents and nutrients, and low $\mathrm{pH}$ and elevated trace-element concentrations in particular areas. CDPHE water-quality standards for protection of aquatic life were always or mostly met for temperature, dissolved oxygen, chloride, total ammonia, nitrite, various trace elements, and E. coli in streams, reservoirs, and groundwater, where applicable.

In particular areas, water quality has been affected by geologic conditions (sedimentary rocks and mineralized bedrock), urban development, and historical hard-rock mining. High values of dissolved constituents, acid-neutralizing capacity, and hardness can occur from the weathering of sedimentary rocks. Runoff from developed lands and septic and wastewater systems can affect nutrient concentrations and sediment loading in water bodies. Low values of $\mathrm{pH}$ and high concentrations of trace elements such as aluminum, cadmium, copper, iron, manganese, and zinc in water can occur naturally from the weathering of mineralized rocks and anthropogenically from acidic mine drainage. Because of these factors, water quality in the Snake River, upper Blue River, and Tenmile Creek subwatersheds and the lower Blue River watershed can have unique characteristics.

In the Blue River watershed upstream from Dillon Reservoir, specific conductance and dissolved constituents in stream water are affected by rock types in the three subwatersheds. Many of the metals previously mined in the Snake River, upper Blue River, and Tenmile Creek subwatersheds are found in sulfide-replacement orebodies with sulfidebearing minerals such as pyrite and sphalerite. Sedimentary rocks also are present in upper Blue River and Tenmile Creek subwatersheds - limestone and Pierre Shale in the upper Blue River subwatershed and the Minturn and Maroon Formations in the Tenmile Creek subwatershed. Specific conductance values less than $300 \mu \mathrm{S} / \mathrm{cm}$ were more common in the Snake and upper Blue River subwatersheds than the Tenmile Creek subwatershed (fig. 6). Almost one-half of the specific conductance values in the Snake River subwatershed were less than $100 \mu \mathrm{S} / \mathrm{cm}$. The specific conductance of stream water in the Snake River and upper Blue River subwatersheds generally was low because the aluminosilicate minerals present in the igneous rocks in these subwatersheds, such as feldspar, biotite, mica, and hornblende, weather more slowly than the 
Table 15. Summary of the number of groundwater samples and wells, minimum, median, and maximum values, and Colorado Department of Public Health and Environment water-quality standards for groundwater, Blue River watershed, Colorado, 1996 through 2004.

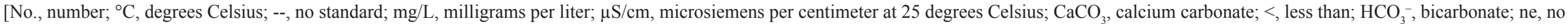
exceedance; $\mathrm{N}$, nitrogen; nc, not computed; P, phosphorus; $\mu \mathrm{g} / \mathrm{L}$, micrograms per liter; col/100 mL, colonies per 100 milliliters. Water-quality standards are from Colorado Department of Public Health and Environment (2009)]

\begin{tabular}{|c|c|c|c|c|c|c|c|c|c|}
\hline \multirow[b]{2}{*}{$\begin{array}{l}\text { Property or constituent } \\
\text { (reporting units) }\end{array}$} & \multirow{2}{*}{$\begin{array}{l}\text { No. of } \\
\text { samples/ } \\
\text { no. of } \\
\text { censored } \\
\text { values }\end{array}$} & \multirow[b]{2}{*}{$\begin{array}{l}\text { No. of } \\
\text { wells }\end{array}$} & \multirow[b]{2}{*}{$\begin{array}{l}\text { Minimum } \\
\text { value }\end{array}$} & \multirow[b]{2}{*}{$\begin{array}{l}\text { Median } \\
\text { value }\end{array}$} & \multirow[b]{2}{*}{$\begin{array}{l}\text { Maximum } \\
\text { value }\end{array}$} & \multicolumn{2}{|c|}{ Domestic water supply } & \multirow{2}{*}{$\begin{array}{c}\text { No. of domestic or } \\
\text { public-supply wells/ } \\
\text { no. samples with } \\
\text { measurement or concentration } \\
\text { for comparison to standard }\end{array}$} & \multirow[b]{2}{*}{$\begin{array}{c}\text { No. of samples } \\
\text { with measurement } \\
\text { or concentration } \\
\text { not meeting } \\
\text { water-quality standard }\end{array}$} \\
\hline & & & & & & $\begin{array}{l}\text { Human } \\
\text { health } \\
\text { standard }^{1}\end{array}$ & $\begin{array}{c}\text { National } \\
\text { secondary } \\
\text { drinking-water } \\
\text { standard }^{2}\end{array}$ & & \\
\hline \multicolumn{10}{|c|}{ Physical properties } \\
\hline Water temperature $\left({ }^{\circ} \mathrm{C}\right)$ & $147 / 0$ & 31 & -0.3 & 9.5 & 17.9 & -- & -- & -- & -- \\
\hline Oxygen, dissolved (mg/L) & $24 / 0$ & 18 & 0.4 & 2.3 & 6.0 & -- & -- & -- & -- \\
\hline Specific conductance $(\mu \mathrm{S} / \mathrm{cm})$ & $119 / 0$ & 31 & 107 & 2,130 & 3,530 & -- & -- & -- & -- \\
\hline $\mathrm{pH}$, field (standard units) & $148 / 0$ & 32 & 4.0 & 6.2 & 12.1 & -- & $6.5-8.5$ & $4 / 5$ & 1 \\
\hline $\begin{array}{l}\text { Acid neutralizing capacity } \\
\quad\left(\mathrm{mg} / \mathrm{L} \text { as } \mathrm{CaCO}_{3}\right)\end{array}$ & $119 / 1$ & 39 & $<2$ & 76 & 443 & -- & -- & -- & -- \\
\hline \multicolumn{10}{|c|}{ Major ions } \\
\hline Bicarbonate, total (mg/L as $\left.\mathrm{HCO}_{3}^{-}\right)$ & $81 / 3$ & 14 & $<2$ & 76 & 230 & -- & -- & -- & -- \\
\hline Calcium, dissolved $(\mathrm{mg} / \mathrm{L})$ & $113 / 0$ & 41 & 11.0 & 302 & 590 & -- & -- & -- & -- \\
\hline Chloride, dissolved (mg/L) & $114 / 8$ & 42 & $<0.05$ & 2 & 143 & -- & 250 & $4 / 4$ & ne \\
\hline Fluoride, dissolved (mg/L & $22 / 0$ & 17 & 0.1 & 0.2 & 1 & 4.0 & -- & $4 / 4$ & ne \\
\hline Magnesium, dissolved (mg/L) & $113 / 2$ & 41 & $<2$ & 100 & 748 & -- & -- & -- & -- \\
\hline Sulfate, dissolved $(\mathrm{mg} / \mathrm{L})$ & $116 / 0$ & 42 & 4 & 1,630 & 7,830 & -- & 250 & $4 / 4$ & ne \\
\hline Dissolved solids $(\mathrm{mg} / \mathrm{L})^{3}$ & $98 / 0$ & 30 & 60 & 2,485 & 10,100 & -- & -- & -- & -- \\
\hline Hardness (mg/L) & $22 / 0$ & 17 & 46 & 115 & 2,500 & -- & -- & -- & -- \\
\hline \multicolumn{10}{|c|}{ Nutrients } \\
\hline Total ammonia (mg/L as N) & $34 / 19$ & 25 & $<0.01$ & $<0.05$ & 0.4 & -- & -- & -- & -- \\
\hline Nitrite, dissolved (mg/L as N) & $27 / 25$ & 17 & $<0.008$ & $\mathrm{nc}^{4}$ & 0.01 & 1.0 & -- & $4 / 4$ & ne \\
\hline Nitrate, dissolved (mg/L as N) & $12 / 0$ & 6 & 0.05 & 0.07 & 0.16 & 10 & -- & $4 / 4$ & ne \\
\hline Nitrate, total $(\mathrm{mg} / \mathrm{L}$ as $\mathrm{N})$ & $1,721 / 0$ & 1,191 & 0 & 0.226 & 2.71 & -- & -- & -- & -- \\
\hline $\begin{array}{l}\text { Nitrate plus nitrite, dissolved } \\
\quad(\mathrm{mg} / \mathrm{L} \text { as } \mathrm{N})\end{array}$ & $27 / 1$ & 17 & $<0.03$ & 0.1 & 10.4 & 10 & -- & $4 / 4$ & $n e^{5}$ \\
\hline $\begin{array}{l}\text { Orthophosphate, dissolved } \\
(\mathrm{mg} / \mathrm{L} \text { as } \mathrm{P})\end{array}$ & $15 / 12$ & 11 & $<0.006$ & $\mathrm{nc}^{4}$ & 0.079 & -- & -- & -- & -- \\
\hline
\end{tabular}


Table 15. Summary of the number of groundwater samples and wells, minimum, median, and maximum values, and Colorado Department of Public Health and Environment water-quality standards for groundwater, Blue River watershed, Colorado, 1996 through 2004. - Continued

[No., number; ${ }^{\circ} \mathrm{C}$, degrees Celsius; --, no standard; mg/L, milligrams per liter; $\mu \mathrm{S} / \mathrm{cm}$, microsiemens per centimeter at 25 degrees $\mathrm{Celsius} \mathrm{CaCO}_{3}$, calcium carbonate; $<$, less than; $\mathrm{HCO}_{3}^{-}$, bicarbonate; ne, no exceedance; N, nitrogen; nc, not computed; P, phosphorus; $\mu \mathrm{g} / \mathrm{L}$, micrograms per liter; col/100 mL, colonies per 100 milliliters. Water-quality standards are from Colorado Department of Public Health and Environment (2009)]

\begin{tabular}{|c|c|c|c|c|c|c|c|c|c|}
\hline \multirow[b]{2}{*}{$\begin{array}{l}\text { Property or constituent } \\
\text { (reporting units) }\end{array}$} & \multirow{2}{*}{$\begin{array}{l}\text { No. of } \\
\text { samples/ } \\
\text { no. of } \\
\text { censored } \\
\text { values } \\
\end{array}$} & \multirow[b]{2}{*}{$\begin{array}{l}\text { No. of } \\
\text { wells }\end{array}$} & \multirow[b]{2}{*}{$\begin{array}{l}\text { Minimum } \\
\text { value }\end{array}$} & \multirow[b]{2}{*}{$\begin{array}{l}\text { Median } \\
\text { value }\end{array}$} & \multirow[b]{2}{*}{$\begin{array}{l}\text { Maximum } \\
\text { value }\end{array}$} & \multicolumn{2}{|c|}{ Domestic water supply } & \multirow{2}{*}{$\begin{array}{c}\text { No. of domestic or } \\
\text { public-supply wells/ } \\
\text { no. samples with } \\
\text { measurement or concentration } \\
\text { for comparison to standard }\end{array}$} & \multirow{2}{*}{$\begin{array}{c}\text { No. of samples } \\
\text { with measurement } \\
\text { or concentration } \\
\text { not meeting } \\
\text { water-quality standard }\end{array}$} \\
\hline & & & & & & $\begin{array}{l}\text { Human } \\
\text { health } \\
\text { standard }^{1}\end{array}$ & $\begin{array}{c}\text { National } \\
\text { secondary } \\
\text { drinking-water } \\
\text { standard }^{2} \\
\end{array}$ & & \\
\hline \multicolumn{10}{|c|}{ Trace elements } \\
\hline Antimony, dissolved $(\mu \mathrm{g} / \mathrm{L})$ & $63 / 48$ & 24 & $<0.1$ & 0.4 & $<3$ & 6 & -- & $4 / 4$ & ne \\
\hline Arsenic, dissolved $(\mu \mathrm{g} / \mathrm{L})$ & $98 / 40$ & 34 & $<0.1$ & 5.8 & 45.2 & 10 & -- & $4 / 4$ & ${ }^{5}$ ne \\
\hline Barium, dissolved $(\mu \mathrm{g} / \mathrm{L})$ & $22 / 0$ & 17 & 2 & 46 & 248 & 2,000 & -- & $4 / 4$ & ne \\
\hline Beryllium, dissolved $(\mu \mathrm{g} / \mathrm{L})$ & $22 / 22$ & 17 & $<0.06$ & $\mathrm{nc}^{4}$ & $<3$ & 4 & -- & $4 / 4$ & ne \\
\hline Cadmium, dissolved $(\mu \mathrm{g} / \mathrm{L})$ & $113 / 28$ & 37 & $<0.04$ & 19.0 & 5,710 & 5 & -- & $4 / 4$ & ${ }^{5}$ ne \\
\hline Chromium, dissolved $(\mu \mathrm{g} / \mathrm{L})$ & $75 / 39$ & 36 & $<0.1$ & 1.0 & ${ }^{6} 10.2$ & 100 & -- & $4 / 4$ & ne \\
\hline Copper, dissolved $(\mu \mathrm{g} / \mathrm{L})$ & $99 / 17$ & 34 & $<0.8$ & 5.0 & 132 & -- & 1,000 & $4 / 4$ & ne \\
\hline Iron, dissolved $(\mu \mathrm{g} / \mathrm{L})$ & $117 / 17$ & 41 & $<3$ & 85,000 & 325,160 & -- & 300 & $4 / 4$ & ne \\
\hline Lead, dissolved $(\mu \mathrm{g} / \mathrm{L})$ & $114 / 49$ & 39 & $<0.08$ & 0.9 & 684 & 50 & -- & $4 / 4$ & ${ }^{5}$ ne \\
\hline Manganese, dissolved ( $\mu \mathrm{g} / \mathrm{L})$ & $113 / 4$ & 39 & $<0.8$ & 32,000 & 167,000 & -- & 50 & $4 / 4$ & ne \\
\hline Molybdenum, dissolved ( $\mu \mathrm{g} / \mathrm{L})$ & $22 / 10$ & 17 & $<0.9$ & 1.0 & 31.9 & 35 & -- & $4 / 4$ & ne \\
\hline Nickel, dissolved $(\mu \mathrm{g} / \mathrm{L})$ & $95 / 26$ & 33 & $<1$ & 100 & 1,185 & 100 & -- & $4 / 4$ & ${ }^{5} \mathrm{ne}$ \\
\hline Selenium, dissolved $(\mu \mathrm{g} / \mathrm{L})$ & $43 / 42$ & 24 & $<0.4$ & $\mathrm{nc}^{4}$ & 3 & 50 & -- & $4 / 4$ & ne \\
\hline Silver, dissolved $(\mu \mathrm{g} / \mathrm{L})$ & $43 / 43$ & 33 & $<0.02$ & $\mathrm{nc}^{4}$ & $<100$ & 50 & -- & $4 / 4$ & ne \\
\hline Thallium, dissolved $(\mu \mathrm{g} / \mathrm{L})$ & $43 / 18$ & 9 & $<0.04$ & 0.34 & 2.5 & 2 & -- & -- & -- \\
\hline Uranium, natural, dissolved $(\mu \mathrm{g} / \mathrm{L})$ & $22 / 14$ & 17 & $<1$ & 1.0 & 7.3 & 30 & -- & $4 / 4$ & ne \\
\hline Zinc, dissolved $(\mu \mathrm{g} / \mathrm{L})$ & $116 / 4$ & 41 & $<0.6$ & 114,450 & $2,010,000$ & -- & 5,000 & $4 / 4$ & ne \\
\hline \multicolumn{10}{|c|}{ Coliform bacteria } \\
\hline Total coliform $(\mathrm{col} / 100 \mathrm{~mL})$ & $13 / 11$ & 9 & $<1$ & $\mathrm{nc}^{4}$ & 5 & ${ }^{7} 23$ & -- & $4 / 4$ & ne \\
\hline
\end{tabular}

${ }^{1}$ Chronic or 30-day standard. See Colorado Department of Public Health and Environment (2009).

${ }^{2}$ Applies to the esthetic quality of a drinking water, such as taste, odor, color, and appearance. See Colorado Department of Public Health and Environment (2009).

${ }^{3}$ Water-quality standard for total dissolved solids depends on background total dissolved-solids concentration. See Colorado Department of Public Health and Environment (2009).

${ }^{4}$ Eighty percent or more of data were censored values. Median value could not be computed.

${ }^{5}$ Value greater than standard was detected in a monitoring well. Water-quality standard only to wells that supply domestic water.

${ }^{6}$ Maximum value does not include one value censored at greater than $50 \mu \mathrm{g} / \mathrm{L}$

${ }^{7}$ Standard is maximum in 30 days. 
carbonate, sulfide, and sulfate minerals present in the sedimentary rocks in the Tenmile Creek subwatershed. Higher specific conductance values (greater than $300 \mu \mathrm{S} / \mathrm{cm}$ ) were measured at some sites in the French Gulch area of the upper Blue River subwatershed where limestone and Pierre Shale were present. Upstream from the confluence with West Tenmile Creek, the Tenmile Creek drainage area is underlain by an extensive section of sedimentary rocks of the Minturn and Maroon Formations (fig. 4). The weathering of these rocks most likely accounts for the high specific conductance values (that is, values greater than $300 \mu \mathrm{S} / \mathrm{cm}$ ) measured at Tenmile Creek sites.

In mineralized and mined areas of the Snake and upper Blue River subwatersheds, the water type primarily was calcium sulfate, reflecting the weathering of sulfate-bearing minerals associated with mineralized lithology and historical mining. In nonmineralized areas and areas downstream from mining, the water type was calcium mixed-sulfatebicarbonate type or calcium bicarbonate because of the inflow of water from streams not affected by mineralization or historical mining. Water type for Tenmile Creek at Frisco was calcium sulfate.

All sulfate and dissolved-solids concentrations in the Snake and upper Blue River subwatersheds were less than the CDPHE domestic water-supply standard for sulfate of $250 \mathrm{mg} / \mathrm{L}$ and the USEPA-recommended concentration for dissolved solids of $500 \mathrm{mg} / \mathrm{L}$. Dissolved sulfate and dissolvedsolids concentrations in the Tenmile Creek subwatershed were elevated in many samples. Dissolved sulfate concentrations were greater than $250 \mathrm{mg} / \mathrm{L}$ in about 8 percent of stream samples from the Tenmile Creek subwatershed for which the standard is applicable. As with specific conductance, elevated dissolved sulfate concentrations probably result from the weathering of sedimentary rocks in the Minturn and Maroon Formations (fig. 4) and also from sulfide minerals in the orebodies of the Climax and Kokomo mining areas (fig. 1). The USEPA-recommended dissolved-solids concentration was exceeded in 28 percent of samples. All exceedances were at Tenmile Creek sites. Hardness values also were elevated in Tenmile Creek. Elevated hardness in some municipal groundwater wells located along Tenmile Creek in the alluvium can affect dishwashing in restaurants and other industrial uses in Frisco.

Nitrogen and phosphorus are essential for plant and animal nutrition, but elevated concentrations in a water body can cause excessive algal and nuisance plant growth (eutrophication). Nutrients (nitrogen and phosphorus) have been issues of concern in the Snake and upper Blue River subwatersheds and the Tenmile Creek subwatershed because they are the main sources of water to Dillon Reservoir, for which a phosphorus control regulation was established in 1984.

Except for samples collected from Soda Creek in the Snake River subwatershed, all nitrate concentrations in the Snake and Blue River subwatersheds and the Tenmile Creek subwatershed were $1.0 \mathrm{mg} / \mathrm{L}$ or less and were well below the CDPHE water-quality standard of $10 \mathrm{mg} / \mathrm{L}$ for domestic water supply. Almost 14 percent of samples for Soda Creek at inlet to weir (site 67) were greater than $10 \mathrm{mg} / \mathrm{L}$. This site is just downstream from a wastewater treatment plant that discharges into a pond at the weir. Effluent is not mixed until it is in Dillon Reservoir. In general, total nitrate concentrations in well samples collected in the Montezuma and Frisco areas and the upper Blue River subwatershed were higher than total and dissolved nitrate concentrations in stream water in the same locations when similar time periods were analyzed.

Median total phosphorus concentrations in the Snake, upper Blue River and Tenmile Creek subwatersheds were less than the median concentration $(0.020 \mathrm{mg} / \mathrm{L})$ for rivers and streams in the southern Rocky Mountains (U.S. Environmental Protection Agency, 2000a). Total phosphorus concentrations in most samples collected in the three subwatersheds were less than USEPA-recommended concentration limits for streams flowing into reservoirs. The recommended total phosphorus concentration limit of $0.05 \mathrm{mg} / \mathrm{L}$ for streams that directly flow into Dillon Reservoir was exceeded in 12 samples from Soda Creek and 6 samples from the Blue River. The recommended concentration limit of $0.1 \mathrm{mg} / \mathrm{L}$ for streams that do not directly flow into Dillon Reservoir was exceeded in six Snake River samples, four West Tenmile Creek samples, and one sample each from Peru Creek and Tenmile Creek. The flowweighted mean concentrations of total phosphorus reaching Dillon Reservoir during 2006 from the Snake and upper Blue Rivers were similar, 0.0059 and $0.0061 \mathrm{mg} / \mathrm{L}$, respectively, and slightly higher than Tenmile Creek, $0.0045 \mathrm{mg} / \mathrm{L}$ (Lewis, 2007). Flow-weighted total phosphorus concentrations were higher in Soda Creek $(0.0376 \mathrm{mg} / \mathrm{L})$ and the effluent from four wastewater treatment plants (ranging from $0.014 \mathrm{mg} / \mathrm{L}$ to $0.0353 \mathrm{mg} / \mathrm{L}$ ) than in the Snake and upper Blue Rivers and Tenmile Creek (Lewis, 2007), but total phosphorus loads to Dillon Reservoir from Soda Creek and the wastewater treatment plant effluents were smaller than loads from streams because of lower discharge. During 2006, it was estimated that the upper Blue River contributed about 33 percent of the total surface water/groundwater phosphorus load to Dillon Reservoir, Tenmile Creek about 28 percent, Snake River about 22 percent, Soda Creek about 4 percent, other surface-water inflow sources about 11 percent, and groundwater inflow about 2 percent (Lewis, 2007). Most of the loading from each subwatershed to Dillon Reservoir occurred during snowmelt runoff (May-July) when suspended-sediment concentrations were highest (Lewis, 2007).

Upstream from Dillon Reservoir, $\mathrm{pH}$ and trace-element concentrations in stream water have been affected by geology (natural geochemical conditions in an area, mineralized bedrock, and sedimentary rocks) and historical hard-rock mining activities. Low values of $\mathrm{pH}$ and elevated concentrations of trace elements such as aluminum, cadmium, copper, iron, manganese, and zinc in water occur naturally from the weathering of mineralized rocks and anthropogenically from acidic mine drainage. Hard-rock mining has occurred in the upper Blue River watershed in areas with mineralized bedrock in the Snake and Blue River subwatersheds and the Tenmile Creek subwatershed, but differences in localized lithology and mine reclamation affect water quality. Values of $\mathrm{pH}$ were less 
than 6.5 in 31 percent of samples measured in the Snake River subwatershed, but acidic drainage in the upper Blue River and Tenmile Creek subwatersheds has been mitigated by the presence of carbonate rocks, and $\mathrm{pH}$ primarily is neutral (7.0) or higher. Increased $\mathrm{pH}$ and alkalinity (which measures the ability of a water sample to neutralize or buffer strong acid) result when calcite in rocks and soils dissolves and releases bicarbonate and carbonate to water (U.S. Environmental Protection Agency, 1997).

Trace-element concentrations were elevated at many stream sites, especially those in the Snake and upper Blue River subwatersheds in and downstream from the mineralized bedrock and mining areas. These areas included the upper Snake River, Peru Creek, Saints John Creek, and the Snake River downstream from the confluence with Peru Creek in the Snake River subwatershed and French Gulch, the Blue River downstream from French Gulch, and Illinois Gulch in the upper Blue River subwatershed. Trace element concentrations also were elevated in groundwater samples collected from wells in the French Gulch area. One or more concentrations of dissolved cadmium, chromium, copper, iron, lead, manganese, nickel, selenium, silver, and zinc and total recoverable iron and total mercury were greater than CDPHE trace-element standards for aquatic-life protection in stream water samples. Exceedances were most common for dissolved zinc, cadmium, copper, and lead, and exceedances were more frequent in the Snake River subwatershed than in the upper Blue River and Tenmile Creek subwatersheds. Exceedances may be less frequent in the Tenmile Creek subwatershed because of the local geology and environmental cleanup in the headwaters of Tenmile Creek. Orebodies in the Snake and upper Blue River subwatersheds and in the Kokomo mining area in the headwaters of Tenmile Creek are sulfide-replacement orebodies whereas the orebody in the Climax mining area, also in the headwaters of Tenmile Creek, is a porphyry molybdenum deposit. In the last 30 years, diversion of clean water around mining-affected areas, water treatment with lime neutralization, and reclamation at the Climax Mine area in the headwaters of Tenmile Creek have resulted in substantial improvements to water quality in Tenmile Creek. Aquatic biota in and downstream from mined areas in the Snake and upper Blue River subwatersheds have been affected by low $\mathrm{pH}$ values and(or) elevated trace-element concentrations. Fish are rare or completely absent in some stream segments, and diversity, population, and community structure of macroinvertebrates change when low $\mathrm{pH}$ and elevated trace-element concentrations occur (Apodaca and others, 2000). Some concentrations of dissolved iron and manganese in stream water greater than domestic water-supply standards may be the result of regional geology.

Temporal trend analysis could not be conducted on stream-water-quality data because statistical requirements (length of data record, censoring of data, and data gaps) for trend analysis were not met. Data used in this analysis of water quality in the Blue River watershed were collected by numerous agencies and entities with different sampling plans and purposes for sample collection. Data were not specifically collected for trend analysis, and limitations in the data that were compiled prevented trend analysis of stream-waterquality data.

Water quality in Dillon Reservoir is affected by inflow of water from the Snake and Blue River and Tenmile Creek subwatersheds and by in-reservoir processes. In-reservoir processes were not specifically addressed in this report. Water-quality data for one site in Dillon Reservoir near the dam (site 135) were analyzed for the study (tables 11 and 12). At this site, data were collected from discrete depths from May 1984 through October 2007. Thermal stratification in the reservoir typically began during May. Mixing occurred during fall, and the reservoir was stratified again during winter. All temperature measurements and most dissolvedoxygen measurements met CDPHE water-quality standards for aquatic-life protection. Anoxic conditions were not detected in the reservoir. There was an inverse relation between transparency in the reservoir and suspended-sediment concentrations. For 1984-2007, median transparency was greatest during April and lowest during May, June, and July, and median suspended-sediment concentrations were lowest during April and at a maximum during May, June, and July. Suspendedsediment concentrations in tributaries to Dillon Reservoir likely were elevated during snowmelt runoff in May and June, and the inflow of this material to the reservoir would increase the amount of suspended material in the reservoir and cause reduced light transmission.

Dissolved nitrate concentrations at the site near the Dillon Reservoir dam were well below the CDPHE domestic water-supply standard of $10 \mathrm{mg} / \mathrm{L}$ (table 12). During 2007, the median dissolved nitrate concentration in the top $15 \mathrm{~m}$ of the water column was highest during May when inflow to the reservoir was greatest and lowest during August, presumably because of phytoplankton consumption of nitrogen. During this time, however, the median chlorophyll- $a$ concentration was lowest during August. The low algal growth may be because of water flowing over the spillway of the dam during parts of June, July, and August. The amount of nitrate in the reservoir presumably has been sufficient to support algal growth since 1994. That was the last year when nitrate concentrations in the top $5 \mathrm{~m}$ of the water column were less than the level at which algal growth may be suppressed. A statistically significant temporal trend was identified for dissolved nitrate for 1984-2007 (table 13). The positive rate of change in concentrations was small, less than 0.001 milligram per liter per year. A major issue of water-quality concern for Dillon Reservoir since the early 1980s has been nutrient enrichment because of phosphorus loading from natural and anthropogenic sources and meeting the CDPHE standard. Between 1984 and 2007, the mean annual total phosphorus concentration in the top $15 \mathrm{~m}$ during the growing season was less than the CDPHE phosphorus standard in all years except 2002 and 2004. The elevated total phosphorus concentrations during these two years were likely related to the lower than normal reservoir inflows that occurred because of drought conditions. The trophic status of Dillon Reservoir during 2007 was estimated to be oligotrophic (low organic production, total 
phosphorus index) and mesotrophic (moderate organic production, transparency and chlorophyll- $a$ indices). Since 1984, the total phosphorus trophic status has been oligotrophic or mesotrophic and considered adequate to maintain existing uses. Nutrient data do not indicate nutrient enrichment (eutrophic conditions) or high organic production in Dillon Reservoir. The median total phosphorus concentration of $0.005 \mathrm{mg} / \mathrm{L}$ in the reservoir was less than the reference condition of $0.015 \mathrm{mg} / \mathrm{L}$ for lakes and reservoirs in the southern Rocky Mountains (U.S. Environmental Protection Agency, 2000b), indicating that Dillon Reservoir is less enriched in total phosphorus than many other lakes and reservoirs in the region. For each subwatershed, at least one-half of the nitrate load into the reservoir occurred during snowmelt runoff (May-July). During 2006, sources of total phosphorus inflow load to Dillon Reservoir included the upper Blue River (33 percent), Tenmile Creek (28 percent), Snake River (22 percent) and Soda Creek (4 percent), other surface-water inflow (11 percent), and groundwater (2 percent) (Lewis, 2007).

Information on trace elements in the reservoir are summarized from a study conducted during 1997 and 1998 that investigated water-quality trends in the reservoir by using sediment cores (Greve and others, 2001). During the study, Tenmile Creek contributed the largest loads of aluminum, barium, and molybdenum to the reservoir; the Blue River contributed less than one-third of any load, and the Snake River contributed the largest loads of copper, manganese, and zinc. During water years 1997 and 1998, trace element loads entering the reservoir were greater than those exiting the reservoir, particularly for copper, iron, and manganese (Greve and others, 2001). Flow of trace elements through the reservoir is indicated by elevated concentrations of some trace elements, such as total recoverable iron and zinc (table 6), at a site just downstream from the reservoir. Canadian freshwater sediment-quality guidelines were exceeded for arsenic, cadmium, chromium, copper, lead, and zinc in reservoir sediment-core samples; but all trace-element concentrations in the reservoir water column met the CDPHE standards.

Water quality in the Blue River downstream from Dillon Reservoir has been affected by localized geology, urban development, outflow from Dillon Reservoir, and tributary inflow. Most temperature and dissolved-oxygen measurements in the lower Blue River watershed met CDPHE water-quality standards for aquatic-life protection. Values that did not meet the standards most commonly were measured before 2002. Specific conductance values less than $300 \mu \mathrm{S} / \mathrm{cm}$ were measured in 89 percent of samples, slightly less than the percentages for the Snake and upper Blue River subwatersheds. Median values of specific conductance and hardness and median concentrations of sulfate and dissolved solids generally were higher for Blue River sites than Straight Creek sites. In contrast, chloride and magnesium concentrations tended to be higher in Straight Creek than in the Blue River, which may be because of deicers, including magnesium chloride, that are applied during winter to the interstate highway that is adjacent to Straight Creek. Specific conductance, hardness, and concentrations of dissolved constituents tended to be lower during snowmelt runoff than during months with low streamflow because of the dilution effect of higher streamflow during runoff. All chloride, sulfate, and dissolved-solids concentrations met the CDPHE domestic water-supply standards for the ions and met a USEPA-recommended concentration for dissolved solids. Data for only 14 samples could be used to classify water type; the primary water type in the lower Blue River watershed was calcium sulfate.

All nitrate concentrations in the lower Blue River watershed were well below the CDPHE domestic water-supply standard; the maximum concentration was $0.672 \mathrm{mg} / \mathrm{L}$. The median nitrate concentration for water flowing out from Dillon Reservoir was greater than the median concentration flowing into Green Mountain Reservoir. Total nitrate data were available for well samples collected downstream from Dillon Reservoir to Green Mountain Reservoir between 1996 and 2002. In general, total nitrate concentrations in these wells were higher than total and dissolved nitrate concentrations in streams in the Silverthorne area and similar to concentrations in streams downstream from Silverthorne when the same time periods were analyzed. One sample from a well in the Silverthorne area had a dissolved nitrate plus nitrite concentration greater than the CDPHE domestic water-supply standard of $10 \mathrm{mg} / \mathrm{L}$.

The total phosphorus concentration in one sample collected during 1999 from the Blue River near where it flows into Green Mountain Reservoir was greater than the USEPArecommended limit $(0.05 \mathrm{mg} / \mathrm{L})$ for streams that directly flow into reservoirs. The concentration in 26 samples, 21 from Straight Creek collected on 11 days as recently as 2003, exceeded the USEPA-recommended limit for streams that do not directly flow into reservoirs. The highest concentrations generally occurred between May and August and reflected the increase in sediment, which phosphorus binds to, when snowmelt runoff and thunderstorm activity were greatest. Unlike nitrate, the median total phosphorus concentration for water flowing out from Dillon Reservoir was less than the median concentration flowing into Green Mountain Reservoir. Increased runoff of phosphorus from urban development in the Silverthorne area may account for some of the enrichment of phosphorus in the Blue River between the two reservoirs.

Downstream from Dillon Reservoir, $\mathrm{pH}$ and traceelement concentrations in stream water have been affected by local geology and mining upstream from Dillon Reservoir. All but six $\mathrm{pH}$ values met the CDPHE water-quality standard for aquatic-life protection. All values that did not meet the standard were greater than 9.0; acidic conditions were not measured. Large-scale hard-rock mining did not occur in the lower Blue River watershed because of the absence of sulfide-rich ore deposits, which reduces the possibility of acidic drainage in streams. With the absence of mining, most or all concentrations of many trace elements were less than laboratory reporting levels, including dissolved cadmium, copper, and lead that were frequently detected in areas upstream from Dillon Reservoir. Dissolved manganese and zinc also were detected 
less frequently downstream from Dillon Reservoir. Elevated concentrations of dissolved manganese and zinc, however, at a site just downstream from Dillon Reservoir indicate that the mining-affected areas upstream from Dillon Reservoir are one possible source for trace elements detected in the river downstream from the reservoir. CDPHE trace-element standards for aquatic-life protection were exceeded in 3.8 percent of the samples collected, similar to the Tenmile Creek subwatershed. Concentrations of dissolved cadmium, copper, lead, and zinc and total recoverable iron rarely exceeded aquatic-life standards. The domestic water-supply standard for manganese was exceeded in only 3 of 269 samples.

Water quality in Green Mountain Reservoir is affected by the inflow of water from the Blue River and in-reservoir processes. In-reservoir processes were not evaluated in this report. Water-quality data for one site in the reservoir near the dam were analyzed for the study. At this site, data were collected from discrete depths during most years between 1984 and 1999 and again during 2005 and 2007. Thermal stratification was similar to that in Dillon Reservoir but less well defined because of the flow-through nature of the reservoir. All or most temperature and dissolved-oxygen measurements met CDPHE standards. Only two dissolved-oxygen concentrations measured at the bottom of the water column in 2007 approached anoxic conditions. Minimum transparency typically occurred during May when snowmelt runoff and suspended-sediment concentrations were higher than in other months.

Dissolved-nitrate concentrations at the site near the dam met the CDPHE domestic water-supply standard. The median nitrate concentration in the top $15 \mathrm{~m}$ of the water column was lowest during September, presumably because of phytoplankton consumption of nitrogen, as with Dillon Reservoir. Possible nitrogen limitation was indicated during late summer of 1987, 1991, and 1992 when concentrations in the top $5 \mathrm{~m}$ of the water column were less than the level at which algal growth may be suppressed. Green Mountain Reservoir was slightly more enriched in phosphorus during 2007 than Dillon Reservoir, based on median total phosphorus concentrations, but less enriched than other lakes and reservoirs in the southern Rocky Mountains, based on data since 1984. Some of the difference between the two reservoirs may be the particulate phosphorus that flows out from Straight Creek along with sediment from soil erosion and traction sand. Green Mountain Reservoir has been a sink for phosphorus. Chlorophyll- $a$ concentrations in the reservoir typically have been limited by the low hydraulic residence time and shorter time period for growth. A total phosphorus standard for Green Mountain Reservoir has not been established by the CDPHE. During 2007, 4.5 percent of the total phosphorus load to Green Mountain Reservoir came from Straight Creek, 3.6 percent from Silverthorne/Dillon effluent, 27.2 percent from Dillon Reservoir outflow, and 64.7 percent from the Blue River drainage between Dillon Reservoir and Green Mountain Reservoir (Lewis, 2008).

\section{Summary}

In the Blue River watershed in the central Rocky Mountains of Colorado, the water quality of streams, reservoirs, and groundwater has been affected by geologic conditions in the area, historical hard-rock mining, and more recent urban development. With these considerations, the U.S. Geological Survey, in cooperation with the Summit Water Quality Committee, conducted a study to compile water-quality data and assess water-quality conditions in the watershed. Stream, reservoir, and groundwater data from May 1984 through November 2007 were compiled from the U.S. Geological Survey National Water Information System, the U.S. Environmental Protection Agency Storage and Retrieval database, and local sources. Analysis of stream and groundwater data was focused primarily on subsets of data: stream water from October 1995 through December 2006, groundwater from May 1996 through September 2004, and reservoir data from May 1984 through November 2007. Stream, reservoir, and groundwater data were summarized and compared to State of Colorado and Federal in-stream waterquality standards and recommendations.

A total of 251 stream sites were included in the waterquality data analysis. More than one-half (132 of 251) of the sites had five or fewer samples collected from October 1995 through December 2006. Data for the Snake River, upper Blue River, and Tenmile Creek subwatersheds upstream from Dillon Reservoir and the lower Blue River watershed downstream from Dillon Reservoir were analyzed and discussed separately.

For the Snake River subwatershed, water-quality data from 148 stream sites and 1,635 samples were analyzed. Except for limited time periods in 1996 and 2000, water temperature met the Colorado Department of Public Health and Environment (CDPHE) acute water-quality standard for protection of cold-water aquatic life. Almost all dissolved-oxygen concentrations were greater than or equal to 6.0 milligram per liter $(\mathrm{mg} / \mathrm{L})$, the minimum dissolved-oxygen concentration established by the CDPHE for protection of aquatic life. Most specific conductance values were less than 300 microsiemens per centimeter at 25 degrees Celsius (henceforth $\mu \mathrm{S} / \mathrm{cm}$ ). About 31 percent of $\mathrm{pH}$ values were less than 6.5, the typical lower bound of the CDPHE aquatic-life water-quality standard for most streams in the subwatershed. Median $\mathrm{pH}$ values less than 6.2 primarily were measured in Peru Creek and the headwaters of the Snake River. Chloride, sulfate, and dissolvedsolids concentrations met the CDPHE domestic water-supply standards or a USEPA-recommended limit. Total ammonia, un-ionized ammonia, nitrite, and nitrate concentrations were generally well below water-quality standards. Almost all total ammonia and nitrite data were censored (values below laboratory reporting levels). All total ammonia and nitrite concentrations met CDPHE standards for aquatic-life protection. All but one site in the Snake River subwatershed, Soda Creek at inlet to weir, had median nitrate concentrations less than or equal to $0.50 \mathrm{mg} / \mathrm{L}$, well below the CDPHE water-quality standard of $10 \mathrm{mg} / \mathrm{L}$ for domestic water supply. Soda Creek at inlet to 
weir had a median nitrate concentration of $4.5 \mathrm{mg} / \mathrm{L}$. Orthophosphate and most total phosphorus concentrations were low. Median total phosphorus concentrations at all 15 sites with 6 or more samples were less than or equal to $0.03 \mathrm{mg} / \mathrm{L}$. Concentrations of total phosphorus in some samples equaled or exceeded the USEPA-recommended concentration limit $(0.05 \mathrm{mg} / \mathrm{L})$ for streams that flow directly into reservoirs.

Concentrations of dissolved and total recoverable arsenic and dissolved chromium and uranium were low throughout the Snake River subwatershed. With a few exceptions, concentrations of total mercury and dissolved silver also were low. Concentrations of dissolved aluminum, cadmium, copper, iron, lead, manganese, and zinc and total recoverable iron were elevated in areas affected by naturally occurring acidic and metal-enriched drainage and in mined areas, particularly in the headwaters of the upper Snake River and Peru Creek. Iron also was elevated at sites not affected by acidic drainage. Concentrations of dissolved cadmium, copper, lead, manganese, selenium, silver, and zinc, dissolved and total recoverable iron, and total mercury at 66 sites throughout the subwatershed exceeded CDPHE water-quality standards for aquatic-life protection. Exceedances occurred at 75 percent of sites sampled for trace elements and in 64 percent of samples collected. The zinc standard was exceeded at the most sites and in the most samples, followed by cadmium and copper. The manganese domestic water-supply standard was exceeded in 50 percent of samples collected at 28 sites, primarily along the entire main stem of the Snake River.

For the upper Blue River subwatershed, water-quality data from 51 stream sites and 1,200 samples were analyzed. Almost all water temperature values and dissolved-oxygen concentrations met CDPHE water-quality standards for the protection of aquatic life. Most specific conductance values were less than $300 \mu \mathrm{S} / \mathrm{cm}$. Six percent of the $\mathrm{pH}$ values did not meet the CDPHE standard for aquatic-life protection. All chloride, sulfate, and dissolved-solids concentrations were less than CDPHE domestic water-supply standards or a USEPArecommended limit. Total ammonia, un-ionized ammonia, nitrite, and nitrate concentrations were low; most total ammonia and nitrate data were censored values. All total ammonia, nitrite, and nitrate concentrations met the CDPHE aquatic-life or domestic water-supply standards. Orthophosphate and total phosphorus concentrations also were low, although six samples collected from Blue River near Dillon Reservoir before July 2001 were greater than the USEPA-recommended limit to control eutrophication in downstream water bodies.

Concentrations of dissolved arsenic, selenium, and uranium and total mercury generally were low throughout the upper Blue River subwatershed. Dissolved aluminum, chromium, copper, and lead concentrations were higher in mined areas but were still relatively low overall. Concentrations of dissolved cadmium, manganese, and zinc and dissolved and total recoverable iron were elevated in mined areas of French Gulch and downstream sites on French Gulch and the Blue River and in Illinois Gulch. Iron, manganese, and zinc concentrations remained elevated at sites on the Blue River downstream from Dillon Reservoir. Iron also was elevated at sites in the headwaters of the Blue River not affected by historical mining. Concentrations of dissolved cadmium, chromium, copper, lead, manganese, nickel, silver, and zinc and total recoverable iron at 21 sites in the subwatershed exceeded CDPHE standards for aquatic-life protection. Exceedances occurred at about 52 percent of sites sampled for trace elements and in about 35 percent of samples collected. The zinc standard was exceeded at the most sites and in most samples, followed by cadmium. The domestic water-supply standard for dissolved manganese was exceeded at four sites. The standards were exceeded most frequently at mining sites and sites downstream from historical mining that were affected by mine drainage, especially French Gulch, the Blue River downstream from the confluence with French Gulch, and Illinois Gulch. The domestic water-supply standard for dissolved manganese was exceeded at four sites. Trace-element concentrations have affected the abundance of macroinvertebrates and survivability of fish in mining-affected areas of the subwatershed.

In the Tenmile Creek subwatershed, water-quality data collected from 19 sites and 459 samples were analyzed. Most water-temperature measurements and dissolved-oxygen concentrations met CDPHE standards for aquatic-life protection. Median specific conductance values at sites along West Tenmile Creek were generally less than $200 \mu \mathrm{S} / \mathrm{cm}$. In Tenmile Creek downstream from the confluence with West Tenmile Creek, median specific conductance values were greater than $300 \mu \mathrm{S} / \mathrm{cm}$; the highest median value at a Tenmile Creek site was $1,055 \mu \mathrm{S} / \mathrm{cm}$. Large areas of the Tenmile Creek subwatershed upstream from West Tenmile Creek are underlain by sedimentary rocks containing soluble minerals. All but two values of $\mathrm{pH}$ were within the CDPHE standard for protection of aquatic life. Any acidic drainage that might occur from historical mining likely is limited because of neutralization by water from carbonate beds in sedimentary rocks and water treatment and water diversion in mined areas. All chloride concentrations met the CDPHE domestic water-supply standard. The CDPHE domestic water-supply standard for sulfate of $250 \mathrm{mg} / \mathrm{L}$ was exceeded in 8 percent of samples collected from applicable stream reaches. The USEPA-recommended dissolved-solids concentration of $500 \mathrm{mg} / \mathrm{L}$ was exceeded in 28 percent of samples. All exceedances were at Tenmile Creek sites. Hardness values in Tenmile Creek also were higher than in other streams. The median hardness was $272 \mathrm{mg} / \mathrm{L}$ at sites on Tenmile Creek and $84 \mathrm{mg} / \mathrm{L}$ at other sites in the Tenmile Creek subwatershed. Most concentrations of total ammonia, un-ionized ammonia, nitrate, orthophosphate, and total phosphorus were low. All total ammonia, nitrite, and nitrate concentrations met CDPHE aquatic life or domestic watersupply standards. For streams that do not directly flow into reservoirs, the recommended limit of $0.1 \mathrm{mg} / \mathrm{L}$ was exceeded in five samples, four from West Tenmile Creek and one from Ten Mile Creek above Wheeler Junction. 
Concentrations of dissolved and total recoverable arsenic, dissolved chromium, copper, nickel, selenium, and silver, and total mercury typically were low throughout the Tenmile Creek subwatershed. Dissolved aluminum, cadmium, manganese, and zinc concentrations, and dissolved and total recoverable iron concentrations were elevated at some sites. Generally, dissolved manganese and zinc concentrations were much lower in the Tenmile Creek subwatershed than in other areas of the upper Blue River watershed. The highest dissolved uranium concentration $(16 \mu \mathrm{g} / \mathrm{L})$ in the Blue River watershed was detected at a Tenmile Creek site. Concentrations of dissolved cadmium, dissolved lead, and total recoverable iron exceeded CDPHE waterquality standards for aquatic-life protection at five sites in the subwatershed. Exceedances occurred in 4.9 percent of samples collected in the Tenmile Creek subwatershed, which is the lowest occurrence of exceedances for the subwatersheds upstream from Dillon Reservoir. The domestic water-supply standard for manganese was exceeded in 19 Tenmile Creek samples. Engineering projects and land reclamation in mined areas of the Tenmile Creek headwaters have led to substantial improvements to water quality in Tenmile Creek.

In the lower Blue River watershed, water-quality data collected from 33 sites and 1,143 samples were analyzed. Almost all water-temperature measurements and dissolvedoxygen concentrations met the CDPHE standard for aquaticlife protection. Most specific conductance values were less than or equal to $300 \mu \mathrm{S} / \mathrm{cm}$. Almost all $\mathrm{pH}$ values were within the CDPHE standard. Unlike areas in the upper Blue River watershed, sulfide-rich ore deposits are not found in the lower Blue River watershed, reducing the possibility of acidic drainage. All concentrations of chloride, sulfate, and dissolved solids were less than CDPHE domestic water-supply standards or the USEPA-recommended limit. Concentrations of total ammonia, un-ionized ammonia, nitrate, and orthophosphate were low. All total ammonia, nitrite, and nitrate concentrations met CDPHE standards for aquatic-life protection or domestic water supply. The USEPA-recommended total phosphorus concentration of $0.05 \mathrm{mg} / \mathrm{L}$ for streams that directly flow into reservoirs was exceeded in one Blue River sample collected during 1999 at the inlet to Green Mountain Reservoir. The recommended total phosphorus concentration of $0.1 \mathrm{mg} / \mathrm{L}$ for streams that do not directly flow into reservoirs was exceeded in 27 samples collected between 1997 and 2003 from 6 sites; 5 samples from two Blue River sites and 22 samples from four Straight Creek sites.

Most trace-element concentrations in the lower Blue River watershed were less than those upstream from Dillon Reservoir. Concentrations of dissolved aluminum, arsenic, cadmium, chromium, copper, lead, nickel, selenium, and silver and total mercury generally were less than laboratory reporting levels, although elevated concentrations were measured in some samples. Dissolved iron concentrations greater than $80 \mu \mathrm{g} / \mathrm{L}$ were measured in some samples from Cataract, Spruce, Straight, and Slate Creeks, but most dissolved iron concentrations were less than $60 \mu \mathrm{g} / \mathrm{L}$. Total recoverable iron concentrations greater than $100 \mu \mathrm{g} / \mathrm{L}$ were measured in some samples from sites along Rock, Spruce, Straight, and Slate Creeks and Blue River at City Road 1. For both forms of iron, concentrations generally were lowest in the Blue River between Dillon and Green Mountain Reservoirs. Dissolved uranium concentrations were less than or equal to $4.8 \mu \mathrm{g} / \mathrm{L}$. Concentrations of dissolved cadmium, copper, lead, manganese, and zinc and total recoverable iron exceeded waterquality standards in some samples. Exceedances occurred in 3.8 percent of samples collected in the lower Blue subwatershed, similar to the proportion of exceedances in the Tenmile Creek subwatershed but much less than those in the Snake River and upper Blue River subwatersheds. The copper standard was exceeded most frequently, in less than 2 percent of samples, and the chronic standard for total recoverable iron was exceeded at the most (four) sites. The only exceedances of the CDPHE standard for $E$. coli for recreational use of streams in the Blue River watershed occurred in two samples collected at two sites in the lower Blue River watershed. Both samples were collected during 2001.

Water-quality data collected at one site in Dillon Reservoir from 1984 through 2007 were analyzed. Thermal stratification typically began in May, and mixing started in fall. Stratification during winter was indicated by values measured during 2003. Water temperature values met the CDPHE water-quality standard for protection of aquatic life. The CDPHE dissolved-oxygen standard for aquatic life was not met for 18 sampling days in early fall between 2002 and 2007; chronic conditions of low dissolved oxygen were not indicated. Anoxic conditions were not detected. All but one specific conductance value were less than $350 \mu \mathrm{S} / \mathrm{cm}$. Maximum Secchi disk transparency was $11.0 \mathrm{~m}$ below the water surface. Median transparency was greatest during April and lowest during May through July, when suspended material flowed into the reservoir during snowmelt runoff. The maximum nitrate concentration $(0.430 \mathrm{mg} / \mathrm{L})$ was well below the CDPHE domestic water-supply standard of $10 \mathrm{mg} / \mathrm{L}$. The median total phosphorus concentration was $0.005 \mathrm{mg} / \mathrm{L}$. Historically, nutrient enrichment in the reservoir because of phosphorus loading from natural and anthropogenic sources has been a water-quality issue of concern. The mean annual total phosphorus concentration in the top 15 meters during the growing season was less than the CDPHE water-quality standard for all years except 2002 and 2004. Elevated concentrations during 2002 and 2004 are likely the result of drought rather than increases from natural and anthropogenic sources. Chlorophyll- $a$ concentrations throughout the water column at the Dillon Reservoir dam site ranged between 0.0 and $19.7 \mu \mathrm{g} / \mathrm{L}$ from 1984-2007. From 1984 to 2007, the trophic state of the reservoir was estimated to be oligotrophic based on total phosphorus data and mesotrophic or mesotrophic/ eutrophic on the basis of chlorophyll- $a$ and Secchi disk transparency data. The only statistically significant trend identified was an upward trend in the dissolved nitrate concentration of less than $0.001 \mathrm{mg} / \mathrm{L} /$ year. 
Water-quality data collected at one site in Green Mountain Reservoir from most years between 1984 and 1999 and during 2005 and 2007 were analyzed. Thermal stratification typically began in May and mixed in fall. Stratification was indicated for winter. Water temperature in the epilimnion was greater than $18.2^{\circ} \mathrm{C}$, the CDPHE chronic water-quality standard for April-December, on 4 of 21 sampling days (August 2005, July and August 2007). Dissolved-oxygen concentrations ranged between 0.6 and $12.1 \mathrm{mg} / \mathrm{L}$. For samples with temperature data, dissolved oxygen concentrations measured in the epilimnion on six separate days were less than the CDPHE minimum standard of $6.0 \mathrm{mg} / \mathrm{L}$. The maximum transparency of $9.0 \mathrm{~m}$ in Green Mountain Reservoir was less than the maximum transparency in Dillon Reservoir of $11.0 \mathrm{~m}$. Dissolved nitrate concentrations in Green Mountain Reservoir between Heeney and dam ranged from 0.0003 and $0.392 \mathrm{mg} / \mathrm{L}$ throughout the water column. The median total phosphorus concentration of $0.008 \mathrm{mg} / \mathrm{L}$ was less than the reference concentration of $0.015 \mathrm{mg} / \mathrm{L}$ for total phosphorus in lakes and reservoirs in the southern Rocky Mountains. The most significant factor controlling algae growth in the Green Mountain Reservoir has been found to be a short hydraulic retention time. The trophic status of Green Mountain Reservoir during 2007 was oligotrophic based on total phosphorus and chlorophyll- $a$ data and mesotrophic based on Secchi disk transparency. Green Mountain Reservoir was more enriched with total phosphorus than Dillon Reservoir for similar sample years and contained less chlorophyll- $a$ beginning in 1993.

Groundwater water-quality samples collected from 1,234 wells from 1996 through 2004 were analyzed. At most sites, only one or two samples were collected. Almost all wells were sampled as part of a Summit County Environmental Health Department (SCEHD) study on total nitrate in domestic drinking-water wells in the Blue River watershed. One concentration of dissolved nitrate plus nitrite collected from a well in Silverthorne during 1997 was greater than the domestic water-supply standard for human health of $10 \mathrm{mg} / \mathrm{L}$. Most total nitrate concentrations in groundwater samples collected from domestic wells by the SCEHD were less than $0.5 \mathrm{mg} / \mathrm{L}$. Total nitrate concentrations typically were higher in groundwater in the Montezuma, Frisco, and Silverthorne areas and the upper Blue River subwatershed than total and dissolved nitrate concentrations in nearby streams. Only in the area downstream from Silverthorne to the inlet to Green Mountain Reservoir were total nitrate concentrations in groundwater similar to those in streams.

\section{Acknowledgments}

The authors greatly appreciate the assistance of Lane Wyatt of the Summit Water Quality Committee in the production of this report. Technical assistance was provided by Dave Mueller and Bill Battaglin of the USGS. Steve Char and Cory Stephens of the USGS produced the maps presented in this report. Reviews were provided by Doug Druliner, Tammy Ivahnenko, and Tony Ranalli of the USGS.

\section{References Cited}

Allan, J.D., 1996, Stream ecology structure and function of running waters: London, Chapman \& Hall, 388 p.

Anderson, M.S., Lakin, H.W., Beeson, K.C., Smith, F.F., and Thancker, E., 1961, Selenium in agriculture: U.S. Department of Agriculture Handbook No. 200.

Apodaca, L.E., Driver, N.E., and Bails, J.B., 2000, Occurrence, transport, and fate of trace elements, Blue River basin, Summit County, Colorado-An integrated approach: Environmental Geology, v. 39, no. 8, p. 901-913.

Bails, J.B., 1998, Water-quality characteristics and massbalance modeling of the French Gulch drainage, Breckenridge, Colorado: Boulder, University of Colorado, Master's thesis, $97 \mathrm{p}$.

Bauch, N.J., and Spahr, N.E., 1998: Journal of Environmental Quality, v. 27, no. 3, p. 640-655.

Beaty, D.W., Landis, G.P., and Thompson, T.B., 1990, Carbonate-hosted sulfide deposits of the central Colorado mineral belt-Introduction, general discussion, and summary: Economic Geology Monograph 7, p. 1-18.

Belanger, Laura, 2002, Source and effect of acid rock drainage in the Snake River watershed, Summit County, Colorado: Boulder, University of Colorado, Master's thesis, $130 \mathrm{p}$.

Bergendahl, M.H., and Koschmann, A.H., 1971, Ore deposits of the Kokomo-Tenmile district, Colorado: U.S. Geological Survey Professional Paper 652, 53 p.

Bird, D.A., 2003, Characterization of anthropogenic and natural sources of acid rock drainage at the Cinnamon Gulch abandoned mine land inventory site, Summit County, Colorado: Environmental Geology, v. 44, p. 919-932.

Boyer, E.W., McKnight, D.M., Bencala, K.E., Brooks, P.D., Anthony, M.W., Zellweger, G.W., and Harnish, R.E., 1999, Streamflow and water quality characteristics for the Upper Snake River and Deer Creek catchments in Summit County, Colorado, water years 1980 to 1990: Boulder, University of Colorado, Institute of Arctic and Alpine Research Occasional Paper 53, $81 \mathrm{p}$.

Boyer, J.N., Kelble, C.R., Ortner, P.B., and Rudnick, D.T., 2009, Phytoplankton bloom status - Chlorophyll $a$ biomass as an indicator of water quality condition in the southern estuaries of Florida, USA: Ecological Indicators, v. 9, issue 6, supplement, p. S56-S67

Brooks, P.D., McKnight, D.M., and Bencala, K.E., 2001, Annual maxima in $\mathrm{Zn}$ concentrations during spring snowmelt in streams impacted by mine drainage: Environmental Geology, v. 40, p. 1447-1454.

Bureau of Reclamation, 2013, Colorado-Big Thompson Project, accessed April 2013, at http://www.usbr.gov/projects/ Project.jsp?proj_Name=Colorado-Big Thompson Project. 
Calamari, D., and Naeve, H., eds., 1994, Review of pollution in the African aquatic environment: Rome, Food and Agriculture Organization of the United Nations, Committee for Inland Fisheries of Africa Technical Paper, no. 25, 118 p.

Carlson, R.E., and Simpson, J., 1996, A coordinator's guide to volunteer lake monitoring methods: North American Lake Management Society, 96 p.

Colorado Department of Local Affairs, 2008, Population for Colorado counties and municipalities: Colorado Department of Local Affairs, State Demography Office, accessed March 2008, at http://www.dola.state.co.us/dlg/demog/ population/estimates/Table5-06Final.pdf.

Colorado Department of Public Health and Environment, 2007, Water Quality Control Commission Regulation No. 71—Dillon Reservoir control regulation: Colorado Department of Public Health and Environment Water Quality Control Commission, 11 p., accessed September 2008, at http://www.cdphe.state.co.us/regulations/ wqccregs/100271dillonreservoir.pdf.

Colorado Department of Public Health and Environment, 2008a, Status of water quality in Colorado-2008, The update to the 2002, 2004, and 2006 305(b) reports: Colorado Department of Public Health and Environment Water Quality Control Commission, variously paginated, accessed October 2008, at http://www.cdphe.state.co.us/op/wqcc/ Resources/waterstatus_305_b/305bUpdate08.pdf.

Colorado Department of Public Health and Environment, 2008b, Total maximum daily load assessment, Snake River and Peru Creek, Summit County, Colorado: Colorado Department of Public Health and Environment Water Quality Control Commission, 51 p., accessed December 2009, at http://www.cdphe.state.co.us/wq/Assessment/TMDL/tmdls. pdf/Snake_River_TMDL_Draft_final_Submittal_V2.pdf.

Colorado Department of Public Health and Environment, 2008c, Water Quality Control Commission Regulation 31The basic standards and methodologies for surface water: Colorado Department of Public Health and Environment Water Quality Control Commission, 185 p., accessed October 2008, at http://www.cdphe.state.co.us/regulations/ wqccregs/.

Colorado Department of Public Health and Environment, 2008d, Water Quality Control Commission Regulation 33Classification and numeric standards for Upper Colorado River Basin and North Platte River (planning region 12) and Regulation 33 tables: Colorado Department of Public Health and Environment Water Quality Control Commission, 64 p., accessed December 2009, at http://www.cdphe. state.co.us/regulations/wqccregs/index.html.
Colorado Department of Public Health and Environment, 2009, Water Quality Control Commission Regulations 41The basic standards for ground water: Colorado Department of Public Health and Environment Water Quality Control Commission, variously paginated, accessed October 2008, at http://www.cdphe.state.co.us/regulations/wqccregs/ 100241wqccbasicstandardsforgroundwater.pdf.

Colorado Division of Water Resources and Colorado Water Conservation Board, 2008, Colorado's Decision Support Systems - Blue River basin [Water District 36]: Colorado Divsion of Water Resources, accessed June 2008, at http://cdss.state.co.us/DNN/Structures/tabid/75/Default.aspx.

Deacon, J.R., and Mize, S.V., 1997, Effects of water quality and habitat on composition of fish communities in the Upper Colorado River basin, Colorado: U.S. Geological Survey Fact Sheet 122-97, 6 p.

Deacon, J.R., Spahr, N.E., Mize, S.V., and Boulger, R.W., 2001, Using water, bryophytes, and macroinvertebrates to assess trace-element concentrations in the Upper Colorado River basin: Hydrobiologia, v. 455, p. 29-39.

Deacon, J.R., and Stephens, V.C., 1998, Trace elements in streambed sediment and fish liver at selected sites in the Upper Colorado River basin, Colorado, 1995-96: U.S. Geological Survey Water-Resources Investigations Report 98-4124, 19 p.

Dean Runyan Associates, 2010, The economic impact of travel on Colorado 1996-2009: Portland, Oreg., Dean Runyan Associates, $56 \mathrm{p}$.

Denver Water Board, 2008, Dillon Reservoir: Denver Water, accessed March 2008, at http://www.denverwater.org/ recreation/dillon.html.

Dubrovsky, N.M., Burow, K.R., Clark, G.M., Gronberg, J.M., Hamilton P.A., Hitt, K.J., Mueller, D.K., Munn, M.D., Nolan, B.T., Puckett, L.J., Rupert, M.G., Short, T.M., Spahr, N.E., Sprague, L.A., and Wilber, W.G., 2010, The quality of our Nation's waters-Nutrients in the Nation's streams and groundwater, 1992-2004: U.S. Geological Survey Circular 1350, 174 p., accessed February 2014, at: http://pubs.usgs.gov/circ/1350/.

Fey, D.L, Church, S.E., Unruh, D.M., and Bove, D.J., 2002, Water and sediment study of the Snake River watershed, Colorado, Oct. 9-12, 2001: U.S. Geological Survey OpenFile Report 02-0330, 41 p. plus appendixes, accessed May 2008, at http://pubs.usgs.gov/of/2002/ofr-02-0330/ OFR-02-0330.pdf.

Gilliland, M.E., 2006, Summit—A gold rush history of Summit County, Colorado: Silverthorne, Colo., Alpenrose Press, $501 \mathrm{p}$.

GlobalInfoMine, 2008, Climax Molybdenum Mine: GlobalInfoMine, accessed December 2009, at http://technology. infomine.com/articles/1/3616/molybdenum.talings.water/ climax.molybdenum.mine.aspx. 
Green, G.N., 1992, The digital geologic map of Colorado in Arc/Info format: U.S. Geological Survey Open-File Report 92-0507, scale 1:500,000.

Greve, A.I., Spahr, N.E., Van Metre, P.C., and Wilson, J.T., 2001, Identification of water-quality trends using sediment cores from Dillon Reservoir, Summit County, Colorado: U.S. Geological Survey Water-Resources Investigations Report 01-4002, 33 p., accessed February 2008, at http://co.water.usgs.gov/nawqa/ucol/pdf/wrir01-4022.pdf.

Hansen, J.A., Walsh, P.G., Lipton, Josh, Cacela, Dave, and Dailey, A.D., 2002, Relative sensitivity of bull trout (Salvelinus confluentus) and rainbow trout (Oncorhynchus mykiss) to acute exposures of cadmium and zinc: Environmental Toxicology and Chemistry, v. 21, no. 1, p. 67-75.

Helsel, D.R., 2005, Nondetects and data analysis-Statistics for censored environmental data: Hoboken, N.J., John Wiley \& Sons, Inc., $250 \mathrm{p}$.

Helsel, D.R., and Hirsch, R.M., 2002, Statistical methods in water resources: U.S. Geological Survey Techniques of Water-Resources Investigations, book 4, chap. A3, accessed February 2008, at http://pubs.usgs.gov/twri/twri4a3/html/ pdf_new.html.

Hem, J.D., 1992, Study and interpretation of the chemical characteristics of natural waters: U.S. Geological Survey Water-Supply Paper 2254, 263 p., accessed July 2010, at http://pubs.usgs.gov/wsp/wsp2254/html/pdf.html.

Hirsch, R.M., Slack, J.T., and Smith, R.A., 1982, Techniques for trend analysis for monthly water quality data: Water Resources Research, v, 18, p. 107-121.

Kaushal, S.S., Lewis, W.M., Jr., and McCutchan, J.H., Jr., 2006, Land use change and nitrogen enrichment of a Rocky Mountain watershed: Ecological Applications, v. 16, no. 1, p. 299-312.

Kellogg, K.S., Bartos, P.J., and Williams, C.L., 2002, Geologic map of the Frisco quadrangle: U.S. Geological Survey Miscellaneous Field Studies Map MF-2340, accessed April 2008, at http://pubs.usgs.gov/mf/2002/mf-2340/.

Kimball, B.A., McKnight, D.M., Wetherbee, G.A., and Harnish, R.A., 1992, Mechanisms of iron photoreduction in a metal-rich acidic stream (St. Kevin Gulch, Colorado, U.S.A.): Chemical Geology, v. 96, p. 227-239.

Kimball, B.A., Runkel, R.L., and Gerner, L.J., 1999, Quantification of metal loading in French Gulch, Summit County, Colorado, using a tracer-injection study, July 1996: U.S. Geological Survey Water-Resources Investigations Report 98-4078, 20 p.

Koschmann, A.H., and Bergendahl, M.H., 1968, Principal gold producing districts of the United States: U.S. Geological Survey Professional Paper 610, 283 p.
LaMotte, Andrew, 2008, National Land Cover Dataset 2001 (NLCD01) Tile 3, Southwest United States, NLCD01-3: U.S. Geological Survey, [digital data], accessed February 2009, at http://water.usgs.gov/GIS/metadata/usgswrd/XML/ nlcd01_3.xml.

Lemonds, P.J, 2003, Modeling pollution transport and fate to assess the effects of onsite wastewater systems on the Lake Dillon watershed: Golden, Colo., Colorado School of Mines, Master's thesis, $330 \mathrm{p}$.

Lemonds, P.J., and McCray, J.E., 2003, Modeling phosphorus transport in the Blue River watershed, Summit County, Colorado, in Renard, K.G., McElroy, S.A., Gburek, W.J., Canfield, H.E., and Scott, R.L, eds., Proceedings of the first interagency conference on research in watersheds: U.S. Department of Agriculture, Agricultural Research Service, p. 271-277.

Lewis, W.M., Jr., 2005, Lake Dillon monitoring project, 2004 annual report: Silverthorne, Colo., Summit Water Quality Committee, $10 \mathrm{p}$.

Lewis, W.M., Jr., 2007, Lake Dillon monitoring project, 2006 annual report: Silverthorne, Colo., Summit Water Quality Committee, $34 \mathrm{p}$.

Lewis, W.M., Jr., 2008, Green Mountain Reservoir and Lake Dillon monitoring project, 2007 annual report: Silverthorne, Colo., Summit Water Quality Committee, 24 p.

Lewis, W.M., Jr., and Saunders, J.F., 2002, Lake Dillon water quality model, revision and recalibration for 2001: Silverthorne, Colo., Summit Water Quality Committee.

Lewis, W.M., Jr., Saunders. J.F., Crumpacker, D.W., and Brendecke, C., 1983, Clean lake study of Dillon Reservoir in Summit County, Colorado: Silverthorne, Colo., Northwest Colorado Council of Governments, 392 p.

Lewis, W.M., Jr., Saunders, J.F., Crumpacker, D.W., and Brendecke, C, 1984, Eutrophication and land use, Lake Dillon, Colorado: New York, Springer-Verlag, 202 p.

Lovering, T.S., 1934, Geology and ore deposits of the Breckenridge mining district, Colorado: U.S. Geological Survey Professional Paper 176, 64 p.

Mach, C.J., and Thompson, T.B., 1998, Geology and geochemistry of the Kokomo mining district, Colorado: Economic Geology, v. 93, p. 617-638.

Mayer, F.L., Jr., and Ellersieck, M.R., 1986, Manual of acute toxicity-Interpretation and data base for 410 chemicals and 66 species of freshwater animals: U.S. Fish and Wildlife Service Resource Publication 160, 579 p.

McKnight, D.M., and Bencala, K.E., 1989, Reactive iron transport in an acidic stream in Summit County, ColoradoA hydrologic perspective: Geochimica at Cosmochimica Acta, v. 53, no. 9, p. 2225-2234. 
McKnight, D.M., and Bencala, K.E., 1990, The chemistry of iron, aluminum, and dissolved organic materials in three acidic, metal-enriched, mountain streams, as controlled by watershed and in-stream processes: Water Resources Research, v. 26, no. 12, p. 3087-3100.

McKnight, D.M., and Feder, G.L., 1984, The ecological effects of acid conditions and precipitations of hydrous metal-oxides in a Rocky Mountain stream: Hydrobiologia, v. 119 , no. 2, p. 129-138.

Morris, D.P., and Lewis, W.M., Jr., 1988, Phytoplankton nutrient limitation in Colorado mountain lakes: Freshwater Biology, v. 20, p. 315-327.

Mueller, D.K., Hamilton, P.A., Helsel, D.R., Hitt, K.J., and Ruddy, B.C., 1995, Nutrients in groundwater and surface water of the United States-An analysis of data through 1992: U.S. Geological Survey Water-Resources Investigations Report 95-4031, 74 p.

Munk, LeeAnn, and Faure, Gunther, 2004, Effects of pH fluctuations on toxic metals in the water and sediment of the Dillon Reservoir, Summit County, Colorado: Applied Geochemistry, v. 19, p. 1065-1074.

Munk, LeeAnn, Faure, Gunther, Pride, D.E., and Bigham, J.M., 2002, Sorption of trace metals to an aluminum precipitate in a stream receiving acid rock-drainage-Snake River, Summit County, Colorado: Applied Geochemistry, v. 17 , p. $421-430$.

Niyogi, D.K., 1999, Effects of stress from mine drainage on ecosystem functions in Rocky Mountain streams: Boulder, University of Colorado, Ph.D. dissertation, 181 p.

Northern Colorado Water Conservancy District, 2013, Green Mountain Reservoir: Northern Colorado Water Conservancy District, accessed September 2013, at http://www.northernwater.org/WaterProjects/ GreenMountainReservoir.aspx.

Northwest Colorado Council of Governments, 2012, Blue River watershed plan: Silverthorne, Colo., Northwest Colorado Council of Governments, variously paginated, accessed April 2013, at http://www.nwccog.org/index.php/ programs/watershed-services/.

Piatak, N.M., 2000, Sorption of trace elements in acid mine drainage contaminated water-The Snake River, Summit County, Colorado: Columbus, The Ohio State University, Master's thesis, $120 \mathrm{p}$.

PRISM Group and Oregon Climate Service, 2006, Average annual precipitation, 1971-2000, Colorado: Oregon State University, accessed April 2008, at http://prism.oregonstate.edu/ pub/prism/state_ppt/colorado300.png.
Rounds, S.A., 2006, Alkalinity and acid neutralizing capacity: U.S. Geological Survey Techniques of Water Resources Investigations, book 9 [National Field Manual], chap. A6.6, accessed April 2008, at http://water.usgs.gov/owq/ FieldManual/Chapter6/section6.6/.

Schertz, T.L., Alexander, R.B., and Ohe, D.J., 1991, The computer program estimate trend (ESTREND), a system for the detection of trends in water-quality data: U.S. Geological Survey Water-Resources Investigations Report 91-4040, $70 \mathrm{p}$.

Spahr, N.E., Boulger, R.W., and Szmajter, R.J., 2000, Water quality at basic fixed sites in the upper Colorado River basin National Water-Quality Assessment study unit, October 1995-September 1998: U.S. Geological Survey Water Resources Investigations Report 99-4223, 63 p.

Sullivan, A.B., and Drever, J.I., 2001, Spatiotemporal variability in stream chemistry in a high-elevation catchment affected by mine drainage: Journal of Hydrology, v. 252, p. 237-250.

Summit County Government, 2009, Analysis of Summit County economic activity for 2009 reappraisal: Breckenridge, Colo., Summit County Government, Office of the County Assessor, $10 \mathrm{p}$.

TDS Consulting, Inc., 2004, Water-quality assessment-Snake River watershed, Summit County, Colorado: TDS Consulting, Inc., Project no. 0302, 39 p. [Report prepared for Summit Water Quality Committee and Northwest Colorado Council of Governments, final report.]

Theobald, P.K., Jr., Lakin, H.W., and Hawkins, D.B., 1963, The precipitation of aluminum, iron, and manganese at the junction of Deer Creek with the Snake River in Summit County, Colorado: Geochimica et Cosmochimica Acta, v. 27 , no. 2 , p. 121-132.

Todd, A.S., 2005, Mining legacies in the Snake River watershed-The interaction of biogeochemistry, stream ecology, and human use: Boulder, University of Colorado, Ph.D. dissertation, $144 \mathrm{p}$.

Todd, A.S., McKnight, D.M., and Duren, S.M., 2005, Water quality characteristics for the Snake River, North Fork of the Snake River, Peru Creek, and Deer Creek in Summit County, Colorado, 2001 to 2002: Boulder, University of Colorado, Institute of Arctic and Alpine Research Occasional Paper 57, $46 \mathrm{p}$.

Town of Breckenridge, 2008, 2008 Comprehensive Plan: Breckenridge, Colo., Town of Breckenridge, $171 \mathrm{p}$.

Tweto, Ogden, comp., 1979, Geologic map of Colorado: U.S. Geological Survey State Geologic Map, scale 1:500,000.

U.S. Environmental Protection Agency, 1977, STORET user handbook - the right answers for STORET users: U.S. Environmental Protection Agency, Office of Water and Hazardous Materials TD900U56, 604 p. 
U.S. Environmental Protection Agency, 1986, Quality criteria for water, 1986: U.S. Environmental Protection Agency Report 440/5-86-001, variously paginated.

U.S. Environmental Protection Agency, 1997, Volunteer steam monitoring - a methods manual: U.S. Environmental Protection Agency Report 841-B-97-003, 227 p., accessed April 2013, at http://water.epa.gov/type/rsl/monitoring/ upload/2002_08_13_volunteer_stream_stream.pdf.

U.S. Environmental Protection Agency, 2000a, Ambient water quality criteria recommendations, rivers and streams in nutrient Ecoregion II: U.S. Environmental Protection Agency Report 822-B-00-015, 120 p., accessed December 2009, at http://www.epa.gov/waterscience/criteria/ nutrient/ecoregions/rivers/rivers_2.pdf.

U.S. Environmental Protection Agency, 2000b, Ambient water quality criteria recommendations, lakes and reservoirs in nutrient Ecoregion II: U.S. Environmental Protection Agency Report 822-B-00-007, 107 p., accessed December 2009, at http://www.epa.gov/waterscience/criteria/ nutrient/ecoregions/lakes/lakes_2.pdf.

U.S. Environmental Protection Agency, 2008a, Drinking water contaminants: U.S. Environmental Protection Agency, accessed April 2008, at http://www.epa.gov/safewater/ contaminants/index.html.

U.S. Environmental Protection Agency, 2008b, Superfund Program - French Gulch: U.S. Environmental Protection Agency, accessed April 2008, at http://www.epa.gov/ region8/superfund/co/frenchgulch/index.html.

U.S. Environmental Protection Agency, 2012, EPA map of radon zones-Colorado: U.S. Environmental Protection Agency, accessed September 2012, at http://www.epa.gov/ radon/pdfs/statemaps/colorado.pdf.
U.S. Geological Survey, 2013, Toxic Substances Hydrology Program-Bioaccumulation: U.S. Geological Survey, accessed May 2013, at http://toxics.usgs.gov/definitions/ bioaccumulation.html.

U.S. Geological Survey, 2014: The USGS science schoolrunoff: U.S. Geological Survey, access February 2014, at http://water.usgs.gov/edu/runoff.html.

Vollenweider, R.A., and Kerekes, J., 1982, Eutrophication of waters-Monitoring assessment and control: Paris, Organization for Economic Co-operation and Control, Environment Directorate, $154 \mathrm{p}$.

Western Regional Climate Center, 2014, Dillon 1 E, Colorado (052281), Period of record general climate summary - temperature: Western Regional Climate Center, accessed March 2014, at http://www.wrcc.dri.edu/cgi-bin/ cliMAIN.pl?co2281.

Wetzel, R.G., 1983, Limnology: Philadelphia, Pa., W.B. Saunders, 767 p.

White River National Forest, 2008, Copper Mountain Resort, Environmental assessment, Tenmile Creek facilities improvements and reclamation project: USDA Forest Service, White River National Forest, Dillon, Colorado, Ranger District, 161 p., accessed December 2009, at http://www.fs.fed.us/r2/whiteriver/projects/copper/ CopperMtnResortTenmileEA.pdf.

Widmann, B.L., Bartos, P.J., McCalpin, J.P., and Jackson, Jeffrey, 2004, Geologic map of the Copper Mountain quadrangle, Summit, Eagle, Lake, and Park Counties, Colorado: Colorado Geological Survey Open-File Report 03-20, scale 1:24.000. 
Appendixes 

Appendix 1. Stream sites in the Blue River watershed with six or more water-quality samples or exceedances of Colorado Department of Public Health and Environment trace element water-quality standards for protection of aquatic life or domestic water supply and selected reservoir sites.

[USEPA, U.S. Environmental Protection Agency; STORET, STOrage and RETrieval database; USGS, U.S. Geological Survey; NWIS, National Water Information System; HR Inc., Hydrosphere Resource Consultants, Inc.; INSTAAR, University of Colorado Institute of Arctic and Alpine Research; CDPHE, Colorado Department of Public Health and Environment; DOW-RW, Colorado Division of Wildlife River Watch program; AGS, American Geological Services; ABSR, Arapahoe Basin Ski Resort; CSU-FWB, Colorado State University Department of Fish, Wildlife, and Conservation Biology; NWCCOG, Northwest Colorado Council of Governments; SWQC, Summit Water Quality Committee; ABC Inc, Adrian Brown Consultants, Inc.; BSD, Breckenridge Sanitation District; CDOT, Colorado Department of Transportation; DWB, Denver Water Board. USGS streamflow-gaging stations with the listing of 'Active' are operational as of water year 2008 ; stations listed as 'Historic' have been discontinued. See figure 3 for location of active gages. Some stream sites with six or more water-quality samples or exceedances of standards are not listed because no latitude and longitude data were available for the sites]

\begin{tabular}{|c|c|c|c|c|c|c|}
\hline \multirow[b]{2}{*}{$\begin{array}{c}\text { Site } \\
\text { number in } \\
\text { this report } \\
\text { (fig. 5) }\end{array}$} & \multicolumn{6}{|c|}{ Information from USEPA STORET and USGS NWIS } \\
\hline & $\begin{array}{l}\text { Site identification } \\
\text { number in database }\end{array}$ & Site name in database & Latitude & Longitude & Source agency & $\begin{array}{c}\text { USGS } \\
\text { streamflow- } \\
\text { gaging } \\
\text { station }\end{array}$ \\
\hline \multicolumn{7}{|c|}{ Snake River subwatershed } \\
\hline 1 & CCAU02 & Camp Cr autosampler & 393612 & 1055639 & HR Inc. & \\
\hline 2 & CCSW01 & Camp Cr stream grab 1 & 393603 & 1055643 & HR Inc. & \\
\hline 3 & CCSW02 & Camp Cr stream grab 2 & 393612 & 1055639 & HR Inc. & \\
\hline 4 & Cinnamon Gulch & Cinnamon Gulch & 393604 & 1054908 & INSTAAR & \\
\hline 5 & CG-SW-02 & Cinnamon Gulch at toe of waste rock pile & 393515.432 & 1054852.488 & USEPA & \\
\hline 6 & CG-SW-03 & Cinnamon Gulch below mines and before wetlands & 393528.535 & 1054849.752 & USEPA & \\
\hline 7 & 12348 & Deer $\mathrm{Cr}$ abv Montezuma at mouth & 393349 & 1055138 & CDPHE & \\
\hline 8 & JGAU02 & Jones Gulch autosampler & 393533 & 1055543 & HR Inc. & \\
\hline 9 & JGSW01 & Jones Gulch stream grab 1 & 393448 & 1055534 & HR Inc. & \\
\hline 10 & JGSW02 & Jones Gulch stream grab 2 & 393533 & 1055543 & HR Inc. & \\
\hline 11 & 09047700 & Keystone Gulch nr Dillon, CO & 393540 & 1055819 & DOW-RW, HR Inc., USGS & Active \\
\hline 12 & KGSW01 & Keystone Gulch stream grab 1 & 393225 & 1055603 & HR Inc. & \\
\hline 13 & KGSW02 & Keystone Gulch stream grab 2 & 393413 & 1055725 & HR Inc. & \\
\hline 14 & MZAU01 & Mozart $\mathrm{Cr}$ autosampler & 393359 & 1055711 & HR Inc. & \\
\hline 15 & MZSW01 & Mozart Cr stream grab & 393359 & 1055711 & HR Inc. & \\
\hline 16 & NT-SW-008, NT-SW-012 & National Treasury surface water & 393705.257776 & 1054738.149655 & AGS & \\
\hline 17 & NorthForkSnake & $\begin{array}{l}\text { N Fk Snake R at Montezuma Rd abv R Run } 03 \text { mi } \\
\text { abv Snake R }\end{array}$ & 393628 & 1055627 & ABSR & \\
\hline 18 & 3938001055345 & N Fk Snake R near beaver ponds & 393800.2 & 1055345.1 & INSTAAR & \\
\hline 19 & $12343 \mathrm{~A}$ & N Fk Snake R nr mouth & 393626.3 & 1055622.8 & CDPHE & \\
\hline 20 & PC-SW-05 & Peru Cr 01 mile upstream of confl with Snake R & 393549.4 & 1055222.7 & USEPA & \\
\hline 21 & PC_ 2 & Peru Creek abv Snake R & 393550.89 & 1055213.678 & CSU-FWB & \\
\hline 22 & PC-SW-03 & $\begin{array}{l}\text { Peru Creek at gravesite below the confluence with } \\
\text { Cinnamon Gulch }\end{array}$ & 393557.516 & 1054955.596 & USEPA & \\
\hline 23 & 12344 & Peru Cr at mouth & 393533 & 1055219 & CDPHE & \\
\hline 24 & 393557105512400 & Peru Cr at mouth nr Montezuma, $\mathrm{CO}$ & 393557 & 1055124 & USEPA, USGS & \\
\hline 25 & 767 & Peru Cr at Peru Cr blw FR 214 & 393557 & 1055127 & DOW-RW & \\
\hline 226 & $12344 \mathrm{~A} 3$ & Peru Cr blw Pennsylvania Mine nr Keystone & 393603.99996 & 1054856.00016 & CDPHE & \\
\hline 227 & SM-SW-015B & Peru Creek below Shoe Basin input (high flow sample site) & 393619.361524 & 1054801.318510 & AGS & \\
\hline 28 & EPA-PC4, PC-SW-02B & Peru Cr downstream of Pennsylvania Mine & 393605 & 1054855 & USEPA & \\
\hline 29 & EPA-PC6 & Peru Cr upstream of Pennsylvania Mine & 393615 & 1054820 & USEPA & \\
\hline 230 & $\mathrm{PC} 0$ & Peru Creek 0 meters downstream of injection & 393604 & 1054841 & INSTAAR & \\
\hline 31 & PC 51 & Peru Creek 51 meters downstream of injection & 393609 & 1054842 & INSTAAR & \\
\hline 32 & PC 139 & Peru Creek 139 meters downstream of injection & 393607 & 1054845 & INSTAAR & \\
\hline
\end{tabular}


Appendix 1. Stream sites in the Blue River watershed with six or more water-quality samples or exceedances of Colorado Department of Public Health and Environment trace element water-quality standards for protection of aquatic life or domestic water supply and selected reservoir sites.-Continued

[USEPA, U.S. Environmental Protection Agency; STORET, STOrage and RETrieval database; USGS, U.S. Geological Survey; NWIS, National Water Information System; HR Inc., Hydrosphere Resource Consultants, Inc.; INSTAAR, University of Colorado Institute of Arctic and Alpine Research; CDPHE, Colorado Department of Public Health and Environment; DOW-RW, Colorado Division of Wildlife

River Watch program; AGS, American Geological Services; ABSR, Arapahoe Basin Ski Resort; CSU-FWB, Colorado State University Department of Fish, Wildlife, and Conservation Biology; NWCCOG, Northwest Colorado Council of Governments; SWQC, Summit Water Quality Committee; ABC Inc, Adrian Brown Consultants, Inc.; BSD, Breckenridge Sanitation District; CDOT, Colorado Department of Transportation; DWB, Denver Water Board. USGS streamflow-gaging stations with the listing of 'Active' are operational as of water year 2008; stations listed as 'Historic' have been discontinued. See figure 3 for location of active gages. Some stream sites with six or more water-quality samples or exceedances of standards are not listed because no latitude and longitude data were available for the sites]

\begin{tabular}{|c|c|c|c|c|c|c|}
\hline \multirow[b]{2}{*}{$\begin{array}{c}\text { Site } \\
\text { number in } \\
\text { this report } \\
\text { (fig. 5) }\end{array}$} & \multicolumn{6}{|c|}{ Information from USEPA STORET and USGS NWIS } \\
\hline & $\begin{array}{l}\text { Site identification } \\
\text { number in database }\end{array}$ & Site name in database & Latitude & Longitude & Source agency & $\begin{array}{c}\text { USGS } \\
\text { streamflow- } \\
\text { gaging } \\
\text { station } \\
\end{array}$ \\
\hline \multicolumn{7}{|c|}{ Snake River subwatershed_-Continued } \\
\hline 33 & PC 251 & Peru Creek 251 meters downstream of injection & 393606 & 1054849 & INSTAAR & \\
\hline 34 & PC 485 & Peru Creek 485 meters downstream of injection & 393605 & 1054856 & INSTAAR & \\
\hline 35 & PC 583 & Peru Creek 583 meters downstream of injection & 393605 & 1054900 & INSTAAR & \\
\hline 36 & PC 824 & Peru Creek 824 meters downstream of injection & 393604 & 1054907 & INSTAAR & \\
\hline 37 & PC 908 & Peru Creek 908 meters downstream of injection & 393604 & 1054910 & INSTAAR & \\
\hline 38 & PC 60 Trib & Peru Creek Tributary 60 meters downstream of injection & 393608 & 1054842 & INSTAAR & \\
\hline 39 & PC 530 Trib & Peru Creek Tributary 530 meters downstream of injection & 393606 & 1054858 & INSTAAR & \\
\hline 40 & PV-SW-013 & Peruvian surface water & 393656.8 & 1054737.3 & AGS & \\
\hline 41 & 12345 & Saints John Cr at Montezuma & 393455 & 1055218 & CDPHE, USEPA & \\
\hline 42 & SB-DW-039, SB-DW-040 & Shoe Basin ditch water & 393626.739 & 1054754.4 & AGS & \\
\hline 43 & SB-SW-014, SB-SW-041 & Shoe Basin surface water & 393642.597 & 1054740.952 & AGS & \\
\hline 44 & RIVRUNabvNFORKSNAKE & Snake R $300 \mathrm{ft}$ abv North Fk & 393617 & 1055631 & ABSR & \\
\hline 45 & SN2 & Snake R abv confl with Deer $\mathrm{Cr}$ & 393350 & 1055136 & CDPHE, INSTAAR, USEPA & \\
\hline 46 & 12349 & Snake R abv Deer Cr abv Montezuma & 393349 & 1055138 & CDPHE & \\
\hline 47 & SRL & Snake $\mathrm{R}$ abv inlet to Dillon Reservoir & 393608 & 1055948 & NWCCOG, SWQC & \\
\hline 48 & 12343 & Snake R abv Keystone & 393621 & 1055629 & CDPHE & \\
\hline 49 & SR_1 & Snake $\mathrm{R}$ abv Peru $\mathrm{Cr}$ & 393540.6 & 1055219.9 & CSU-FWB & \\
\hline 50 & KeyCondoblwNFork & $\begin{array}{l}\text { Snake R at Keystone Condos } 075 \text { mi blw North Fk, } \\
\text { blw bridge }\end{array}$ & 393622 & 1055648 & ABSR & \\
\hline 51 & 52 & Snake $\mathrm{R}$ at $\mathrm{KSS} \mathrm{Br}$ & 393605 & 1055944 & DOW-RW & \\
\hline 52 & 12346 & Snake R at Montezuma & 393514 & 1055204 & CDPHE & \\
\hline 53 & 51 & $\begin{array}{l}\text { Snake R above confluence with Keystone Gulch (original } \\
\text { site name in database: Snake R at Snake confl) }\end{array}$ & 393612 & 1055836 & DOW-RW & \\
\hline 54 & 393606105594600 & Snake R blw Keystone, CO & 393606 & 1055946 & CDPHE, USGS & \\
\hline 55 & 393557105530000 & Snake R blw mouth of Peru Cr & 393557 & 1055300 & USEPA, USGS & \\
\hline 56 & SR-SW-02A & Snake R downstream of confl with Peru $\mathrm{Cr}$ & 393552 & 1055229.6 & USEPA & \\
\hline 57 & SR-SW-03 & Snake R downstream sample - just before Dillon Reservoir & 393620.2 & 1060033.5 & USEPA & \\
\hline 58 & SR-SW-01 & Snake R just before confl with Peru Cr, background & 393546.8 & 1055225.1 & USEPA & \\
\hline 59 & SR-SW-02B & Snake R just blw confl with Thurman Gulch & 393557 & 1055259.5 & USEPA & \\
\hline 60 & 09047500 & Snake R nr Montezuma, CO & 393620 & 1055633 & USGS & Active \\
\hline 61 & SR-Site11-0 & Snake R Sr-Site11-0 & 393217 & 1055025 & INSTAAR & \\
\hline 62 & SR-Site1-2250 & Snake R Sr-Site1-2250 & 393323 & 1055044 & INSTAAR & \\
\hline 63 & SRSW01 & Snake R stream grab 1 (snowmaking intake) & 393624 & 1055707 & HR Inc. & \\
\hline 64 & EPA-39353010521 & Snake R upstream of Peru Cr confl & 393525 & 1055216 & USEPA & \\
\hline
\end{tabular}

Snake $\mathrm{R}$ at $\mathrm{KSS} \mathrm{Br}$

Snake R at Montezuma

site name in dabase: Snake $\mathrm{R}$ at Snake confl)

Snake R blw Keystone, $\mathrm{CO}$ 
Appendix 1. Stream sites in the Blue River watershed with six or more water-quality samples or exceedances of Colorado Department of Public Health and Environment trace element water-quality standards for protection of aquatic life or domestic water supply and selected reservoir sites.-Continued

[USEPA, U.S. Environmental Protection Agency; STORET, STOrage and RETrieval database; USGS, U.S. Geological Survey; NWIS, National Water Information System; HR Inc., Hydrosphere Resource Consultants, Inc.; INSTAAR, University of Colorado Institute of Arctic and Alpine Research; CDPHE, Colorado Department of Public Health and Environment; DOW-RW, Colorado Division of Wildlife River Watch program; AGS, American Geological Services; ABSR, Arapahoe Basin Ski Resort; CSU-FWB, Colorado State University Department of Fish, Wildlife, and Conservation Biology; NWCCOG, Northwest Colorado Council of Governments; SWQC, Summit Water Quality Committee; ABC Inc, Adrian Brown Consultants, Inc.; BSD, Breckenridge Sanitation District; CDOT, Colorado Department of Transportation; DWB, Denver Water Board. USGS streamflow-gaging stations with the listing of 'Active' are operational as of water year 2008; stations listed as 'Historic' have been discontinued. See figure 3 for location of active gages. Some stream sites with six or more water-quality samples or exceedances of standards are not listed because no latitude and longitude data were available for the sites]

\begin{tabular}{|c|c|c|c|c|c|c|}
\hline \multirow[b]{2}{*}{$\begin{array}{c}\text { Site } \\
\text { number in } \\
\text { this report } \\
\text { (fig. 5) }\end{array}$} & \multicolumn{6}{|c|}{ Information from USEPA STORET and USGS NWIS } \\
\hline & $\begin{array}{l}\text { Site identification } \\
\text { number in database }\end{array}$ & Site name in database & Latitude & Longitude & Source agency & $\begin{array}{c}\text { USGS } \\
\text { streamflow- } \\
\text { gaging } \\
\text { station } \\
\end{array}$ \\
\hline \multicolumn{7}{|c|}{ Snake River subwatershed -Continued } \\
\hline 65 & 3935571055357 & Snake River above North Fork Snake River & 393557.3 & 1055357.8 & INSTARR & \\
\hline 66 & 3936241055709 & Snake River below North Fork Snake River & 393624.1 & 1055709.7 & INSTARR & \\
\hline 67 & SCL & Soda $\mathrm{Cr}$ at inlet to weir in pond abv Swan Mountain Road & 393602 & 1060057 & NWCCOG, SWQC & \\
\hline 68 & 393552106004700 & Soda $\mathrm{Cr}$ at mouth nr Dillon, $\mathrm{CO}$ & 393552 & 1060047 & USGS & \\
\hline 69 & 12370 & Soda Cr downstream Snake R WWTP & 393558.6 & 1060049.20012 & CDPHE & \\
\hline 70 & $\begin{array}{l}\text { SP-SW-032, SP-SW-033, } \\
\text { SP-SW-037, SP-SW-038 }\end{array}$ & South Paymaster surface water & 393700.121714 & 1054758.642302 & AGS & \\
\hline \multicolumn{7}{|c|}{ Upper Blue River subwatershed } \\
\hline 71 & BR_4 & Blue R 4 miles downstream of Breckenridge, $\mathrm{CO}$ & 393224.5 & 1060229.5 & CSU-FWB & \\
\hline 72 & $654^{-}$ & $\begin{array}{l}\text { Blue } \mathrm{R} \text { abv Breck and Hwy } 9 \text { Bridge and blw Goose } \\
\text { Pasture Tarn }\end{array}$ & 392740 & 1060210 & DOW-RW & \\
\hline 73 & BR-5 & Blue R abv confl Dillon Res & 393400 & 1060257 & ABC Inc., USEPA & \\
\hline 74 & 000115 & Blue R abv Dillon Res & 393400 & 1060300 & CDPHE & \\
\hline 75 & BR-1 & Blue R abv French Gulch & 392937 & 1060246 & ABC Inc. & \\
\hline 76 & $\mathrm{BR}$ & Blue R abv Iowa Hill Sanitation District & ${ }^{1392952.28}$ & ${ }^{1} 1060249.92$ & BSD & \\
\hline 77 & 655 & Blue R abv N Park Ave Bridge & 392903 & 1060249 & DOW-RW & \\
\hline 278 & 12305 & Blue $\mathrm{R}$ abv Town of Blue $\mathrm{R}$ & 392743 & 1060409 & CDPHE & \\
\hline 79 & 09046490 & Blue $\mathrm{R}$ at Blue $\mathrm{R}, \mathrm{CO}$ & 392721 & 1060152 & NWCCOG, SWQC, USGS & Active \\
\hline 80 & 393057106025800 & Blue R at Coyne Valley Rd nr Breckenridge, CO & 393057 & 1060258 & $\begin{array}{l}\text { DOW-RW, NWCCOG, } \\
\text { USEPA, USGS }\end{array}$ & \\
\hline 81 & 179 & Blue $\mathrm{R}$ at French Gulch & 392943 & 1060245 & DOW-RW & \\
\hline 82 & 177 & Blue R at Gold Hill & 393223 & 1060227 & DOW-RW & \\
\hline 83 & 657 & Blue R at Hwy 9 abv Swan R & 393222 & 1060233 & $\begin{array}{l}\text { ABC Inc., DOW-RW, NWC- } \\
\text { COG, USEPA }\end{array}$ & \\
\hline 84 & 392947106024500 & Blue R blw French Gulch nr Breckenridge, CO & 392947 & 1060245 & ABC Inc., USGS & \\
\hline 85 & 392944106024400 & Blue R nr Breckenridge nr Cty Rd 3 & 392944 & 1060244 & $\begin{array}{c}\text { DOW-RW, NWCCOG, } \\
\text { USGS }\end{array}$ & \\
\hline 86 & 09046600 & Blue R nr Dillon, CO & 393400 & 1060256 & $\begin{array}{l}\text { CDPHE, NWCCOG, SWQC, } \\
\text { USEPA, USGS }\end{array}$ & Active \\
\hline 87 & FC_2 & French Creek above Blue River & 392852.842 & 1060109.02568 & CSU-FWB & \\
\hline 88 & FG-5.5 & French Gulch & 392850 & 1060103 & ABC Inc. & \\
\hline 89 & FG-8 & French Gulch abv confl w Dead Elk Pond & 392906 & 1060144 & ABC Inc., USEPA & \\
\hline 90 & 392907106013900 & French Gulch abv Gibson Gulch & 392907 & 1060139 & ABC Inc., USGS & \\
\hline
\end{tabular}


Appendix 1. Stream sites in the Blue River watershed with six or more water-quality samples or exceedances of Colorado Department of Public Health and Environment trace element water-quality standards for protection of aquatic life or domestic water supply and selected reservoir sites.-Continued

[USEPA, U.S. Environmental Protection Agency; STORET, STOrage and RETrieval database; USGS, U.S. Geological Survey; NWIS, National Water Information System; HR Inc., Hydrosphere Resource Consultants, Inc.; INSTAAR, University of Colorado Institute of Arctic and Alpine Research; CDPHE, Colorado Department of Public Health and Environment; DOW-RW, Colorado Division of Wildlife

River Watch program; AGS, American Geological Services; ABSR, Arapahoe Basin Ski Resort; CSU-FWB, Colorado State University Department of Fish, Wildlife, and Conservation Biology; NWCCOG, Northwest Colorado Council of Governments; SWQC, Summit Water Quality Committee; ABC Inc, Adrian Brown Consultants, Inc.; BSD, Breckenridge Sanitation District; CDOT, Colorado Department of Transportation; DWB, Denver Water Board. USGS streamflow-gaging stations with the listing of 'Active' are operational as of water year 2008; stations listed as 'Historic' have been discontinued. See figure 3 for location of active gages. Some stream sites with six or more water-quality samples or exceedances of standards are not listed because no latitude and longitude data were available for the sites]

\begin{tabular}{|c|c|c|c|c|c|c|}
\hline \multirow[b]{2}{*}{$\begin{array}{c}\text { Site } \\
\text { number in } \\
\text { this report } \\
\text { (fig. 5) }\end{array}$} & \multicolumn{6}{|c|}{ Information from USEPA STORET and USGS NWIS } \\
\hline & $\begin{array}{l}\text { Site identification } \\
\text { number in database }\end{array}$ & Site name in database & Latitude & Longitude & Source agency & $\begin{array}{c}\text { USGS } \\
\text { streamflow- } \\
\text { gaging } \\
\text { station }\end{array}$ \\
\hline \multicolumn{7}{|c|}{ Upper Blue River subwatershed-Continued } \\
\hline 91 & 392908105583600 & French Gulch abv Rich Gulch nr Lincoln, CO & 392908 & 1055836 & ABC Inc., USGS & \\
\hline 92 & FG-5 & French Gulch abv Wellington Mine & 392859 & 1060048 & ABC Inc., USEPA & \\
\hline 93 & 09046530 & French Gulch at Breckenridge, $\mathrm{CO}$ & 392935 & 1060239 & ABC Inc., USEPA, USGS & Historic $^{3}$ \\
\hline 94 & 12364 & Illinois Gulch at Breckenridge Ice Rink & 392819 & 1060220.00004 & CDPHE & \\
\hline 95 & 393040106031700 & South Barton Gulch at mouth nr Breckenridge, $\mathrm{CO}$ & 393040 & 1060317 & NWCCOG, USGS & \\
\hline 96 & FG-6D & Tributary to mine drain ditch above confluence & 392852 & 1060108 & $\mathrm{ABC}$ Inc. & \\
\hline \multicolumn{7}{|c|}{ Tenmile Creek subwatershed } \\
\hline 97 & 12336 & Ten Mile Cr abv Wheeler Junction nr Copper Mountain & 393014.5 & 1060819.89996 & CDPHE & \\
\hline 98 & TM-2 & Tenmile $\mathrm{Cr}$ abv Frisco & 393431 & 1060636 & CDOT & \\
\hline 99 & TM-1 & Tenmile $\mathrm{Cr}$ abv West $\mathrm{Fk}$ & 393036 & 1060828 & CDOT & \\
\hline 100 & 393440106055300 & Tenmile $\mathrm{Cr}$ at 4 th Street at Frisco, $\mathrm{CO}$ & 393440 & 1060553 & USGS & \\
\hline 101 & 000141 & Tenmile $\mathrm{Cr}$ at Frisco & 393446 & 1060532 & CDPHE, NWCCOG, SWQC & Historic $^{4}$ \\
\hline 102 & 281 & Tenmile $\mathrm{Cr}$ at inlet & 393440 & 1060557 & DOW-RW & \\
\hline 103 & 392529106111000 & Tenmile Creek at Kokomo, CO & 392529 & 1061110 & CDPHE, USEPA, USGS & \\
\hline 104 & 09050100 & Tenmile Cr blw North Tenmile C, at Frisco, CO & 393431 & 1060636 & NWCCOG, SWQC, USGS & Active \\
\hline 105 & WTM2 & West Tenmile Cr abv Copper Mountain & 393035 & 1060829 & CDOT & \\
\hline 106 & 09049260 & West Tenmile Cr abv Wheeler Gulch at Copper Mtn & 393005 & 1060904 & USGS & \\
\hline 107 & 09049200 & West Tenmile $\mathrm{Cr}$ at Copper Mountain, $\mathrm{CO}$ & 393004 & 1061004 & CDPHE, USGS & Historic $^{5}$ \\
\hline${ }^{2} 108$ & 12338,12339 & West Tenmile Cr at Shrine Pass & 393000 & 1061000 & CDPHE & \\
\hline${ }^{2} 109$ & 12337 & West Tenmile Cr blw Copper & 392500 & 1060900 & CDPHE & \\
\hline \multicolumn{7}{|c|}{ Lower Blue River watershed } \\
\hline 110 & 178 & Blue $\mathrm{R}$ at Bushee $\mathrm{Cr}$ & 394029 & 1060530 & DOW-RW & \\
\hline 111 & 12300 & Blue R at City Road 1 & 400143.8 & 1062312.9 & CDPHE & \\
\hline 112 & 12301 & Blue $\mathrm{R}$ at Grand $\mathrm{Cr} 10$ Bridge & 395523.1 & 1062050.1 & CDPHE & \\
\hline 113 & $\mathrm{BR} 3$ & Blue R at inlet to Green Mountain Reservoir & 394936 & 1061255 & NWCCOG, SWQC & \\
\hline 114 & 251 & Blue R at Knorr & 395524 & 1062051 & DOW-RW & \\
\hline 115 & 196 & Blue $\mathrm{R}$ at Straight $\mathrm{Cr}$ & 393746 & 1060417 & DOW-RW & \\
\hline 116 & 252 & Blue $\mathrm{R}$ at Trough & 400145 & 1062312 & DOW-RW & \\
\hline${ }^{2} 117$ & 000098 & Blue R blw Dillon Res & 394500 & 1060900 & CDPHE & \\
\hline 118 & 09050700 & Blue R blw Dillon, CO & 393732 & 1060357 & NWCCOG, SWQC, USGS & Active \\
\hline 119 & 09057500 & Blue R blw Green Mountain Reservoir, CO & 395249 & 1062000 & NWCCOG, SWQC, USGS & Active \\
\hline 120 & BR6 & Blue R blw Silverthorne, abv Bushee Cr & 394028 & 1060532 & NWCCOG, SWQC & \\
\hline 121 & 12304 & Blue R downstream Dillon Reservoir and Straight $\mathrm{Cr}$ & 393731.7 & 1060359 & CDPHE & \\
\hline 122 & 12302 & Blue R downstream Green Mtn Reservoir & 395248.8 & 1062002.7 & CDPHE & \\
\hline
\end{tabular}


Appendix 1. Stream sites in the Blue River watershed with six or more water-quality samples or exceedances of Colorado Department of Public Health and Environment trace element water-quality standards for protection of aquatic life or domestic water supply and selected reservoir sites.-Continued

[USEPA, U.S. Environmental Protection Agency; STORET, STOrage and RETrieval database; USGS, U.S. Geological Survey; NWIS, National Water Information System; HR Inc., Hydrosphere Resource Consultants, Inc.; INSTAAR, University of Colorado Institute of Arctic and Alpine Research; CDPHE, Colorado Department of Public Health and Environment; DOW-RW, Colorado Division of Wildlife River Watch program; AGS, American Geological Services; ABSR, Arapahoe Basin Ski Resort; CSU-FWB, Colorado State University Department of Fish, Wildlife, and Conservation Biology; NWCCOG, Northwest Colorado Council of Governments; SWQC, Summit Water Quality Committee; ABC Inc, Adrian Brown Consultants, Inc.; BSD, Breckenridge Sanitation District; CDOT, Colorado Department of Transportation; DWB, Denver Water Board. USGS streamflow-gaging stations with the listing of 'Active' are operational as of water year 2008; stations listed as 'Historic' have been discontinued. See figure 3 for location of active gages. Some stream sites with six or more water-quality samples or exceedances of standards are not listed because no latitude and longitude data were available for the sites]

\begin{tabular}{|c|c|c|c|c|c|c|}
\hline \multirow[b]{2}{*}{$\begin{array}{c}\text { Site } \\
\text { number in } \\
\text { this report } \\
\text { (fig. 5) }\end{array}$} & \multicolumn{6}{|c|}{ Information from USEPA STORET and USGS NWIS } \\
\hline & $\begin{array}{l}\text { Site identification } \\
\text { number in database }\end{array}$ & Site name in database & Latitude & Longitude & Source agency & $\begin{array}{c}\text { USGS } \\
\text { streamflow- } \\
\text { gaging } \\
\text { station }\end{array}$ \\
\hline \multicolumn{7}{|c|}{ Lower Blue River watershed-Continued } \\
\hline 123 & 09052000 & Rock Cr nr Dillon, CO & 394323 & 1060741 & USGS & Historic $^{6}$ \\
\hline 124 & 12373 & Spruce $\mathrm{Cr}$ at $\mathrm{CR} 10$ & 395524 & 1062430.3 & CDPHE & \\
\hline 125 & WS-BL-006 & Straight Cr 1.3 miles abv diversion structure & 393913 & 1055942 & DWB & \\
\hline 126 & $\mathrm{SC} 1$ & Straight $\mathrm{Cr}$ abv Dillon Basin & 393840.6 & 1060042.7 & CDOT & \\
\hline${ }^{2} 127$ & $\mathrm{SC}-2$ & Straight $\mathrm{Cr}$ abv Silverthorne & 393833 & 1060223 & CDOT & \\
\hline${ }^{2} 128$ & 12322 & Straight $\mathrm{Cr}$ abv the Town of Dillon & 393828 & 1060222 & CDPHE & \\
\hline 129 & 393736106040200 & Straight $\mathrm{Cr}$ at mouth nr Frisco & 393736 & 1060402 & NWCCOG, SWQC & \\
\hline 130 & WS-BL-007 & Straight $\mathrm{Cr}$ blw diversion structure & 393848.1 & 1060122.8 & DWB & \\
\hline 131 & 09051050 & Straight Cr blw Laskey Gulch nr Dillon, CO & 393823 & 1060223 & CDPHE, USGS & Active \\
\hline \multicolumn{7}{|c|}{ Dillon Reservoir } \\
\hline 132 & 3935531060316 & Dillon Reservoir at Blue R arm & 393553 & 1060316 & SWQC & \\
\hline 133 & 3937071060255 & Dillon Reservoir at Snake R arm & 393707 & 1060255 & SWQC & \\
\hline 134 & 3936061060346 & Dillon Reservoir at Tenmile Cr arm & 393606 & 1060346 & SWQC & \\
\hline 135 & 3937161060332 & Dillon Reservoir nr Dam (west) & 393716 & 1060332 & SWQC & \\
\hline${ }^{2} 136$ & 002401 & So Plat Dillon Res at outlet & 393930 & 1060330 & DWB & \\
\hline \multicolumn{7}{|c|}{ Green Mountain Reservoir } \\
\hline 137 & 3952391061859 & Green Mountain Reservoir between Heeney and dam & 395239 & 1061859 & SWQC & \\
\hline 138 & 3951331061530 & Green Mnt Reservoir site GA & 395133 & 1061530 & SWQC & \\
\hline 139 & 3952081061652 & Green Mnt Reservoir site GB & 395208 & 1061652 & SWQC & \\
\hline 140 & 3952371061809 & Green Mnt Reservoir site GC & 395237 & 1061809 & SWQC & \\
\hline
\end{tabular}

${ }^{1}$ Approximate location.

${ }^{2}$ Site location on figure 5 is approximated. Site location based on available latitude and longitude data did not plot near stream or water body.

${ }^{3}$ Water (WY) 1996-2005. Water year is a 12-month period beginning October 1 and ending September 30 of the following year. It is designated as the year in which it ends.

${ }^{4}$ WY $1943-1950$

${ }^{5}$ WY $1974-1979$

${ }^{6}$ WY 1943-1994. 
Appendix 2. Streamflow-gaging stations in the Blue River watershed not included in the Blue River watershed water-quality database, water year 1904 through 2010.

[USGS, U.S. Geological Survey. Information from the USGS National Water Information System (NWIS). See figure 3 for location of streamflow-gaging stations]

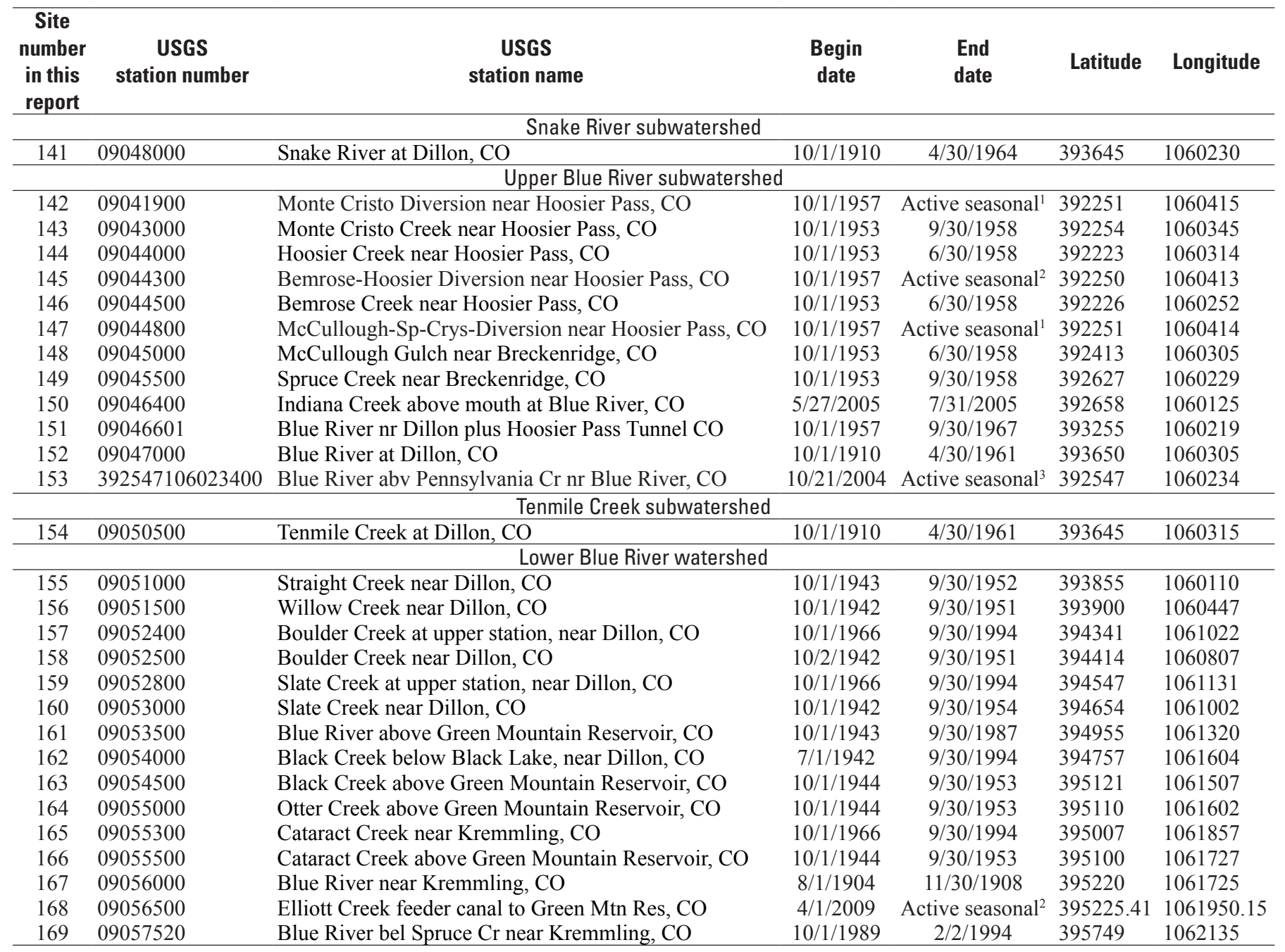

${ }^{1}$ Site is operated seasonally as of water year 2010, April through October only.

${ }^{2}$ Site is operated seasonally as of water year 2010, April through September only.

${ }^{3}$ Site is operated seasonally as of water year 2010 , October and November only. 
Appendix 3. Number of surface-water-quality samples for physical properties, major ions, nutrients, trace elements, suspended sediment, and coliform bacteria for the Snake River, upper Blue River, and Tenmile Creek subwatersheds and the lower Blue River watershed by source agency, Blue River watershed, Colorado, October 1995 through December 2006.

[SRSW, Snake River subwatershed; UBRSW, upper Blue River subwatershed; TCSW, Tenmile Creek subwatershed; LBRW, lower Blue River watershed; ABC Inc, Adrian Brown Consultants, Inc.; --, no samples; ABSR, Arapahoe Basin Ski Resort; AGS, American Geological Services; BSD, Breckenridge Sanitation District; CDOT, Colorado Department of Transportation; CDPHE, Colorado Department of Public Health and Environment; CSU-FWB, Colorado State University Department of Fish, Wildlife, and Conservation Biology; DOW-RW, Colorado Division of Wildlife River Watch program; DWB, Denver Water Board; HR Inc, Hydrosphere Resource Consultants, Inc.; INSTAAR, University of Colorado Institute of Arctic and Alpine Research; NWCCOG, Northwest Colorado Council of Governments; SWQC, Summit Water Quality Committee; USEPA, U.S. Environmental Protection Agency; USGS, U.S. Geological Survey]

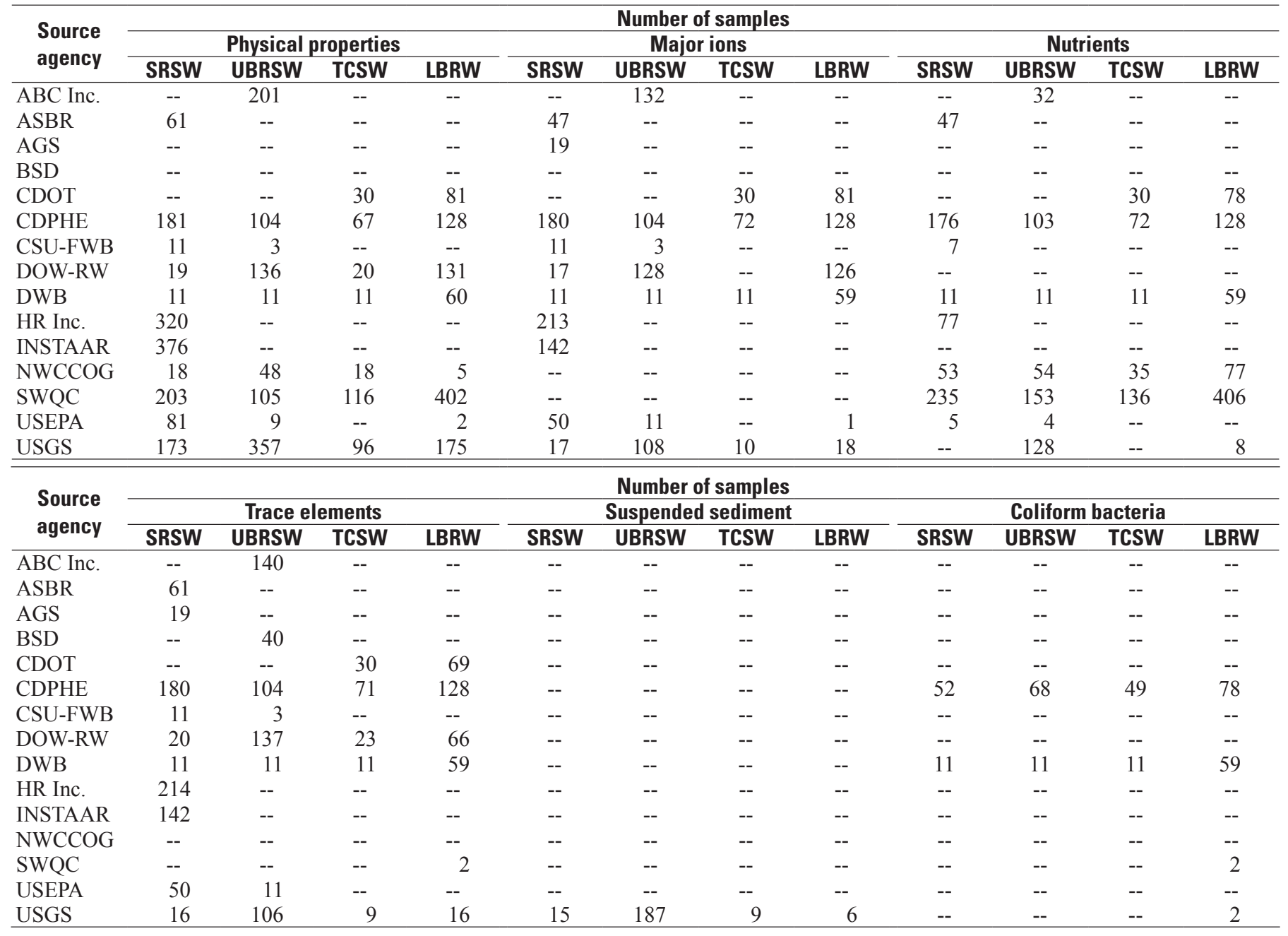


Appendix 4. U.S. Environmental Protection Agency STORET edit-checking procedure of low and high values for selected water-quality parameters in the Blue River watershed water-quality database.

[STORET, STOrage and RETrieval; ${ }^{\circ} \mathrm{C}$, degrees Celsius; ${ }^{\circ} \mathrm{F}$, degrees Fahrenheit; in., inches; $\mu \mathrm{S} / \mathrm{cm}$ at ${ }^{\circ} \mathrm{C}$, microsiemens per centimeter at 25 degrees Celsius; $\mathrm{mg} / \mathrm{L}$, milligrams per liter; $\mathrm{CaCO}_{3}$, calcium carbonate; $\mathrm{HCO}_{3}^{-}$, bicarbonate; $\mathrm{N}$, nitrogen; $\mathrm{PO}_{4}$, phosphate; $\mathrm{P}$, phosphorus; $\mu \mathrm{g} / \mathrm{L}$, micrograms per liter; col/100 mL, colonies per 100 milliliters. Parameter codes are from the USEPA STORET Data Warehouse. Data are from U.S. Environmental Protection Agency (1977)]

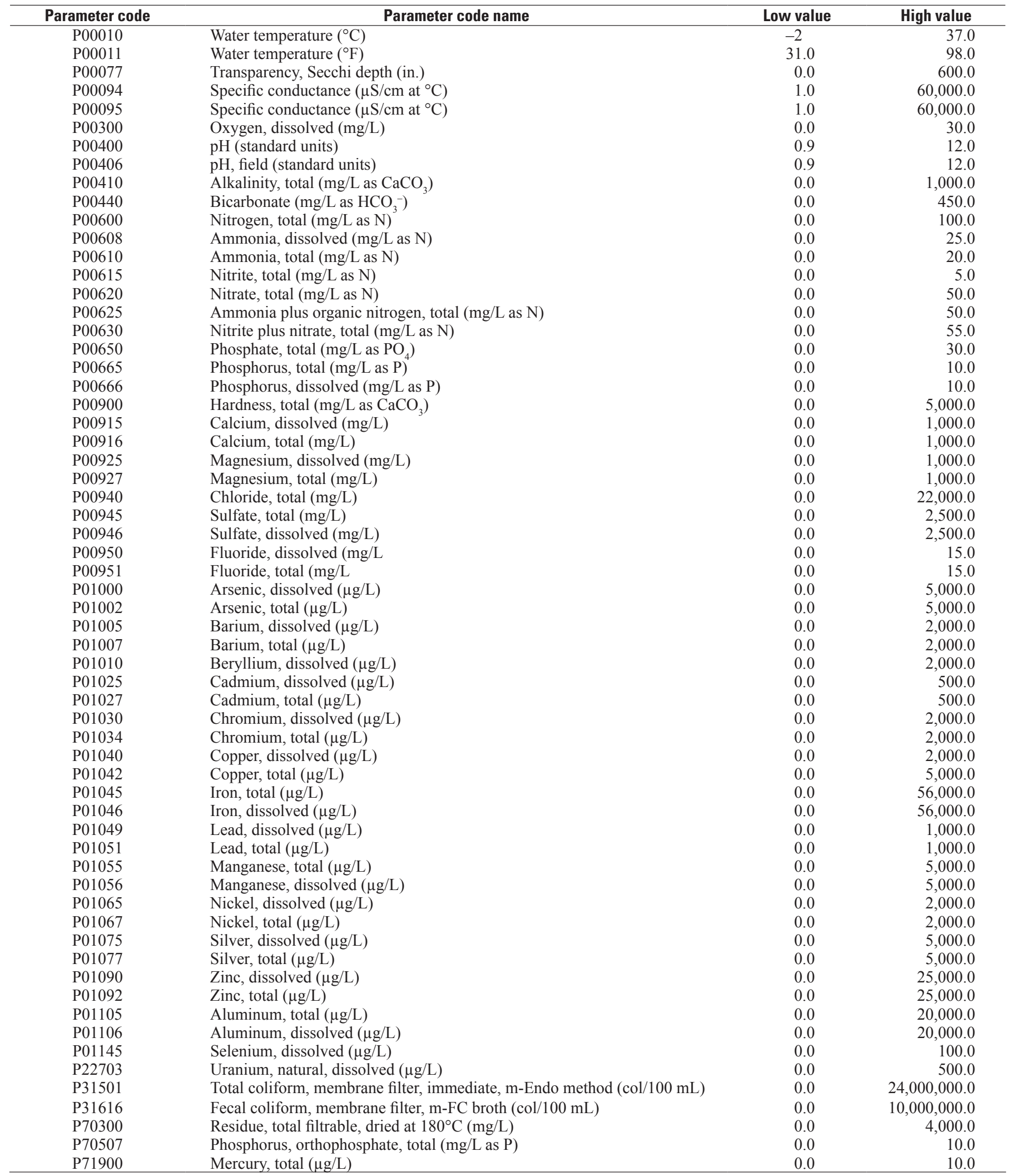


Publishing support provided by:

Denver Publishing Service Center, Denver, Colorado

For more information concerning this publication, contact: Director, USGS Colorado Water Science Center

Box 25046, Mail Stop 415

Denver, CO 80225

(303) 236-4882

Or visit the Colorado Water Science Center Web site at: http://co.water.usgs.gov/

This publication is available online at: http://dx.doi.org/10.3133/sir20135129 


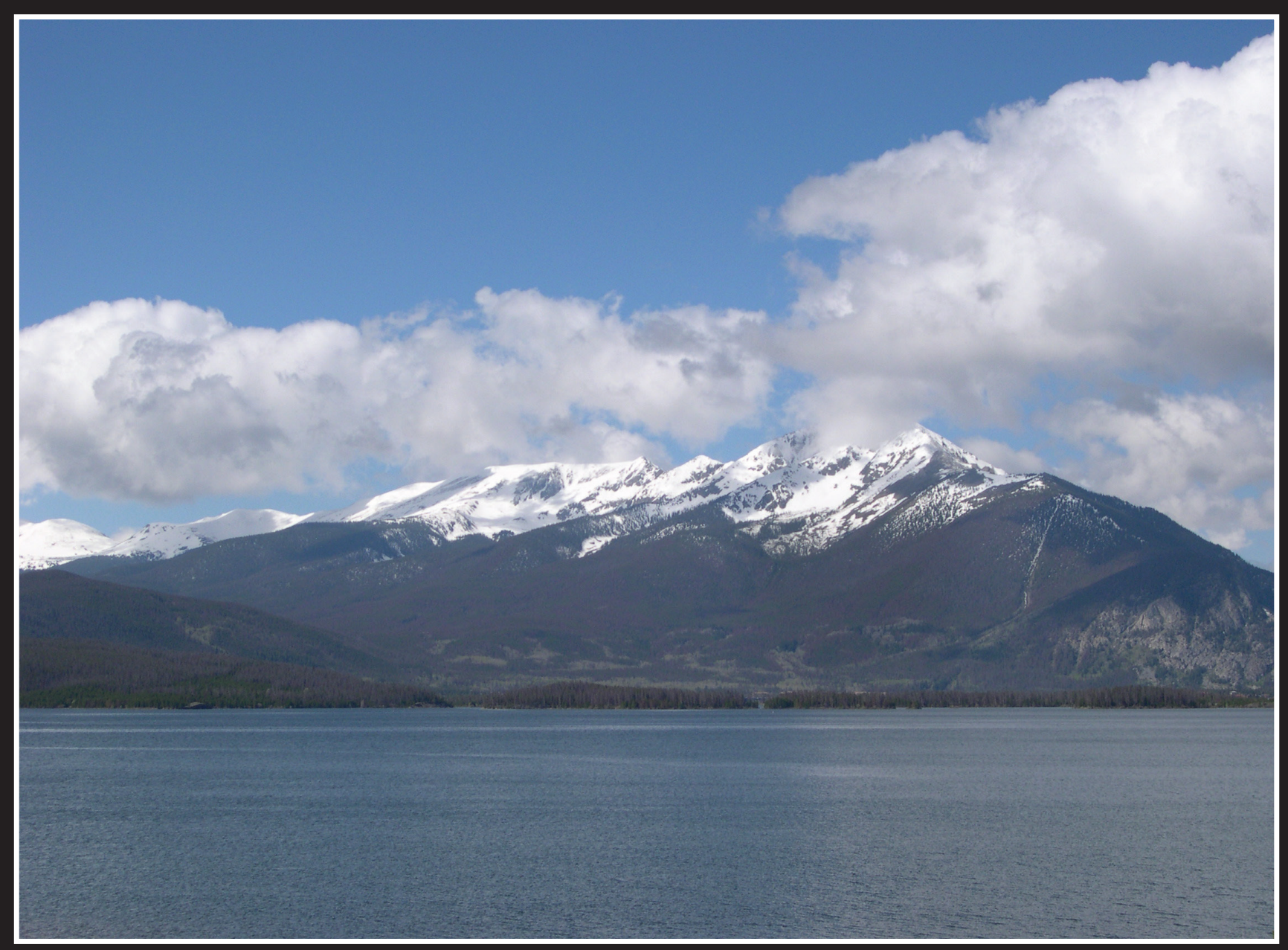

